\title{
RESULTS AND INTERPRETATION OF PRELIMINARY AQUIFER TESTS IN BOREHOLES UE-25c \#1, UE-25c \#2, AND UE-25c \#3, YUCCA MOUNTAIN, NYE COUNTY, NEVADA
}

U.S. GEOLOGICAL SURVEY

Water-Resources Investigations Report 94-4177

\section{RECEIVED \\ JUL 291996 \\ O\&TI}

Prepared in cooperation with the U.S. DEPARTMENT OF ENERGY, NEVADA FIELD OFFICE, under Interagency Agreement DE-AI08-92NV10874
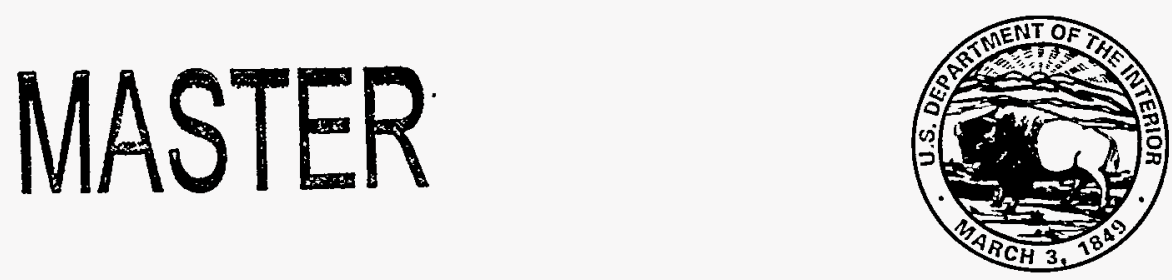



\title{
RESULTS AND INTERPRETATION OF PRELIMINARY AQUIFER TESTS IN BOREHOLES UE-25c \#1, UE-25c \#2, AND UE-25c \#3, YUCCA MOUNTAIN, NYE COUNTY, NEVADA
}

\author{
by Arthur L. Geldon
}

U.S. GEOLOGICAL SURVEY

Water-Resources Investigations Report 94-4177

Prepared in cooperation with the

U.S. DEPARTMENT OF ENERGY,

NEVADA FIELD OFFICE, under

Interagency Agreement DE-AI08-92NV10874

\section{DISCLAIMER}

This report was prepared as an account of work sponsored by an agency of the United States Government. Neither the United States Government nor any agency thereof, nor any of their employees, makes any warranty, express or implied, or assumes any legal liability or responsibility for the accuracy, completeness, or usefulness of any information, apparatus, product, or process disclosed, or represents that its use would not infringe privately owned rights. Reference herein to any specific commercial product, process, or service by trade name, trademark, manufacturer, or otherwise does not necessarily constitute or imply its endorsement, recommendation, or favoring by the United States Government or any agency thereof. The views and opinions of authors expressed herein do not necessarily state or reflect those of the United States Government or any agency thereof.

Denver, Colorado 1996 


\title{
U.S. DEPARTMENT OF THE INTERIOR \\ BRUCE BABBITT, Secretary
}

\author{
U.S. GEOLOGICAL SURVEY \\ Gordon P. Eaton, Director
}

The use of trade, product, industry, or firm names is for descriptive purposes only and does not imply endorsement by the U.S. Government.

For additional information write to: Chief, Earth Science Investigations Program

Yucca Mountain Project Branch U.S. Geological Survey

Box 25046, MS 421

Denver Federal Center

Denver, CO 80225
Copies of this report can be purchased from: U.S. Geological Survey USGS Information Services Open-File Reports Section Box 25286, MS 517 Denver Federal Center Denver, CO 80225 


\section{DISCLAIMER}

Portions of this document may be illegible in electronic image products. Images are produced from the best available original document. 


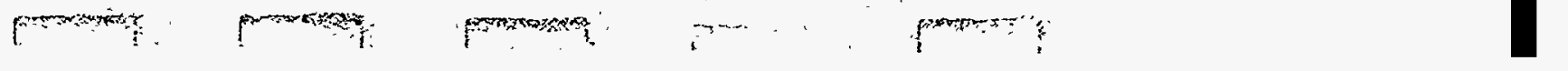




\section{CONTENTS}

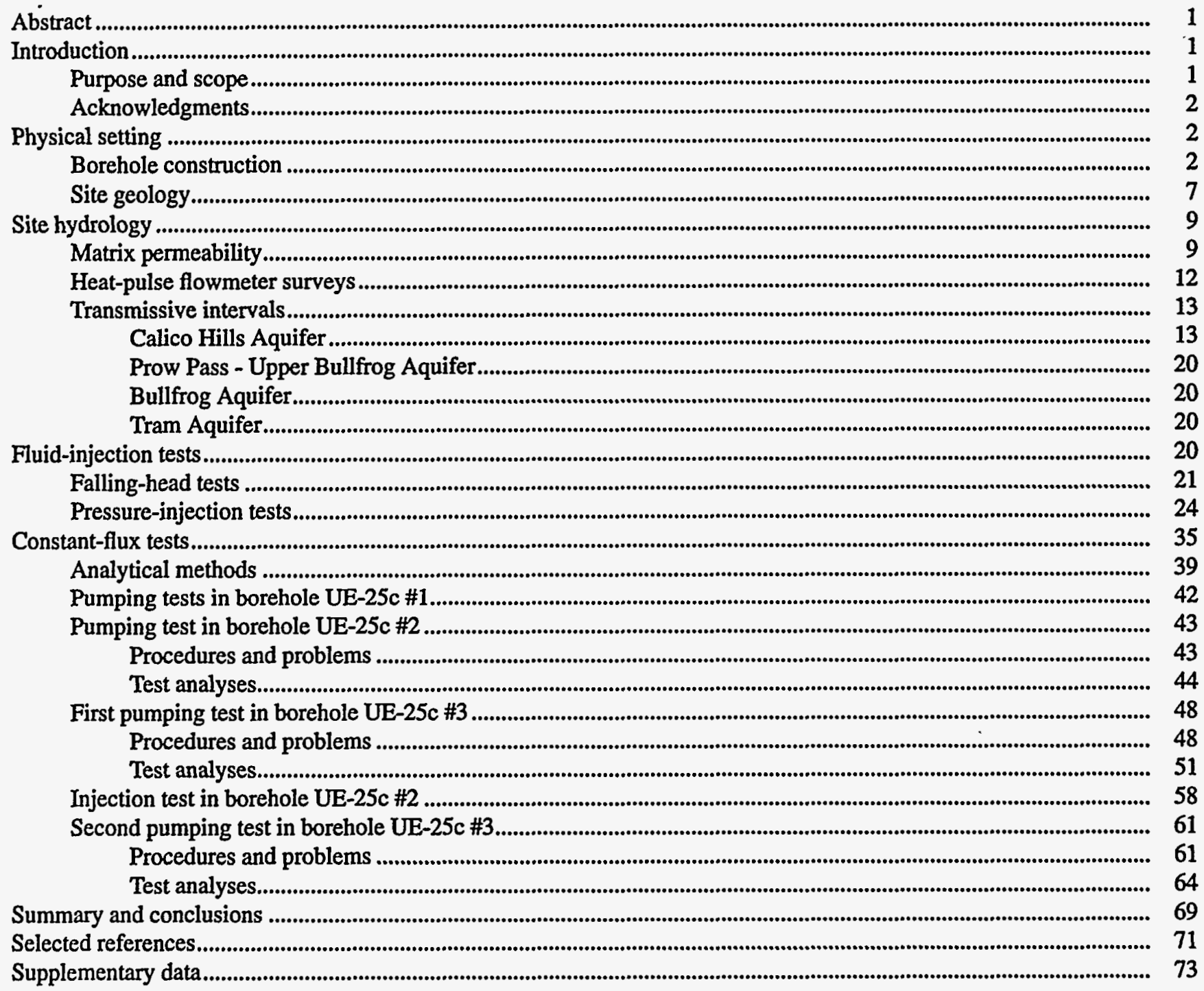

\section{PLATES}

\section{[n pocket]}

1-3. Charts showing:

1. Indicators of transmissive intervals in borehole UE-25c \#1, Yucca Mountain, Nye County, Nevada

2. Indicators of transmissive intervals in borehole UE-25c \#2, Yucca Mountain, Nye County, Nevada

3. Indicators of transmissive intervals in borehole UE-25c \#3, Yucca Mountain, Nye County, Nevada 


\section{FIGURES}

1. Map showing location of Yucca Mountain, boreholes UE-25c \#1, UE-25c \#2, and UE-25c \#3, and nearby boreholes used for hydrologic investigations

2. Map showing surface location and drift of boreholes UE-25c \#1, UE-25c \#2, and UE-25c \#3.

3. Diagram showing relation between fractures and borehole diameter in an enlarged, rugose interval of borehole UE-25c \#2 .

4-6. Plots showing:

4. Frequency distribution of fracture orientations in boreholes UE-25c \#1, UE-25c \#2, and UE-25c \#3..... 10

5. Horizontal matrix permeability in the tuffs and lavas of Calico Hills and Crater Flat Tuff, eastcentral Yucca Mountain area, as a function of depth within geologic units..

6. Relation of vertical to horizontal matrix permeability in core samples from the tuffs and lavas of Calico Hills and Crater Flat Tuff in the c-holes and nearby boreholes

7. Hydrogeologic section of the c-hole complex.

8. Sketch showing design configuration of falling-head tests in borehole UE-25c \#1, October 1983........................ 23

9-15. Plots showing:

9. Analyses of falling-head tests in borehole UE-25c \#1, October 1983, assuming an infinite, homogeneous, isotropic, confined aquifer

10. Falling-head tests and transmissivity values obtained in relation to geology, borehole UE-25c \#1

11. Analyses of pressure-injection tests conducted in borehole UE-25c \#1, October 1983, assuming an infinite, homogeneous, isotropic, confined aquifer

12. Transmissivity and hydraulic conductivity distributions within a small radius of borehole UE-25c \#1, estimated from falling-head and pressure-injection tests

13. Drawdown as a function of time in borehole UE-25c \#2 during the pumping test in borehole UE-25c \#2, March 1984

14. Drawdown as a function of time in boreholes UE-25c \#1 and UE-25p \#1 during the pumping test in borehole UE-25c \#2, March 1984

15. Atmospheric pressure at borehole USW H-4 during the pumping test in borehole UE-25c \#2, March 1984

16-29. . Plots showing:

16. Analytical solution for drawdown data from borehole UE-25c \#1 above the packers assuming a fissure-block aquifer, pumping test in borehole UE-25c \#2, March 1984.

17. Analytical solutions for drawdown and recovery data from borehole UE-25c \#1 above the packers assuming an infinite, homogeneous, anisotropic, unconfined aquifer, pumping test in borehole UE-25 c \#1, March 1984

18. Drawdown as a function of time during the pumping test in borehole UE-25c \#3, May to June 1984: (A), borehole UE-25c \#3; (B), borehole UE-25c \#2 .

19. Drawdown as a function of time in borehole UE-25c \#1 during the pumping test in borehole UE-25c \#3, May to June 1984: (A), above the packers; (B), between the packers.

20. Analytical solution for residual drawdown data from borehole UE-25c \#3 assuming an infinite,

20. Analytical solution for residual drawdown data from borehole UE-25c \#3 assuming an infinite,

21. Analytical solution for drawdown data from borehole UE-25c \#3 assuming an infinite, homogeneous, isotropic, confined aquifer with leakage from a confining unit without storage, pumping test in

borehole UE-25c \#3, May to June 1984.

22. Analytical solution for drawdown data from borehole UE-25c \#2 assuming a fissure-block aquifer, pumping test in borehole UE-25c \#3, May to June 1984

23. Analytical solution for drawdown data from borehole UE-25c \#2 assuming an infinite, homogeneous,

23. Analytical solution for drawdown data from borehole UE-25c \#2 assuming an infinite, ho
anisotropic, unconfined aquifer, pumping test in borehole UE-25c \#3, May to June 1984 .

infinite, homogeneous, anisotropic, unconfined aquifer, pumping test in borehole UE-25c \#3, May to June 1984.

25. Analytical solution for recovery data from borehole UE-25c \#1 between the packers assuming an infinite, homogeneous, anisotropic, unconfined aquifer, pumping test in borehole UE-25c \#3, May to June 1984. 
26. Water-level changes in borehole UE-25c \#2 during and after injection of water between packers on October 30, 1984

27. Water-level changes in boreholes UE-25c \#1 and UE-25c \#3 in response to injection of water into borehole UE-25c \#2, October 30, 1984

28. Atmospheric pressure at borehole USW H-4 during the pumping test in borehole UE-25c \#3, October to December 1984.

29. Drawdown as a function of time in borehole UE-25c \#3 during the pumping test in borehole UE-25c \#3, October to December 1984

30-35. Plots showing:

30. Drawdown as a function of time in borehole UE-25c \#1 during the pumping test in borehole UE-25c \#3, October to December 1984

31. Drawdown as a function of time in borehole UE-25c $\# 2$ between the packers during the pumping test in borehole UE-25c \#3, October to December 1984, with residual drawdown from a preceding injection test subtracted.

32. Analytical solution for drawdown data from borehole UE-25c \#1 above the packers assuming an infinite, homogeneous, anisotropic, unconfined aquifer, pumping test in borehole UE-25c \#3, October to December 1984.

33. Analytical solution for recovery data from borehole UE-25c \#1 between the packers assuming an infinite, homogeneous, isotropic, confined aquifer, pumping test in borehole UE-25c \#3, October to December 1984.

34. Analytical solution for recovery data from borehole UE-25c $\# 2$ between the packers assuming an infinite, homogeneous, isotropic, confined aquifer, pumping test in borehole UE-25c \#3, October to December 1984.

35. Analytical solution for drawdown data from borehole UE-25c \#1 below the packers assuming an infinite, homogeneous, isotropic, confined aquifer with leakage from a confining unit without storage, pumping test in borehole UE-25c \#3, October to December 1984.

\section{TABLES}

1. Information collected at the $c$-hole complex for determination of rock hydrologic properties

2. Distances between pumped wells and monitored intervals in observation wells during some pumping tests conducted in 1984 in boreholes UE-25c \#2 and UE-25c \#3.

3. Stratigraphic column for the c-hole complex.

4. Transmissive intervals in borehole UE-25c \#1

5. Transmissive intervals in borehole UE-25c \#2

6. Transmissive intervals in borehole UE-25c \#3

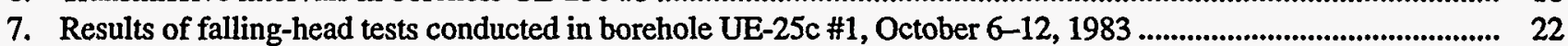

8. Results of pressure-injection tests conducted in borehole UE-25c \#1, October 6-12, 1983................................... 34

9. Summary of analyses of 1984 constant-flux aquifer tests in boreholes UE-25c \#1, UE-25c \#2, and UE-25c \#3.... 70

10. Summary of information from lithologic, television, acoustic televiewer, caliper, and temperature logs for borehole UE-25c \#1.

11. Summary of information from lithologic, television, acoustic televiewer, caliper, and temperature logs for borehole UE-25c \#2.

2. Summary of information from lithologic, television, acoustic televiewer, caliper, and temperature logs for borehole UE-25c \#3. 
Multiply inch-pound unit

cubic foot per day $\left(\mathrm{ft}^{3} / \mathrm{d}\right)$

foot

foot per day $(\mathrm{ft} / \mathrm{d})$

foot squared per day $\left(\mathrm{ft}^{2} / \mathrm{d}\right)$

gallon (gal)

gallon per minute (gal/min) inch (in.)

inch of mercury (in. of mercury)

mile

millidarcy $(\mathrm{mD})$

minute per square foot $\left(\mathrm{min} / \mathrm{ft}^{2}\right)$

pound per square inch (lb/in. ${ }^{2}$ )

reciprocal foot $\left(\mathrm{ft}^{-1}\right)$

square foot $\left(\mathrm{ft}^{2}\right)$
By

To obtain metric unit

cubic meter per day

meter

meter per day

meter squared per day

liter

liter per second

centimeter

meter of water

kilometer

square centimeter

minute per square meter

Kilopascal

reciprocal meter

square meter

Degree Fahrenheit $\left({ }^{\circ} \mathrm{F}\right)$ may be converted to degree Celsius $\left({ }^{\circ} \mathrm{C}\right)$ by using the following equation:

$$
{ }^{\circ} \mathrm{C}=5 / 9\left({ }^{\circ} \mathrm{F}-32\right) \text {. }
$$

Sea level: Altitudes in this report are referenced to the National Geodetic Vertical Datum of 1929 (NGVD of 1929), a geodetic datum derived from a general adjustment of the first-order level nets of the United States and Canada, formerly called the Sea Level Datum of 1929. 


\title{
Results and Interpretation of Preliminary Aquifer Tests in Boreholes UE-25c \#1, UE-25c \#2, and UE-25c \#3, Yucca Mountain, Nye County, Nevada
}

\author{
ByArthur L. Geldon
}

\section{Abstract}

Pumping and injection tests conducted in 1983 and 1984 in boreholes UE-25c \#1, UE-25c \#2, and UE-25c \#3 (the c-holes) at Yucca Mountain, Nevada, were analyzed with respect to information obtained from lithologic and borehole geophysical logs, core permeameter tests, and borehole flow surveys. The three closely spaced c-holes, each of which is about 3,000 feet deep, are completed mainly in nonwelded to densely welded, ash-flow tuff of the tuffs and lavas of Calico Hills and the Crater Flat Tuff of Miocene age. Below the water table, tectonic and cooling fractures pervade the tuffaceous rocks but are distributed mainly in 11 transmissive intervals, many of which also have matrix permeability. Although steep to vertical, south-striking (west dipping) fractures predominate in rocks penetrated by the c-holes, fractures in transmissive intervals generally are oriented diversely. From the water table, at depths between 1,312 and 1,320 feet, to a depth of 1,700 feet, transmissive intervals are unconfined; transmissive intervals between 1,800 and 2,700 feet respond to pumping as fissure-block or nonleaky, confined aquifers; below 2,700 feet, transmissive intervals are recharged by water released from faults that have offset and brecciated the rocks in these intervals. Miocene tuffaceous rocks and Paleozoic carbonate rocks at the c-hole complex appear to be connected hydraulically.

Heat-pulse flowmeter surveys indicate a change from generally small, downward to large, upward flow with depth, that is disrupted by pumping. Flow from unconfined to confined intervals occurs in response to hydraulic gradients established during pumping tests. Diverse aquifer tests consistently indicate layered heterogeneity and the dependence of calculated hydrologic properties on the volume of aquifer being tested. For the entire thickness of rocks penetrated by the test holes, cross-hole pumping and injection tests indicated transmissivity between 20,000 and 35,000 feet squared per day; storativity between 0.002 and 0.004 ; horizontal hydraulic conductivity between 30 and 40 feet per day; and vertical hydraulic conductivity between 2 and 5 feet per day.

\section{INTRODUCTION}

Information contained in this report is presented as part of ongoing investigations by the U.S. Geological Survey (USGS) regarding the hydrologic and geologic suitability of Yucca Mountain, Nevada, as a potential site for the storage of high-level nuclear waste in an underground mined geologic repository. This investigation was conducted in cooperation with the U.S. Department of Energy under Interagency Agreement DE-AI08-78ET44802, as part of the Yucca Mountain Site Characterization Project.

\section{Purpose and Scope}

This report presents previously unpublished syntheses of geologic and hydrologic data from boreholes UE-25c \#1, UE-25c \#2, and UE-25c \#3 (collectively called the c-holes) and descriptions, analyses, and interpretations of fluid-injection and withdrawal tests conducted in the c-holes. These tests were conducted between September 1983 and December 1984 to (1) help develop a conceptual model of the groundwater system at the c-hole complex; (2) provide a range in hydrologic properties for the rocks in tested intervals based on multiple analytical solutions applied to aquifer test data; and (3) provide information for designing hydraulic-stress tests and tracer tests within constraints imposed by initial test analyses. Analysis and interpretation of the preliminary aquifer tests at the c-holes were aided by published and unpublished data obtained between April 1985 and December 1992 that are listed 
in table 1. Interpretations presented in this report should be considered tentative and subject to change, as optimally designed hydraulic-stress and tracer tests are conducted and analyzed. This report updates some hydrogeologic information and corrects some erroneous information about aquifer tests in U.S. Geological Survey Water-Resources Investigations Report 92-4016 (Geldon, 1993).

\section{Acknowledgments}

The author is indebted to many people currently or formerly with the USGS and Fenix and Scisson, Inc., who assisted with data collection, processing, and analysis, including but not limited to: Richard K. Waddell, Jr., James R. Erickson, Devin L. Galloway, Michael P. Chornack, Charles T. Warren, David H. Lobmeyer, Robert W. Craig, John B. Czarnecki, Brent Anderson, Jack Kume, William J. Oatfield, Charles S. Washington, and Geoffrey Miller (USGS); Robin L. Reed, Byron W. Cork, Sandy Waddell, Eric P. Eshom, Jennifer B. Warner, Daniel O. Blout, Kirstin A. Johnson, Lynn D. Parrish, Heather Huckins, Thomas M. Howard, Eric Larsen, and Russell G. Lahoud (Fenix and Scisson, Inc.).

\section{PHYSICAL SETTING}

Boreholes UE-25c \#1, UE-25c \#2, and UE-25c \#3 are located in Nye County, Nevada, just east of the western boundary of the Nevada Test Site, approximately 90 miles northwest of Las Vegas. The c-holes are in the channel of an ephemeral stream that cuts through Bow Ridge parallel to and east of the main part of Yucca Mountain. The c-holes, other boreholes referred to in this report, and the potential high-level nuclear waste repository site are shown in figure 1. Yucca Mountain is situated in the arid Basin and Range physiographic province of the southwestern United States. Typical of the Basin and Range, the area around Yucca Mountain is characterized by narrow, predominantly northerly aligned mountain ranges separated by broad, alluvial basins (Frizzell and Shulters, 1990).

\section{Borehole Construction}

Boreholes UE-25c \#1, UE-25c \#2, and UE-25c \#3 are 100 to $251 \mathrm{ft}$ apart at the land surface (fig. 2). Lines connecting the boreholes delineate a triangle with an area of $11,050 \mathrm{ft}^{2}$. Because of borehole drift during drilling (fig. 2), interborehole distances at depth vary substantially from distances at the surface. For example, average horizontal distances between intervals monitored in some of the pumping tests conducted in the c-holes range from 92 to $280 \mathrm{ft}$ (table 2). Cumulative borehole drift in a vertical plane for each of the c-holes was less than a foot. As a result, measured depths to features within the c-holes did not require a true-depth correction for the purposes of this report.

Borehole UE-25c \#1 was completed in September 1983 (Fenix and Scisson, Inc., 1986). The top of the borehole is at an altitude of $3,709.28 \mathrm{ft}$ (Grady O'Brien, U.S. Geological Survey, written commun., 1993). As indicated by television (TV) and caliper logs listed in table 1, casing and concrete extend $1,371 \mathrm{ft}$ below the top of the borehole. The open part of the borehole was rotary-drilled with a 14.75-in.diameter bit through the bottom of the concrete to a depth of $1,511 \mathrm{ft}$ and a 9.875-in.-diameter bit from 1,511 to $2,990 \mathrm{ft}$. The borehole was cored with an 8.75-in.-diameter bit from 2,990 to 3,000 ft. Caliper logs indicate that the borehole walls are very irregular (plate 1). TV and caliper logs indicate that the bottom of the borehole has collapsed substantially since the borehole was completed. The bottom of the borehole was at a depth of 2,994 ft in September 1983,2,962 ft in November 1983, and 2,945 ft in December 1990.

Borehole UE-25c \#2 was completed in February 1984 (Fenix and Scisson, Inc., 1986). The top of the borehole is at an altitude of $3,715.25 \mathrm{ft}$ (Grady O'Brien, U.S. Geological Survey, written commun., 1993). As indicated by TV and caliper logs listed in table 1 , casing and concrete extend $1,365 \mathrm{ft}$ below the top of the borehole. The open part of the borehole was rotary-drilled with a 14.75-in.-diameter bit through the bottom of the concrete to a depth of 1,515 ft and a 9.875-in.-diameter bit from 1,515 to $3,000 \mathrm{ft}$. Caliper logs indicate that the borehole walls are very irregular (pl. 2). In figure 3, a close relationship is shown between the location of open, near vertical to vertical (dip $70^{\circ}-84^{\circ}$ ), southerly and northwesterly striking fractures and an enlarged, rugose section of borehole UE-25c \#2. TV and acoustic televiewer logs in the c-holes indicate that prominent fractures with other orientations, partings at contacts between geologic units, and drilling-induced sloughing, also, are associated with enlargement and rugosity in the c-holes. TV and caliper logs indicate that the bottom of borehole UE-25c \#2 has collapsed slightly since completion. The bottom of the borehole was at a depth of 2,999 ft in February 1984, 2,990 ft in August 1984, and 2,986 ft in June 1992.

Borehole UE-25c \#3 was completed in April 1984 (Fenix and Scisson, Inc., 1986). The top of the borehole is at an altitude of $3,715.25 \mathrm{ft}$ 
Table 1. Information collected at the c-hole complex for determination of rock hydrologic properties ${ }^{1}$

\begin{tabular}{|c|c|c|}
\hline Information & Source & Dates obtained \\
\hline & Borehole UE-25c \#1 & \\
\hline \multirow[t]{3}{*}{ Caliper logs } & Birdwell & 09/18/83 \\
\hline & Atlas Wireline Services & $12 / 11 / 90$ \\
\hline & USGS & $12 / 10 / 91$ \\
\hline Gyroscopic (borehole deviation) survey & Eastman & 09/18/83 \\
\hline Resistivity logs & Birdwell & 09/20/83 \\
\hline \multirow[t]{2}{*}{ Temperature logs (nonpumping) } & Birdwell & 09/20/83 \\
\hline & USGS & 12/09/91 \\
\hline Miscellaneous geophysical logs & Nelson and others (1991) & $08 / 21 / 83-11 / 20 / 83$ \\
\hline Tracejector survey (pumping) & Gearhart-Owen & $09 / 29 / 83$ \\
\hline Television logs & Westech & $09 / 17 / 83-11 / 18 / 83$ \\
\hline Acoustic televiewer log & Richard K. Waddell (USGS, written commun., 1984) & $10 / 31 / 83$ \\
\hline Lithologic log & Richard E. Spengler (USGS, written commun., 1984) & $2 / 84$ \\
\hline Core permeability analyses (9) & Holmes and Narver, Inc. & $03 / 14 / 84$ \\
\hline Pumping tests (2) & USGS, assisted by REECo & $09 / 27 / 83-10 / 02 / 83$ \\
\hline Falling-head (slug) tests (16) & USGS, assisted by TAM International & $10 / 06 / 83-10 / 12 / 83$ \\
\hline Pressure-injection tests (9) & USGS, assisted by TAM International & $10 / 08 / 83-10 / 12 / 83$ \\
\hline Heat-pulse flowmeter survey (nonpumping) & Frederick L. Paillet (USGS, written commun., 1992) & $12 / 12 / 91$ \\
\hline $\begin{array}{l}\text { Static water levels, atmospheric pressure, and } \\
\text { barometric efficiency }\end{array}$ & Galloway and Rojstaczer (1988) & $02 / 23 / 86-04 / 21 / 86$ \\
\hline \multirow[t]{2}{*}{ Borehole history } & Fenix and Scisson, Inc. (1986) & $08 / 10 / 83-02 / 01 / 85$ \\
\hline & Borehole UE-25c \#2 & \\
\hline \multirow[t]{4}{*}{ Caliper logs } & Birdwell & $02 / 28 / 84$ \\
\hline & Birdwell & $08 / 23 / 84$ \\
\hline & Atlas Wireline Services & $12 / 11 / 90$ \\
\hline & USGS & $12 / 14 / 91$ \\
\hline Gyroscopic (borehole deviation) survey & Sperry-Sun & $02 / 27 / 84$ \\
\hline Resistivity logs & Birdwell & $02 / 28 / 84$ \\
\hline \multirow[t]{2}{*}{ Temperature logs (nonpumping) } & Birdwell & $02 / 28 / 84$ \\
\hline & USGS & $12 / 14 / 91$ \\
\hline Miscellaneous geophysical logs & Nelson and others (1991) & $01 / 27 / 84-02 / 29 / 84$ \\
\hline Tracejector survey (pumping) & Gearhart-Owen & 03/12/84 \\
\hline \multirow[t]{2}{*}{ Television logs } & Westech & $02 / 08 / 84-04 / 13 / 84$ \\
\hline & Barbour Well Surveying Corporation & $06 / 02 / 92$ \\
\hline \multirow[t]{2}{*}{ Acoustic televiewer logs } & Richard K. Waddell (USGS, written commun., 1984) & $02 / 27 / 84$ \\
\hline & USGS & $12 / 14 / 91$ \\
\hline Lithologic log & Richard E. Spengler (USGS, written commun., 1984) & $03 / 84$ \\
\hline Core permeability analyses (3) & Alan L. Flint (USGS, written commun., 1993) & $12 / 92$ \\
\hline Pumping test & USGS, assisted by REECo & $03 / 07 / 84-03 / 18 / 84$ \\
\hline Constant-flux injection test & USGS, assisted by REECo & $10 / 30 / 84$ \\
\hline Heat-pulse flowmeter survey (nonpumping) & Frederick L. Paillet (USGS, written commun., 1992) & $12 / 16 / 91$ \\
\hline $\begin{array}{l}\text { Static water levels, atmospheric pressure and } \\
\text { barometric efficiency }\end{array}$ & Galloway and Rojstaczer (1988) & $02 / 23 / 86-04 / 21 / 86$ \\
\hline Borehole history & Fenix and Scisson, Inc. (1986) & $01 / 09 / 84-06 / 27 / 85$ \\
\hline
\end{tabular}


Table 1. Information collected at the c-hole complex for determination of rock hydrologic properties ${ }^{1}$--Continued

\begin{tabular}{|c|c|c|}
\hline Information & Source & Dates obtalned \\
\hline & Borehole UE-25c \#3 & \\
\hline \multirow{4}{*}{ Caliper logs } & Birdwell & $04 / 27 / 84$ \\
\hline & Birdwell & $03 / 21 / 85$ \\
\hline & Atlas Wireline Services & $12 / 11 / 90$ \\
\hline & USGS & $12 / 13 / 91$ \\
\hline Gyroscopic (borehole deviation) survey & Sperry-Sun & $04 / 26 / 84$ \\
\hline Resistivity logs & Birdwell & $04 / 30 / 84$ \\
\hline Temperature logs (nonpumping) & Birdwell & $04 / 30 / 84$ \\
\hline- & USGS & $12 / 31 / 91$ \\
\hline Miscellaneous geophysical logs & Nelson and others (1991) & $03 / 28 / 84-04 / 30 / 84$ \\
\hline Tracejector survey (pumping) & Gearhart-Owen & 05/07/84 \\
\hline \multirow[t]{2}{*}{ Television logs } & Westech & $04 / 13 / 84$ \\
\hline & Barbour Well Surveying Corporation & 06/02/92 \\
\hline \multirow[t]{2}{*}{ Acoustic televiewer logs } & Richard K. Waddell (USGS, written commun., 1984) & $04 / 27 / 84$ \\
\hline & USGS & $12 / 13 / 91$ \\
\hline Lithologic log & Richard E. Spengler (USGS, written commun., 1984) & $05 / 84$ \\
\hline Core permeability analyses ( 8 ) & Alan L. Flint (USGS, written commun., 1993) & $12 / 92$ \\
\hline \multicolumn{3}{|l|}{ Pumping tests } \\
\hline First test & USGS, assisted by REECo & $05 / 14 / 84-06 / 12 / 84$ \\
\hline Second test & USGS, assisted by REECo & $10 / 30 / 84-12 / 09 / 84$ \\
\hline Heat-pulse flowmeter survey (nonpumping) & Frederick L. Paillet (USGS, written commun., 1992) & $12 / 15 / 91$ \\
\hline $\begin{array}{l}\text { Static water levels, atmospheric pressure and } \\
\text { barometric efficiency }\end{array}$ & Galloway and Rojstaczer (1988) & $02 / 23 / 86-04 / 21 / 86$ \\
\hline Borehole history & Fenix and Scisson, Inc. (1986) & $03 / 20 / 84-06 / 27 / 85$ \\
\hline \multicolumn{3}{|c|}{ Boreholes near the c-holes } \\
\hline \multicolumn{3}{|l|}{ Core permeability analyses } \\
\hline UE-25b \#1 (12) & Lobmeyer and others (1983) & unknown \\
\hline USW H-1 (15) & Rush and others (1983) & unknown \\
\hline USW G-3 (22) & Philip Nelson (USGS, written commun., 1992) & unknown \\
\hline USW G-4 (20) & Philip Nelson (USGS, written commun., 1992) & unknown \\
\hline
\end{tabular}

${ }^{1}$ Any use of trade names in this report is for descriptive purposes only and does not imply endorsement by the U.S. Geological Survey.

4 Results and Interpretation of Preliminary Aquifer Tests in Boreholes UE-25c \#1, UE-25c \#2, and UE-25c \#3, Yucca Mountain, Nye County, Nevada 


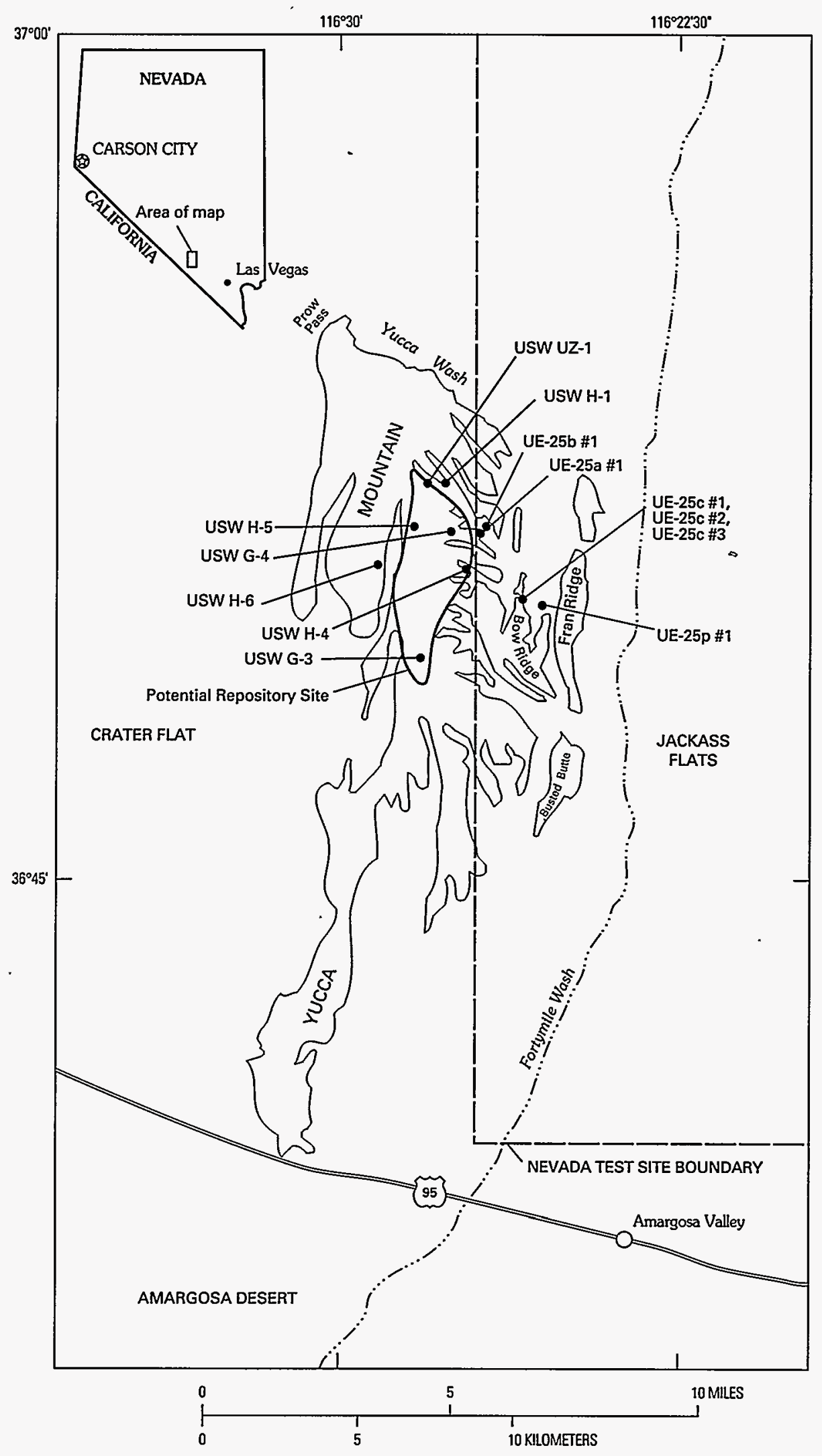

Figure 1. Location of Yucca Mountain, boreholes UE-25c \#1, UE-25c \#2, and UE-25c \#3, and nearby boreholes used for hydrologic investigations. 


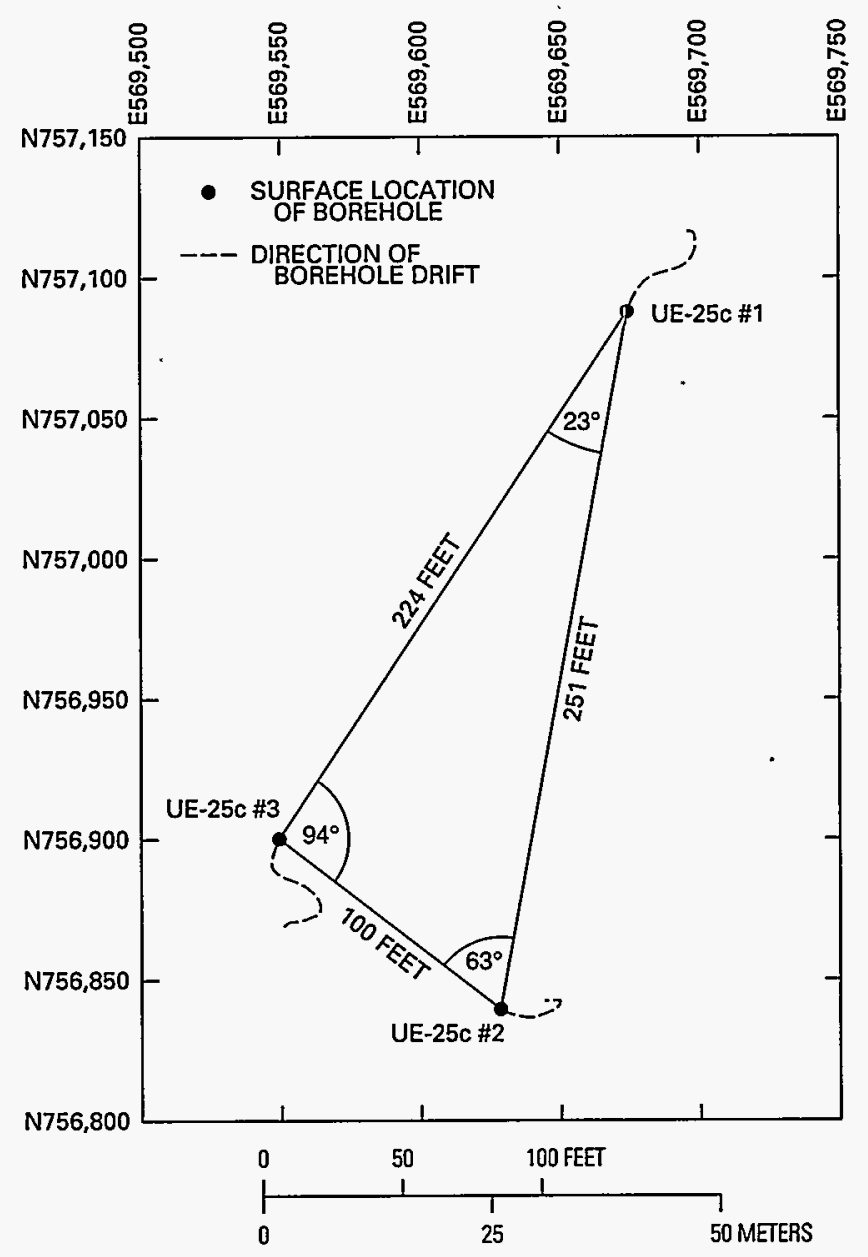

Figure 2: Surface location and drift of boreholes UE-25c \#1, UE-25c \#2, and UE-25c \#3.

Table 2. Distances between pumped wells and monitored intervals in observation wells during some pumping tests conducted in 1984 in boreholes UE-25c \#2 and UE-25c \#3

\begin{tabular}{|c|c|c|}
\hline Connected points & $\begin{array}{l}\text { Monitored Interval } \\
\text { (feet below land } \\
\text { surface) }\end{array}$ & $\begin{array}{c}\text { Thickness- } \\
\text { welghted } \\
\text { average } \\
\text { distance } \\
\text { (feet) }\end{array}$ \\
\hline \multicolumn{3}{|c|}{ Borehole UE-25c \#2 test, March 1984} \\
\hline UE-25c \#1 above packers to UE-25c \#2 & $1,371-2,510$ & 270 \\
\hline UE-25c \#1 between packers to UE-25c \#2 & $2,520-2,600$ & 277 \\
\hline \multicolumn{3}{|c|}{ Borehole UE-25c \#3 test, May-June 1984} \\
\hline UE-25c \#1 above packers to UE-25c \#3 & $1,371-1,595$ & 256 \\
\hline UE-25c \#1 between packers to UE-25c \#3 & $1,605-1,680$ & 259 \\
\hline \multicolumn{3}{|c|}{ Borehole UE-25c \#3 test, October-December 1984} \\
\hline UE-25c \#1 above packers to UE-25c \#3 & $1,371-2,514$ & 267 \\
\hline UE-25c \#1 between packers to UE-25c \#3 & $2,524-2,594$ & 280 \\
\hline UE-25c \#1 below packers to UE-25c \#3 & $2,603-3,000$ & 280 \\
\hline UE-25c \#2 between packers to UE-25c \#3 & $2,364-2,475$ & 92 \\
\hline
\end{tabular}

6 Results and Interpretation of Preliminary Aquifer Tests in Boreholes UE-25c \#1, UE-25c \#2, and UE-25c \#3, Yucca Mountain, Nye County, Nevada 


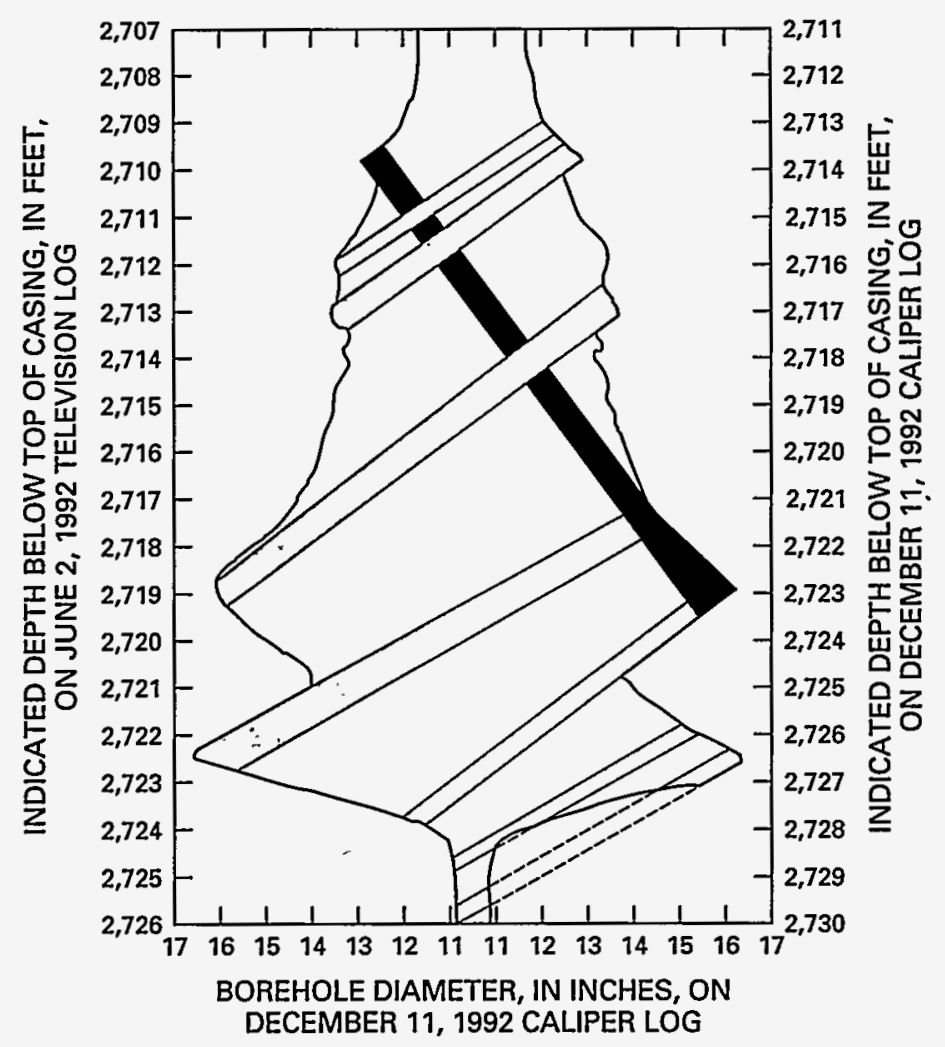

\section{EXPLANATION}

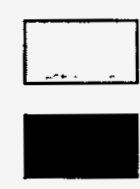

OPEN, NEAR VERTICAL, SOUTH-STRIKING $\left(160^{\circ}-195^{\circ}\right)$ FRACTURE-Dashed where extrapolated outside borehole

OPEN, VERTICAL, NORTHWEST-STRIKING $\left(330^{\circ}\right)$ FRACTURE

Figure 3. Relation between fractures and borehole diameter in an enlarged, rugose interval of borehole UE-25c \#2.

(Grady O'Brien, U.S. Geological Survey, written commun., 1993). As indicated by TV and caliper logs listed in table 1 , casing and concrete extend $1,368 \mathrm{ft}$ below the top of the borehole. The open part of the borehole was rotary-drilled with a 14.75-in.-diameter bit through the bottom of the concrete to a depth of 1,514 ft and a 9.875-in.-diameter bit from 1,514 to $3,000 \mathrm{ft}$. Caliper logs indicate that the borehole walls are very irregular (pl. 3). TV and caliper logs indicate that the bottom of the borehole has collapsed substantially since completion. The bottom of the borehole was at a depth of 3,000 ft in April 1984, 2,976 ft in March 1985, and 2,954 ft in June 1992.

\section{Site Geology}

The c-holes are completed in Miocene tuffaceous rocks that are covered by a thin veneer $(0-80 \mathrm{ft})$ of Quaternary alluvium and underlain by dolomite of the Silurian Roberts Mountain Formation and Lone Mountain Dolomite (Carr and others, 1986; Geldon, 1993). Based on information obtained from borehole UE-25p \#1, 2,028 ft southeast of borehole UE-25c \#1, the Miocene rocks are estimated to be about $5,000 \mathrm{ft}$ thick in the vicinity of the c-holes.

Northerly trending, high-angle faults, such as the Paintbrush Canyon and Bow Ridge Faults, have offset and tilted the Miocene rocks in the vicinity of the 
c-holes (Scott and Bonk, 1984). The dip of the Miocene rocks increases in fault blocks from $5^{\circ}$ to $10^{\circ}$ on the crest of Yucca Mountain to $15^{\circ}$ to $20^{\circ}$ at the c-hole complex (Frizzell and Shulters, 1990; Geldon, 1993). According to Scott (1990), the highangle faults merge listrically at depth with a detachment fault that forms the contact between Miocene and Paleozoic rocks in the Yucca Mountain area. However, Carr (1990) considers the contact between the Miocene and Paleozoic rocks to be an unconformity, and the high-angle faults in the Yucca Mountain area to be collapse faults bordering a caldera centered in Crater Flat (location shown in fig. 1).

As indicated in table 3, Miocene rocks penetrated by the c-holes include the Tiva Canyon and Topopah Spring Members of the Paintbrush Tuff, the tuffs and lavas of Calico Hills, and the Prow Pass, Bullfrog, and Tram Members of the Crater Flat Tuff. These geologic units predominantly consist of ash-flow tuff, that is devitrified to vitrophyric and nonwelded to densely welded. Bedded tuff, consisting of ash-fall tuff and volcaniclastic rocks (reworked tuff), is interlayed with the ash-flow tuff at the base of formations and members. Unique to boreholes in the Yucca Mountain area, a tuff breccia occurs in the Tram Member in an interval where moderately welded ash-flow tuff is present in nearby boreholes (Geldon, 1993). Faults that intersect at the c-hole complex apparently have brecciated the upper nonwelded to partially welded part of the Tram Member and cut out the moderately welded part (Geldon, 1993). All of the geologic units at the c-hole complex have been altered partially to zeolite and clay minerals below the water table, which according to information from Robison and other (1988) and USGS files, occurs at depths of between 1,312 and $1,320 \mathrm{ft}$ below the land surface (at altitudes of 2,394 to 2,396 ft above the NGVD of 1929). The water table is slightly above or below the contact between the Paintbrush Tuff and the tuffs and lavas of

Table 3. Stratigraphic column for the c-hole complex

[Summarized from lithologic logs prepared by Richard E. Spengler, USGS, written commun., 1984; dashed line in depth column indicates an unconformity]

\begin{tabular}{|c|c|c|c|c|}
\hline \multirow{2}{*}{ Geologic unit } & \multirow{2}{*}{ Generalized description } & \multicolumn{3}{|c|}{$\begin{array}{l}\text { Depth below land surface } \\
\text { (feet) }\end{array}$} \\
\hline & & UE-25c \#1 & UE-25c \#2 & UE-25C \#3 \\
\hline Alluvium & Sand and gravel & Absent & $0-70$ & $0-80$ \\
\hline \multicolumn{5}{|l|}{ Paintbrush Tuff } \\
\hline Tiva Canyon Member & $\begin{array}{l}\text { Moderately to densely welded ash-flow tuff with thin } \\
\text { basal bedded tuff }\end{array}$ & $0-315$ & $70-290$ & $80-290$ \\
\hline $\begin{array}{l}\text { Topopah Spring } \\
\text { Member }\end{array}$ & $\begin{array}{l}\text { Moderately to densely welded ash-flow tuff with inter- } \\
\text { vals containing lithophysae; thin vitrophyre and non- } \\
\text { welded tuff layers at the top and bottom }\end{array}$ & $315-1,332$ & $290-1,316$ & $290-1,300$ \\
\hline Tuffs and lavas of & Nonwelded ash-flow tuff & $1,332-1,593$ & $1,316-1,570$ & $1,300-1,560$ \\
\hline Calico Hills & Bedded tuff & $-1,593-1,691$ & $1,570-1,672$ & $1,560-1,629$ \\
\hline \multicolumn{5}{|l|}{ Crater Flat Tuff } \\
\hline \multirow[t]{4}{*}{ Prow Pass Member } & Nonwelded to partially welded ash-flow tuff & $1,692-1,838$ & $1,673-1,810$ & $1,630-1,780$ \\
\hline & Moderately welded ash-flow tuff & $1,838-1,860$ & $1,810-1,840$ & $1,780-1,830$ \\
\hline & Partially welded to nonwelded ash-flow tuff & $-\overline{1,860-2, \overline{118}}$ & $1,840-2,110$ & $1,830-2,085$ \\
\hline & Bedded tuff & $2,118-2,152$ & $2,110-2,138$ & $2,085-2,112$ \\
\hline \multirow[t]{4}{*}{ Bullfrog Member } & Nonwelded to partially welded ash-flow tuff & $\overline{2,15 \overline{3}}-2, \overline{2} 6 \overline{0}$ & $2, \overline{139} \overline{-2}, \overline{240}-$ & $2,112-2,210$ \\
\hline & Moderately to densely welded ash-flow tuff & $2,260-2,480$ & $2,240-2,460$ & $2,210-2,430$ \\
\hline & Partially welded to nonwelded ash-flow tuff & $2,480-2,695$ & $2,460-2,675$ & $2,430-2,650$ \\
\hline & Bedded tuff & $2,695-2,716$ & $2,675-2,719$ & $2,650-2,670$ \\
\hline \multirow[t]{3}{*}{ Tram Member } & Nonwelded to partially welded ash-flow tuff & $2,716-2,775$ & $2,719-2,775$ & $2,670-2,804$ \\
\hline & Indurated tuff breccia & $2,775-2,975$ & $2,775-2,935$ & $2,804-3,000$ \\
\hline & Partially welded, lithic ash-flow toff & $2,975-3,000$ & $2,935-3,000$ & Not reached \\
\hline
\end{tabular}

8 Results and Interpretation of Preliminary Aquifer Tests in Boreholes UE-25c \#1, UE-25c \#2, and UE-25c \#3, Yucca Mountain, Nye County, Nevada 
Calico Hills in individual boreholes (see tables in the Supplementary Data section at the end of this report).

The tuffaceous rocks at the c-hole complex are pervaded by tectonic and cooling fractures. Fracture orientations and frequency in the geologic units penetrated by the $c$-holes vary from unit to unit and among boreholes, but for the tuffs and lavas of Calico Hills and the Crater Flat Tuff, in general, fractures strike predominantly south-southeast to south-southwest (fig. 4) and dip $50^{\circ}$ to $87^{\circ}$ to the west-southwest or west-northwest. Largely because of the Tram Member of the Crater Flat Tuff, the second most abundant fractures in the c-holes strike north-northwest to north-northeast and dip east-northeast to east-southeast. Many of the latter fractures are shallow-dipping or mineralized. The least common fractures generally strike to the east (between $70^{\circ}$ and $110^{\circ}$ ) and west (between $250^{\circ}$ and $290^{\circ}$ ), and many of these are shallow-dipping or mineralized. In contrast to boreholes UE-25c \#1 and UE-25c \#2, southwesterly, westerly, and northwesterly-striking fractures are more common in borehole UE-25c \#3 than southeasterly, easterly, and northeasterly striking fractures. Borehole UE-25c \#3 differs from the other two c-holes, also, in having a smaller proportion of steep to vertical, nonmineralized fractures to mineralized or shallow, nonmineralized fractures. Because of fault brecciation, fracture frequency is greatest in the Tram Member. The bedded zone of the tuffs and lavas of Calico Hills is also very fractured. On the average, moderately to densely welded zones of the Prow Pass and Bullfrog Members are more fractured than bedded zones, which in turn, are more fractured than nonwelded to partially welded zones (pls. 1-3).

\section{SITE HYDROLOGY}

The tuffaceous rocks penetrated by the c-holes are not uniformly permeable. Variations in fracture frequency and openness and matrix permeability confine ground-water movement to relatively thin intervals in the tuffs and lavas of Calico Hills and the Crater Flat Tuff. In combination, laboratory analyses of core permeability, fracture (television and acoustic televiewer) logs, caliper logs, resistivity logs, temperature logs, tracejecter surveys during pumping tests, and heatpulse flowmeter surveys identify the transmissive intervals.

\section{Matrix Permeability}

Permeameter tests were done on 20 samples of core from boreholes UE-25c \#1, UE-25c \#2, and UE-25c \#3 (table 1) to determine horizontal and vertical matrix permeability. These samples were insufficient to characterize the variation in matrix permeability with depth throughout the entire thickness of tuffaceous rocks penetrated by the c-holes. However, with the addition of permeability analyses for 69 samples of core from four boreholes within a threemile radius of the $c$-hole complex (table 1), profiles of horizontal matrix permeability as a function of depth within geologic units (sample depth divided by the thickness of the geologic unit from which the sample was obtained) were prepared for the $c$-holes and nearby boreholes (fig. 5).

To construct the permeability profile shown in figure 5 , it was assumed that permeability values would be the same at the same normalized depths within geologic units at different locations. However, it was recognized that this assumption might be incorrect locally because of lateral changes in lithology. Some points shown in figure 5 that deviate substantially from the plotted permeability profile were ignored under the assumption that they represent either locally unusual lithology or a poorly correlated permeability value.

Horizontal matrix permeability as a function of depth for each of the c-holes was calculated from the permeability and percent of thickness values in figure 5 and depths of stratigraphic horizons listed in table 3. As indicated on plates 1-3, horizontal matrix permeability in the tuffaceous rocks at the c-hole complex is estimated to range from 0.001 to $20 \mathrm{mD}$. With respect to matrix permeability, the tuffaceous rocks at the c-hole complex are slightly anisotropic (fig. 6). Matrix permeability is slightly larger in the horizontal direction than in the vertical direction. Expressed as a function of horizontal matrix permeability $\left(k_{r}\right)$, vertical matrix permeability $\left(k_{z}\right)$ can be found from the following empirically derived equation $\left(R^{2}=0.71\right)$ :

$$
\log k_{z}=0.88 \log k_{r}-0.36
$$

Vertical matrix permeability in the tuffaceous rocks at the $c$-hole complex is estimated to range from 0.001 to $6 \mathrm{mD}$. 

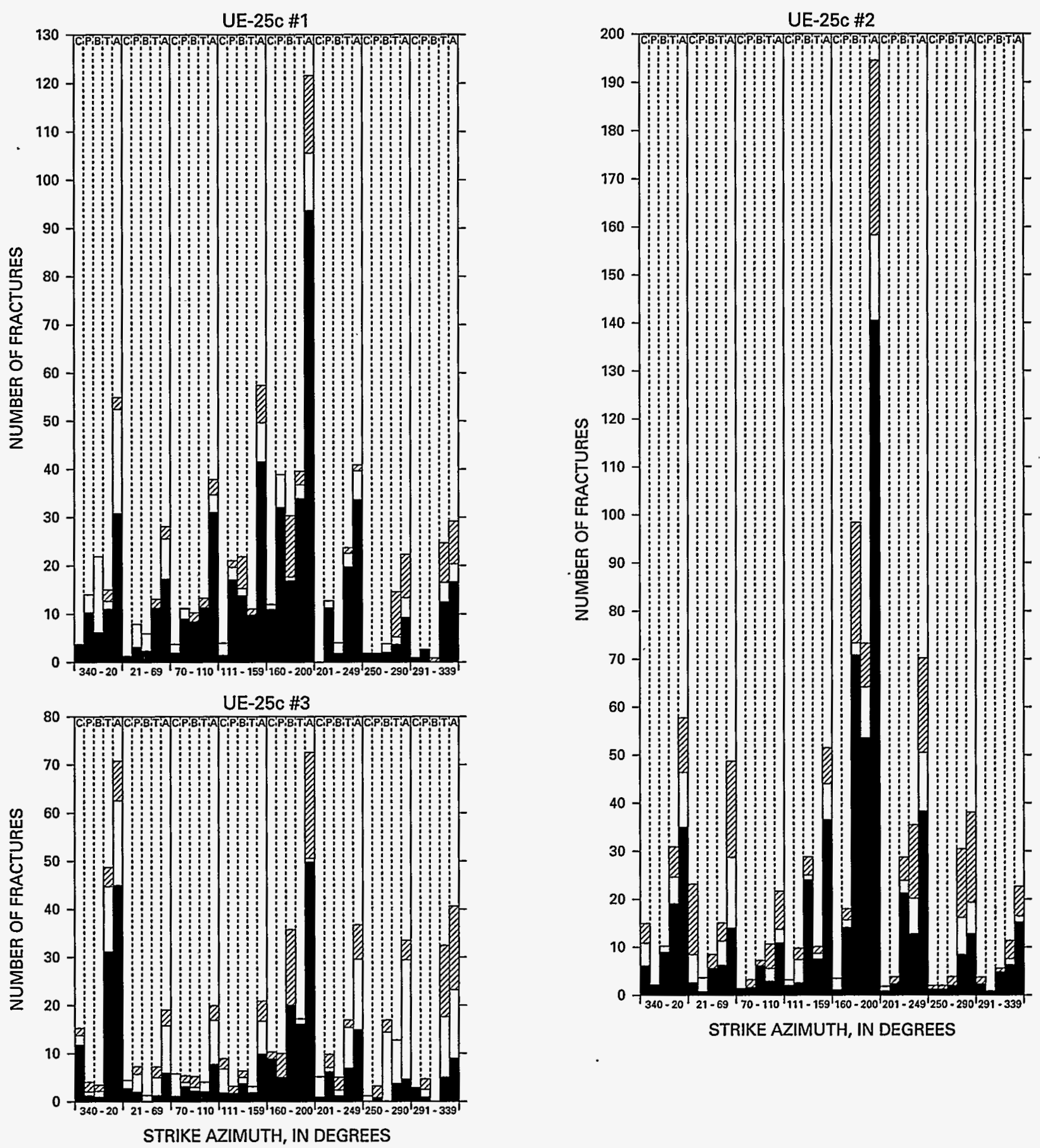

EXPLANATION

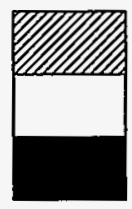

PARTLY OR ENTIRELY MINERALIZED

NONMINERALIZED, SHALLOW (<50 DEGREE DIP)

NONMINERALIZED, STEEP TO VERTICAL

c TUFFS AND LAVAS OF CALICO HILLS

P PROW PASS MEMBER OF THE CRATER FLAT TUFF

B BULLFROG MEMBER OF THE CRATER FLAT TUFF

T TRAM MEMBER OF THE CRATER FLAT TUFF

A ALL GEOLOGIC UNITS

Figure 4. Frequency distribution of fracture orientations in boreholes UE-25c \#1, UE-25c \#2, and UE-25c \#3. (Based on TV and acoustic televiewer logs. Fractures identified in the c-holes are listed in the Supplementary Data section at the end of this report.)

10 Results and Interpretation of Preliminary Aquifer Tests in Boreholes UE-25c \#1, UE-25c \#2, and UE-25c \#3, Yucca Mountain, Nye County, Nevada 


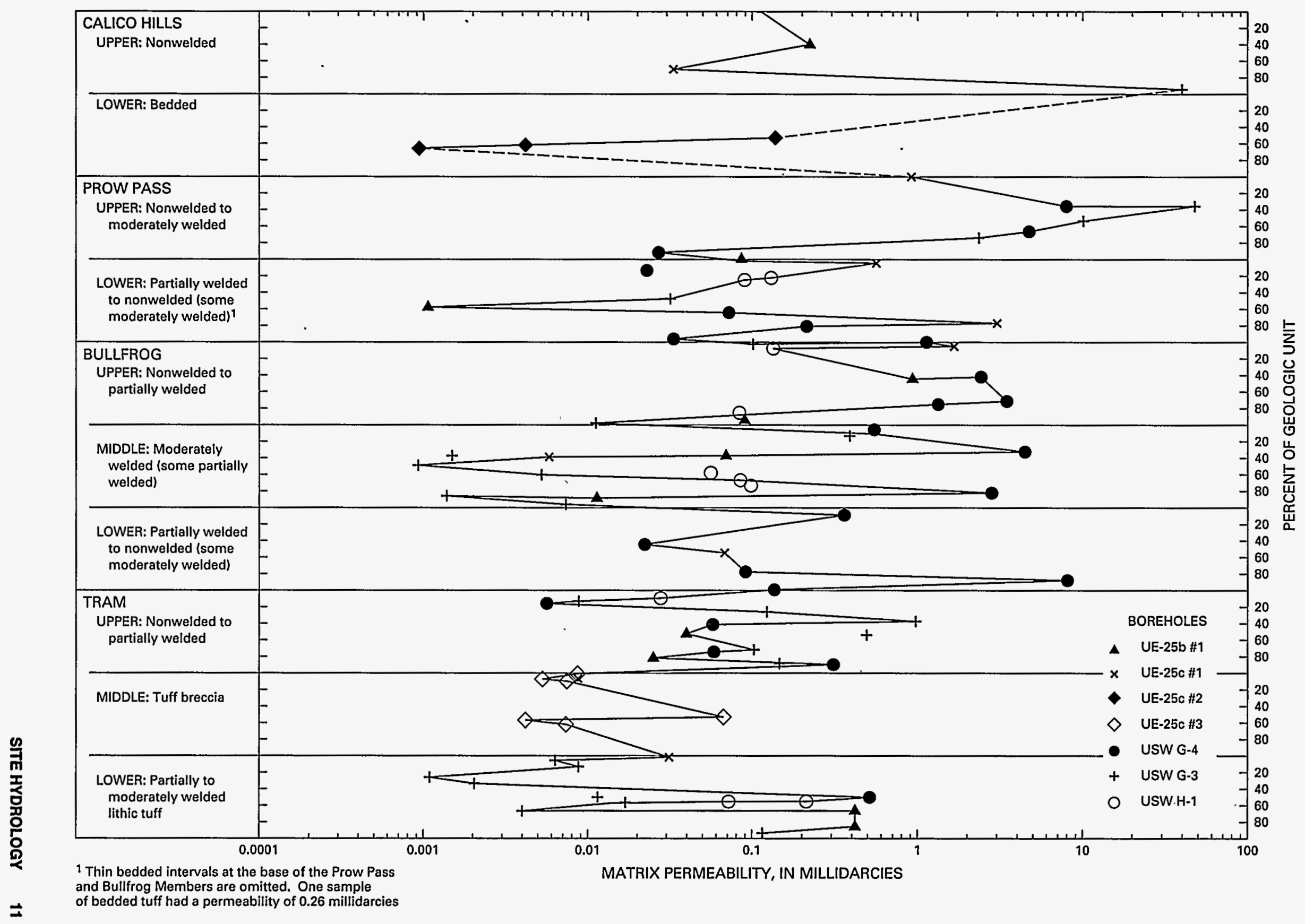

Figure 5. Horizontal matrix permeability in the tuffs and lavas of Calico Hills and Crater Flat Tuff, east-central Yucca Mountain area, as a function of depth within geologic units (based on core analyses listed in table 1). 


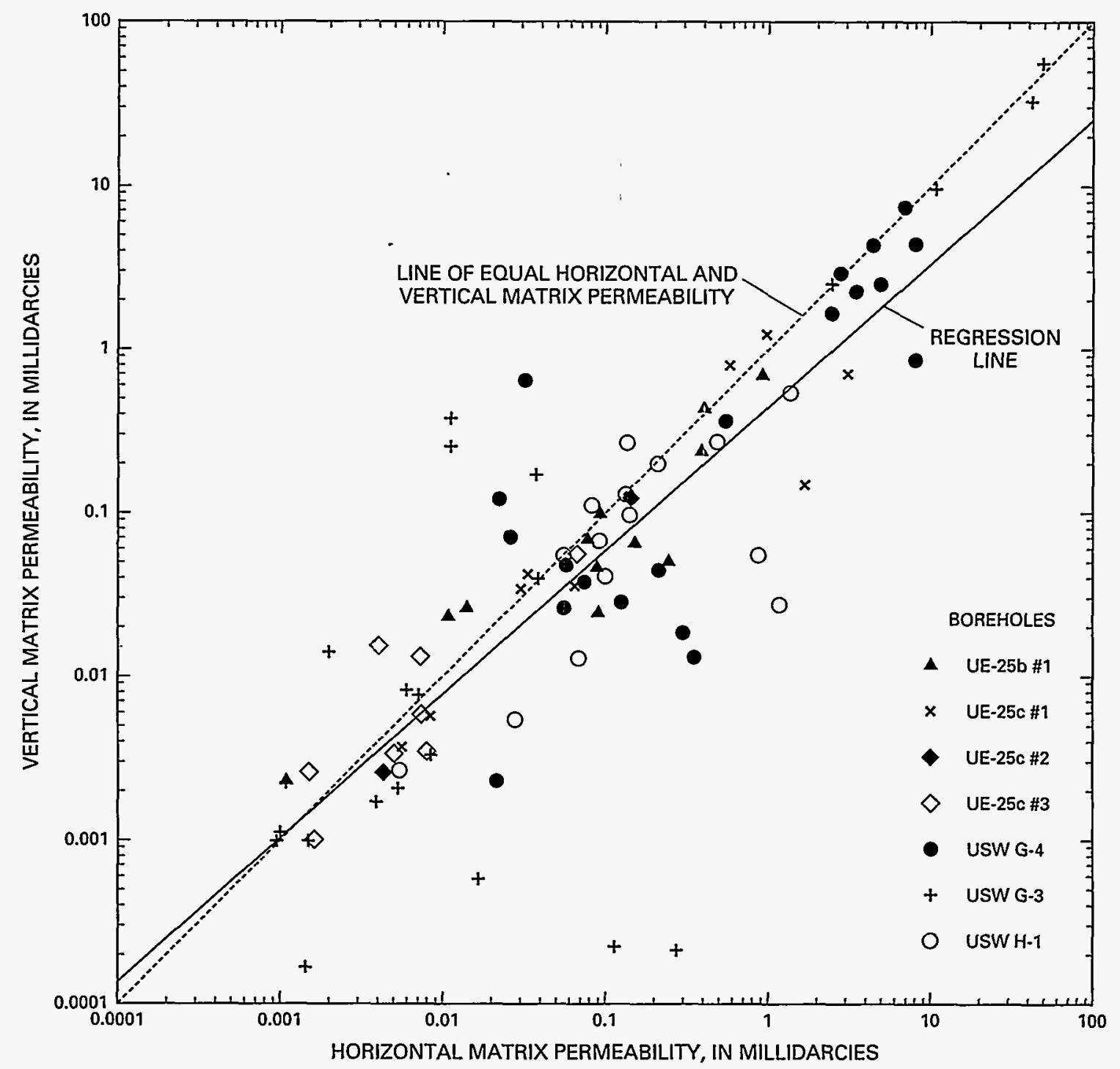

Figure 6. Relation of vertical to horizontal matrix permeability in core samples from the tuffs and lavas of Calico Hills and Crater Flat Tuff in the c-holes and nearby boreholes.

\section{Heat-Pulse Flowmeter Surveys}

Heat-pulse flowmeter surveys were conducted in each of the c-holes in December 1991 by Alfred E. Hess and Frederick L. Paillet of the USGS Borehole Geophysics Research Project to identify zones of intraborehole flow under natural hydraulic gradients (undisturbed by pumping or drilling). As described by Hess (1990), the method used involves lowering the flowmeter probe by cable to intervals of a borehole previously identified by fracture (television and acoustic televiewer) logs, caliper logs, and temperature logs as possibly transmissive intervals. Measurements are made with the probe above and below an interval of interest. A packer is inflated above the probe to restrict the measurement to the depth of interest. The flow measurement is made by releasing a heat pulse from an open grid of resistance wire and timing the movement of the heat pulse to sensors located at equal distances above and below the heat source. A positive deflection on a strip-chart recording of heatpulse transit time indicates movement of the heat pulse to the upper sensor and, hence, upward intraborehole flow. A negative deflection on a strip-chart recorder indicates movement of the heat pulse to the lower sensor and, hence, downward intraborehole flow. Heatpulse transit time is converted to flow rate by an empirically derived calibration equation for the probe.

12 Results and Interpretation of Preliminary Aquifer Tests in Boreholes UE-25c \#1, UE-25c \#2, and UE-25c \#3, Yucca Mountaln, Nye County, Nevada 
Heat-pulse flowmeter surveys indicated distinctly different patterns of intraborehole flow in each of the c-holes (pls. 1-3). In borehole UE-25c \#1, the flow fluctuated slightly but remained less than $0.09 \mathrm{gal} / \mathrm{min}$ and downward from 1,505 to about $2,520 \mathrm{ft}$. Below about 2,520 ft, the intraborehole flow became upward. The upward flow increased from 0 to $1.18 \mathrm{gal} / \mathrm{min}$ between about 2,520 and $2,735 \mathrm{ft}$, decreased to $0.91 \mathrm{gal} / \mathrm{min}$ between 2,735 and $2,765 \mathrm{ft}$, and became too small to measure reliably between 2,765 and $2,830 \mathrm{ft}$.

Similar to the pattern in borehole UE-25c \#1, flow in borehole UE-25c \#2 was downward in the top of the borehole and upward in the bottom of the borehole. However, downward and upward flow in borehole UE-25c \#2 remained small (less than $0.15 \mathrm{gal} / \mathrm{min}$ ) throughout the entire surveyed part of the borehole, and the change from downward to upward flow was $230 \mathrm{ft}$ lower than in borehole UE-25c \#1.

In contrast to the situation in boreholes UE-25c \#1 and UE-25c \#2, the flow in borehole UE-25c \#3 was upward throughout the entire surveyed part of the borehole, although it is possible that small downward flow might be occurring above the uppermost measuring depth. The flow in borehole UE-25c \#3 decreased from 0.10 to $0.05 \mathrm{gal} / \mathrm{min}$ between 1,505 and $1,650 \mathrm{ft}$, increased gradually to $0.08 \mathrm{gal} / \mathrm{min}$ between 1,650 and $2,275 \mathrm{ft}$, increased sharply to $4.0 \mathrm{gal} / \mathrm{min}$ between 2,275 and $2,550 \mathrm{ft}$, and decreased from 4.0 to $1.7 \mathrm{gal} / \mathrm{min}$ between $2,800 \mathrm{ft}$ and the bottom of the borehole.

As described in the next section, changes in flow in the c-holes generally coincide with zones of moderately to very fractured rock. Faults, partings, and intervals with relatively large matrix permeability, also influence intraborehole flow.

\section{Transmissive Intervals}

The best indicators of transmissivity are aquifer tests and numerical modeling. However, both techniques require some knowledge of hydrogeologic conditions in advance of use for the most reliable calculation of hydrologic properties. Diverse laboratory and geophysical data obtained at the c-hole complex from 1983-1992 were used to determine transmissive intervals in and between the c-holes in order to improve the analysis and interpretation of preliminary aquifer tests conducted at the c-hole complex. For example, knowing that ground-water flow was occurring in only $50 \mathrm{ft}$ of a packed-off interval $500-\mathrm{ft}$ thick instead of the entire interval, substantially would change the calculation of hydraulic conductivity from a transmissivity value determined by a pumping test. The analytical solution used to calculate transmissivity from drawdown, residual drawdown, or recovery data, and hence the numerical value obtained, would be expected to differ substantially if pre-test analysis showed that the source of ground water in a borehole was a fracture zone, an unfractured interval with large matrix permeability, a fault, or gravity drainage from the water table. In this study, the following criteria were used to identify transmissive intervals:

1. Gains and losses in intraborehole flow detected during heat-pulse flowmeter surveys;

2. Gains in discharge detected by tracejector surveys during pumping tests;

3. Inflections in nonpumping temperature gradients (caused by inflow, outflow, upflow, or downflow);

4. Relatively low resistivity associated with moderate to intense fracturing, relatively large matrix permeability, or partings (indicating that the resistivity is related to water and not weathering, mineralization, or other factors); and

5. Borehole enlargement associated with fracture zones, an indicator of the openness of individual fractures, or the presence of cavities created by fracture intersections.

Transmissive intervals in each of the c-holes and their characteristics are listed in tables 4-6. Figure 7, a hydrogeologic section of the c-holes, drawn along lines shown in figure 2, extrapolates transmissive intervals between the c-holes. For purposes of discussion in this report, the c-hole transmissive intervals informally were grouped into four aquifers that are separated by three confining units. The aquifers cannot be considered as formal hydrogeologic units because (1) the aquifers are defined largely by the extent of fracturing within them; (2) fractures are spatially related to faults at the c-hole complex; and (3) in different areas, faults and related fractures can be expected to penetrate geologic units differently than at the c-hole complex.

\section{Calico Hills Aquifer}

The Calico Hills aquifer extends from the water table, at depths between 1,312 and $1,320 \mathrm{ft}$ to about $1,700 \mathrm{ft}$ below land surface and is unconfined. It consists of three relatively thin zones of moderately to very fractured rock separated by unfractured to sparsely fractured rock, much of which contains large matrix permeability (fig. 7). Fractures, some of which are 
Table 4. Transmissive intervals in borehole UE-25c \#1

[Features discussed briefly in this table are shown in detail on plate 1]

\section{Depth}

below land

surface

$$
\text { (foot) }
$$

1,406-1,516 Poor visibility but believed to be sparsely to moderately fractured. Known fractures shallow-near vertical, north, south, southeast, and west-striking

1,521-1,593 Very fractured to 1,544 ft, large matrix permeability below; fractures are steep-vertical, north, east, southeast, south, and west-striking

1,623-1,639 Very fractured; fractures are near vertical-vertical, south-striking

1,691-1,692 Open parting at Calico Hills-Crater Flat contact

1,803-1,846 Very fractured, large matrix permeability; fractures are steep-vertical, mostly north, south, southeast, and southwest-striking

1,860-1,861 Open parting between moderately welded and partially welded to nonwelded zones of Prow Pass Member

1,919-1,925 Very fractured; fractures are open, shallow-steep, north, east, and south-striking

1,963-1,975 Moderately fractured; fractures are open, shallow, north-striking

2,050-2,156 Poor visibility but believed to be sparsely to very fractured; known fractures are shallow-vertical, mostly south and northeast-striking. Intervals with large matrix permeability and an open parting at the Prow Pass-Bullfrog contact

2,215-2,260 Very fractured to $2,243 \mathrm{ft}$, large matrix permeability below; fractures, some of which are open, are shallow-vertical, north, southeast, and south-striking

2,392-2,457 Sparsely to very fractured, with large matrix permeability below $2,415 \mathrm{ft}$; fractures are near vertical-vertical, south and east-striking

2,463-2,560 Very fractured rock separated by thin intervals of unfractured rock; fractures, many of which are open are steep-vertical, south, east, and southeast-striking

2,560-2,604 Moderately to very fractured; fractures are open, shallow-steep, north and northeast-striking and near vertical or vertical, east-striking

2,656-2,715 Moderately fractured, large matrix permeability; fractures are shallow-steep, northstriking

2,729-2,752 Very fractured; fractures, some of which are open, are shallow-vertical and diversely oriented

2,759-2,790 Very fractured; fractures, some of which are open, are shallow-steep, mostly south and southwest-striking. Two of the fractures comprise the Paintbrush Canyon Fault zone

2,790-2,840 Very fractured; fractures, some of which are open, are steep-vertical and diversely oriented

2,890-2,915 Very fractured; fractures are near vertical-vertical, diversely oriented

2,921-2,941 Very fractured; fractures are shallow-vertical, diversely oriented

2,960-2,980 Moderately fractured(?): uncertain because interval concealed by borehole collapse

\begin{tabular}{|c|c|c|}
\hline $\begin{array}{l}\text { Intraborehole flow } \\
\text { (gallons per minute) }\end{array}$ & $\begin{array}{l}\text { Pumping } \\
\text { dis- } \\
\text { charge } \\
\text { (percent) }\end{array}$ & Supporting Information \\
\hline 20.09 down & 0 & Low resistivity \\
\hline 0.02 out & 0 & $\begin{array}{l}\text { Low resistivity, concave temperature } \\
\text { gradient inflection }\end{array}$ \\
\hline 0.01 out & 0 & Low resistivity \\
\hline 0.02 in and down & $\mathbf{0}$ & $\begin{array}{l}\text { Low resistivity, convex temperature } \\
\text { gradient inflection }\end{array}$ \\
\hline \multirow[t]{2}{*}{0.02 out } & 0 & Borehole enlargement \\
\hline & 0 & Abrupt resistivity decrease \\
\hline 0.02 in and down & 0 & Low resistivity, borehole enlargement \\
\hline 0.01 out & 0 & Very low resistivity \\
\hline
\end{tabular}

0.01 in and down

0.01 out

0.03 in and down

0.12 out (changing

from down to up at

$2,520 \mathrm{ft}$ )

0.76 out

0.38 out

0.29 in to maximum upward flow of 1.18

$<0.91$ in and up

Small up

Small up(?)

Small up(?)

Small up(?)
Low resistivity, borehole enlargement

0

Low resistivity, borehole enlargement

0

0 Low resistivity, borehole enlargement, pronounced concave temperature gradient inflection

64 Very low resistivity, convex temperature gradient inflection, borehole enlargement

0 Low resistivity, borehole enlargement

0 Very low resistivity, concave temperature gradient inflection, borehole enlargement

5 Convex temperature gradient inflection, extensive borehole enlargement

0 Borehole enlargement

11 Concave temperature gradient inflection, borehole enlargement

Convex temperature gradient inflection

Low resistivity, borehole enlargement 
Table 5. Transmissive intervals in borehole UE-25c \#2

[Features discussed briefly in this table are shown in detail on plate 2]

\begin{tabular}{|c|c|c|c|c|}
\hline $\begin{array}{l}\text { Depth } \\
\text { below land } \\
\text { surface } \\
\text { (feet) }\end{array}$ & Characteristics & $\begin{array}{l}\text { Intraborehole } \\
\text { flow } \\
\text { (gallons per } \\
\text { minute) }\end{array}$ & $\begin{array}{l}\text { Pump- } \\
\text { Ing dis- } \\
\text { charge } \\
\text { (per- } \\
\text { cent) }\end{array}$ & Supporting Informatlon \\
\hline $1,441-1,570$ & $\begin{array}{l}\text { Poor visibility to } 1,514 \mathrm{ft} \text {, but believed to be sparsely to moderately frac- } \\
\text { tured to } 1,552 \mathrm{ft} \text {. Large matrix permeability below } 1,539 \mathrm{ft} \text {. Known frac- } \\
\text { tures are vertical, northwest, north, and northeast-striking; two are open }\end{array}$ & $\geq 0.04$ down & $\mathbf{0}$ & $\begin{array}{l}\text { Low resistivity; convex temperature gradient } \\
\text { inflection at about } 1,465 \mathrm{ft} \text {, and concave tempera- } \\
\text { ture gradient inflection at about } 1,520 \mathrm{ft} \text {; borehole } \\
\text { enlargement and rugosity }\end{array}$ \\
\hline $1,624-1,634$ & Very fractured; fractures are shallow, north and northeast-striking & 0.01 in and & 0 & Very low resistivity, borehole enlargement \\
\hline $1,644-1,653$ & $\begin{array}{l}\text { Very fractured; fractures are shallow-vertical, diversely oriented, open at } \\
\text { intersections }\end{array}$ & down & $\mathbf{0}$ & $\begin{array}{l}\text { Very low resistivity, convex temperature gradient } \\
\text { inflection, borehole enlargement }\end{array}$ \\
\hline $1,672-1,673$ & Open parting at Calico Hills-Crater Flat contact & & 0 & Low resistivity, borehole enlargement \\
\hline $1,812-1,870$ & $\begin{array}{l}\text { Very fractured, with large matrix permeability; fractures are near vertical- } \\
\text { vertical, south and southeast-striking }\end{array}$ & $\begin{array}{l}0.10 \text { in and } \\
\text { down to maxi- } \\
\text { mum downward- } \\
\text { flow of } 0.15\end{array}$ & 0 & $\begin{array}{l}\text { Decrease to low resistivity concave temperature } \\
\text { gradient inflection }\end{array}$ \\
\hline $1,948-1,968$ & Moderately fractured(?). No known fractures because of poor visibility & 0.01 out & 0 & Low resistivity, borehole enlargement \\
\hline $2,045-2,093$ & $\begin{array}{l}\text { Poor visibility; could be sparsely to moderately fractured, although no frac- } \\
\text { tures were detected. Interval known to have large matrix permeability }\end{array}$ & & 0 & $\begin{array}{l}\text { Generally low resistivity, convex temperature gra- } \\
\text { dient inflection, substantial borehole enlargement }\end{array}$ \\
\hline $2,107-2,122$ & $\begin{array}{l}\text { Poor visibility, but believed to be moderately fractured. Known to have } \\
\text { large matrix permeability }\end{array}$ & 0.01 out & 0 & $\begin{array}{l}\text { Generally low resistivity, borehole enlargement } \\
\text { and rugosity }\end{array}$ \\
\hline $2,138-2,139$ & Open parting at Prow Pass-Bullfrog contact & & 7 & Low resistivity, borehole enlargement \\
\hline $2,252-2,267$ & $\begin{array}{l}\text { Very fractured; fractures, one of which is open, are near vertical-vertical, } \\
\text { south-striking }\end{array}$ & 0.01 out & 0 & Low resistivity \\
\hline $2,380-2,416$ & $\begin{array}{l}\text { Very fractured, with large matrix permeability; fractures, about a third of } \\
\text { which are open, are steep-vertical, mostly north and south-striking (also } \\
\text { northeast, east, southeast, and southwest-striking) }\end{array}$ & 0.04 out & 79 & $\begin{array}{l}\text { Resistivity trough, major convex temperature gra- } \\
\text { dient inflection, borehole enlargement }\end{array}$ \\
\hline $2,437-2,499$ & $\begin{array}{l}\text { Very fractured rock with thin intervals of unfractured rock; fractures mostly } \\
\text { are open, steep-vertical, south, southeast, southwest, and northwest-striking }\end{array}$ & 0.02 out & 14 & $\begin{array}{l}\text { Decrease to low resistivity, concave temperature } \\
\text { gradient inflection; minor borehole enlargement }\end{array}$ \\
\hline $2,691-2,694$ & $\begin{array}{l}\text { Very fractured; interval contains a single partly mineralized, vertical, south- } \\
\text { striking fracture, indicated on lithologic log to be a fault }\end{array}$ & Small loss(?) & 0 & Low resistivity \\
\hline $2,707-2,726$ & $\begin{array}{l}\text { Very fractured; fractures mostly are open, steep-vertical, southeast, south, } \\
\text { and southwest-striking }\end{array}$ & 20.03 out & 0 & $\begin{array}{l}\text { Low resistivity, major concave temperature gradi- } \\
\text { ent inflection, major borehole enlargement }\end{array}$ \\
\hline $2,749-2,789$ & $\begin{array}{l}\text { Very fractured; fractures, three of which are open, are steep-vertical, north } \\
\text { and south-striking }\end{array}$ & $\begin{array}{l}0.08 \text { out (chang- } \\
\text { ing from down- } \\
\text { ward to upward } \\
\text { at } 2,750 \mathrm{ft} \text { ) }\end{array}$ & 0 & $\begin{array}{l}\text { Low resistivity, convex temperature gradient } \\
\text { inflection, borehole enlargement and rugosity }\end{array}$ \\
\hline $2,789-2,797$ & $\begin{array}{l}\text { Very fractured; fractures mostly are shallow-steep, south-striking; three } \\
\text { open fractures at 2,793-2,795 ft comprise the Paintbrush Canyon Fault zone }\end{array}$ & $\begin{array}{l}\geq 0.05 \text { in to } \max \text { - } \\
\text { imum upward } \\
\text { flow }\end{array}$ & 0 & Low resistivity \\
\hline $2,891-2,942$ & $\begin{array}{l}\text { Very fractured; fractures, four of which are open, are steep-vertical, } \\
\text { diversely oriented }\end{array}$ & Small up(?) & 0 & $\begin{array}{l}\text { Low resistivity, concave temperature gradient } \\
\text { inflection }\end{array}$ \\
\hline $2,942-2,961$ & $\begin{array}{l}\text { Sparsely fractured; interval known to contain two shallow, south-striking } \\
\text { fractures, one of which is open }\end{array}$ & Small up(?) & 0 & Low resistivity \\
\hline
\end{tabular}


Table 6. Transmissive intervals in borehole UE-25c \#3

[Features discussed briefly in this section are shown in detail on plate 3]

\begin{tabular}{|c|c|c|c|c|}
\hline $\begin{array}{l}\text { Depth } \\
\text { below land } \\
\text { surface } \\
\text { (feet) }\end{array}$ & Characteristlcs & $\begin{array}{l}\text { Intraborehole flow } \\
\text { (gallons per } \\
\text { minute) }\end{array}$ & $\begin{array}{l}\text { Pump- } \\
\text { Ing dis- } \\
\text { charge } \\
\text { (per- } \\
\text { cont) }\end{array}$ & Supporting Information \\
\hline $1,414-1,483$ & $\begin{array}{l}\text { Sparsely to moderately fractured. Known fractures are steep-near vertical, north and } \\
\text { northwest-striking. Unfractured rock apparently transmits water }\end{array}$ & Small down(?) & 0 & Low resistivity; borehole enlargement \\
\hline $1,483-1,522$ & $\begin{array}{l}\text { Moderately to very fractured; large matrix permeability; fractures, mostly open to } \\
1,510 \mathrm{ft} \text {, are shallow-vertical, north, south, and southwest-striking. Water apparently } \\
\text { is transmitted by fractures and matrix }\end{array}$ & $\begin{array}{l}\geq 0.10 \text { out (any } \\
\text { downward flow } \\
\text { and all remaining } \\
\text { upward flow lost) }\end{array}$ & $\mathbf{0}$ & $\begin{array}{l}\text { Low resistivity, concave temperature } \\
\text { gradient inflection, borehole enlarge- } \\
\text { ment }\end{array}$ \\
\hline $1,522-1,586$ & $\begin{array}{l}\text { Sparsely to moderately fractured, large matrix permeability; fractures are shallow- } \\
\text { vertical, northeast, east, and south-striking. Water apparently transmitted by frac- }\end{array}$ & 0.04 in and up & 0 & $\begin{array}{l}\text { Low resistivity, convex temperature } \\
\text { gradient reflection }\end{array}$ \\
\hline
\end{tabular}

1,615-1,640 Very fractured, large matrix permeability below $1,629 \mathrm{ft}$, open parting at Calico Hills-Crater Flat contact; fractures, mostly open 1,622-1,625 ft, are shallow-near vertical, diversely oriented. Most flow probably is through open fractures and parting

1,640-1,674 Sparsely fractured to $1,666 \mathrm{ft}$, moderately fractured below; large matrix permeability; fractures are near vertical, east, south, and southwest-striking. Water apparently transmitted by fractures and matrix

1,846-1,865 Moderately fractured, large matrix permeability; fractures are near vertical-vertical east, southeast, and south-striking. Water apparently transmitted by fractures and matrix

1,865-1,950 Sparsely to moderately fractured(?): No fractures detected, but matrix permeability is too small for unfractured rock to be transmissive

2,050-2,132 Sparsely fractured to $2,116 \mathrm{ft}$, very fractured below; large matrix permeability throughout. Fractures are shallow-near vertical, west and south-striking. Water apparently transmitted by matrix above $2,116 \mathrm{ft}$, fractures and matrix below

2,200-2,215 Moderately fractured(?), large matrix permeability; although no fractures detected, sharp peak on caliper log implies presence of one or more. Water probably transmitted by fractures and matrix

2,374-2,381 Very fractured, large matrix permeability; fractures, one of which is open, are mostly near vertical-vertical, southeast-striking

2,421-2,478 Very fractured; fractures are open, near vertical-vertical, south-striking

0.01 in and up

Small gain(?)

0 Very low resistivity, borehole enlargement to about 32 inches

Small loss(?)

$\leq 0.01$ out Low resistivity, borehole enlargement

Low resistivity, minor borehole enlargement

0 Low resistivity, concave temperature gradient inflection

0 Low resistivity, borehole enlargement

0.02 out

0 Low resistivity, concave temperature gradient inflection, borehole enlargement

1.72 out

1.7 out

Convex temperature gradient inflection, borehole enlargement

55 Low resistivity, borehole enlargement to $2,450 \mathrm{ft}$

0.5 out

Small loss(?)

3 Low resistivity, borehole enlargement

2,503-2,527 Very fractured; fractures, two of which are open, are vertical, south-striking

2,535-2,665 Sparsely to moderately fractured(?), with large matrix permeability below

2,610 ft.Interval known to contain an open, shallow, north-striking fracture and a near vertical south-striking fracture; other fractures implied by sharp caliper peaks. Water probably transmitted through open fractures and matrix 
Table 6. Transmissive intervals in borehole UE-25C \#3 --Continued

\begin{tabular}{|c|c|c|c|c|}
\hline $\begin{array}{l}\text { Depth } \\
\text { below land } \\
\text { surface } \\
\text { (feet) }\end{array}$ & Characteristics & $\begin{array}{l}\text { Intraborehole flow } \\
\text { (gallons per } \\
\text { minute) }\end{array}$ & $\begin{array}{l}\text { Pump- } \\
\text { Ing dis- } \\
\text { charge } \\
\text { (por- } \\
\text { cont) }\end{array}$ & Supporting Informatlon \\
\hline $2,685-2,755$ & $\begin{array}{l}\text { Moderately to very fractured; fractures, two of which are open, are shallow-steep, } \\
\text { northeast, southwest, west, northwest, and north-striking }\end{array}$ & $\begin{array}{l}\text { Estimated small } \\
\text { gain to maximum } \\
\text { upward flow of } \\
>4.0\end{array}$ & $\mathbf{0}$ & $\begin{array}{l}\text { Low resistivity, borehole enlargement } \\
\text { around open fractures at } 2,685 \text { and } \\
2,703 \mathrm{ft}\end{array}$ \\
\hline $2,758-2,851$ & $\begin{array}{l}\text { Very fractured rock, including the Paintbrush Canyon Fault zone at } 2,820-2,825 \mathrm{ft} \text {, } \\
\text { separated by thin intervals of unfractured rock; fractures four of which are open, are } \\
\text { shallow-vertical, mostly north, south, and southwest-striking }\end{array}$ & 2.0 in and up & 25 & $\begin{array}{l}\text { Low resistivity, convex temperature } \\
\text { gradient inflection, borehole enlarge- } \\
\text { ment to about } 22 \text { inches below } 2,830 \mathrm{ft}\end{array}$ \\
\hline $2,884-2,887$ & Very fractured; fractures are shallow-steep, north and northwest-striking & 0.1 in and up & $\mathbf{0}$ & Low resistivity, borehole enlargement \\
\hline $2,899-2,910$ & $\begin{array}{l}\text { Very fractured; fractures are shallow-steep, mostly west, northwest, and north- } \\
\text { striking }\end{array}$ & 0.1 in and up & $\mathbf{0}$ & $\begin{array}{l}\text { Concave temperature gradient inflec- } \\
\text { tion }\end{array}$ \\
\hline $2,923-2,945$ & Moderately fractured; fractures are shallow-vertical, mostly north and west-striking & 0.1 in and up & $\mathbf{0}$ & $\begin{array}{l}\text { Low resistivity, convex temperature } \\
\text { gradient inflection }\end{array}$ \\
\hline $2,950-3,000$ & $\begin{array}{l}\text { Moderately fractured(?); extent of fracturing uncertain because interval is concealed } \\
\text { by cable and borehole collapse }\end{array}$ & 1.7 in and up & 0 & Low resistivity \\
\hline
\end{tabular}




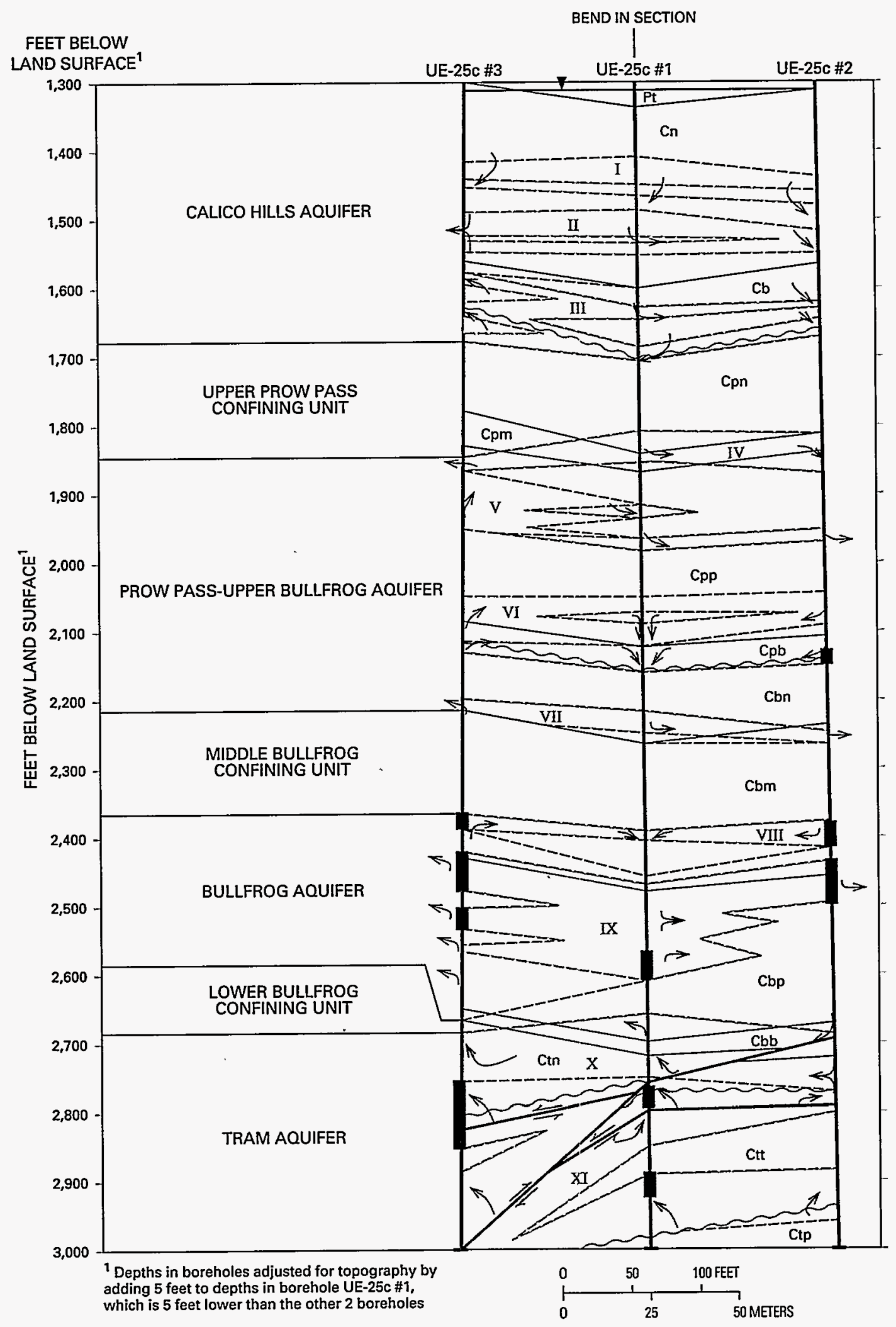

Figure 7A. Hydrogeologic section of the c-hole complex.

18 Results and Interpretation of Preliminary Aquifer Tests in Boreholes UE-25c \#1, UE-25c \#2, and UE-25c \#3, Yucca Mountain, Nye County, Nevada 
EXPLANATION

Pt PAINTBRUSH TUFF, TOPOPAH SPRING MEMBER

TUFFS AND LAVAS OF CALICO HHLS

\begin{tabular}{|c|c|}
\hline $\mathrm{Cn}_{\mathrm{n}}$ & NONWEDED \\
\hline $\mathrm{Cb}$ & BEDDED \\
\hline
\end{tabular}

CRATER FLAT TUFF

PROW PASS MEMBER

\begin{tabular}{|c|c|}
\hline$C_{p n}$ & NONWE DED TO PARTIALLY WELDED \\
\hline $\mathrm{Cpm}$ & MODERATELY WEDED \\
\hline Cpp & PARTIALLY WEL DED TO NONWEI DED \\
\hline Cpb & BEDDED \\
\hline
\end{tabular}

\begin{tabular}{|c|c|}
\hline Cbn & NONWEL DED TO PARTIALLY WEIDED \\
\hline $\mathrm{Cbm}$ & MODERATELY TO DENSELY WEIDED \\
\hline Cbp & PARTIALLY WELDED TO NONWEI DED \\
\hline Cbb & BEDDED \\
\hline
\end{tabular}

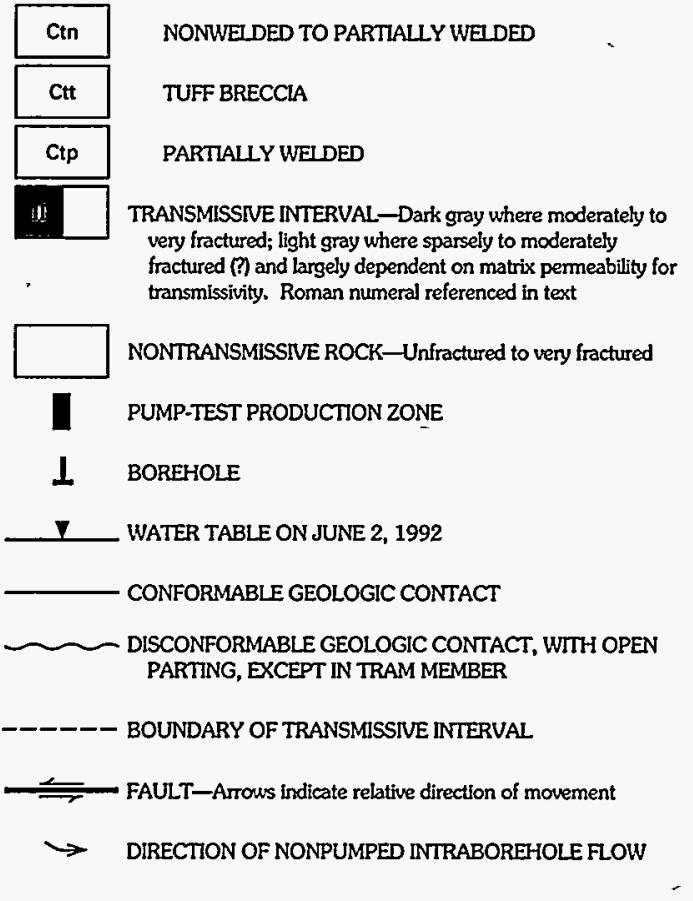

Figure 7B. Hydrogeologic section of the c-hole complex. 
open, are shallow to vertical and diversely oriented. The upper part of the aquifer (transmissive interval $\mathrm{I}$ ) is characterized by small to moderate downflows from the water table. In the middle part of the aquifer (transmissive intervals II and III), all downward flow in borehole UE-25c \#3, all remaining upward flow from lower in borehole UE-25c \#3, and about a third of the downwardflow in borehole UE-25c \#1 are lost through fractures and the rock matrix; some of this water flows into borehole UE-25c \#2. At the bottom of the aquifer, small upflows and downflows enter the c-holes through a parting at the contact between the tuffs and lavas of Calico Hills and the Crater Flat Tuff.

\section{Prow Pass - Upper Bullfrog Aquifer}

The Prow Pass - upper Bullfrog aquifer extends from about $1,800 \mathrm{ft}$ to about $2,270 \mathrm{ft}$ below land surface and probably either is unconfined or is a fissure-block aquifer. It consists of four relatively thin zones of moderately (?) to very fractured rock separated by thin to thick intervals of unfractured to sparsely fractured rock, some of which contain large matrix permeability (fig. 7). Fractures, some of which are open, are shallow to vertical and diversely oriented, although many are north-or south-striking. A parting at the contact between the Prow Pass and Bullfrog Members of the Crater Flat Tuff occurs near the bottom of the aquifer. In the upper part of the aquifer (transmissive intervals IV and V), a small outflow from borehole UE-25c \#3 is transmitted toward borehole UE-25c \#1, and a small outflow from borehole UE-25c \#1 is transmitted toward borehole UE-25c \#2. Lower in this part of the aquifer, these inflows leave boreholes UE-25c \#1 and UE-25c \#2 through fractures. In the middle part of the aquifer (transmissive interval VI), small outflows from boreholes UE-25c \#2 and UE-25c \#3 are transmitted by fractures, the rock matrix, and the parting at the Prow Pass - Bullfrog contact toward borehole UE-25c \#1. At the bottom of the aquifer (transmissive interval VII), small outflows to fractures occur in all of the c-holes. Seven percent of the discharge from borehole UE-25c \#2 during a pumping test in March 1984 came from this aquifer.

\section{Bullfrog Aquifer}

The Bullfrog aquifer extends from about 2,370 to $2,660 \mathrm{ft}$ below land surface and is confined by more than $100 \mathrm{ft}$ of overlying unfractured to sparsely fractured, moderately to densely welded tuff (fig. 7). The aquifer consists mostly of moderately to very fractured rock with thin intervals of unfractured to sparsely fractured rock, but the lower $50 \mathrm{ft}$ of the aquifer in borehole
UE-25c \#3 is sparsely to moderately fractured. The upper part of the aquifer (transmissive interval VIII) contains large matrix permeability. Fractures, most of which are open, are shallow to vertical, and diversely oriented. In the upper part of the aquifer, small to large outflows from boreholes UE-25c \#2 and UE-25c \#3 are transmitted toward borehole UE-25c \#1. In the lower part of the aquifer (transmissive interval IX), all downward flow and all remaining upward flow from lower in borehole UE-25c \#1 are lost through fractures; small to large outflows from boreholes UE-25c \#2 and UE-25c \#3 occur, as well. Sixty-four percent of the discharge from a pumping test in borehole UE-25c \#1 in September 1983, 93 percent of the discharge from a pumping test in borehole UE-25c \#2 in March 1984, and 75 percent of the discharge from a pumping test in borehole UE-25c \#3 in May-June 1984 came from this aquifer.

\section{Tram Aquifer}

The Tram aquifer extends from about $2,660 \mathrm{ft}$ below land surface to the bottom of the c-holes and is confined. However, leakage occurs from two faults that transect this aquifer. The aquifer consists almost entirely of moderately to very fractured rock (fig. 7). Fractures, many of which are open, are shallow to vertical and diversely oriented. At the top of the aquifer (transmissive interval X), all downward flow and all remaining upward flow from lower in the borehole are lost from borehole UE-25c \#2 and are transmitted toward boreholes UE-25c \#1 and UE-25c \#3. In the lower part of the aquifer (transmissive interval XI), small to large upward flows enter the c-holes. Thirtysix percent of the discharge from a pumping test in borehole UE-25c \#1 in September 1983 and 25 percent of the discharge from a pumping test in borehole UE-25c \#3 in May-June 1984 came from this aquifer.

\section{FLUID-INJECTION TESTS}

Twenty-six fluid-injection tests were conducted in the c-holes in 1983 and 1984. In October 1983, 16 falling-head (slug) tests and nine pressure-injection tests were conducted in borehole UE-25c \#1. In October 1984, a constant-head injection test was conducted in borehole UE-25c \#2 using boreholes UE-25c \#1 and UE-25c \#3 as observation wells. The constant-head test, soon after it began, developed into a constant-flux test and is discussed later in this report with pumping tests conducted in the c-holes. 


\section{Falling-Head Tests}

Falling-head tests conducted in borehole UE-25c \#1 are listed in table 7, which indicates that test intervals were successively reduced from 160 to 40 to $22 \mathrm{ft}$, except near the top and bottom of the borehole, where test interval thicknesses were determined partly by the bottom of the concrete and the bottom of the borehole. As shown in figure 8, tests intervals were isolated by TAM International inflatable packers, monitored primarily by contractor-supplied Kuster and Sperry-Sun pressure and temperature gauges above, between, and below the packers, and monitored secondarily by a USGS-supplied Bell and Howell pressure-transducer suspended inside the 2.26-in.-inside diameter plastic riser pipe above the packer string. For all tests except test 1 , the transducer was set at $1,370 \mathrm{ft}$ below the top of the riser pipe; for test 1 , it was set at $1,330 \mathrm{ft}$ below the top of the pipe.

According to Devin L. Galloway (USGS, oral commun., 1993), the contractor-supplied gauges, with pressure ranges of 0 to $2,150 \mathrm{lb} / \mathrm{in}^{2}{ }^{2}$ and 0 to $5,000 \mathrm{lb} / \mathrm{in}^{2}{ }^{2}$ (Tam International, written commun., 1983), were insensitive to small changes in head that are common to aquifer tests. Moreover, because of a recording interval of $2 \mathrm{~min}$, these gauges missed the initial head in some tests, and in very permeable intervals, the gauges missed most or all of the head recovery. The USGS-supplied pressure transducer, with a pressure range of 0 to $500 \mathrm{lb} / \mathrm{in}^{2}{ }^{2}$ and a minimum recording interval of eight seconds, was considered more reliable for data collection and analysis than the contractor-supplied gauges. Consequently, only the pressure-transducer data for the falling-head tests were analyzed.

An additional problem with the design of the falling-head tests was the large column of water injected into borehole UE-25c \#1 during the tests. As indicated in table 7, initial injected heads in these tests ranged from 592 to $1,022 \mathrm{ft}$ above the static water level, averaging about $700 \mathrm{ft}$. Galloway (USGS, written commun., 1986) reported that calculations for a representative test conducted in a permeable zone indicate that a head loss of 35 to 40 percent probably occurred during the falling-head tests as a result of friction between the injected water as it descended and the riser pipe. Although early-time recovery data could have been affected by any initial head loss to friction, later recovery data probably would not have been affected. Consequently, the later-time recovery data were emphasized in analyzing these tests.

The commonly used method for analyzing falling-head tests, in a confined aquifer, is that of Cooper and others (1967), which assumes radial flow to a fully penetrating well in a homogeneous, isotropic, compressible aquifer. Reed (1980) presents type curves of the well function for the analytical solution of Cooper and others (1967). As pointed out by Cooper and others (1967), matching data curves with the type curves can provide a good determination of transmissivity, whereas the determination of storativity is not reliable because of the similar shape of the type curves. Barker and Black (1983) indicate that the solution of Cooper and others (1967) can be applied successfully to formations with very low storativity and to fractured rock, provided that there is no exchange of water between fractures and the rock matrix and that fracture apertures are not changed by the pressure of the injected water column. However, Barker and Black (1983) state that even where water is derived from fractures and the rock matrix, a situation commonly termed a "dual-porosity" aquifer, transmissivity determined by the method of Cooper and others (1967) will be underestimated by a factor of no more than 2-3. This potential error generally would be considered insignificant in a complicated hydrogeologic environment, such as the c-hole complex, where one might expect transmissivity calculations to be within an order of magnitude of actual values. Barker and Black (1983) cautioned against using the method of Cooper and others (1967) to determine storativity in a dual-porosity aquifer, because the method can underestimate storativity by a factor of as large as 0.000001 . Because of large potential error, storativity was not determined from the falling-head tests in borehole UE-25c \#1.

In the solution of Cooper and others (1967), values of the ratio of injected head at time $t$ to initial injected head $\left(\mathrm{H} / \mathrm{H}_{\mathrm{o}}\right)$ are plotted against time elapsed since the injection of fluid occurred. A match between the data curve and a type curve plot of $\mathrm{H} / \mathrm{H}_{0}$ as a function of $\beta=T t / r_{c}{ }^{2}$ gives a value of $\alpha=r_{s}{ }^{2} / r_{c}{ }^{2} \times S, B$, and time, where,

$$
\begin{aligned}
T= & \text { transmissivity }\left(\mathrm{L}^{2} / \mathrm{T}\right) ; \\
r_{c}= & \text { radius of casing (plastic rise } \\
& \text { UE-25c \#1) in which water } \\
& (\mathrm{L}) ; \\
r_{s}= & \text { radius of open hole (L); } \\
t= & \text { time (T); and } \\
S= & \text { storativity (dimensionless). }
\end{aligned}
$$$$
r_{c}=\text { radius of casing (plastic riser pipe in }
$$$$
\text { UE-25c \#1) in which water level fluctuates }
$$

Transmissivity is found by picking a match point where $B=1$ and solving the equation:

$$
T=r_{c}^{2} / t
$$

On the basis of the solution of Cooper and others (1967), falling-head tests in borehole UE-25c \#1 indicated transmissivity values for tested intervals that 
Table 7. Results of falling-head tests conducted in borehole UE-25c \#1, October 6-12, 1983

\begin{tabular}{|c|c|c|c|c|c|c|c|}
\hline $\begin{array}{c}\text { Test } \\
\text { num- } \\
\text { ber }\end{array}$ & $\begin{array}{l}\text { Test Interval } \\
\text { depth } \\
\text { (feet) }\end{array}$ & Geologic description of test Interval & $\begin{array}{l}\text { Static } \\
\text { water } \\
\text { level } \\
\text { (feet } \\
\text { below } \\
\text { land } \\
\text { surface) }\end{array}$ & $\begin{array}{c}\text { Initlal } \\
\text { head } \\
\text { above } \\
\text { static } \\
\text { water } \\
\text { level } \\
\text { (foet) }\end{array}$ & $\begin{array}{c}\text { Duration } \\
\text { of } \\
\text { recovery } \\
\text { (minutes) }\end{array}$ & $\begin{array}{l}\text { Trans- } \\
\text { missivity } \\
\text { (foot } \\
\text { square } \\
\text { por day) }\end{array}$ & $\begin{array}{c}\text { Hydraullc } \\
\text { conduc- } \\
\text { tlvity } \\
\text { (foet per } \\
\text { day) }\end{array}$ \\
\hline 1 & $1,371-1,515$ & $\begin{array}{l}\text { Unfractured to sparsely fractured, nonwelded and bedded tuff with thin intervals that are } \\
\text { moderately fractured }\end{array}$ & 1,314 & 649 & 41 & 20 & 0.1 \\
\hline 2 & $1,685-1,845$ & Unfractured to very fractured, nonwelded to moderately welded tuff & 1,313 & 638 & 84 & 10 & 0.07 \\
\hline 3 & $1,865-2,025$ & Unfractured to very fractured, nonwelded to partially welded tuff & 1,313 & 699 & 243 & 0.8 & 0.005 \\
\hline 4 & $2,050-2,210$ & Unfractured to very fractured, bedded and nonwelded to partially welded tuff & 1,313 & 728 & 422 & 10 & 0.08 \\
\hline 6 & $2,610-2,770$ & Unfractured to very fractured, nonwelded to partially welded tuff & 1,314 & 656 & 100 & 8 & 0.05 \\
\hline 7 & $2,780-2,995$ & Very fractured tuff breccia and tuff within unfractured intervals & 1,312 & 750 & 13 & 40 & 0.2 \\
\hline 10 & $1,805-1,845$ & Very fractured, nonwelded to moderately welded tuff & 1,314 & 705 & 111 & 4 & 0.1 \\
\hline 12 & $1,900-1,940$ & Unfractured and very fractured, nonwelded to partially welded tuff & 1,312 & 666 & 281 & 0.3 & 0.008 \\
\hline 15 & $2,555-2,595$ & Moderately to very fractured, nonwelded to partially welded tuff & 1,314 & 784 & 2.75 & 80 & 2 \\
\hline 16 & $2,746-2,786$ & Very fractured, nonwelded to partially welded tuff and tuff breccia & 1,313 & 592 & 12 & 20 & 0.5 \\
\hline 17 & $2,818-2,858$ & Unfractured and very fractured tuff breccia & 1,314 & 792 & 70 & 10 & 0.3 \\
\hline .18 & $2,880-2,920$ & Very fractured tuff breccia & 1,313 & 822 & 41 & 20 & 0.5 \\
\hline 19 & $2,930-2,995$ & Unfractured and very fractured tuff breccia and partially welded tuff & 1,314 & 1,022 & 116 & 5 & 0.08 \\
\hline 20 & $2,445-2,467$ & Moderately to very fractured, moderately to densely welded tuff & 1,313 & 683 & 87 & 9 & 0.4 \\
\hline 21 & $2,476-2,498$ & Very fractured, partially to densely welded tuff & 1,314 & 666 & 35 & 10 & 0.6 \\
\hline 26 & $2,607-2,995$ & Mostly moderately to very fractured, nonwelded to partially welded tuff and tuff breccia & 1,314 & 869 & 12.5 & 50 & 0.1 \\
\hline
\end{tabular}




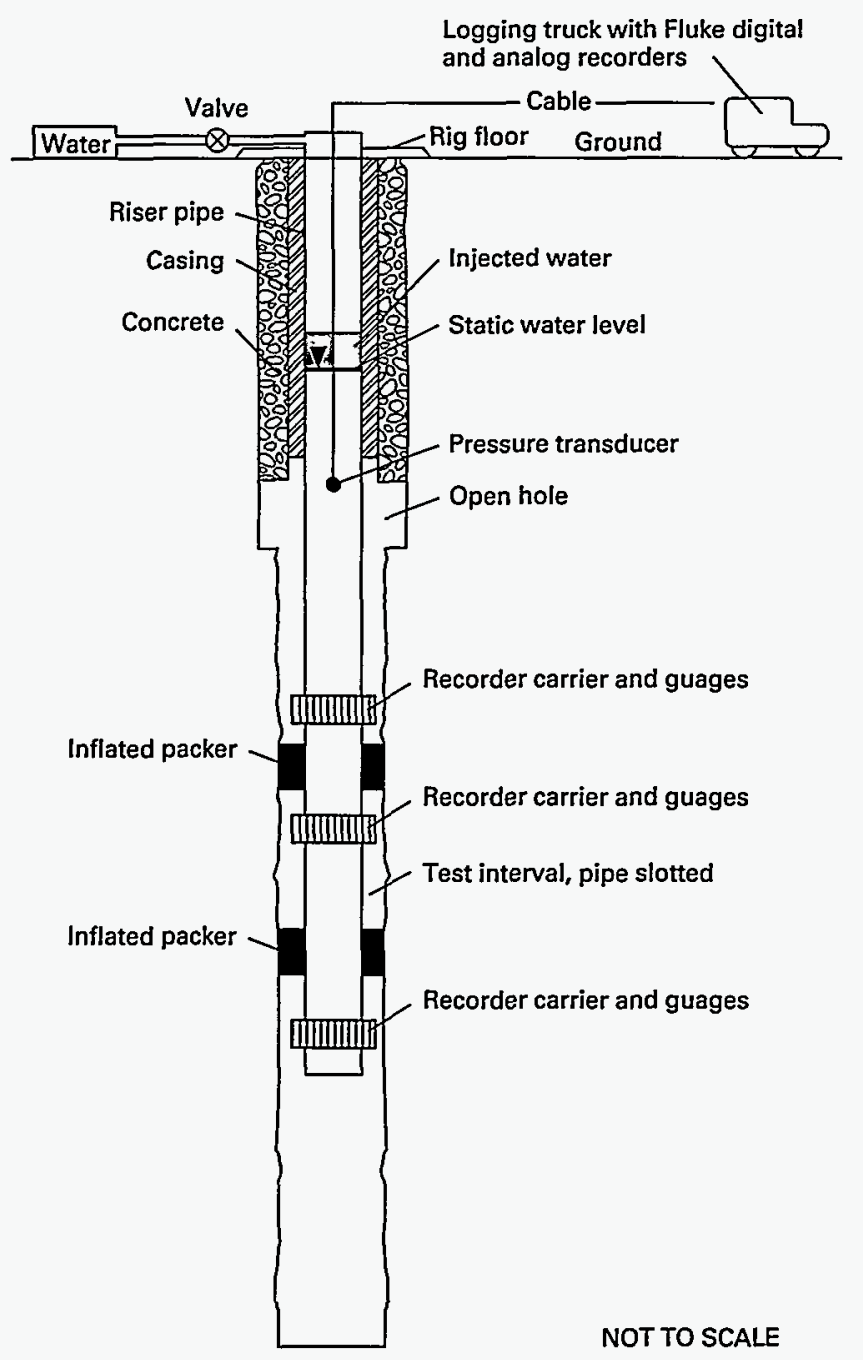

Figure 8. Design configuration of falling-head tests in borehole UE-25c \#1, October 1983. 
ranged from 0.3 to $80 \mathrm{ft}^{2} / \mathrm{d}$ (table 7). Assuming that head is dissipated uniformly throughout tested intervals, and not through preferred pathways, such as fractures and partings, then dividing transmissivity by test interval thickness provides estimates of hydraulic conductivity for the tested intervals. Estimated values of hydraulic conductivity from the falling-head tests, range from 0.005 to $2 \mathrm{ft} / \mathrm{d}$ (table 7 and fig. 9).

Values of transmissivity and hydraulic conductivity calculated using the method of Cooper and others (1967) are considered reasonable because:

1. In all tests, there was fair to good agreement between data curves and type curves. There was no systematic improvement in curve matching for intervals with less fracturing and, presumably, more dependence on matrix flow (fig. 10). Therefore, one can conclude that the presence of fractures in a test interval generally did not invalidate the fundamental assumption of radial flow through a homogeneous, isotropic aquifer.

2 . In the three sections of the borehole where multiple tests were conducted, 1,685 to $1,845 \mathrm{ft}$, 1,865 to $2,025 \mathrm{ft}$, and 2,607 to $2,995 \mathrm{ft}$, tests of successively smaller intervals produced successively smaller values of transmissivity, the sum of which did not exceed the transmissivity of the larger test interval (fig. 10). Transmissivity is additive and should increase with increasing test-interval thickness.

One problem common to all of the falling-head tests conducted in borehole UE-25c \#1 is the small to large divergence between the late-time recovery data and the tail of the type curve to which the data curve was matched (fig. 9). Analytical solutions invoking different conceptual flow models than that of Cooper and others (1967) were tried to provide more precise determinations of transmissivity (Devin L. Galloway, USGS, written commun., 1986). A linear flow model, which simulates flow in and perpendicular to fracture planes, produced a poorer solution because type curves are much flatter than those of Cooper and others (1967). Imposing a linear or radial constant-head boundary at some variable distance from borehole UE-25c \#1, simulating radial flow through a borehole skin (although not justified by the drilling technique), or considering spherical flow through the test interval, all produced type curves and tails steeper than those of Cooper and others (1967), but less steep than the data curves. None of the alternative analytical solutions were considered substantially more accurate or con- ceptually more realistic than the method of Cooper and others (1967). Consequently, calculations using only the method of Cooper and others (1967) are presented in this report.

\section{Pressure-Injection Tests}

Pressure-injection tests conducted in borehole UE-25c \#1 are listed in table 8, which indicates that test intervals were 22,40 , or $160 \mathrm{ft}$. Some of the tests were planned for intervals thought to have small permeability (Devin L. Galloway, USGS, oral commun., 1993), but most of the tests were changed from falling-head tests after a few minutes of extremely slow gravity drainage (USGS, unpublished log book for borehole UE-25c \#1). Four of the tests could not be analyzed because of apparent mechanical problems and insufficient or unreliable data.

The pressure-injection tests were designed similarly to the falling-head tests (fig. 8), except that a valve in the water line was closed during the pressureinjection tests to isolate the test interval from atmospheric pressure. With the system pressurized (shut in), the pressure transducer used in the falling-head tests would have no hydraulic connection to the test interval and, therefore, could not be used (see fig. 8). The Sperry-Sun gauge, which provided digital output at two-minute intervals, produced the primary record for the pressure-injection tests. The procedure for the pressure-injection tests (Neuzil, 1982) consisted of the following steps:

1. The valve in the water line was opened, and a slug of water was released into the borehole;

2. The test interval was shut in by closing the valve in the water line;

3. Pressure decay in the test interval was monitored until pressure was constant or nearly constant;

4. The control valve was opened briefly, and another slug of water was released into the borehole;

5. The control valve was closed, again shutting in the test interval;

6. Pressure in the test interval again was allowed to decay to a constant or nearly constant level; and

7. The control valve was opened, and pressure on the system was released.

The pressure-injection tests were analyzed by the method of Bredehoeft and Papadopulos (1980), as 


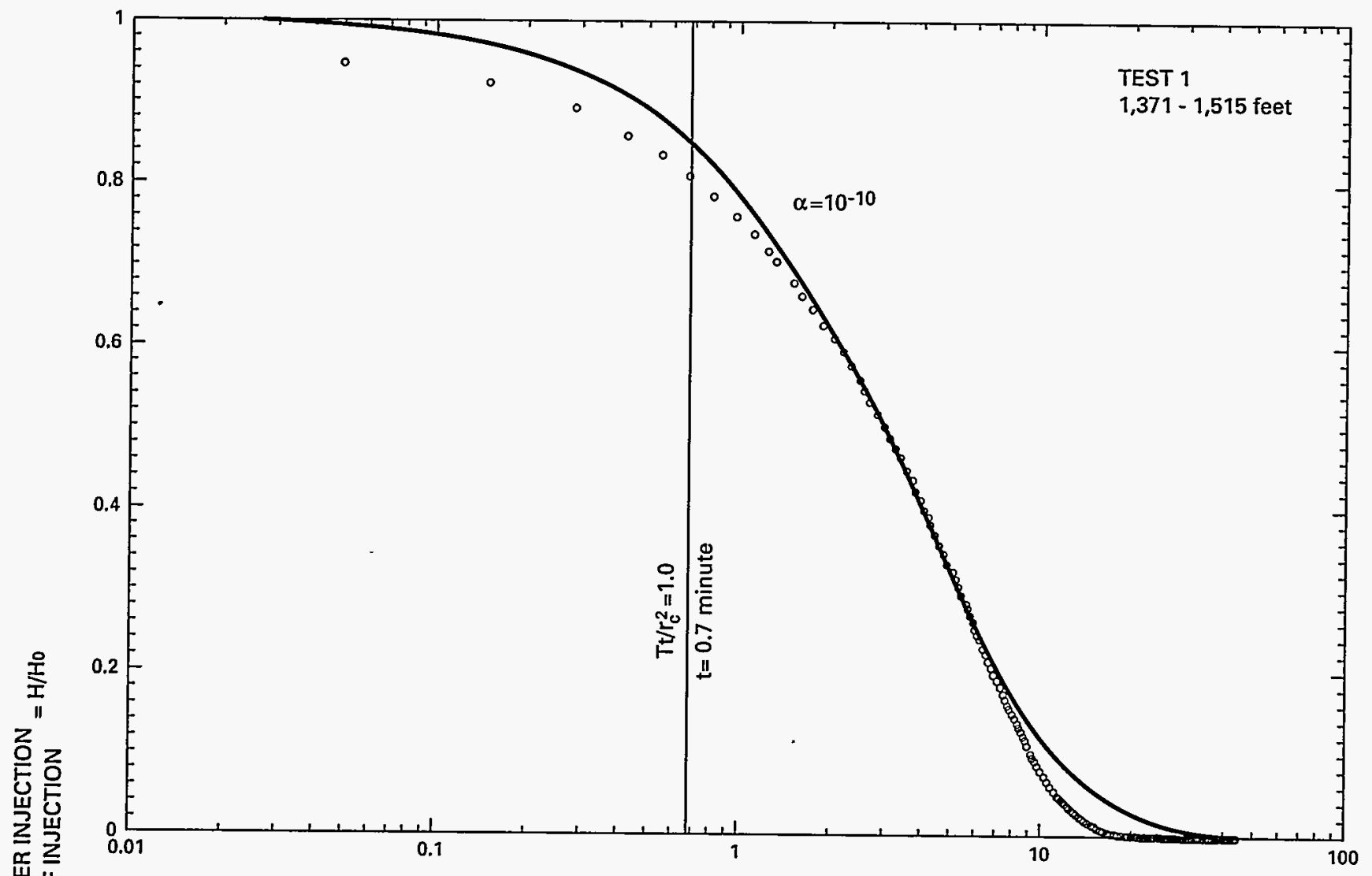

崖

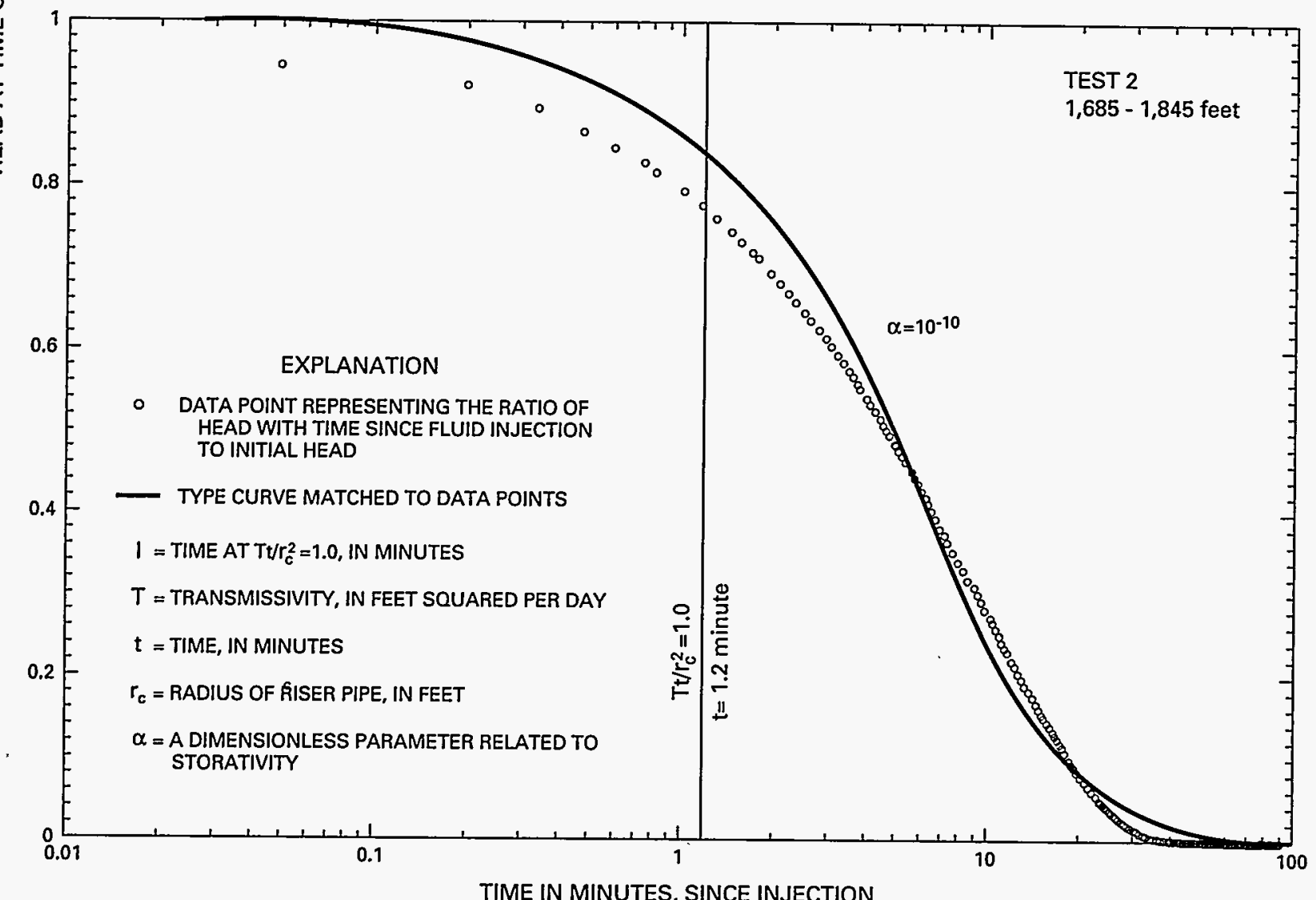

Figure 9A. Analyses of falling-head tests in borehole UE-25c \#1, October 1983, assuming an infinite, homogeneous, isotropic, confined aquifer (symbols on plots explained in text). 


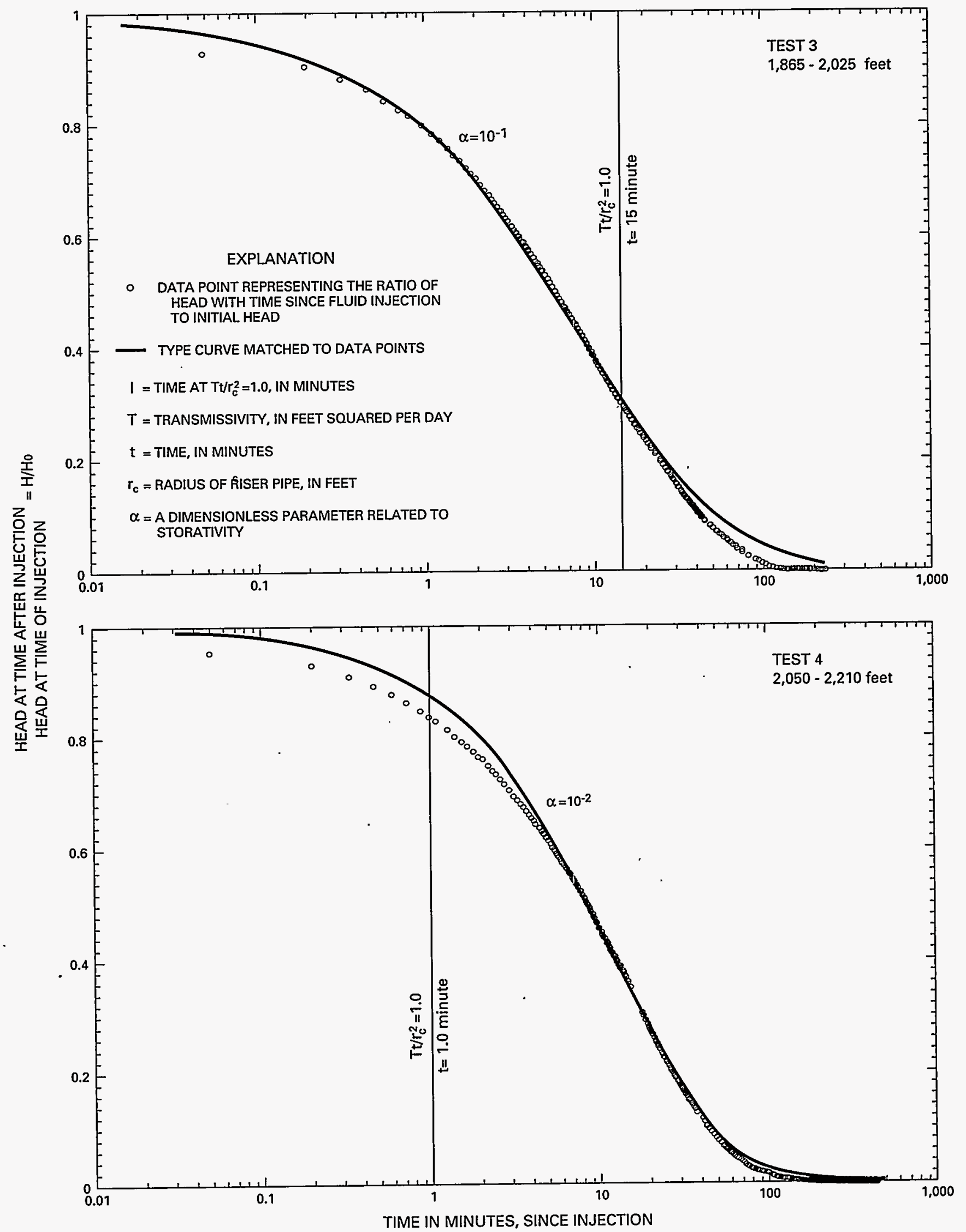

Figure 9B. Analyses of falling-head tests in borehole UE-25C \#1, October 1983, assuming an infinite, homogeneous, isotropic, confined aquifer (symbols on plots explained in text).

26 Results and Interpretation of Preliminary Aquifer Tests in Boreholes UE-25c \#1, UE-25c \#2, and UE-25c \#3, Yucca Mountaln, Nye County, Nevada 


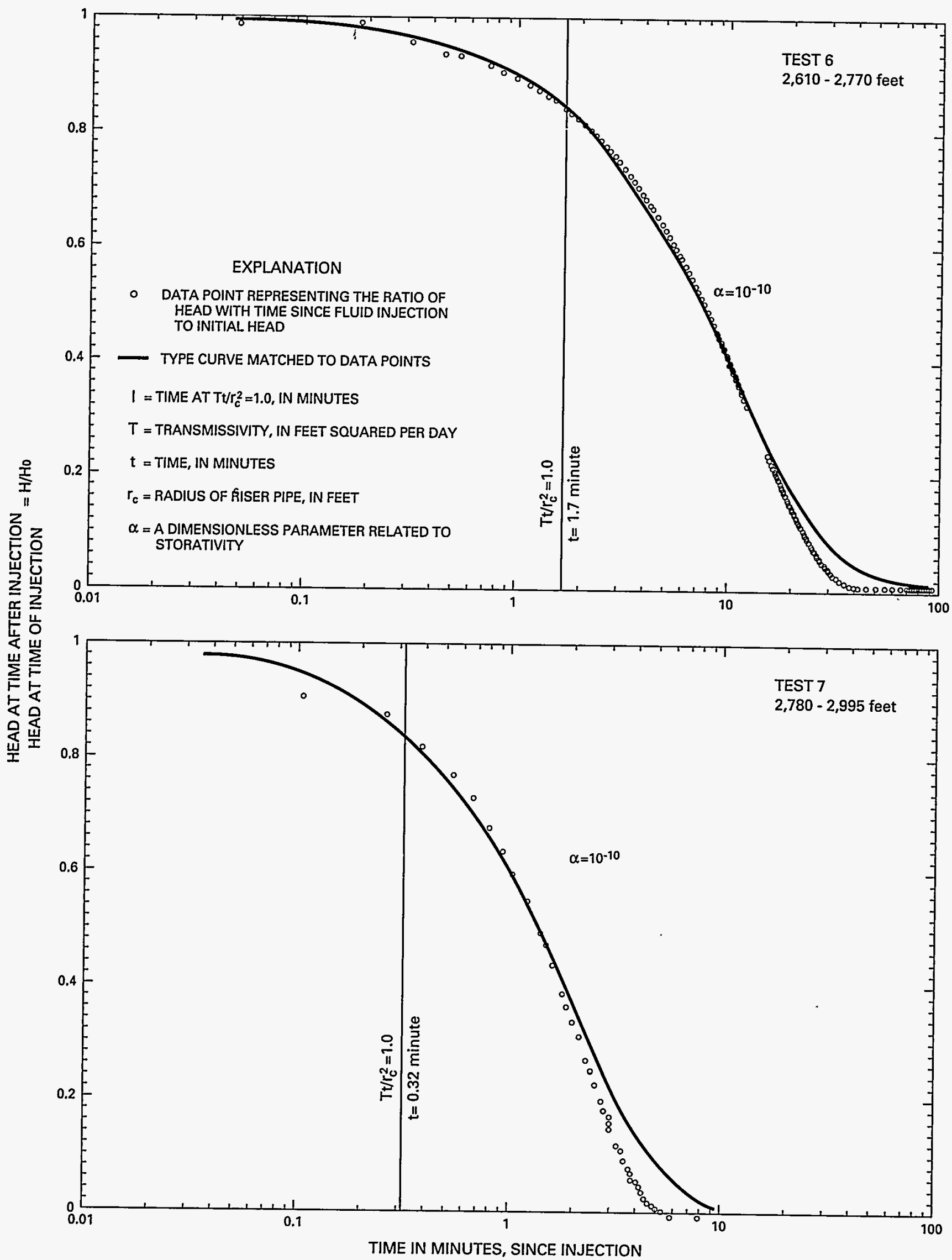
Figure 9C. Analyses of falling-head tests in borehole UE-25c \#1, October 1983, assuming an infinite, homogeneous, isotropic,
confined aquifer (symbols on plots explained in text). 


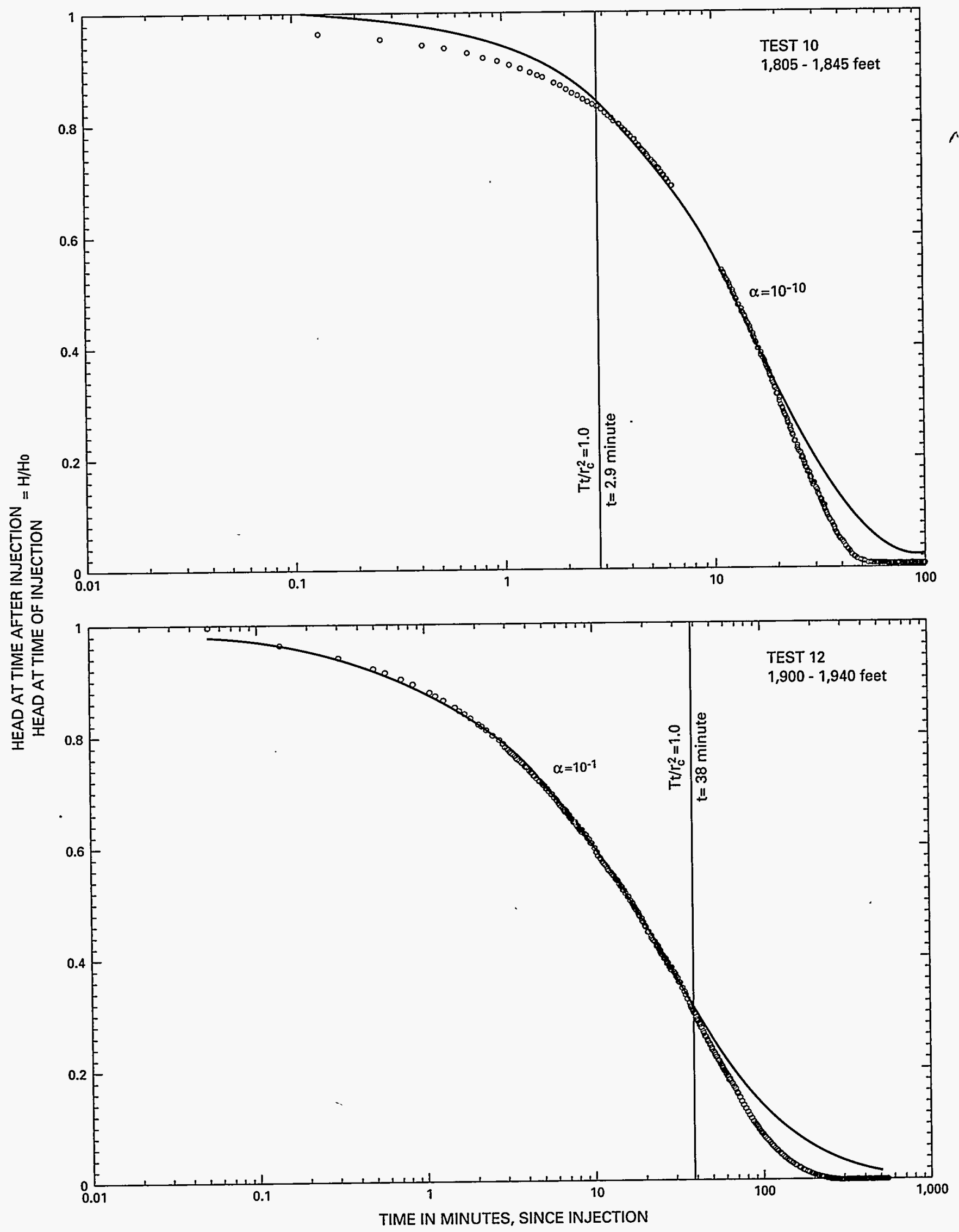

Figure 9D. Analyses of falling-head tests in borehole UE-25C \#1, October 1983, assuming an infinite, homogeneous, isotropic, confined aquifer (symbols on plots explained in text).

28 Results and Interpretation of Preliminary Aquifer Tests in Boreholes UE-25c \#1, UE-25c \#2, and UE-25c \#3, Yucca Mountain, Nye County, Nevada 


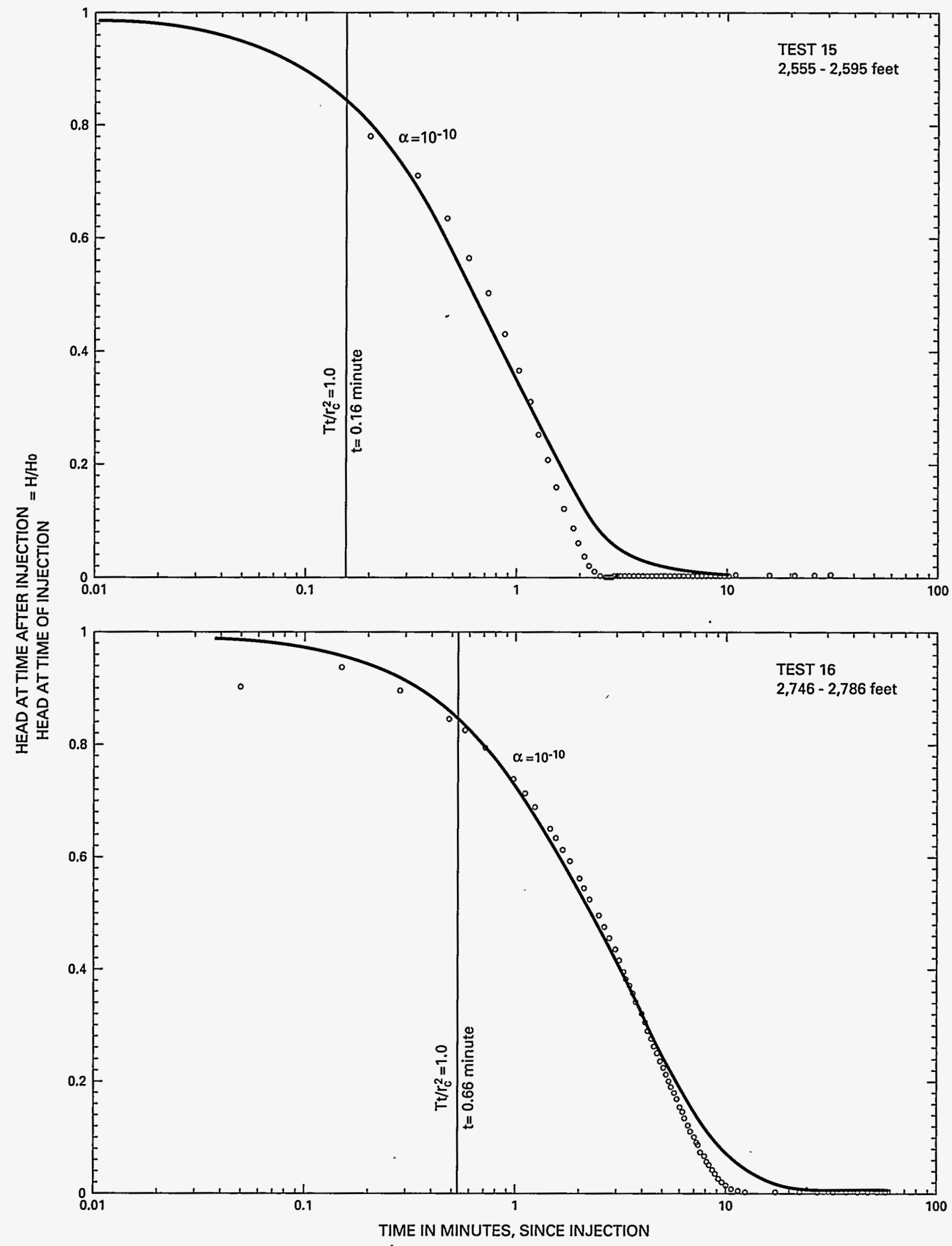

Figure 9E. Analyses of falling-head tests in borehole UE-25c \#1, October 1983, assuming an infinite, homogeneous, isotropic, confined aquifer (symbols on plots explained in text). 


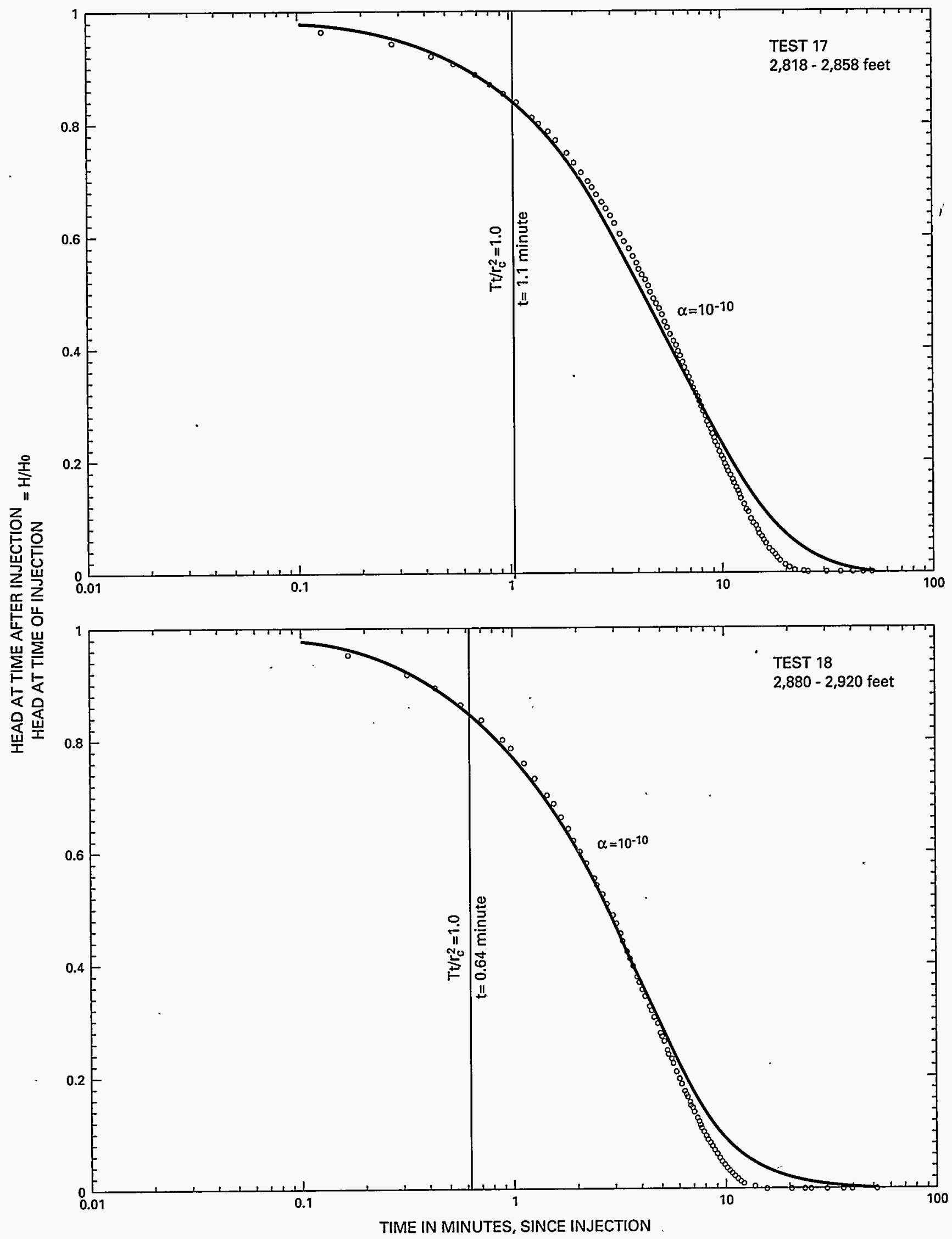

Figure 9F. Analyses of falling-head tests in borehole UE-25c \#1, October 1983, assuming an infinite, homogeneous, isotropic, confined aquifer (symbols on plots explained in text). 



Figure 9G. Analyses of falling-head tests in borehole UE-25c \#1, October 1983, assuming an infinite, homogeneous, isotropic,
confined aquifer (symbols on plots explained in text). 


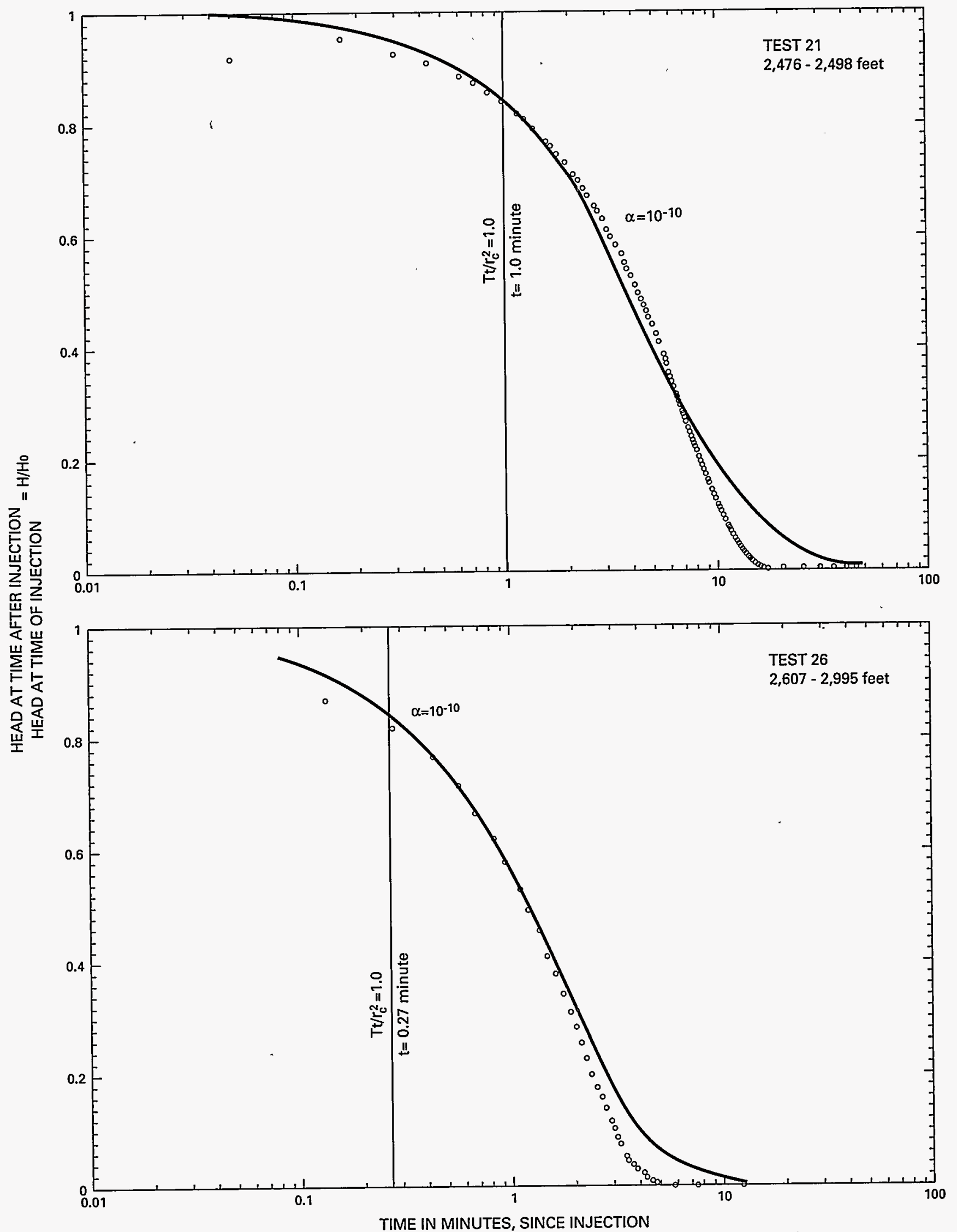

Figure $9 H$. Analyses of falling-head tests in borehole UE-25c \#1, October 1983, assuming an infinite, homogeneous, isotropic, confined aquifer (symbols on plots explained in text).

Results and Interpretation of Preliminary Aquifer Tests in Boreholes UE-25c \#1, UE-25c \#2, and UE-25c \#3, Yucca Mountain, Nye County, Nevada 


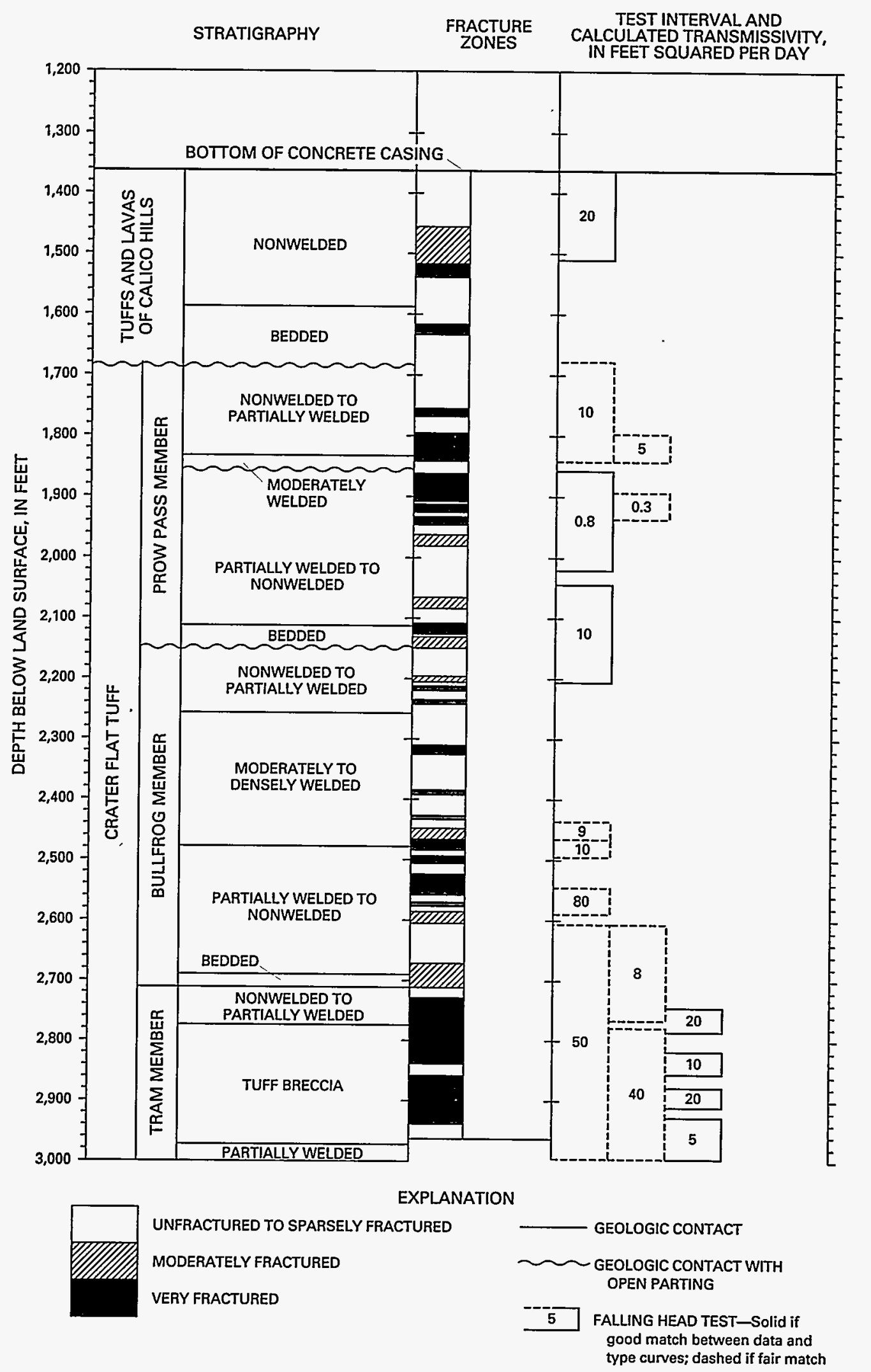

Figure 10. Falling-head tests and transmissivity values obtained in relation to geology, borehole UE-25c \#1. 
Table 8. Results of pressure-injection tests conducted in borehole UE-25c \#1, October 6-12, 1983

[n.a., test not analyzed because of insufficient or unreliable data; n.s., no solution determined]

\begin{tabular}{|c|c|c|c|c|c|c|c|c|}
\hline $\begin{array}{c}\text { Test } \\
\text { number }\end{array}$ & $\begin{array}{l}\text { Test interval } \\
\text { depth } \\
\text { (feet) }\end{array}$ & Geologlc descrjption of test interval & $\begin{array}{l}\text { Rocorded } \\
\text { head } \\
\text { (pounds } \\
\text { per } \\
\text { square } \\
\text { inch) }\end{array}$ & $\begin{array}{l}\text { Antecedent } \\
\text { head } \\
\text { (pounds } \\
\text { per square } \\
\text { (nch) }\end{array}$ & $\begin{array}{l}\text { Residual } \\
\text { head } \\
\text { (pounds } \\
\text { per } \\
\text { square } \\
\text { inch) }\end{array}$ & $\begin{array}{c}\text { Duration } \\
\text { of } \\
\text { pressure } \\
\text { decay } \\
\text { (minutes) }\end{array}$ & $\begin{array}{c}\text { Trang- } \\
\text { mlssittvily } \\
\text { (feot } \\
\text { squared } \\
\text { per day) }\end{array}$ & $\begin{array}{l}\text { Hydraullc } \\
\text { conductlvity } \\
\text { (feet per } \\
\text { day) }\end{array}$ \\
\hline 5 & $2,270-2,430$ & $\begin{array}{l}\text { Unfractured, moderately to densely, welded tuff with thin } \\
\text { fractured intervals }\end{array}$ & n.a. & n.a. & n.a. & $\overline{\text { n.a. }}$ & n.a. & n.a. \\
\hline 8 & $1,525-1,565$ & Unfractured and very fractured, nonwelded tuff & 388.65 & 142.28 & 246.37 & 96 & n.s. & n.s. \\
\hline 9 & $1,634-1,674$ & Sparsely fractured, bedded tuff & 552.97 & 397.35 & 155.62 & 98 & 1 & 0.03 \\
\hline 11 & $1,870-1,910$ & Very fractured, nonwelded to partially welded tuff & n.a. & n.a. & n.a. & n.a. & n.a. & n.a. \\
\hline 13 & $1,940-1,980$ & $\begin{array}{l}\text { Unfractured to very fractured, nonwelded to partially } \\
\text { welded tuff }\end{array}$ & 567.31 & 315.09 & 252.22 & 78 & 6 & 0.2 \\
\hline 14 & $2,215-2,255$ & $\begin{array}{l}\text { Unfractured and very fractured, nonwelded to partially } \\
\text { welded tuff }\end{array}$ & 550.17 & 389.36 & 160.81 & 34 & 10 & 0.3 \\
\hline 22 & $2,498-2,520$ & $\begin{array}{l}\text { Unfractured and very fractured, nonwelded to partially } \\
\text { welded tuff }\end{array}$ & n.a. & n.a. & n.a. & n.a. & n.a. & n.a. \\
\hline 23 & $2,575-2,597$ & $\begin{array}{l}\text { Unfractured to very fractured, nonwelded to partially } \\
\text { welded tuff }\end{array}$ & 922.52 & 544.63 & 377.89 & 96 & 10 & 0.4 \\
\hline 25 & $2,508-2,530$ & $\begin{array}{l}\text { Sparsely to moderately fractured, nonwelded to partially } \\
\text { welded tuff }\end{array}$ & n.a. & n.a. & n.a. & n.a. & n.a. & n.a. \\
\hline
\end{tabular}


modified by Neuzil (1982). Assumptions of this method are the same as those discussed previously for the falling-head tests. In this method, pressure decay at the end of the first shut-in period is extrapolated to establish unambiguously an antecedent pressure trend before the second shut-in period. Antecedent pressure is subtracted from pressures recorded during the second shut-in period, and the residual pressure decay is analyzed. If $\alpha$, as defined previously, is less than or equal to 0.1 , then transmissivity is calculated from equation 2 (Cooper and others, 1967). If $\alpha$ is between 0.1 and 10 , the product of transmissivity and storativity, TS, can be calculated from the following equations (Bredehoeft and Papadopulos, 1980; Neuzil, 1982):

$$
\alpha \beta=\frac{\pi r_{s}^{2} T S t}{\left(V_{w} C_{n b s} \rho_{w} g\right)^{2}}
$$

and

$$
C_{o b s}=\frac{\Delta V / V_{w}}{\Delta P}
$$

where,

$$
\begin{aligned}
\rho_{w} & =\text { density of water }\left(\mathrm{M} / \mathrm{L}^{3}\right) ; \\
g & =\text { gravitational acceleration }\left(\mathrm{L}^{2} \mathrm{~T}^{2}\right) ; \\
V_{w} & =\text { volume of water in pressurized interval }\left(\mathrm{L}^{3}\right) ; \\
\Delta V & =\text { injected volume of water }\left(\mathrm{L}^{3}\right) ; \text { and } \\
\Delta P= & \text { pressure pulse resulting from injected } \\
& \text { volume of water }\left(\mathrm{M} / \mathrm{L}^{2}\right) .
\end{aligned}
$$

At values of $\alpha$ greater than 0.1 , transmissivity can be calculated if the storativity can be determined independently.

The five pressure-injection tests that could be analyzed, all had in common a downward bulge in the middle-time data on a semi-log plot of head recovery as a function of time. This bulge made it impossible to match the data curve for test 8 to any type curve. For test 9 , a questionable match was made between the data and type curves. For tests 13,14 , and 23, the bulge was small enough that a fairly reliable match could be made between data curves and type curves (fig. 11).

The reason for the downward bulge in the data curves is unknown. It could be an artifact of the coarse recording interval of the Sperry-Sun gauge (two minutes), or it could indicate a problem in the mechanical set-up. A transmissivity value obtained from test 13 that is substantially larger than would be expected from a falling-head test conducted in an interval that includes the one in which test 13 was run seems to indicate that pressures applied could have opened fracture apertures in some pressure-injection tests. This would violate one of the fundamental assumptions of the test method, that fracture apertures are independent of pressure, and would invalidate the results of any tests thus affected. The transmissivity value obtained from test 13 was considered invalid because of possible "hydrofracturing".

Only tests 9, 14, and 23 were considered to have produced reasonable values of transmissivity and hydraulic conductivity. Transmissivity values in tests 9,14 , and 23 ranged from 1 to $10 \mathrm{ft}^{2} / \mathrm{d}$, and hydraulic conductivity values in these tests ranged from 0.03 to $0.4 \mathrm{ft} / \mathrm{d}$ (table 8).

The results of the falling head and pressure injection tests were combined to extrapolate the hydraulic conductivity distribution within a small radius of borehole UE-25c \#1. As shown in figure 12, hydraulic conductivity in the vicinity of borehole UE-25c \#1 was estimated to range from 0.005 to $0.6 \mathrm{ft} / \mathrm{d}$. The average hydraulic conductivity in the horizontal direction was estimated to be $0.2 \mathrm{ft} / \mathrm{d}$, whereas the average hydraulic conductivity in the vertical direction was estimated to be $0.02 \mathrm{ft} / \mathrm{d}$.

On the basis of the hydraulic conductivity distribution, the transmissivity distribution within a small radius of borehole UE-25c \#1 was estimated for aquifers and the entire thickness of rocks in the open part of the borehole (fig. 12). The Calico Hills aquifer was estimated to have a transmissivity of $22 \mathrm{ft}^{2} / \mathrm{d}$; the Prow Pass-upper Bullfrog aquifer was estimáted to have a transmissivity of $34 \mathrm{ft}^{2} / \mathrm{d}$; the Bullfrog aquifer was estimated to have a transmissivity of $152 \mathrm{ft}^{2} / \mathrm{d}$; and the Tram aquifer was estimated to have a transmissivity of $44 \mathrm{ft}^{2}$. The composite transmissivity of rocks below casing and concrete in borehole UE-25c \#1 was estimated to be $261 \mathrm{ft}^{2}$. As discussed later in the report, the composite transmissivity value obtained from fluidinjection tests in borehole UE-25c \#1 virtually is identical to the composite transmissivity value obtained by pumping borehole UE-25c \#3.

\section{CONSTANT-FLUX TESTS}

Five pumping tests and a constant-flux injection test were conducted in the c-holes between September 1983 and December 1984. With the completion of each additional borehole at the c-hole complex, the monitoring network for these constant-flux tests was expanded, the conceptual model of ground-water flow at the c-hole complex was refined, and test components, such as the rate of flux, the duration of fluid injection or withdrawal, and the length of time that recovery was monitored, were changed in accordance with information learned from previous tests. The design of these tests, problems encountered, possible 


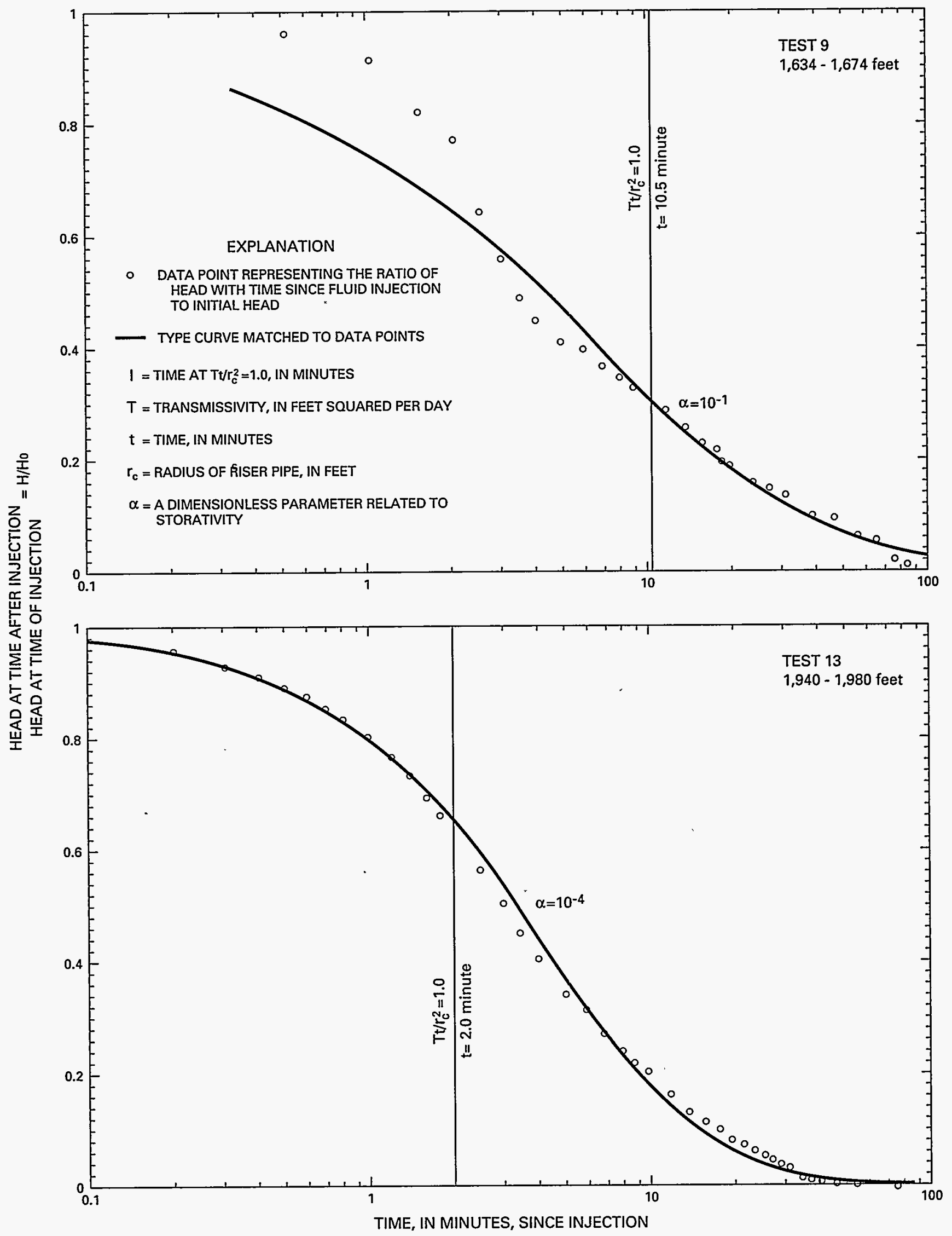

Figure 11A. Analyses of pressure-injection tests conducted in borehole UE-25c \#1, October 1983, assuming an infinite, homogeneous, isotropic, confined aquifer (symbols on plots are explained in the text).

36 Results and Interpretation of Preliminary Aquifer Tests in Boreholes UE-25c \#1, UE-25c \#2, and UE-25c \#3, Yucca Mountain, Nye County, Nevada 


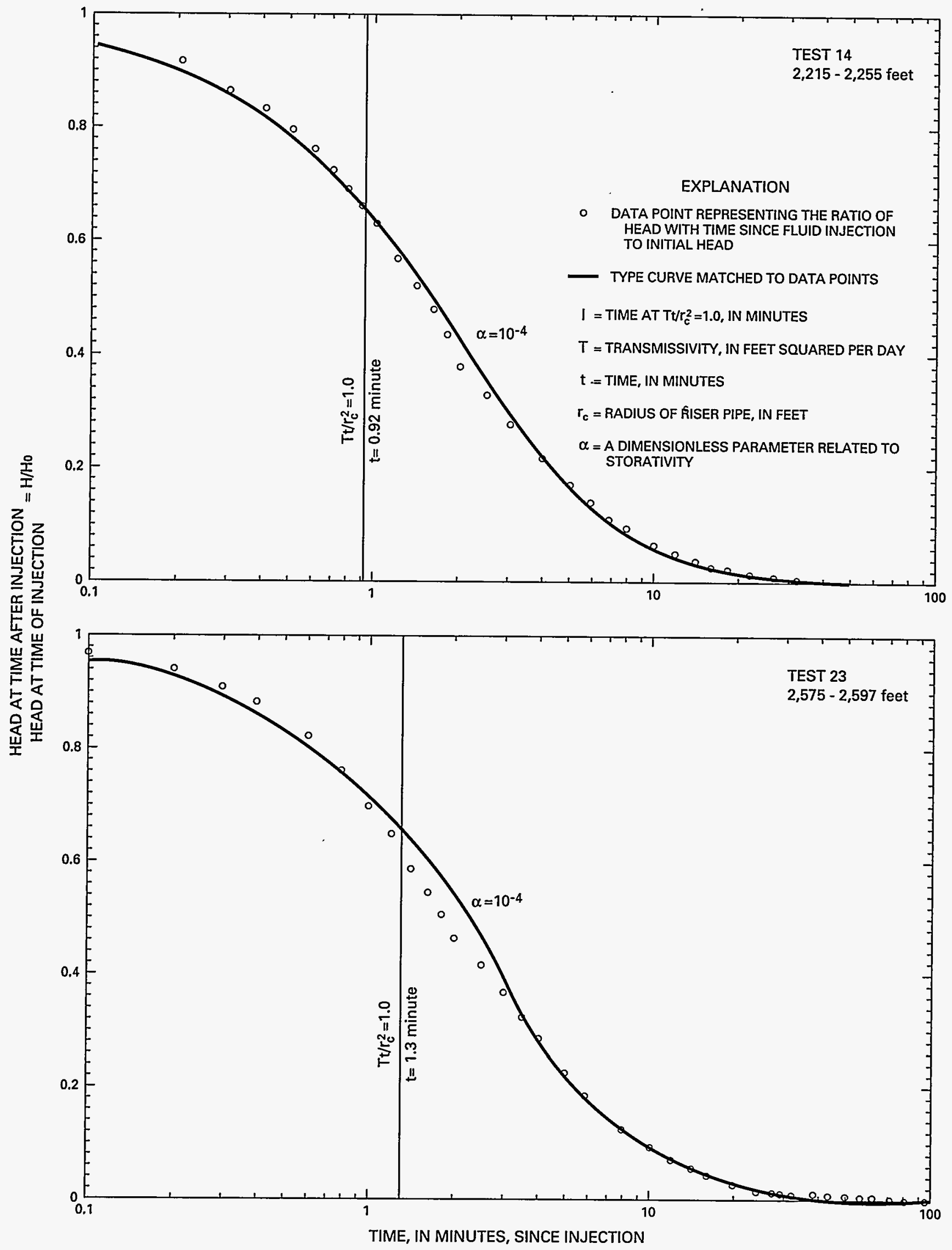

Figure 11B. Analyses of pressure-injection tests conducted in borehole UE-25c \#1, October 1983, assuming an infinite, homogeneous, isotropic, confined aquifer (symbols on plots are explained in the text). 


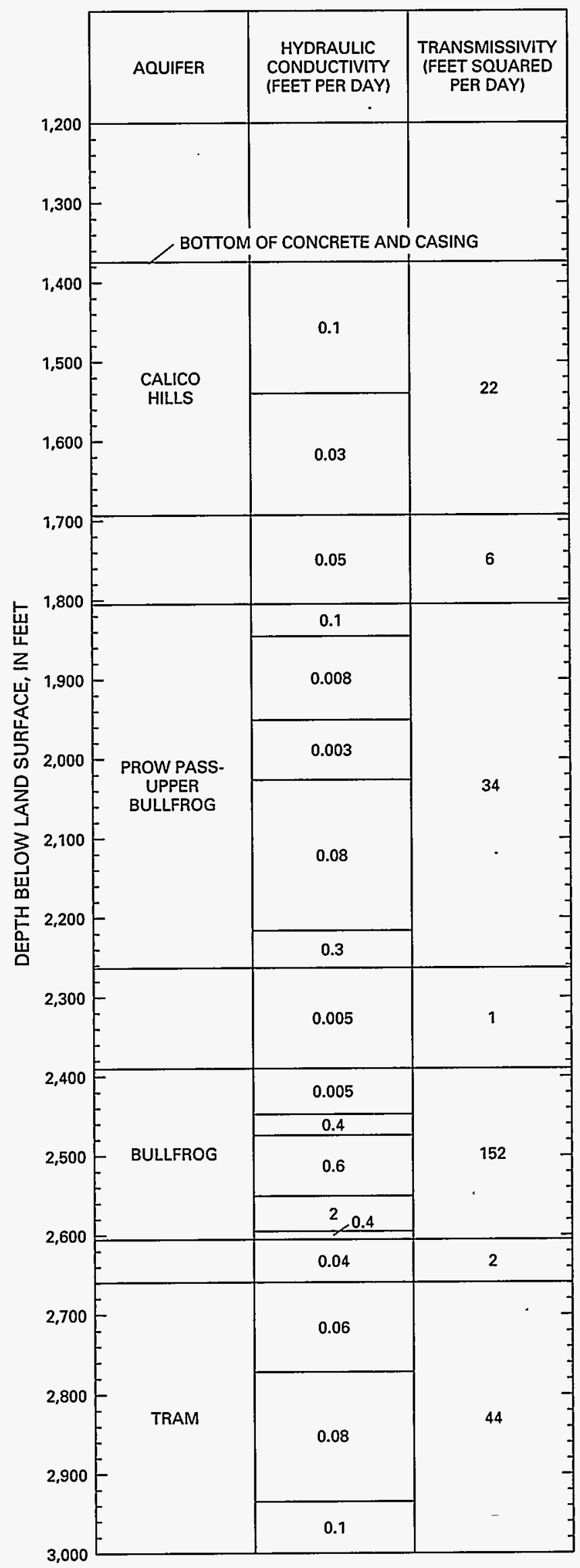

Figure 12. Transmissivity and hydraulic conductivity distributions within a small radius of borehole UE-25c \#1, estimated from falling-head and pressure-injection tests.

38 Results and Interpretation of Preliminary Aquifer Tests in Boreholes UE-25c \#1, UE-25c \#2, and UE-25c \#3, Yucca Mountain, Nye County, Nevada 
ground-water flow models that explain hydraulic head changes with time during the tests, and ranges in hydrologic properties calculated on the basis of analytical solutions for different possible ground-water flow models are presented in this section of the report. For a general discussion of the principles of aquifer tests, the reader is referred to Lohman (1979) and Driscoll (1986).

\section{Analytical Methods}

Constant-flux tests conducted at Yucca Mountain, including tests conducted in the c-holes discussed later in this section, rarely produce a transient response characteristic of an infinite, homogeneous, isotropic, confined aquifer-the exponential-integral curve of Theis (1935). As indicated by Robison and Craig (1991), plots of the log of water-level change as a function of the log of time typically result in a two-humped curve or a curve that flattens out. Additionally, the early-time data are characterized by borehole storage effects (Gringarten, 1982), and the late-time data commonly contain oscillations that Galloway and Rojstaczer (1988) attributed to Earth tides and changes in atmospheric pressure. In this report, constant-flux tests in the c-holes are interpreted with respect to four analytical ground-water models: (1) An infinite, homogeneous, isotropic, confined aquifer (Theis, 1935; Cooper and Jacob, 1946); (2) a leaky, homogeneous, isotropic, confined aquifer (Cooper, 1963); (3) a fissure-block (dual-porosity) aquifer (Streltsova-Adams, 1978); and (4) an infinite, homogeneous, anisotropic, unconfined aquifer (Neuman, 1975). The four analytical models used were selected because of their applicability to hydrogeologic characteristics of the c-hole complex discussed previously in this report.

Under the assumption of an infinite, homogeneous, isotropic, confined aquifer, water-level changes in observation wells are plotted as a function of time on $\log -\log$ paper and matched to the exponential-integral type curve of Theis (1935). The following equations are used to calculate hydrologic properties:

$$
\begin{gathered}
T=\frac{Q \times W(\mu)}{4 \pi s} \\
K_{r}=T / b
\end{gathered}
$$

and

$$
s=\frac{4 T t \mu}{r^{2}}
$$

where,

$$
\begin{aligned}
T= & \text { transmissivity }\left(\mathrm{L}^{2} / \mathrm{T}\right) ; \\
Q= & \text { rate of injection or withdrawal }\left(\mathrm{L}^{3} / \mathrm{T}\right) ; \\
W(\mu)= & \text { well function for an infinite, homogeneous, } \\
& \text { isotropic, confined aquifer (also called the } \\
& \text { exponential integral); } \\
\mu \quad= & \text { a dimensionless parameter defined by } \\
& \text { equation } 7 ; \\
K_{r}= & \text { horizontal hydraulic conductivity }(\mathrm{L} / \mathrm{T}) ; \\
b= & \text { thickness of transmissive intervals }(\mathrm{L}) ; \\
S= & \text { storativity (dimensionless); } \\
t= & \text { time since injection or withdrawal started or } \\
& \text { stopped (T) corresponding to } \mu ; \\
s \quad= & \text { water-level change (L) corresponding to } \\
& \text { W( }(\mu) ; \text { and } \\
r= & \text { distance from the pumped well to an } \\
& \text { observation well (L). }
\end{aligned}
$$

Under the same assumptions applicable to equations 5,6 , and 7 , the transmissivity of rocks in the pumped well can be analyzed by plotting residual drawdown as a function of the log of the ratio of time since injection or withdrawal started to time since injection or withdrawal stopped and solving the following equation (Theis, 1935):

$$
T=\frac{2.3 Q}{4 \pi \Delta s_{d}^{\prime}}
$$

where:

$\Delta s_{d}^{\prime}=$ the residual water-level change $(L)$ over one log cycle of the ratio of time since injection or withdrawal started to time since injection or withdrawal stopped; and all other variables are defined as in equation 5 .

Flattening of a plot of the log of drawdown in the pumped well or an observation well as a function of the log of time can be interpreted to indicate induced recharge from an aquifer boundary, as a hydraulic gradient develops between the boundary and the aquifer in response to pumping. This situation is analogous to leakage from a confining unit without storage during pumping. Analysis of drawdown in an aquifer with leakage from a confining unit without storage, according to Cooper (1963), is done by plotting the log of drawdown as a function of the log of the ratio of time since pumping started to the distance squared from the pumped well, matching the data curve to one of a family of type curves, and solving the following equations:

$$
T=\frac{Q \times L(\mu, v)}{4 \pi s}
$$




$$
S=\frac{4 T t / r^{2}}{1 / \mu}
$$

and

$$
v=\frac{r}{2} \times \sqrt{\frac{K^{\prime}}{T b^{\prime}}}
$$

where,

$$
\begin{aligned}
L(\mu, v)= & \text { well function of an infinite, homogeneous, } \\
& \text { isotropic, confined aquifer with leakage } \\
& \text { from a confining unit without storage; } \\
K^{\prime}= & \text { vertical hydraulic conductivity of the } \\
& \text { confining unit }(\mathrm{L} / \mathrm{T}) ; \\
b^{\prime}= & \text { thickness of the confining unit }(\mathrm{L}) ; \text { and } \\
\nu= & \text { a dimensionless parameter defined by } \\
& \text { equation } 11 ; \text { and all other variables are as } \\
& \text { defined previously. }
\end{aligned}
$$

The fissure-block model of ground-water flow can be analyzed either by straight-line techniques (Robison and Craig, 1991) or by curve-matching (Streltsova-Adams, 1978). If a pumping test proceeds long enough, a plot of drawdown in an observation well as a function of the log of time since pumping started is characterized by three segments. The first and third segments have twice the slope of the second segment, which is relatively flat. The third segment is analyzed using the following equations (Cooper and Jacob, 1946):

$$
T=\frac{2.3 Q}{4 \pi \Delta s_{d}}
$$

and

$$
S=\frac{2.25 T t_{0}}{r^{2}}
$$

where,

$\Delta s_{d}=$ drawdown (L) over one log cycle of time;

$t_{o}=$ time at point of zero drawdown (T); and

$r$ = distance from pumped well to observation well $(\mathrm{L})$; and all other variables are as defined previously.

If the test is terminated before the third segment is obtained, the second segment is analyzed with the denominator of equation 12 multiplied by 2 .

In the curve-matching technique of StreltsovaAdams (1978), the log of drawdown in an observation well as a function of the log of time is plotted and matched to a type curve with a shape determined by the ratio of total storativity to fracture storativity $(\eta)$, and by the ratio of the distance from the pumped well to the parameter $\mathrm{B}$, which is defined by the following equation:

$$
B=\sqrt{\frac{T H}{K_{b}}}
$$

where,

$T=$ transmissivity $\left(\mathrm{L}^{2} / \mathrm{T}\right)$

$H=$ the distance from the center of a block to a bounding fracture, equivalent to half the average distance between fractures $(\mathrm{L})$; and

$K_{b}=$ hydraulic conductivity of the blocks $(\mathrm{L} / \mathrm{T})$.

Matching the data curve to the type curve gives the transmissivity of the aquifer; matching the data curve to the early-time part of the type curve gives the fracture storativity; substituting the fracture storativity and $\eta$ into equation 17 below, gives the block storativity; rearranging equation 14 and solving for $K_{b}$ gives the block hydraulic conductivity; and dividing transmissivity by the thickness of transmissive intervals in the test interval gives the average fracture hydraulic conductivity. The analytical equations are:

$$
\begin{gathered}
T=\frac{Q \times W(\theta)}{4 \pi s} \\
S_{f}=\frac{4 T t}{r^{2}} \\
S_{b}=S_{f} \times(\eta-1) \\
K_{b}=\frac{T H}{B^{2}}
\end{gathered}
$$

and

$$
K_{f}=\frac{T}{b}
$$

where,

$$
\begin{aligned}
W(\theta)= & \text { well function of a fissure-block aquifer; } \\
s= & \text { drawdown in fractures }(\mathrm{L}) \text { corresponding to } \\
& \mathrm{W}(\theta) ; \\
S_{f}= & \text { fracture storativity (dimensionless); } \\
\theta= & \text { a dimensionless parameter defined by } \\
& \text { equation 16; } \\
t \quad= & \text { time since pumping started (T) } \\
& \text { corresponding to } \theta ; \\
K_{f}= & \text { hydraulic conductivity of the fractures } \\
& (\mathrm{L} / \mathrm{T}) ; \\
S_{b}= & \text { block storativity (dimensionless); and all } \\
& \text { other variables are as defined previously. }
\end{aligned}
$$


Because the type curves are very similar, estimating $\mathrm{r} / \mathrm{B}$ in advance of curve-matching is recommended. In analyzing the $c$-hole pumping tests, values of $\mathrm{r} / \mathrm{B}$ were estimated using the fracture data in the Supplementary Data section of this report, values of matrix permeability shown on pls. 1-3, and values of transmissivity estimated from plots of drawdown or recovery during aquifer tests as a function of the log of time. Hydraulic conductivity $(\mathrm{K})$, in feet per day, was estimated from matrix permeability ( $k$ ), in millidarcies by the following equation:

$$
K=\frac{k \rho_{w} g}{\mu}
$$

where,

$\mu=$ the dynamic viscosity of water

(in centipoise); and

$\rho_{w}$ and $g$ are defined as in equation 3.

The final analytical model considered in this report is an infinite, homogeneous, anisotropic, unconfined aquifer (Neuman, 1975). The method of analysis requires plotting the log of drawdown or recovery in either the pumped well or an observation well as a function of the log of the ratio of time since pumping started or stopped to distance squared from the pumped well and matching the data curve to a type curve that consists of two relatively steep segments (Type $A$ and Type B curves) separated by a relatively flat transitional segment. The shape of the transitional curve is related to the anisotropy of the aquifer. Matching the data curve to either the early-time or late-time part of a type curve gives the transmissivity; matching the data curve to the early-time part of a type curve gives the storativity; and matching the data curve to the late-time part of a type curve gives the specific yield. Hydrologic properties are calculated using the following equations:

$$
\begin{gathered}
T=\frac{Q \times W\left(\mu_{A}, \mu_{B}, \beta\right)}{4 \pi s} \\
S=\frac{4 T t \mu_{A}}{r^{2}} \\
S_{y}=\frac{4 T t \mu_{B}}{r^{2}}
\end{gathered}
$$

and

$$
\beta=\frac{K_{z} r^{2}}{K_{r} b^{2}}
$$

where,

$$
\begin{aligned}
W\left(\mu_{A}, \mu_{B} \beta\right)=\text { well function for an unconfined } & \text { aquifer; } \\
s \quad= & \text { drawdown }(\mathrm{L}) \text { corresponding to } \\
& W\left(\mu_{\mathrm{A}}, \mu_{\mathrm{B}}, B\right) ; \\
\mu_{A}= & \text { a dimensionless parameter defined by } \\
& \text { equation } 22 ; \\
\mu_{B}= & \text { a dimensionless parameter defined by } \\
& \text { equation } 23 ; \\
t \quad= & \text { time since pumping started (T) } \\
& \text { corresponding to } \mu_{\mathrm{A}} \text { or } \mu_{\mathrm{B}} ; \\
\beta \quad= & \text { a dimensionless parameter defined by } \\
& \text { equation } 24 ; \\
S_{y}= & \text { specific yield (dimensionless); } \\
K_{\mathrm{z}}= & \text { vertical hydraulic conductivity (L/T); and } \\
& \text { all other variables are as defined previously. }
\end{aligned}
$$

To calculate hydrologic properties using the unconfined aquifer solution of Neuman (1975) first requires estimating the parameter $B$, which, in turn, requires estimates of vertical hydraulic conductivity $\left(\mathrm{K}_{\mathrm{z}}\right)$ and horizontal hydraulic conductivity $\left(\mathrm{K}_{\mathrm{r}}\right)$. Initial estimates of $K_{\mathrm{Z}}$ and $\mathrm{K}_{\mathrm{r}}$ were obtained from values of interval hydraulic conductivity determined from the previously discussed fluid-injection tests in borehole UE-25c \#1. The values of hydraulic conductivity determined from the fluid injection tests were inserted into equations given by Freeze and Cherry (1979) for determining average values of vertical and horizontal hydraulic conductivity in rocks with layered hydraulic conductivity. The equations used were:

$$
K_{z}=\frac{b}{\sum_{i=1}^{n} \frac{b_{i}}{\bar{K}_{i}}}
$$

and

$$
K_{r}=\sum_{i=1}^{n} \frac{K_{i} b_{i}}{b}
$$

where:

$K_{i}=$ hydraulic conductivity of a layer $(\mathrm{L} / \mathrm{T})$;

$b_{i}=$ thickness of a layer (L);

$b=$ total thickness of layers (L); and

$n=$ the number of layers.

In observation wells with packers emplaced to isolate selected intervals, the proportion of discharge contributed from above, between, and below the packers in an observation well had to be estimated to solve equations $5,9,15$, and 21 . The results of heat-pulse flowmeter surveys conducted in the c-holes; that are 
shown on plates $1-3$, were used to proportionalize discharge.

Pumping tests with residual head changes from preceding tests or significant recovery (more than about 10 percent of drawdown) caused by a pump failure during the test were analyzed applying the principle that the effects of superimposed cycles of fluid injection or withdrawal and recovery are additive. The following equations were used during analysis of a pumping test to separate total recorded drawdown into component parts:

$$
\begin{gathered}
s=s_{T}-s_{A} \\
r_{1}=s_{1}-s_{T} \\
s_{2}=s_{T}-s_{1}+r_{1}
\end{gathered}
$$

and

$$
r_{2}=s_{1}-r_{1}+s_{2}-s_{T}
$$

where

$s_{T}=$ total recorded drawdown (L);

$s \quad=$ drawdown caused by continuous pumping (L);

$s_{A}=$ residual drawdown from a previous aquifer test $(\mathrm{L})$;

$s_{1}=$ drawdown caused by continuous pumping or pumping prior to a pump failure (L);

$s_{2}=$ drawdown caused by pumping following a period during which a pump failure occurred (L);

$r_{1}=$ water-level recovery after shutting off a pump following continuous pumping or during a pump failure $(\mathrm{L})$; and

$r_{2}=$ water-level recovery following pumping interrupted by a pump failure (L).

Values of $s_{A}, s_{1}, s_{2}$, and $r_{1}$ were estimated beyond the time each was recorded by extrapolation of the slope of the recorded data on a plot of water-level change as a function of the log of time.

Where depths to water were recorded in piezometers open to the surface, and a recording barometer was operated during an aquifer test, recorded drawdown data were corrected for atmospheric pressure changes based on values of barometric efficiency obtained by Galloway and Rojstaczer (1988) from simultaneous records of water levels in the c-holes and borehole UE-25p \#1 and atmospheric pressure during 1986. Above packers emplaced between depths of about 2,400 to $2,600 \mathrm{ft}$, and in open boreholes, a barometric efficiency of 0.8 was used for the c-holes. Between packers emplaced between 2,400 and $2,600 \mathrm{ft}$ and below the packers, a barometric efficiency of 0.85 was used for the c-holes. In borehole UE-25p \#1 below a packer emplaced $4,255 \mathrm{ft}$ below the land surface to isolate the Miocene tuffaceous rocks from the Paleozoic carbonate rocks, a barometric efficiency of 0.75 was used. Oscillations in recorded drawdown caused by Earth tides were handled by a visual best-fit match of type curves to curves of drawdown or recovery through the oscillations.

\section{Pumping Tests in Borehole UE-25c \#1}

Two unsuccessful pumping tests were conducted in borehole UE-25c \#1 in September and October 1983 , immediately after completion of the borehole. During each test, borehole UE-25p \#1, 2,028 ft southeast of the pumped well, was monitored to determine whether the Miocene tuffaceous rocks, and the Paleozoic carbonate rocks are connected hydraulically in the vicinity of the c-holes. Atmospheric pressure at borehole UE-25c \#1 was recorded on a Validyne digital barometer.

Borehole UE-25c \#1 was open during the pumping tests in the tuffs and lavas of Calico Hills and the Crater Flat Tuff, from the bottom of concrete at a depth of $1,371 \mathrm{ft}$, to the bottom of the borehole at a depth of 2,995 ft (USGS logbook for borehole UE-25c \#1, unpublished). A Centrilift submersible pump was emplaced in the borehole from 1,399 to $1,477 \mathrm{ft}$ below land surface, with the pump intake at $1,416 \mathrm{ft}$ below land surface (Fenix and Scisson, Inc., written commun., 1983). A 5.5-in.-outside-diameter riser pipe extended from the pump to the wellhead, where it was coupled to a 6-in.-diameter, steel discharge pipe with an in-line flowmeter and end-line orifice plate and manometer (USGS logbook for borehole UE-25c \#1, unpublished). Depth to water in the borehole was monitored with a Bell and Howell pressure transducer with a recording range of 0 to $50 \mathrm{lb} / \mathrm{in}^{2}$, that was connected at the surface to a Fluke data logger (USGS logbook for borehole UE-25c \#1, unpublished). The calibrated depth of the transducer was $1,423 \mathrm{ft}$ below land surface (110 $\mathrm{ft}$ below the static water level in the borehole).

Borehole UE-25p \#1 is part of a water-level monitoring network at Yucca Mountain and is permanently configured to record hydraulic head in the Paleozoic rocks near the c-hole complex (Robison and others, 1988). Borehole UE-25p \#1 is cased and grouted through the tuffaceous rocks to a depth of $4,256 \mathrm{ft}$ below land surface $(175 \mathrm{ft}$ below the contact between the Miocene and Paleozoic rocks in the borehole). Hydraulic head in the Paleozoic rocks is recorded with a pressure transducer suspended inside a

42 Results and Interpretation of Preliminary Aquifer Tests in Boreholes UE-25c \#1, UE-25c \#2, and UE-25c \#3, Yucca Mountaln, Nye County, Nevada 
1.9-in.-outside-diameter plastic piezometer tube. During the pumping tests in borehole UE-25c \#1, a Bell and Howell pressure transducer with a recording range of 0 to $10 \mathrm{lb} / \mathrm{in}^{2}{ }^{2}$, that was connected at the surface to a Fluke data logger, was used in the borehole (USGS logbook for borehole UE-25c \#1, unpublished). The calibrated depth of the transducer was $1,198 \mathrm{ft}$ below land surface, and $7.5 \mathrm{ft}$ below the static water level in the piezometer tube (USGS records, unpublished).

Following several periods of pumping lasting from 10 minutes to 11.5 hours, during which the discharge rate was varied between 242 and $500 \mathrm{gal} / \mathrm{min}$, equipment to be used in the pumping tests was evaluated, borehole UE-25c \#1 was flushed of drilling debris, and a pumping test was started in borehole UE-25c \#1 on September 27, 1983. The pump was off for 22 hours prior to the test, and the water level was static when the test began. At an average discharge rate of $234 \mathrm{gal} / \mathrm{min}$, a volume of $1,192,969 \mathrm{gal}$ of water was withdrawn from the pumped well during the test (USGS records, unpublished). Pumping lowered the water level in borehole UE-25c \#1 about $100 \mathrm{ft}$ to the pump intake in about 12 minutes, where it remained until pumping ceased on September 30, 1983, 3.5 days after the test began (USGS records, unpublished). After the pump was shut off, the water level in . borehole UE-25c \#1 rose abruptly, and residual drawdown was negligible 10.3 minutes after pumping ended (USGS records, unpublished).

A second pumping test in borehole UE-25c \#1 took place 11 hours after the first pumping test on October 1, 1983 (USGS logbook for borehole UE-25c \#1, unpublished). During the first 12 minutes of the test, pumping at an average rate of $216 \mathrm{gal} / \mathrm{min}$ again lowered the water level in the pumped well to the pump intake (USGS records, unpublished). After 11.8 hours, the pump failed for about 10 minutes, and the water level in the pumped well recovered 83 percent (USGS records, unpublished). After the pump was restarted, the water level again decreased rapidly to the pump intake. Pumping continued at an average rate of $213 \mathrm{gal} / \mathrm{min}$ for another 19.6 hours until on October 2, the pump was shut off, and the water level in the pumped well again recovered rapidly (USGS records, unpublished).

The pumping tests conducted in borehole UE-25c \#1 generally were a failure. Drawdown and recovery in borehole UE-25c \#1 could not be analyzed quantitatively, because the depth to water during most of each pumping test was controlled by the depth of the pump intake and not the hydrologic properties of the rocks being tested. Clearly, a smaller capacity pump should have been used for these tests. Both pumping tests in borehole UE-25c \#1 were too short to produce any discernible effect on the water level in borehole UE-25p \#1. Thus, neither test could be used to determine whether the Miocene and Paleozoic rocks are connected hydraulically in the vicinity of the c-holes.

\section{Pumping Test in Borehole UE-25c \#2}

A pumping test was conducted in borehole UE-25c \#2 in March 1984, several days after completion of the borehole. During the test, water levels in the pumped well, in borehole UE-25c \#1, $251 \mathrm{ft}$ northnortheast of the pumped well, and in borehole UE-25p \#1, 1,971 ft east-southeast of the pumped well, were monitored. Atmospheric pressure during the test was recorded on a Validyne digital barometer located at borehole USW H-4, 7,466 ft northwest of borehole UE-25c \#2.

\section{Procedures and Problems}

Borehole UE-25c \#2 was open during the pumping test in the tuffs and lavas of Calico Hills and the Crater Flat Tuff, from the bottom of concrete, at a depth of $1,365 \mathrm{ft}$, to the bottom of the borehole, at a depth of 2,999 ft (USGS logbook for borehole UE-25c \#2, unpublished). A Centrilift submersible pump was emplaced in the borehole from 1,420 to $1,485 \mathrm{ft}$ below land surface, with the pump intake at $1,447 \mathrm{ft}$ below land surface (Fenix and Scisson, Inc., written commun., 1984). A 5.5-in.-outside-diameter riser pipe extended from the pump to the wellhead, where it was coupled to a 6-in.-diameter, steel discharge pipe with an in-line flowmeter and end-line orifice plate and manometer (USGS logbook for borehole UE-25c \#2, unpublished). Depth to water in the borehole was monitored with a Bell and Howell pressure transducer with a recording range of 0 to $25 \mathrm{lb} /$ in. $^{2}$, that was suspended inside a 2.4-in.-diameter access tube and connected at the surface to a Fluke data logger (USGS logbook for borehole UE-25c \#2, unpublished). The calibrated depth of the transducer was $1,369 \mathrm{ft}$ below the top of the access tube, $50 \mathrm{ft}$ below the static water level inside the tube (USGS records, unpublished).

Borehole UE-25c \#1 was monitored above and between straddle packers suspended on a 2.9-in.outside-diameter plastic tube between depths of 2,510 and 2,610 ft (Fenix and Scisson, Inc., written commun., 1984). From the bottom of concrete to the top of the packers, borehole UE-25c \#1 was open from the Calico Hills aquifer to the top of the Bullfrog aquifer (fig. 7). Between the packers, at depths of 2,520 to $2,600 \mathrm{ft}$, borehole UE-25c \#1 was open in the lower part of the Bullfrog aquifer. Depth to water above the packers was 
monitored with a Bell and Howell pressure transducer with a recording range of 0 to $10 \mathrm{lb} / \mathrm{in}^{2}$, that was connected at the surface to a Fluke data logger (USGS logbook for borehole UE-25c \#2, unpublished). The calibrated depth of the transducer to monitor the interval above the packers was $1,355 \mathrm{ft}$ below the top of casing, $20 \mathrm{ft}$ below the static water level in the borehole. Depth to water between the packers was monitored with a Bell and Howell pressure transducer with a recording range of 0 to $25 \mathrm{lb} / \mathrm{in}^{2}$, that was suspended inside the tube on which the packers were hung and connected at the surface to a Fluke data logger (USGS logbook for borehole UE-25c \#2, unpublished). The calibrated depth of the transducer to monitor the interval between the packers was $1,369 \mathrm{ft}$ below the top of tubing, $50 \mathrm{ft}$ below the static water level inside the tube.

In borehole UE-25p \#1, depth to water inside the piezometer tube that was open to the Paleozoic rocks was monitored with a Bell and Howell vented pressure transducer with a recording range of 0 to $15 \mathrm{lb} / \mathrm{in}$. ${ }^{2}$, that was connected at the surface to a Fluke data logger (USGS logbook for borehole UE-25c\#2, unpublished). The calibrated depth of the transducer was $1,205 \mathrm{ft}$ below the top of the piezometer tube, $15 \mathrm{ft}$ below the static water level inside the tube.

Five days prior to the pumping test in borehole UE-25c \#2, the borehole was cleaned of debris by repeated cycles of pumping and recovery over a period of five hours. Discharges during this procedure ranged from 321 to $335 \mathrm{gal} / \mathrm{min}$ (USGS logbook for borehole UE-25c \#2, unpublished). On March 7, 1984, from 0350 to 0423 , several attempts were made to begin a pumping test in borehole UE-25c \#2, but the longest the pump remained operative during this time was 23 minutes (USGS logbook for borehole UE-25c \#2, unpublished).

After complete water-level recovery (USGS records, unpublished) and several modifications to the equipment, a pumping test in borehole UE-25c \#2 was started successfully at 1742 on March 7, 1984 (USGS logbook for borehole UE-25c \#2, unpublished). Pumping continued until 1029 on March 14, 1984 (a period of about 6.7 days). Discharge during the pumping test stabilized within minutes of the pump being started at an average rate of $245 \mathrm{gal} / \mathrm{min}$, and a volume of $2,361,386$ gal of water was withdrawn during the test (USGS records, unpublished).

The pumping in borehole UE-25c \#2 caused the water level in the pumped well to decrease $8 \mathrm{ft}$ during the first minute of the test; shutting off the pump at the end of the test caused an equally abrupt increase in the water level (fig. 13). Complete recovery to the pre-test static water level in the pumped well occurred 1,165 minutes after pumping ceased. The pumping in borehole UE-25c \#2 drew down water levels in borehole UE-25c \#1 about $1.2 \mathrm{ft}$ above the packers and about $1.4 \mathrm{ft}$ between the packers (fig. 14). Considering the changes in atmospheric pressure during the test (fig. 15), water-level recovery in borehole UE-25c \#1, about 3.7 days after pumping ceased, was about 79 percent complete above the packers and 100 percent complete between the packers. The pumping in borehole UE-25c \#2 apparently caused the water level in borehole UE-25p \#1 to decrease after about 1,000 minutes (fig. 14), indicating that the Miocene tuffaceous rocks and Paleozoic carbonate rocks at the c-hole complex are connected hydraulically. Corrected for changes in atmospheric pressure, the water level in borehole UE-25p \#1 decreased $1.4 \mathrm{ft}$ while the pump was on and another $0.5 \mathrm{ft}$ in the 3.7 days that water levels were monitored after the pump was shut off.

\section{Test Analyses}

Despite oscillations, drawdown and recovery data from borehole UE-25c \#1 above the packers could be interpreted to conform to the analytical solution of either Streltsova-Adams (1978) for a fissure-block aquifer or Neuman (1975) for an unconfined, anisotropic aquifer. For both solutions, tuffaceous rocks above the packers were estimated from a heat-pulse flowmeter survey done in December 1991 to contribute 12.5 percent of the discharge from the entire thickness of rocks below casing and concrete in borehole UE-25c \#1.

Aquifer-test analysis using the fissure-block solution of Streltsova-Adams (1978) was guided by an estimate of $r / B=0.09$ that was obtained from the following: (1) Half the average distance between fractures in the interval above the packers $=2.6 \mathrm{ft}$; (2) log mean matrix hydraulic conductivity in the interval above the packers $=0.0009 \mathrm{ft} / \mathrm{d}$; and (3) a first approximation-estimate of transmissivity from the slope of the late-time data on a plot of drawdown as a function of the log of time during the pumping test $=3,200 \mathrm{ft}^{2} / \mathrm{d}$. The parameter $\mathrm{r} / \mathrm{B}$ was calculated as follows:

$$
\frac{r}{B}=\frac{r}{\sqrt{\frac{T \times H}{K_{b}}}}=\frac{270 f t}{\sqrt{\frac{3,200 f t^{2} / d \times 2.6 f t}{0.0009 f t / d}}}=0.09
$$

Fit to the type curve for $\eta=10$ and $r / B=0.3$, the drawdown data from borehole UE-25c \#1 above the packers (fig. 16) indicated the following values of transmissivity $(T)$, fracture storativity $\left(S_{f}\right)$, block storativity $\left(S_{b}\right)$, fracture hydraulic conductivity $\left(K_{f}\right)$, and block hydraulic conductivity $\left(K_{b}\right)$ : 


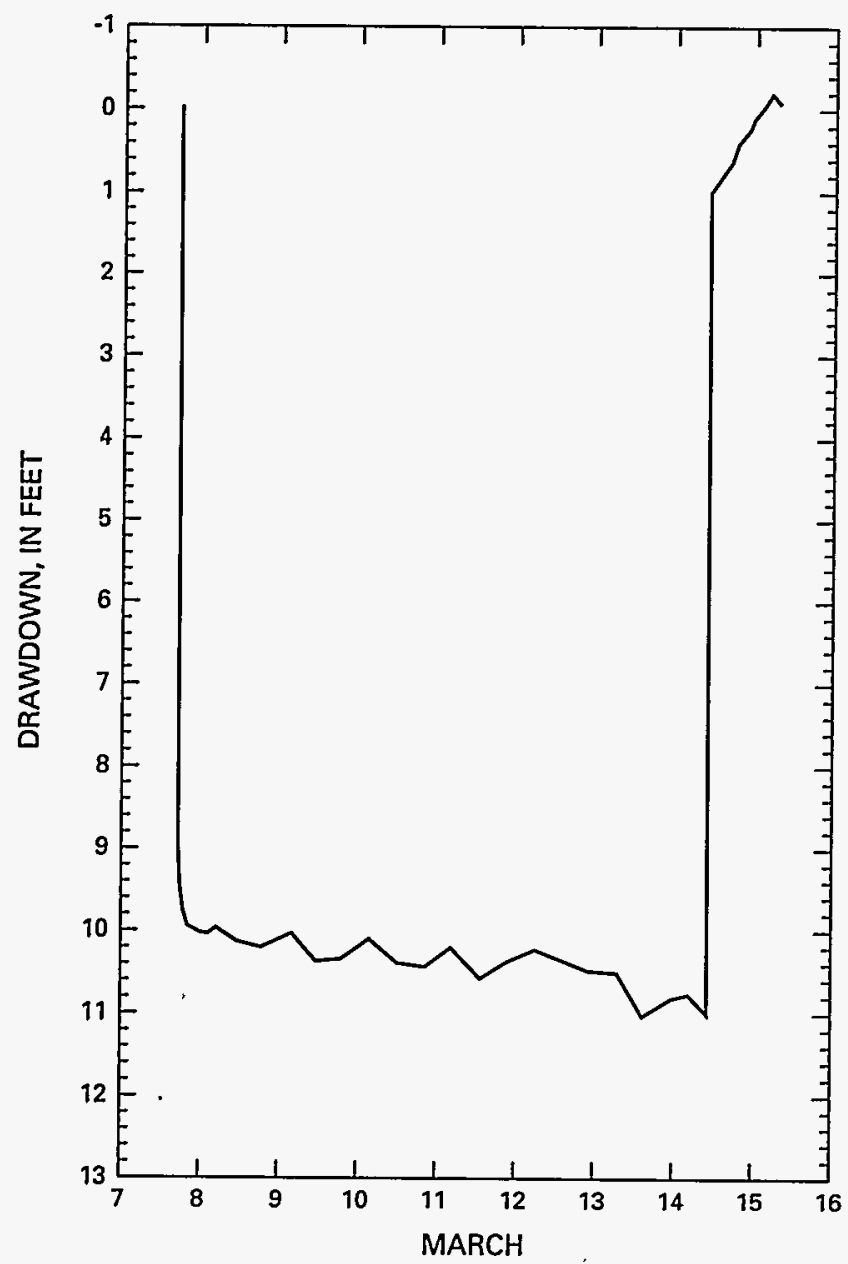

Figure 13. Drawdown as a function of time in borehole $\mathrm{UE}-25 \mathrm{c}$ \#2 during the pumping test in borehole UE-25c \#2, March 1984.

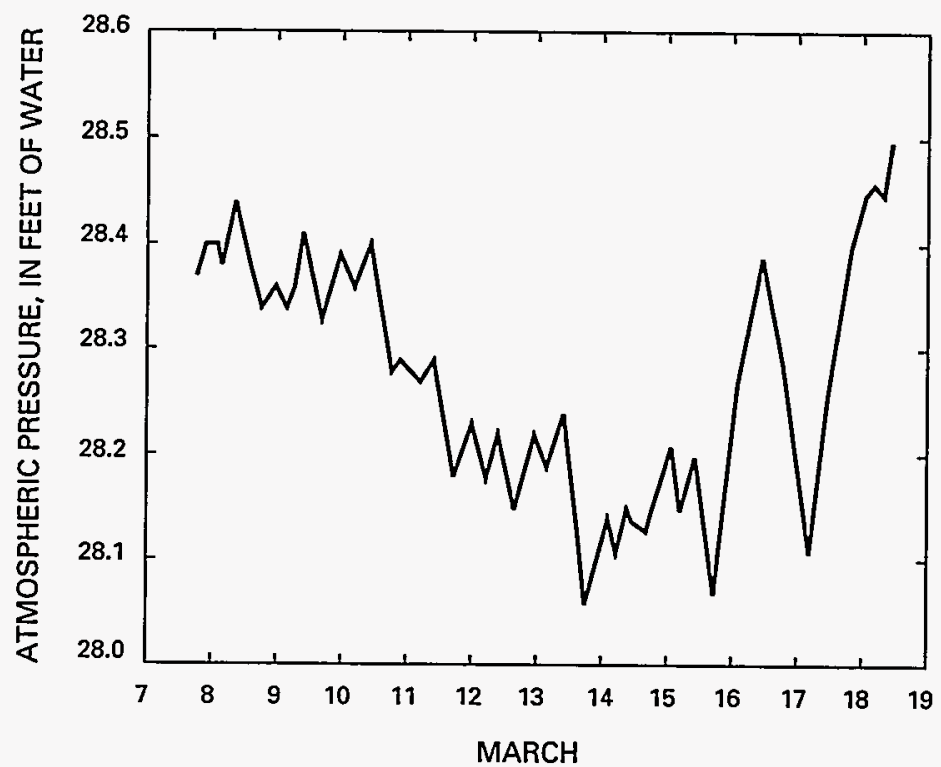

Figure 15. Atmospheric pressure at borehole USW H-4 during the pumping test in borehole UE-25c \#2, March 1984.

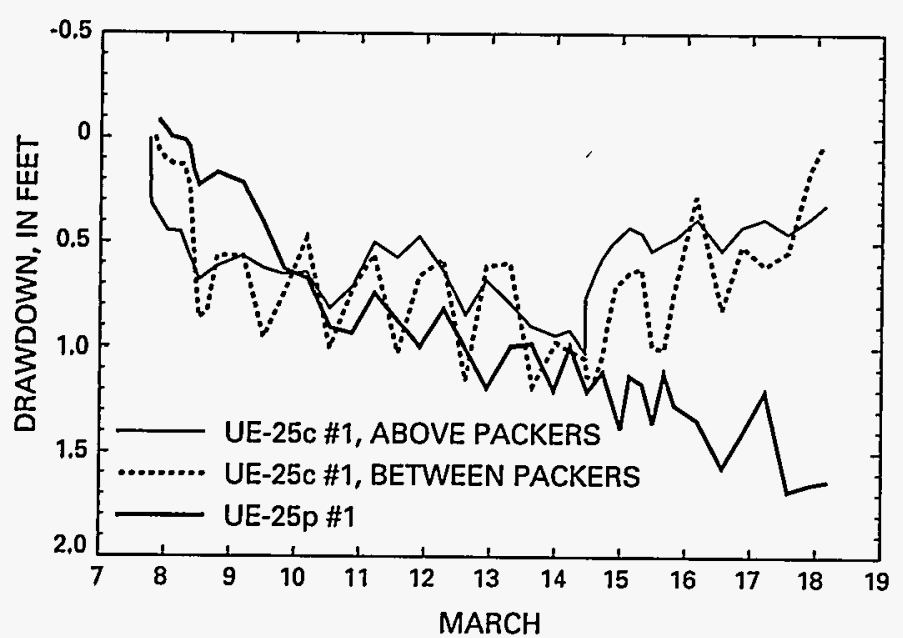

Figure 14. Drawdown as a function of time in boreholes UE-25c \#1 and UE-25p \#1 during the pumping test in borehole UE-25c \#2, March 1984. 


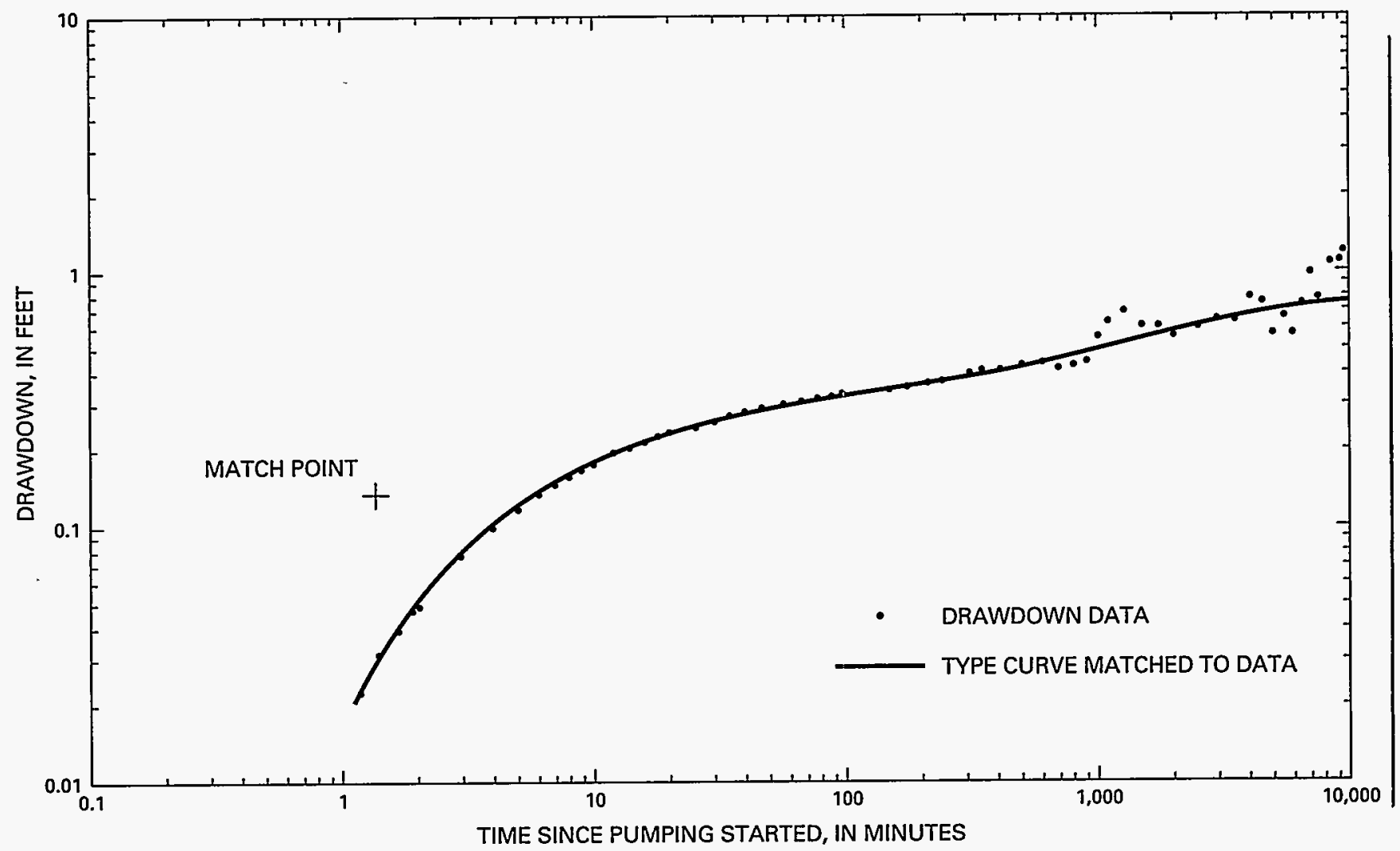

Figure 16. Analytical solution for drawdown data from borehole UE-25c \#1 above the packers assuming a fissure-block aquifer, pumping test in borehole UE-25c \#2, March 1984.

$$
\begin{gathered}
T=\frac{Q \times W(\theta)}{4 \pi s}=\frac{\left(0.125 \times 245 \mathrm{gal} / \mathrm{min} \times 192.5 f^{3} / d\right) \times 1}{(4 \pi \times 0.135 f t) \times 1 \mathrm{gal} / \mathrm{min}}=3,500 \mathrm{ft}^{2} / d \\
K_{f}=\frac{T}{b}=\frac{3,500 \mathrm{ft}^{2} / d}{524 \mathrm{ft}}=7 \mathrm{ft} / d \\
S_{f}=\frac{4 T t}{r^{2} \theta}=\frac{4 \times 3,500 \mathrm{ft}^{2} / d \times 1.35 \mathrm{~min}}{(270 f)^{2} \times 1 \times 1,440 \mathrm{~min} / \mathrm{d}}=0.0002 \\
S_{b}=S_{f} \times(\eta-1)=0.0002 \times(10-1)=0.002 \\
r / B=0.3 \\
B=\frac{r}{0.3}=\frac{270 f t}{0.3}=900 \mathrm{ft} \\
K_{b}=\frac{T \times H}{B^{2}}=\frac{3,500 f t^{2} / d \times 2.6 f t}{(900 f t)^{2}}=0.01 \mathrm{ft} / \mathrm{d}
\end{gathered}
$$

46 Results and Interpretation of Preliminary Aquifer Tests in Boreholes UE-25c \#1, UE-25c \#2, and UE-25c \#3, Yucca Mountain, Nye County, Nevada 
Aquifer-test analysis using the unconfined aquifer solution of Neuman (1975) was guided by an estimate of the parameter $B$, as follows:

$$
K_{z}=\frac{b}{\sum_{i=1}^{i} \frac{b_{i}}{\bar{K}_{i}}}
$$

$K_{z}=\frac{1,139}{(40 / 0.6+25 / 0.4+40 / 0.3+209 / 0.1+190 / 0.08+120 / 0.05+}$

$z=\frac{1,139}{(40 / 0.6+25 / 0.4+40 / 0.3+209 / 0.1+190 / 0.08+120 / 0.05+145 / 0.03+105 / 0.008+190 / 0.005+75 / 0.003)}$

$$
\begin{aligned}
& K_{z}=0.013 f t / d \\
& K_{r}=\sum_{i=1}^{i} \frac{K_{i} b}{b}
\end{aligned}
$$

$$
\begin{gathered}
K_{r}=\frac{(40 \times 0.6+25 \times 0.4+40 \times 0.3+209 \times 0.1+190 \times 0.08+120 \times 0.05+145 \times 0.03+105 \times 0.008+190 \times 0.005+75 \times 0.003)}{1,139} \\
K_{r}=0.083 \mathrm{ft} / \mathrm{d}
\end{gathered}
$$

Assuming $b$ is the thickness of transmissive intervals above the packers:

$$
\beta=\frac{K_{z} r^{2}}{K_{r} b^{2}}=\frac{0.013 f t / d \times(270 f t)^{2}}{0.083 f t / d \times(524 f t)^{2}}=0.04
$$

Fit to the type curve for $B=0.06$, the drawdown and recovery data from borehole UE-25c \#1 above the packers (fig. 17) indicated the following values of transmissivity $(T)$, storativity $(S)$, specific yield $\left(S_{y}\right)$, horizontal hydraulic conductivity, vertical hydraulic conductivity, and anisotropy $\left(K_{z} / K_{r}\right)$.

\section{Drawdown}

$$
\begin{aligned}
& T=\frac{Q}{4 \pi s} \times W\left(\mu_{A}, \mu_{B}, \beta\right) \\
& T=\frac{\left(0.125 \times 245 \mathrm{gal} / \mathrm{min} \times 192.5 f t^{3} / d\right) \times 1}{4 \pi \times 0.16 f \mathrm{ft} \times 1 \mathrm{gal} / \mathrm{min}} \\
& T=2,900 \mathrm{ft}^{2} / d \\
& S=\frac{4 T t \mu_{A}}{r^{2}} \\
& S=\frac{4 \times 2,900 \mathrm{ft}^{2} / d \times 1.5 \mathrm{~min} \times 1}{(270 f)^{2} \times 1,440 \mathrm{~min} / d} \\
& S=0.0002 \\
& S_{y}=\frac{4 T t \mu_{B}}{r^{2}} \\
& S_{y}=\frac{4 \times 2,900 f t^{2} / d \times 35 \mathrm{~min} \times 1}{(270 f t)^{2} \times 1,440 \mathrm{~min} / d} \\
& S_{y}=0.004
\end{aligned}
$$

$$
\begin{aligned}
T & =\frac{Q}{4 \pi s} \times W\left(\mu_{A^{\prime}}, \mu_{B}, \beta\right) \\
T & =\frac{\left(0.125 \times 245 \mathrm{gal} / \mathrm{min} \times 192.5 f t^{3} / d\right) \times 1}{4 \pi \times 0.16 f t \times 1 \mathrm{gal} / \mathrm{min}} \\
T & =2,900 \mathrm{ft}^{2} / d \\
S & =\frac{4 T t \mu_{A}}{r^{2}} \\
S & =\frac{4 \times 2,900 f t^{2} / d \times 2 \mathrm{~min} \times 1}{(270 f t)^{2} \times 1,440 \mathrm{~min} / d} \\
S & =0.0002 \\
S_{y} & =\frac{4 T t \mu_{B}}{r^{2}} \\
S & =\frac{4 \times 2,900 f t^{2} / d \times 25 \mathrm{~min} \times 1}{(270 f t)^{2} \times 1,440 \mathrm{~min} / d} \\
S_{y} & =0.003
\end{aligned}
$$


Assuming $\mathrm{b}$ is the thickness of transmissive intervals:

$$
\begin{gathered}
K_{r}=T / b=\frac{2,900 f t^{2} / d}{524 f t}=6 f t / d \\
K_{z}=\frac{K_{r} b^{2} \beta}{r^{2}}=\frac{6 f t / d \times(524 f t)^{2} \times 0.06}{(270 f t)^{2}}=1 f t / d \\
K_{z} / K_{r}=1 / 6=0.2
\end{gathered}
$$

\section{First Pumping Test in Borehole UE-25c \#3}

A pumping test was conducted in borehole UE-25c \#3 from May to June 1984, primarily to determine the composite transmissivity of the tuffaceous rocks penetrated by borehole UE-25c \#3 and the transmissivity of the tuffs and lavas of Calico Hills at the c-hole complex. During the test, water levels were monitored in the pumped well, in borehole UE-25c \#2 ( $100 \mathrm{ft}$ southeast of the pumped well) in borehole $\mathrm{UE}-25 \mathrm{c} \# 1$ (224 ft northeast of the pumped well) and in borehole UE-25p \#1 (2,067 ft southeast of the pumped well). No barometric record during this pumping test was found in USGS files.

\section{Procedures and Problems}

The pumped well, borehole UE-25c \#3, was open in the tuffs and lavas of Calico Hills and the Crater Flat Tuff, from the bottom of concrete, at a depth of $1,368 \mathrm{ft}$, to the bottom of the borehole, at a depth of $3,000 \mathrm{ft}$ (Fenix and Scisson, Inc., written commun., 1984). A Centrilift submersible pump was emplaced in the borehole from 1,439 to $1,484 \mathrm{ft}$ below land surface, with the pump intake at $1,454 \mathrm{ft}$ below land surface (Fenix and Scisson, written commun., 1984). A 5.5-in.-outside-diameter riser pipe extended from the pump to the wellhead, where it was coupled to a 6-in.-diameter, steel discharge pipe with an in-line flowmeter and an end-line orifice plate and manometer (USGS logbook for borehole UE-25c \#3, unpublished). Depth to water in the pumped well was monitored with a Bell and Howell pressure transducer with a recording range of 0 to $50 \mathrm{lb} / \mathrm{in}^{2}{ }^{2}$, that was suspended inside a

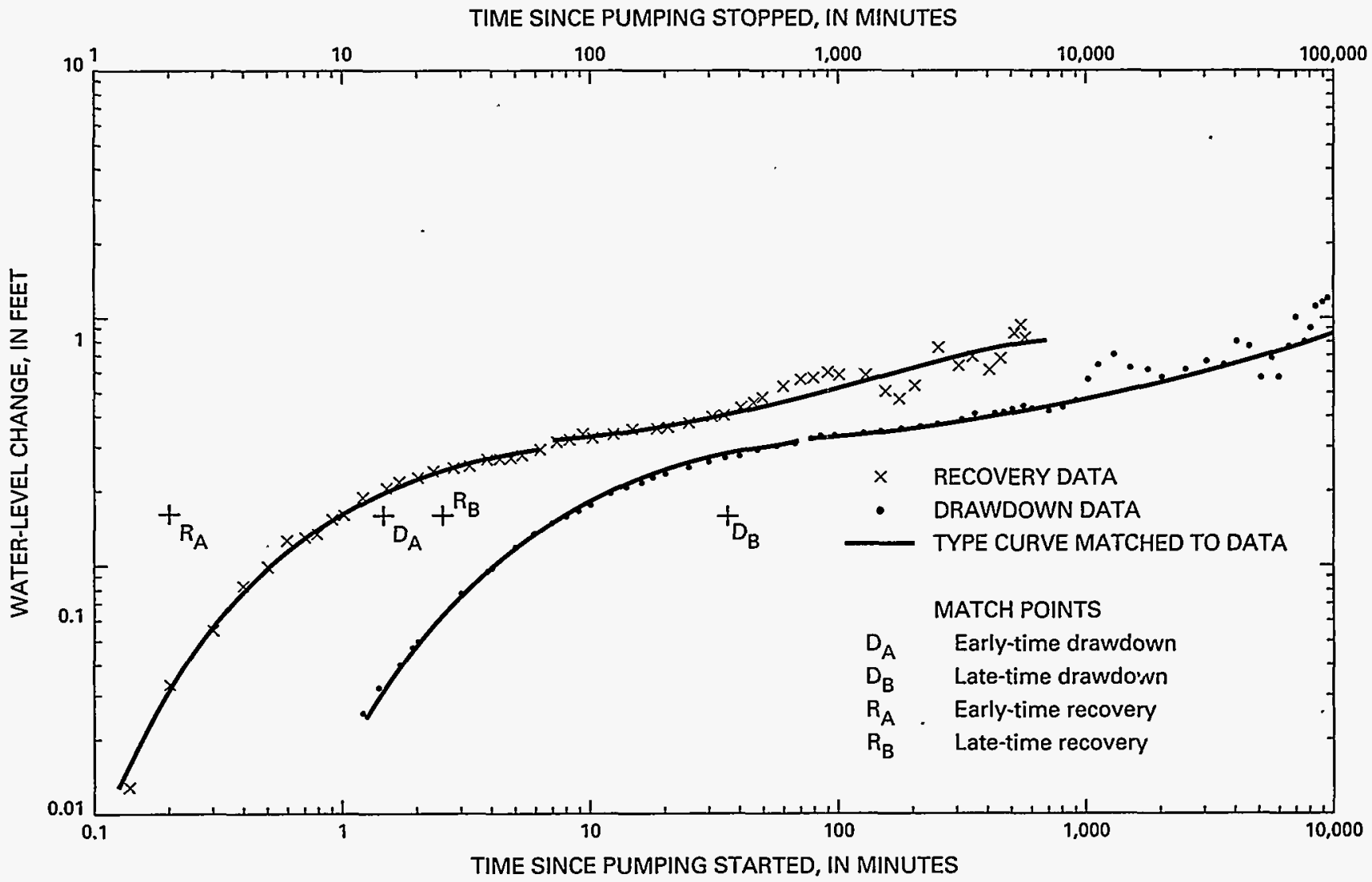

Figure 17. Analytical solutions for drawdown and recovery data from borehole UE-25c \#1 above the packers assuming an infinite, homogeneous, anisotropic, unconfined aquifer, pumping test in borehole UE-25c \#1, March 1984.

48 Results and Interpretation of Preliminary Aqulfer Tests in Boreholes UE-25c \#1, UE-25c \#2, and UE-25c \#3, Yucca Mountain, Nye County, Nevada 
2.4-in.-diameter access tube and connected at the surface to a Fluke data logger (USGS logbook for borehole UE-25c \#3, unpublished). The calibrated depth of the transducer was $1,420 \mathrm{ft}$ below the top of the access tube, $100 \mathrm{ft}$ below the static water level inside the tube (USGS records, unpublished).

Borehole UE-25c \#2 was open in the tuffs and lavas of Calico Hills and the Crater Flat Tuff, from the bottom of concrete, at a depth of $1,365 \mathrm{ft}$, to the bottom of the borehole, at a depth of about 2,990 ft (USGS logbook for borehole UE-25c \#3, unpublished). Depth to water in the borehole was monitored with a Bell and Howell pressure transducer with a recording range of 0 to $25 \mathrm{lb} /$ in. $^{2}$, that was connected at the surface to a Fluke data logger. The calibrated depth of the transducer was $1,340 \mathrm{ft}$ below the top of the casing, $20 \mathrm{ft}$ below the static water level in the borehole (USGS records, unpublished).

Borehole UE-25c \#1 was monitored above, between, and below straddle packers (Fenix and Scisson, Inc., written commun., 1984). Above the packers, between depths of 1,371 and 1,595 ft, the borehole was open in the nonwelded, upper part of the tuffs and lavas of Calico Hills. Between the packers, from 1,605 to $1,680 \mathrm{ft}$, the borehole was open in the bedded, lower part of the tuffs and lavas of Calico Hills. Below the packers, between depths of 1,690 and $2,962 \mathrm{ft}$, the borehole was open in the Crater Flat Tuff. Hydraulic heads above, between, and below the packers were monitored with GRC temperaturecompensated pressure transducers with a recording range of 0 to 2,500 lb/in. ${ }^{2}$ (USGS records, unpublished). The packers and instrumentation were suspended on 2.9-in.-outside-diameter plastic tubing. The transducers were connected at the surface by waterproofed cable to a Hewlett-Packard (HP-85) data logger (USGS logbook for borehole UE-25c \#3, unpublished). After installation of equipment and prior to testing, borehole UE-25c \#1 was shut in to minimize barometric effects on water-level changes (USGS logbook for borehole UE-25c \#3, unpublished).

Borehole UE-25p \#1, as in previous tests, was monitored to record hydraulic head in the Paleozoic rocks in the vicinity of the c-holes. Depth to water inside a piezometer tube was monitored with a pressure transducer with a recording range of 0 to $15 \mathrm{lb} / \mathrm{in}^{2}{ }^{2}$, that was connected at the surface to a Fluke data logger. The calibrated depth of the transducer was $1,190 \mathrm{ft}$ below the top of the piezometer tube, $9 \mathrm{ft}$ below the static water level inside the tube (USGS records, unpublished).

Without prior development, pumping began in borehole UE-25c \#3 at 2257 on May 4, 1984, and continued until 1002 on May 14, 1984, a period of about
9.5 days (USGS logbook for borehole UE-25c \#3, unpublished). The test was interrupted by a pump failure on May 9, 1984 (6,520 min into the test), that lasted 163 minutes. Prior to the pump failure, the discharge averaged $420 \mathrm{gal} / \mathrm{min}$, but it took 25 hours for the discharge to stabilize. After the pump was restarted, the discharge quickly stabilized at an average rate of $414 \mathrm{gal} / \mathrm{min}$. For the entire pumping period, the average discharge rate was $418 \mathrm{gal} / \mathrm{min}$, and a volume of $5,623,928$ gallons of water was withdrawn (USGS logbook for borehole UE-25c \#3, unpublished).

In addition to the pump failure, the first pumping test in borehole UE-25c \#3 was hampered by several other mechanical problems. Diurnal fluctuations of 1 to $4 \mathrm{mv}$ in the system power supply, coupled with Earth tides, caused daily fluctuations of water levels in some of the boreholes. On the average, the water level in borehole UE-25c \#2 was $0.35 \mathrm{ft}$ higher at 0600 than at 1700 during and after the period in which the pump was operating; the water level in borehole UE-25c \#3 fluctuated $1.5 \mathrm{ft}$ between 0600 and 1700 after the pump was shut off. The transducer in borehole UE-25c \#1 below the packers was inoperative during the entire pumping test. Finally, intermittent failure of data logging equipment resulted in gaps of as much as seven days in recorded drawdown and recovery in each of the c-holes.

As in the pumping test in borehole UE-25c \#2, turning the pump on and off during the pumping test in borehole UE-25c \#3 caused rapid, large changes in the water level in the pumped well (fig. 18A). Ten minutes after pumping began, the water level in borehole $\mathrm{UE}-25 \mathrm{c} \# 3$ had decreased $61 \mathrm{ft}$; during the pumping failure, the water level in this borehole recovered to within three percent of the static level; when the pump was shut off on May 14, 1984, the water level in the pumped well rose $67 \mathrm{ft}$ in ten minutes. Maximum drawdown in the pumped well during this test was about $72 \mathrm{ft}$ (USGS records, unpublished).

The drawdown in boreholes UE-25c \#2 and UE-25c \#1 caused by pumping borehole UE-25c \#3 was much slower and smaller than in the pumped well. The maximum drawdown in borehole UE-25c \#2 was about $1.7 \mathrm{ft}$ (fig. 18B), the maximum drawdown in borehole UE-25c \#1 above the packers was about $18 \mathrm{ft}$ (fig. 19A), and the maximum drawdown in borehole UE-25c \#1 between the packers was about $11 \mathrm{ft}$ (fig. 19B). The pumping did not cause a change in the water level in borehole UE-25 p\#1 that could be distinguished from water-level fluctuations related to Earth tides, atmospheric pressure changes, variations in the discharge rate, and mechanical problems (USGS records, unpublished). The pump failure caused an 86 percent water-level recovery in borehole 
UE-25c \#2, about one percent recovery in borehole UE-25c \#1 between the packers, and no discernible recovery in borehole UE-25c \#1 above the packers (figs. 18 and 19). On June 12, 28.9 days after the pump was shut off, recovery in borehole UE-25c \#2 was
100 percent complete, recovery in borehole UE-25c \#1 between the packers was 20 percent complete, and no recovery had occurred in borehole UE-25c $\# 1$ above the packers.

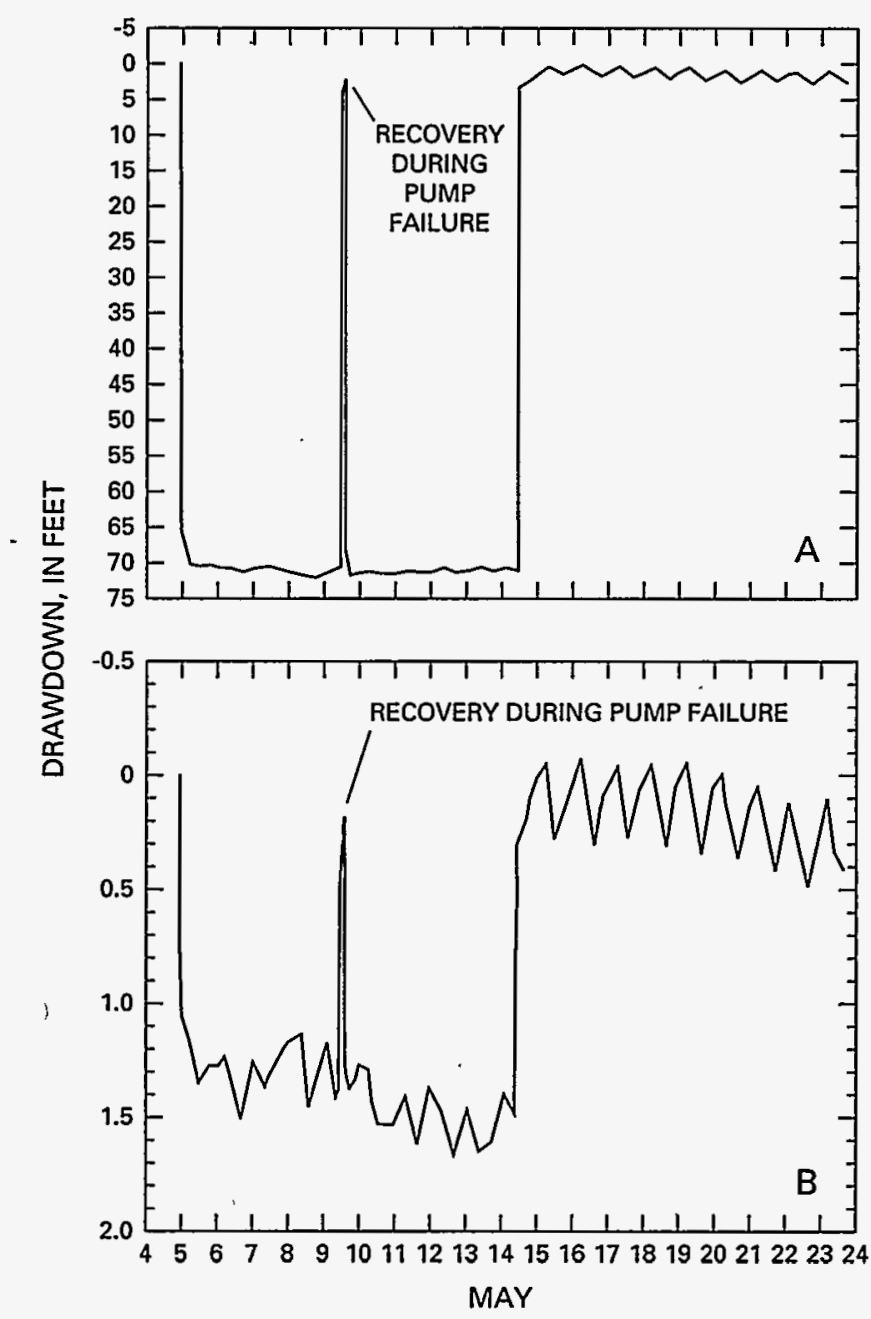

Figure 18. Drawdown as a function of time during the pumping test in borehole UE-25c \#3, May to June 1984: (A); Borehole UE-25c \#3; (B), Borehole UE-25c \#2 (data from unpublished USGS records). 


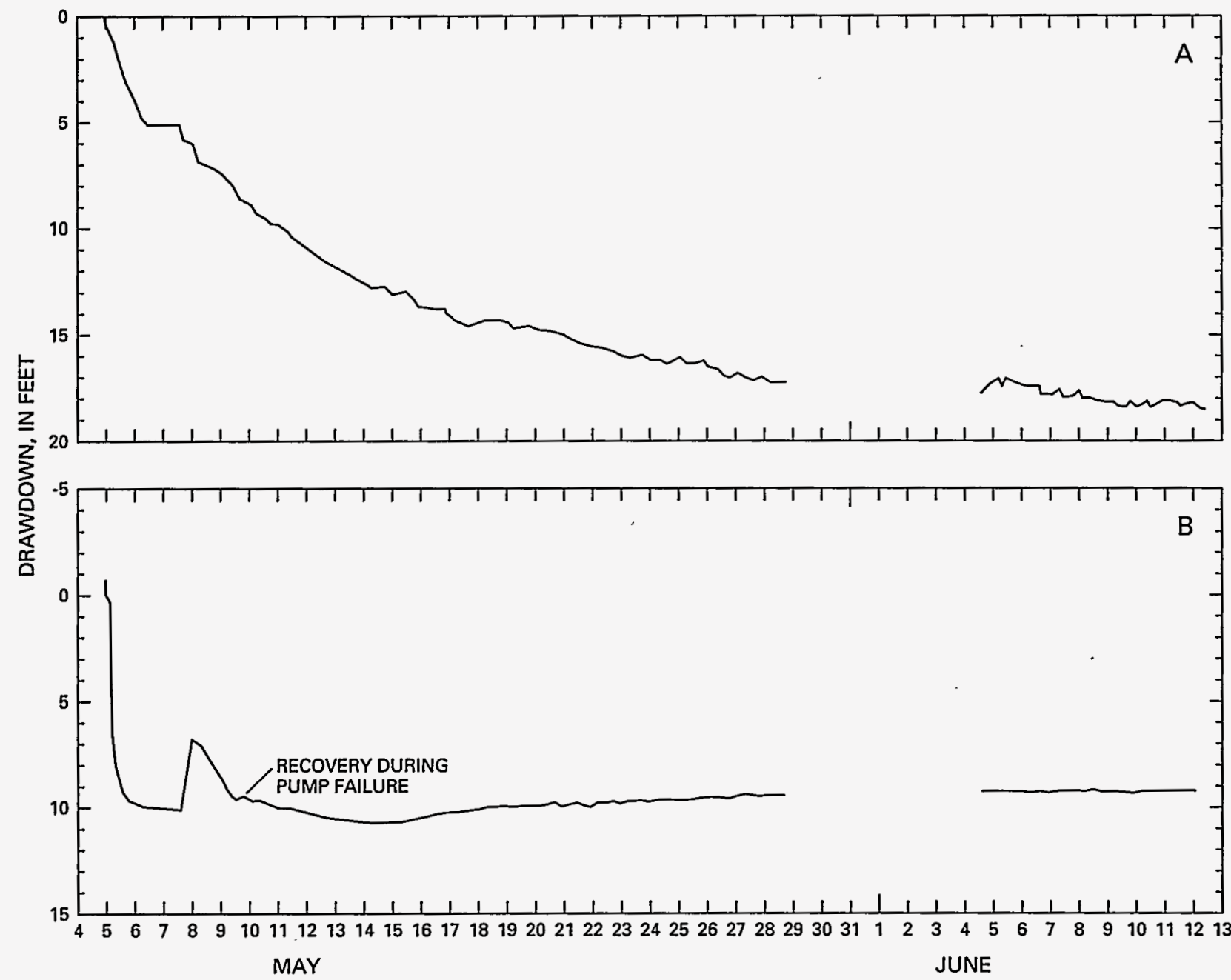

Figure 19. Drawdown as a function of time in borehole UE-25c \#1 during the pumping test in borehole UE-25c \#3, May to June 1984: (A), above the packers; (B), between the packers (data from unpublished USGS records).

\section{Test Analyses}

The first pumping test in borehole UE-25c \#3 provided analyzable data sets from boreholes UE-25c \#3, UE-25c \#2, UE-25c \#1 above the packers, and UE-25c \#1 between the packers. Because of the variable discharge rate during the first 25 hours of the test, more weight was given in analyses to data obtained later in the pumping phase and during the recovery phase of the test. Based on atmospheric corrections of less than $0.25 \mathrm{ft}$ that were applied during the pumping test in borehole UE-25c \#2, it is believed that failure to obtain a barometric record during the first pumping test in borehole UE-25c \#3 potentially would have affected only analyses of data from monitored intervals where drawdown or recovery did not exceed two feet. Thus, only analyses of data from borehole UE-25c \#2 and recovery data from borehole UE-25c\#1 between the packers might have been improved by correcting for atmospheric pressure change.

Analyses of the data from the pumped well, borehole UE-25c \#3, by two methods indicated nearly identical values of transmissivity and hydraulic conductivity. Under the assumption of an infinite, homogeneous, isotropic, confined aquifer (Theis, 1935), a plot of residual drawdown as a function of the $\log$ of the ratio of time since the pump was restarted to time since pumping stopped (fig. 20) indicated the following: 


$$
T=\frac{2.3 Q}{4 \pi \Delta s_{d}^{\prime}}=\frac{2.3 \times 414 \mathrm{gal} / \mathrm{min} \times 192.5 \mathrm{ft}^{3} / \mathrm{d}}{4 \pi \times(60.0-5.6 \mathrm{ft}) \times 1 \mathrm{gal} / \mathrm{min}}=270 \mathrm{ft}^{2} / d
$$

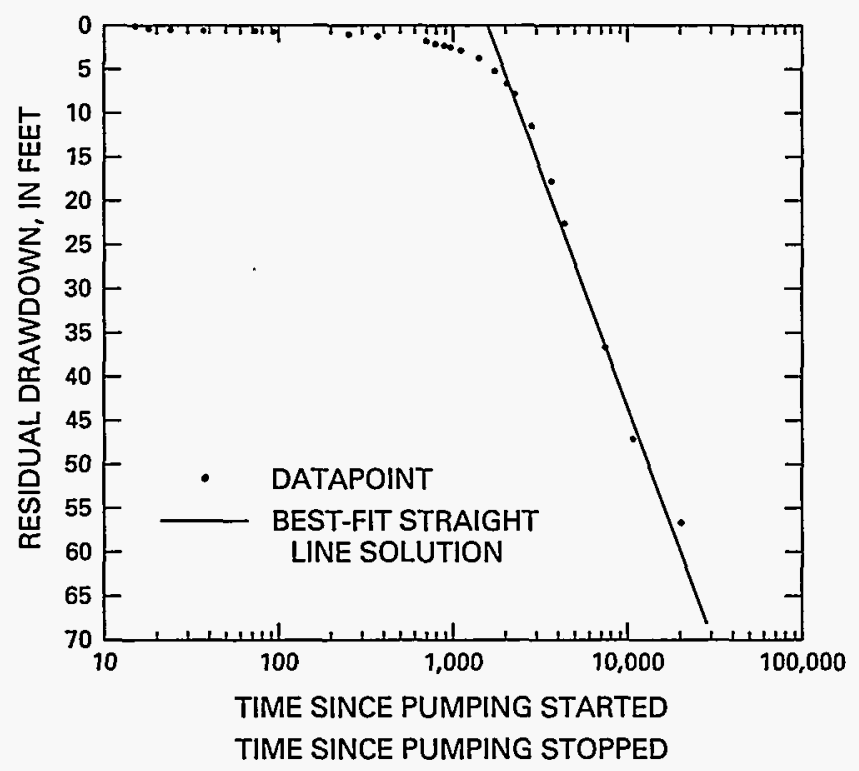

Figure 20. Analytical solution for residual drawdown data from borehole UE-25c \#3 assuming an infinite, homogeneous, isotropic, confined aquifer, pumping test in borehole UE-25c \#3, May to June 1984.

Assuming $b=$ the thickness of transmissive intervals (table 6):

$$
K_{r}=T / b=\frac{270 f t^{2} / d}{899 f t}=0.3 f t / d
$$

Flattening of a log-log plot of drawdown as a function of time since pumping started implies that a recharge boundary exists very close to borehole UE-25c \#3. Hence, the solution of Cooper (1963) was applied to the drawdown data. Fit to the type curve for $v=0.1$, the drawdown data from borehole UE-25c \#3 after the pump was restarted (fig. 21) indicated the following values of transmissivity and horizontal hydraulic conductivity:

$$
T=\frac{Q \times L(\mu, v)}{4 \pi s}=\frac{414 \mathrm{gal} / \mathrm{min} \times 192.5 f t^{3} / d \times 1}{4 \pi \times 21 \mathrm{ft} \times 1 \mathrm{gal} / \mathrm{min}}=300 \mathrm{ft}^{2} / d
$$

If $b$ is assumed to equal the total thickness of transmissive intervals in the borehole,

$$
K_{r}=T / b=\frac{300 f t^{2} / d}{899 f t}=0.3 f t / d
$$

The drawdown and recovery data obtained from borehole UE-25c \#2 could be interpreted to conform to the analytical solution of either Streltsova-Adams (1978) for a fissure-block aquifer or Neuman (1975) for an unconfined, anisotropic aquifer. For both analyses, the distance between boreholes UE-25c \#2 and UE-25c \#3 (r) was considered to be the average distance between the open sections of the boreholes. Taking into account the drift of both boreholes, the average interborehole distance was determined from gyroscopic surveys to be $95 \mathrm{ft}$.

For the analytical solution of Streltsova-Adams (1978), the parameter $\mathrm{r} / \mathrm{B}$ was estimated as follows:

1. Half the average distance between fractures in transmissive intervals (from Supplementary Data section) $=1.7 \mathrm{ft}$

2. Log-mean matrix hydraulic conductivity (from pl. 2) $=0.0004 \mathrm{ft} / \mathrm{d}$

3. Transmissivity (from the slope of late-time data on a plot of recovery as a function of time during this pumping test) $=25,000 \mathrm{ft}^{2} / \mathrm{d}$

$$
\frac{r}{B}=\frac{r}{\sqrt{\frac{T \times H}{K_{b}}}}=\frac{95 f t}{\sqrt{\left(\frac{25,000 f^{2} / d \times 1.7 f t}{0.0004 f t / d}\right)}}=0.009
$$

Fit to the type curve for $\eta=10$ and $r / B=0.05$, the drawdown data from borehole UE-25c \#2 after the pump was restarted (fig. 22) indicated the following values of transmissivity $(T)$, fracture storativity $\left(S_{f}\right)$, block storativity $\left(S_{b}\right)$, fracture hydraulic conductivity $\left(K_{f}\right)$, and block hydraulic conductivity $\left(K_{b}\right)$ :

$$
\begin{gathered}
T=\frac{Q \times W(\theta)}{4 \pi s}=\frac{414 \mathrm{gal} / \mathrm{min} \times 192.5 \mathrm{ft}^{3} / d \times 1}{4 \pi \times 0.22 \mathrm{ft} \times 1 \mathrm{gal} / \mathrm{min}}=29,000 \mathrm{ft}^{2} / d \\
K_{f}=\frac{T}{b}=\frac{29,000 \mathrm{ft}^{2} / d}{544 \mathrm{ft}}=50 \mathrm{ft} / d \\
S_{f}=\frac{4 T t}{r_{\theta}}=\frac{4 \times 29,000 \mathrm{ft}^{2} / \mathrm{d} \times 0.49 \mathrm{~min}}{(95 f t)^{2} \times 1 \times 1,440 \mathrm{~min} / d}=0.004 \\
S_{b}=S_{f} \times(\eta-1)=0.004 \times(10-1)=0.04 \\
B=\frac{r}{B}=0.05 \\
\frac{r}{0.05}=\frac{95 \mathrm{ft}}{0.05}=1,900 \mathrm{ft}
\end{gathered}
$$




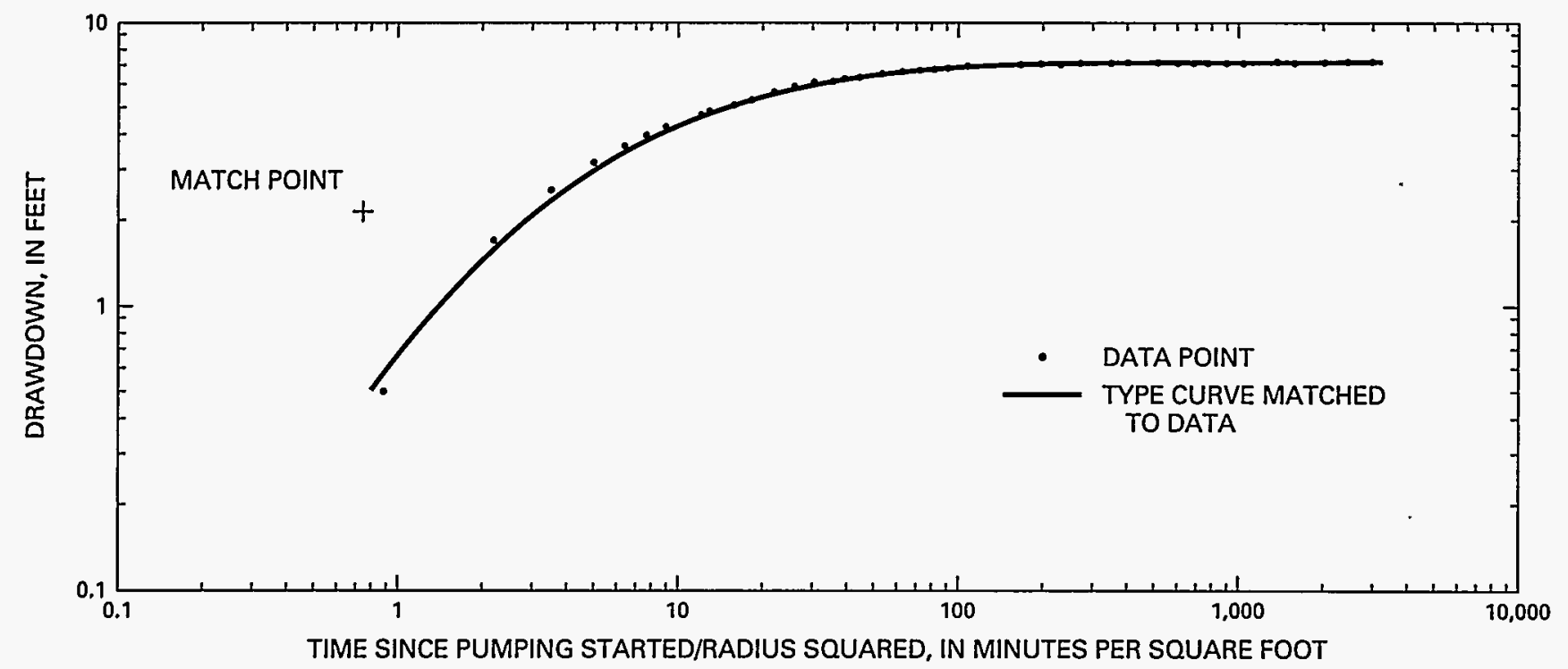

Figure 21. Analytical solution for drawdown data from borehole UE-25c \#3 assuming an infinite, homogeneous, isotropic, confined aquifer with leakage from a confining unit without storage, pumping test in borehole UE-25c \#3, May to June 1984.

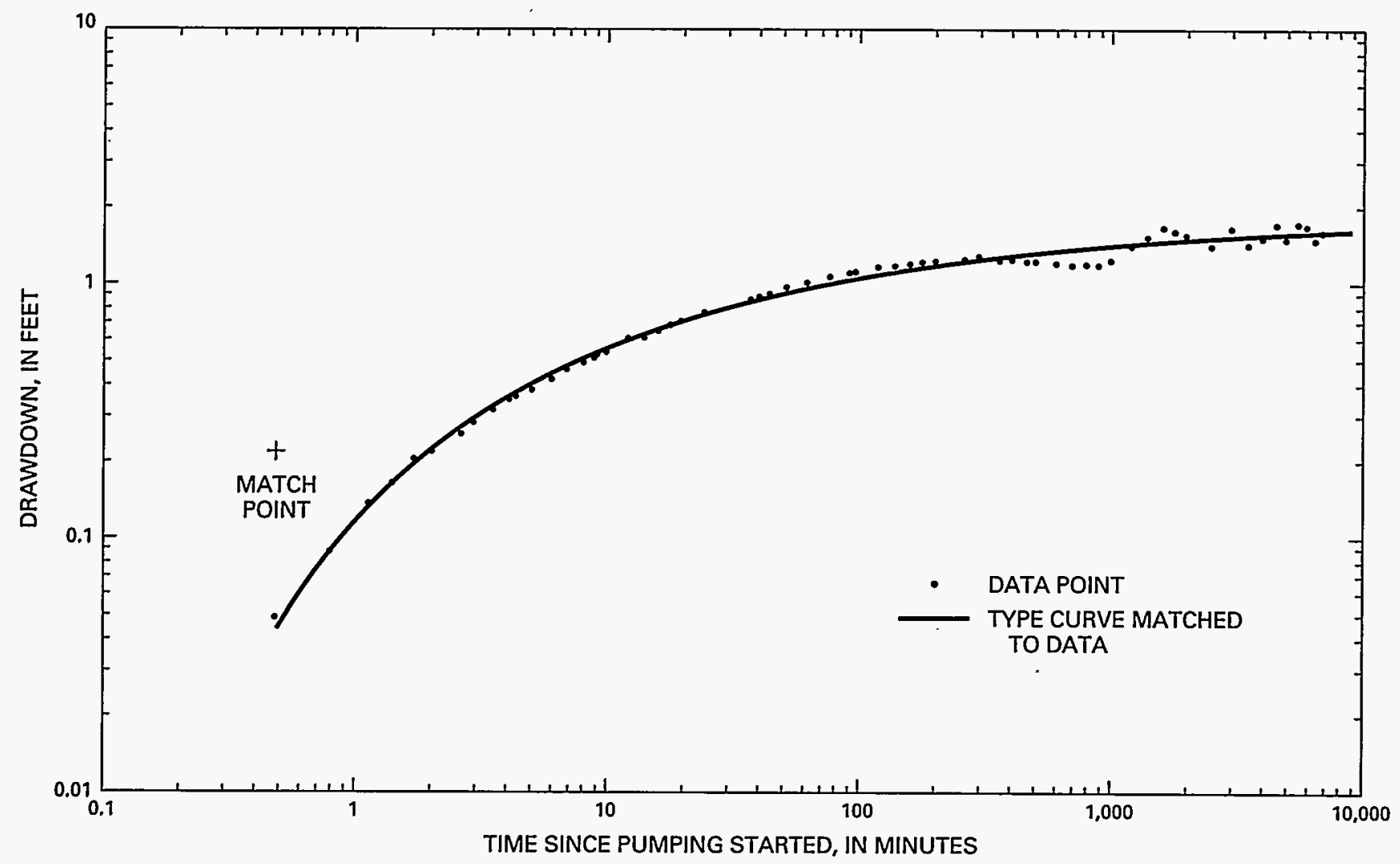

Figure 22. Analytical solution for drawdown data from borehole UE-25c \#2 assuming a fissure-block aquifer, pumping test in borehole UE-25c \#3, May to June 1984. 


$$
K_{b}=\frac{T \times H}{B^{2}}=\frac{29,000 f t^{2} / d \times 1.7 f t}{(1,900 f t)^{2}}=0.01 f t / d
$$

For the analytical solution of Neuman (1975), it was assumed that the vertical hydraulic-conductivity profile determined by injection tests in borehole
UE-25c \#1 applied, also, in UE-25c \#2. Consequently, values of vertical hydraulic conductivity $\left(K_{z}\right)$, horizontal hydraulic conductivity $\left(K_{r}\right)$, and the parameter $B$ in the first pumping test in UE-25c \#3 were estimated for borehole UE-25c \#2 as follows:

$$
K_{z}=\frac{b}{\sum_{i=1}^{i} \frac{b_{i}}{\bar{K}_{i}}}
$$

$K_{z}=\frac{1,625}{(70 / 2+55 / 0.6+135 / 0.4+80 / 0.2+250 / 0.08+345 / 0.05+145 / 0.03+175 / 0.01+105 / 0.008+190 / 0.005+75 / 0.003)}$

$$
K_{z}=0.015 f t / d
$$

$$
K_{r}=\frac{\sum_{i=1}^{i} K_{i} b_{i}}{b}
$$

$K_{r}=\frac{(70 \times 2+55 \times 0.6+135 \times 0.4+80 \times 0.2+250 \times 0.08+345 \times 0.05+145 \times 0.03+175 \times 0.01+105 \times 0.008+190 \times 0.005+75 \times 0.003)}{1,625}$

$$
K_{r}=0.18 f t / d
$$


Assuming $\mathrm{b}=$ the thickness of transmissive intervals in borehole UE-25c \#2:

$$
\beta=\frac{K_{z}{ }^{2}}{K_{r} b^{2}}=\frac{0.015 f t / d \times(95 f t)^{2}}{0.18 f t / d \times(544 f t)^{2}}=0.003
$$

Fit to the type curve for $B=0.004$, the drawdown data from borehole UE-25c \#2 after the pump was restarted (fig. 23) indicated the following values of transmissivity $(T)$, storativity $(S)$, specific yield $\left(S_{y}\right)$, horizontal hydraulic conductivity, vertical hydraulic conductivity, and anisotropy $\left(K_{z} / K_{r}\right)$ :

$$
\begin{gathered}
T=\frac{Q \times W\left(\mu_{A}, \mu_{B}, \beta\right)}{4 \pi s} \\
T=\frac{414 \mathrm{gal} / \mathrm{min} \times 192.5 f t^{3} / d \times 1}{4 \pi \times 0.27 f t \times 1 \mathrm{gal} / \mathrm{min}}=23,000 \mathrm{ft}^{2} / d \\
S=\frac{4 T t \mu_{A}}{r^{2}}=\frac{4 \times 23,000 \mathrm{ft}^{2} / d \times 0.6 \mathrm{~min} \times 1}{(95 f t)^{2} \times 1,440 \mathrm{~min} / d}=0.004 \\
S_{Y}=\frac{4 T t \mu_{B}}{r^{2}}=\frac{4 \times 23,000 f_{t}^{2} / d \times 9.7 \mathrm{~min} \times 1}{(95 f t)^{2} \times 1,440 \mathrm{~min} / d}=0.07
\end{gathered}
$$

Assuming $b=$ thickness of transmissive intervals:

$$
\begin{gathered}
K_{r}=T / b=\frac{23,000 f t^{2} / d}{544 f t}=40 f t / d \\
K_{z}=\frac{K_{r} b^{2} \beta}{r^{2}}=\frac{40 f t / d \times(544 f t)^{2} \times 0.004}{(95 f t)^{2}} \\
K_{z}=5 f t / d \\
K_{z} / K_{r}=\frac{5 f t / d}{40 f t / d}=0.1
\end{gathered}
$$

Both the drawdown data from borehole UE-25c \#1 above the packers and the recovery data from borehole UE-25c \#1 between the packers unambiguously conform to type curves of Neuman (1975) for an unconfined, anisotropic aquifer (figs. 24 and 25). From a heat-pulse flowmeter survey done in December 1991 , it was estimated that tuffaceous rocks above the packers contribute four percent of the discharge from the entire thickness of rocks below casing and concrete in borehole UE-25c \#1, and tuffaceous rocks between the packers contribute 0.5 percent of this discharge. Therefore, for the interval above the packers the fol- lowing values of transmissivity $(T)$ and specific yield $\left(S_{y}\right)$ were calculated:

$$
\begin{gathered}
T=\frac{Q \times W\left(\mu_{A}, \mu_{B}, \beta\right)}{4 \pi s}=\frac{\left(0.04 \times 418 \mathrm{gal} / \mathrm{min} \times 192.5 f t^{3} / d\right) \times 1}{(4 \pi \times 4.5 f t) \times 1 \mathrm{gal} / \mathrm{min}}=60 f t^{2} / d \\
S_{Y}=\frac{4 T t \mu_{B}}{r^{2}}=\frac{4 \times 60 f t^{2} / d \times 480 \mathrm{~min} \times 1}{(256 f t)^{2} \times 1440 \mathrm{~min} / d}=0.001
\end{gathered}
$$

For the interval between the packers, the following values of transmissivity and specific yield were calculated:

$$
\begin{gathered}
\Gamma=\frac{Q \times W\left(\mu_{A^{\prime}} \mu_{B}, \beta\right)}{4 \pi s}=\frac{\left(0.005 \times 418 \mathrm{gal} / \mathrm{min} \times 192.5 f t^{3} / d\right) \times 1}{(4 \pi \times 0.74 f t) \times 1 \mathrm{gal} / \mathrm{min}}=40 \mathrm{ft}^{2} / \mathrm{a} \\
S_{Y}=\frac{4 T t \mu_{B}}{r^{2}}=\frac{4 \times 40 \mathrm{ft}^{2} / \mathrm{d} \times 1,100 \mathrm{~min} \times 1}{(259 f)^{2} \times 1,440 \mathrm{~min} / \mathrm{d}}=0.002
\end{gathered}
$$

From the drawdown data and thickness of transmissive intervals above the packers,

$$
\beta=r^{2} / b^{2} \times K_{z} / K_{r}=4.0
$$

$$
K_{z} / K_{r}=\frac{4.0 \times b^{2}}{r^{2}}=\frac{4.0 \times(182 f t)^{2}}{(256 f t)^{2}}=2
$$

Fracture data from between the packers were insufficient to calculate unequivocally the thickness of transmissive intervals between the packers. Therefore, average values of horizontal hydraulic conductivity $\left(K_{r}\right)$ and vertical hydraulic conductivity $\left(K_{z}\right)$ were calculated for the Calico Hills aquifer (the intervals above and between the packers in borehole UE-25c \#1) by assuming that the value of anisotropy $\left(K_{z} / K_{r}\right)$ obtained above the packers applies, also, to the interval between the packers.

Adding the transmissivity values for the intervals above and between the packers gives a composite transmissivity of $100 \mathrm{ft}^{2} / \mathrm{d}$ for the Calico Hills aquifer. Dividing this transmissivity value by the known thickness of transmissive intervals above and between the packers, $198 \mathrm{ft}$, gives a horizontal hydraulic conductivity value of $0.5 \mathrm{ft} / \mathrm{d}$ for the Calico Hills aquifer. If $K_{z} / K_{r}=2$, then the vertical hydraulic conductivity of the Calico Hills aquifer $=2 K_{r}=2 \times 0.5 \mathrm{ft} / \mathrm{d}=1 \mathrm{ft} / \mathrm{d}$. 


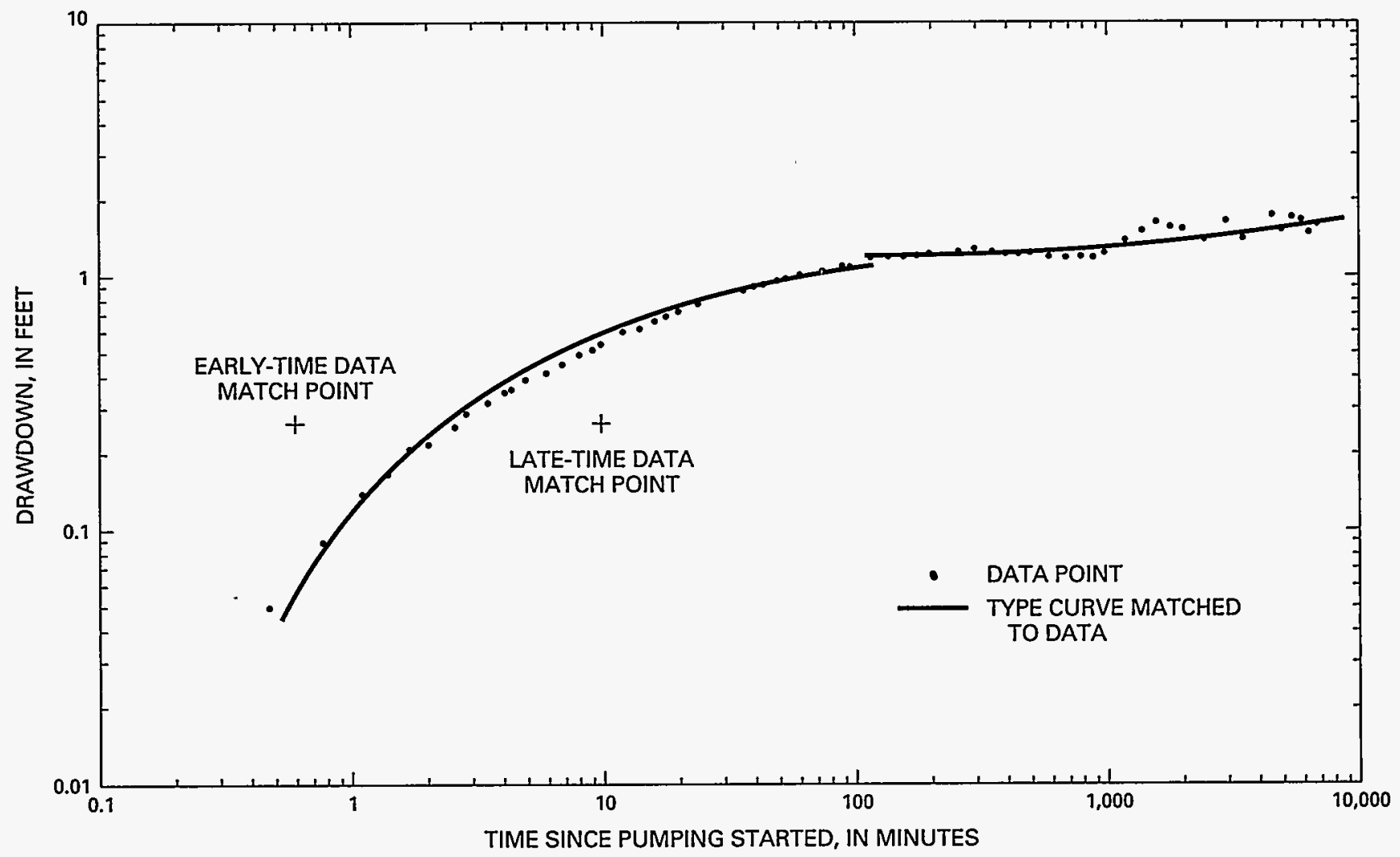

Figure 23. Analytical solution for drawdown data from borehole UE-25c \#2 assuming an infinite, homogeneous, anisotropic, unconfined aquifer, pumping test in borehole UE-25c \#3, May to June 1984.

56 Results and Interpretation of Preliminary Aquifer Tests in Boreholes UE-25c \#1, UE-25c \#2, and UE-25c \#3, Yucca Mountain, Nye County, Nevada 


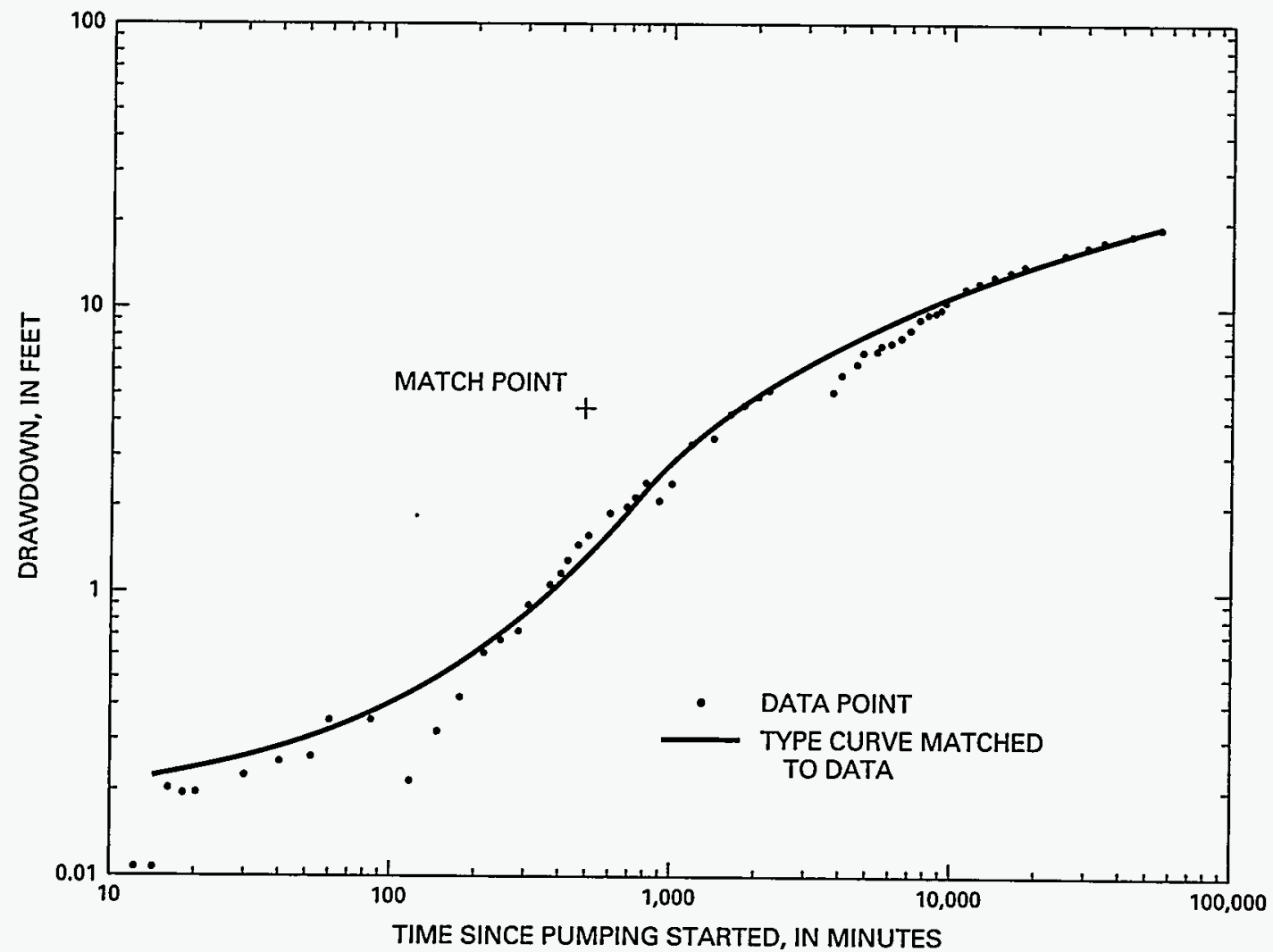

Figure 24. Analytical solution for drawdown data from borehole UE-25c \#1 above the packers assuming an infinite, homogeneous, anisotropic, unconfined aquifer, pumping test in borehole UE-25c \#3, May to June 1984.

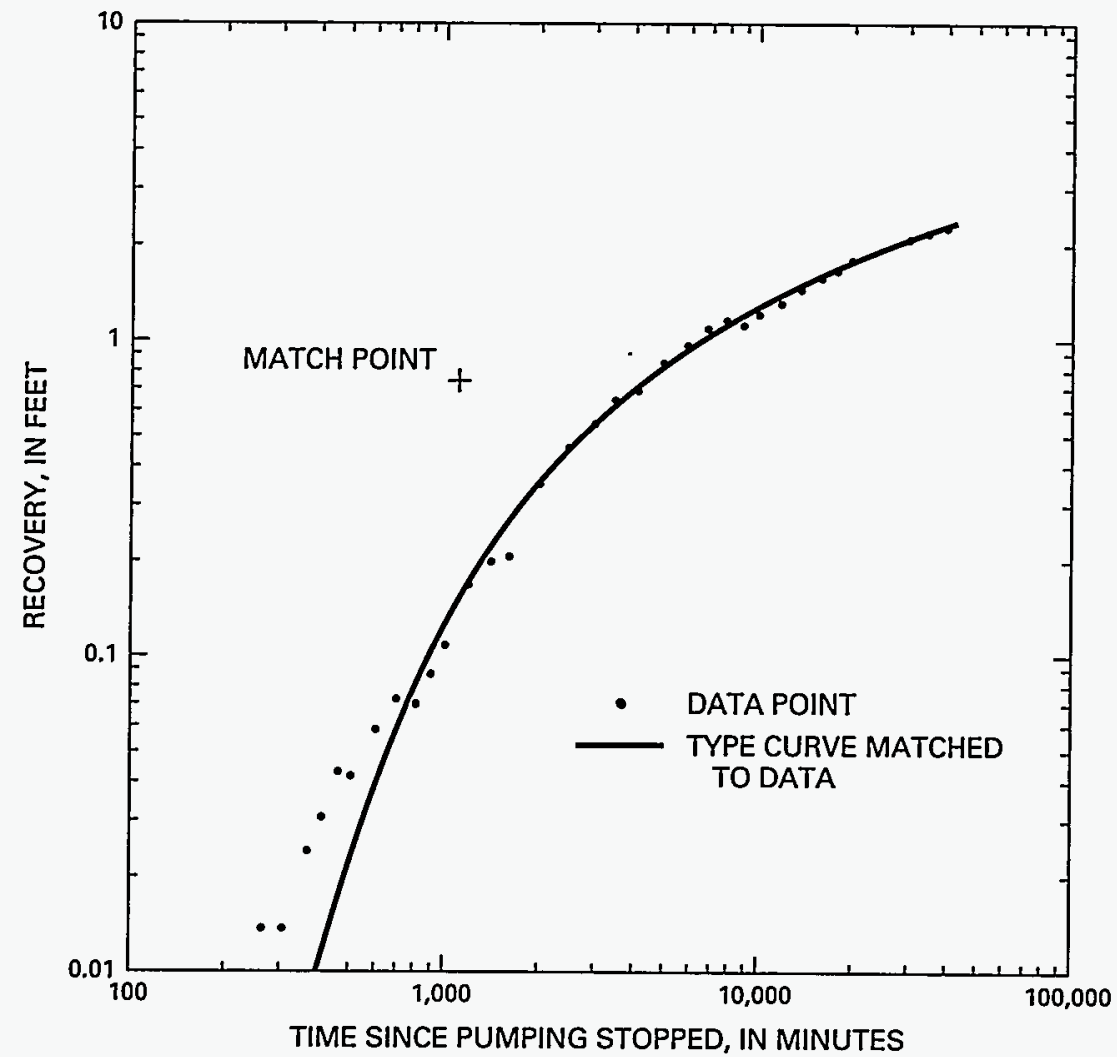

Figure 25. Analytical solution for recovery data from borehole UE-25c $\# 1$ between the packers assuming an infinite, homogeneous, anisotropic, unconfined aquifer, pumping test in borehole UE-25c \#3, May to June 1984. 


\section{Injection Test in Borehole UE-25c \#2}

An injection test was conducted in borehole UE-25c \#2 from 1351 to 1520 on October 30, 1984, to ascertain hydrologic properties of an interval in borehole UE-25c \#2 that was thought to contain very permeable rock (the Bullfrog aquifer). The injection test was conducted using monitoring equipment installed for a pumping test in borehole UE-25c \#3 that began 156 minutes after the injection test ended.

In the injection well, borehole UE-25c \#2, straddle packers were installed on a 2.9-in-diameter plastic tube to isolate the Bullfrog aquifer (Fenix and Scisson, Inc., written commun., 1984). The interval between the packers extended from 2,364 to $2,475 \mathrm{ft}$ below the land surface. Above the packers, from 1,365 to $2,355 \mathrm{ft}$ below the land surface, the borehole was open in the Calico Hills aquifer, the Prow Pass-upper Bullfrog aquifer, and confining units between and below the two aquifers. Below the packers, from 2,484 to $2,990 \mathrm{ft}$ below land surface, the borehole was open in the Tram aquifer and the overlying confining unit. Hydraulic heads above, between; and below the packers were monitored with GRC temperature-compensated, pressure transducers with recording ranges of 0 to 2,500 and 0 to $5,000 \mathrm{lb} / \mathrm{in} .^{2}$, that were connected at the surface to a HP-85 data logger (USGS logbook for the c-holes, 1984-1985, unpublished). During the test, water was injected between the packers from a Baker tank to maintain a constant pressure head of $778 \mathrm{ft}$ (USGS records, unpublished). Because the injection rate quickly stabilized at $167 \mathrm{gal} / \mathrm{min}$ (USGS logbook for the c-holes, 1984-1985, unpublished), what was intended to be a constant-head test was converted to a constant-flux test, and the effects of this flux were monitored in borehole UE-25c \#1, UE-25c \#2, and UE-25c \#3 (Devin L. Galloway, USGS, oral commun., 1993).

Borehole UE-25c \#1 was monitored above, between, and below straddle packers hung on a 2.9-in.-diameter plastic tube (Fenix and Scisson, Inc., written commun., 1984). Above the packers, from 1,371 to $2,514 \mathrm{ft}$ below land surface, the borehole was open from the Calico Hills aquifer to the top of the Bullfrog aquifer. Between the packers, from 2,524 to $2,594 \mathrm{ft}$ below land surface, the borehole was open in the Bullfrog aquifer. Below the packers, from 2,603 to $2,962 \mathrm{ft}$ below land surface, the borehole was open in the Tram aquifer and overlying confining unit. Hydraulic heads in borehole UE-25c \#1 were monitored with GRC temperature-compensated, pressure transducers with recording ranges of 0 to 2,500 and 0 to $5,000 \mathrm{lb} /$ in. $^{2}$, that were connected at the surface to a HP-85 data logger (USGS logbook for the c-holes,
1984-1985, unpublished). Before the test began, borehole UE-25c \#1 was shut in to minimize barometric effects.

Borehole UE-25c \#3 was open in the tuffs and lavas of Calico Hills and the Crater Flat Tuff, from the bottom of concrete, at a depth of $1,368 \mathrm{ft}$, to the bottom of the borehole, at a depth of $2,976 \mathrm{ft}$. The pump installation was the same as it was in the May-June 1984 pumping test in borehole UE-25c \#3. Depth to water in the borehole was monitored with a Bell and Howell pressure transducer with a recording range of 0 to $50 \mathrm{lb} / \mathrm{in}^{2}$, that was suspended inside a 2.4-in.diameter access tube and connected at the surface to a Fluke data logger (USGS logbook for the c-holes, 1984-1985, unpublished). The calibrated depth of the transducer was $1,320 \mathrm{ft}$ below the top of the access tube, $100 \mathrm{ft}$ below the static water level inside the tube (USGS records, unpublished).

Injection of water between the packers in borehole UE-25c \#2 caused the water level to rise about $4.0 \mathrm{ft}$ in borehole UE-25c \#2 above the packers (fig. 26), $0.7 \mathrm{ft}$ in borehole UE-25c \#1 between the packers, $0.1 \mathrm{ft}$ in borehole UE-25c \#1 above and below the packers, and $0.4 \mathrm{ft}$ in borehole UE-25c \#3 (fig. 27). After injection ended, water-level recovery to pre-test static levels was complete in all monitored intervals in boreholes UE-25c \#1 and UE-25c \#3 within 90 minutes. However, in borehole UE-25c \#2, water level recovery above the packers was only 69 percent complete when a pumping test began in borehole UE-25c \#3, 156 minutes after injection ended. As indicated in figure 26, residual drawdown from the injection test is estimated to have had an effect on the water level in borehole UE-25c \#2 above the packers for the first 515 minutes of the pumping test. Possibly because injection changed fracture apertures in the injection interval, the hydraulic head between the packers was $1.6 \mathrm{ft}$ lower than the pre-injection test static level and still falling when the pumping test in borehole UE-25c \#3 started (fig. 27). Post-pumping test data indicate that the hydraulic head between the packers probably would have stabilized asymptotically with time at a level about $2.5 \mathrm{ft}$ lower than before the injection test started, had the pumping test in borehole UE-25c \#3 not been conducted.

Most of the data from the injection test were not analyzed. The head build-up in borehole UE-25c \#2 above the packers (fig. 26) was erratic and indicative of possible mechanical problems. The head build-up in borehole UE-25c \#1 above and below the packers (fig. 27) was insignificant. Although the head build-up in borehole UE-25c \#1 between the packers (fig. 27) was large and steady enough to be analyzed, the data were considered less reliable than recovery data 


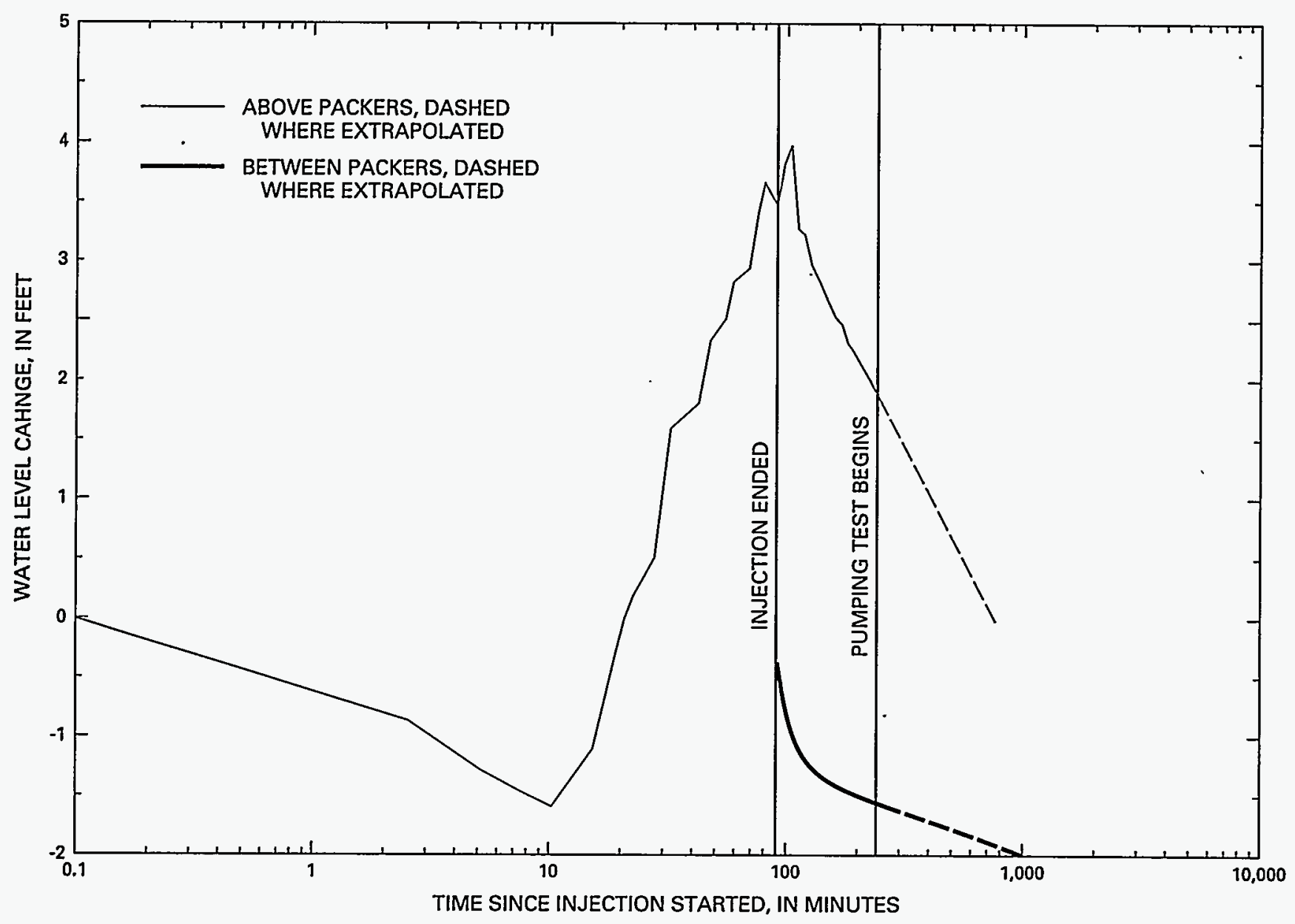

Figure 26. Water-level changes in borehole UE-25c \#2 during and after injection of water between packers on October 30, 1984. 


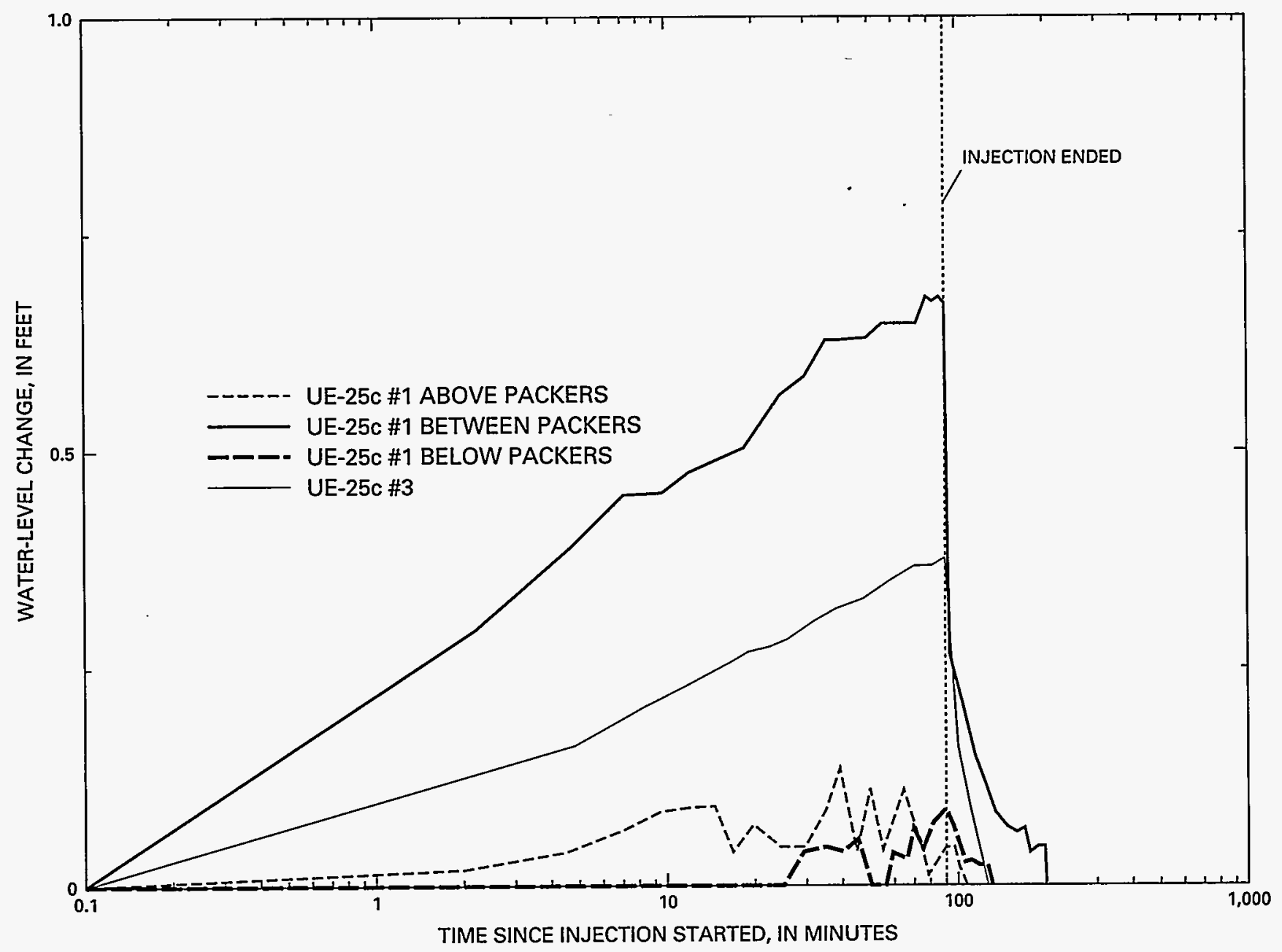

Figure 27. Water-level changes in boreholes UE-25c \#1 and UE-25c \#3 in response to injection of water into borehole UE-25c \#2, October 30, 1984. 
obtained from the same interval during the subsequent pumping test in borehole UE-25c \#3. Consequently, the data from UE-25c \#1 between the packers were not analyzed. Only the data from borehole UE-25c \#3 were analyzed because no comparable data were obtained from this borehole in any other constant-flux tests (This was the only test in which borehole UE-25c \#3 was used as an observation well).

The composite transmissivity $(T)$, storativity $(S)$, and hydraulic conductivity $\left(K_{r}\right)$ of the tuffaceous rocks in borehole UE-25c \#3 could be determined from the head build-up data shown in figure 27 assuming an infinite, homogeneous, isotropic, confined aquifer. Using the method of Cooper and Jacob (1946) and equations 12 and 13, the following calculations were made:

$$
\begin{gathered}
T=\frac{2.3 Q}{4 \pi \Delta s_{d}}=\frac{2.3 \times 167 \mathrm{gal} / \mathrm{min} \times 192.5 f t^{3} / d}{4 \pi \times(0.40-0.23) f t \times 1 \mathrm{gal} / \mathrm{min}}=35,000 \mathrm{ft}^{2} / d \\
S=\frac{2.25 t_{0}}{r^{2}}=\frac{2.25 \times 35,000 \mathrm{ft}^{2} / \mathrm{d} \times 0.42 \mathrm{~min}}{(95 f t)^{2} \times 1,440 \mathrm{~min} / \mathrm{d}}=0.002
\end{gathered}
$$

Assuming $b$ to be the thickness of transmissive intervals:

$$
K_{r}=T / b=\frac{35,000 f t^{2} / d}{899 f t}=40 f t / d
$$

Values of transmissivity and hydraulic conductivity determined for the rocks in borehole UE-25c \#3 from the injection test are two orders of magnitude larger than values determined from the drawdown in borehole UE-25c \#3 during the pumping test in this borehole in May-June 1984. Yet, the transmissivity determined from the pumping test in borehole $\mathrm{UE}-25 \mathrm{c} \# 3$ is the same, to one significant figure, as the composite transmissivity determined in borehole UE-25c\#1 from fluid-injection tests ( $\left.261 \mathrm{ft}^{2} / \mathrm{d}\right)$. Larger values of transmissivity and hydraulic conductivity apparently are determined as the radius of investigation expands and encompasses more conduits for groundwater flow, such as faults and fracture zones. Crosshole tests indicate site-scale hydrologic properties, whereas single-well tests indicate hydrologic properties within a small radius of the pumping or injection well. Consequently, the remainder of this report emphasizes analyses of data obtained from observation wells.

\section{Second Pumping Test in Borehole UE-25c \#3}

A second pumping test was conducted in borehole UE-25c \#3 from October-December 1984, primarily to determine vertical and lateral variations in hydrologic properties of the Crater Flat Tuff. In addition to the monitoring network for the injection test described in the previous section, a piezometer was monitored in borehole UE-25p \#1, and a recording barometer was maintained at borehole USW H-4. Because the piezometer record from borehole UE-25p \#1 indicated an erratic but progressive increase in hydraulic head throughout the entire two weeks that borehole UE-25c \#3 was pumped, it is believed that the transducer installed in borehole UE-25p \#1 was miscalibrated or malfunctioned during this pumping test. The barometric record obtained at borehole USW H-4 (fig. 28) was not used to correct drawdown data, because head changes in the $c$-holes were considered large enough that atmospheric pressure changes probably would have had little or no effect on data analyses.

\section{Procedures and Problems}

Pumping in borehole UE-25c \#3 began at 1756 on October 30,1984, and continued until 1342 on November 15, 1984, a period of about 15.8 days (USGS records, unpublished). The test was interrupted by an 8.3 minute pump failure on November 2, 1984 $(3,839$ minutes into the test), which caused a 97 percent recovery of the water level in the pumped well but only slight (4-8 percent) recovery in monitored intervals of boreholes UE-25c \#1 and UE-25c \#2 (USGS records, unpublished). During the first few hours of the test, the discharge rate varied from 400 to $410 \mathrm{gal} / \mathrm{min}$, but for most of the test, the discharge rate varied from 422 to $429 \mathrm{gal} / \mathrm{min}$ (USGS logbook for the c-holes, 19841985 , unpublished). At an average discharge rate of $425 \mathrm{gal} / \mathrm{min}$, a volume of 9,675,942 gallons of water was withdrawn during the test (USGS logbook for the c-holes, 1984-1985, unpublished).

In addition to the pump failure, the second pumping test in borehole UE-25c \#3 was hampered by several other mechanical problems and the short interval between the injection test in borehole UE-25c \#2 described previously and the pumping test. The transducer in borehole UE-25c \#2 below the packers was inoperative for the entire pumping test, and the transducer in borehole UE-25c \#1 between the packers intermittently gave spurious readings (USGS logbook for the c-holes, 1984-1985, unpublished; USGS records unpublished). During the first few days of the test, the discharge meter was slightly inaccurate 


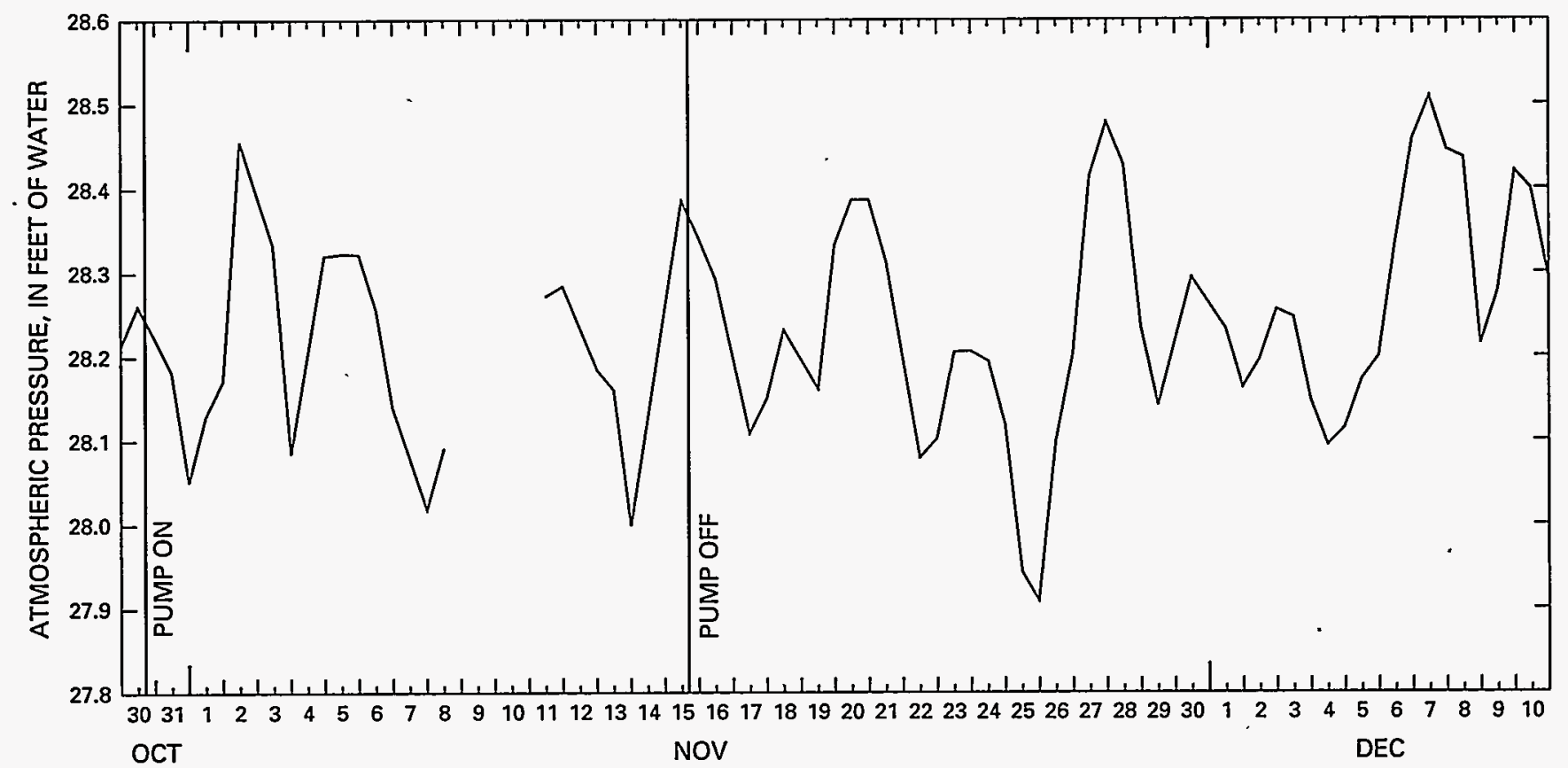

Figure 28. Atmospheric pressure at borehole USW H-4 during the pumping test in borehole UE-25c \#3, October to December 1984.

because of leakage through a fitting in the discharge line (USGS logbook for the c-holes, 1984-1985, unpublished). Oscillations in the power supply coupled with Earth tides caused diurnal fluctuations in recorded drawdown (USGS records, unpublished). Problems with data loggers caused intermittent losses of drawdown and recovery data (USGS logbook for the c-holes, 1984-1985, unpublished). In borehole UE-25c \#2 above the packers, a 13-ft head decrease followed by a 7 -ft head increase occurred as borehole UE-25c \#3 was being pumped. Regardless of whether the head increase during pumping resulted from antecedent effects of the preceding injection test, changing hydrologic conditions during pumping (e.g..boundary effects), or a transducer malfunction, the entire record from borehole UE-25c \#2 above the packers is suspect. Consequently, this record could not be analyzed to determine hydrologic properties. Finally, antecedent drawdown from the injection test required a correction to the recorded drawdown data from borehole UE-25c \#2 between the packers for these data to be used to calculate hydrologic properties. The antecedent drawdown trend was estimated by extrapolation between drawdown values recorded prior to pumping and apparent steady-state drawdown values obtained 23.7 days after pumping ceased.

As in the first pumping test in borehole UE-25c \#3 (fig. 18A), turning the pump on and off dur- ing the second pumping test in this borehole caused rapid, large changes in the water level in the pumped well (fig. 29). Ten minutes after pumping began, the water level in borehole UE-25c \#3 had decreased $61 \mathrm{ft}$; when the pump was turned off, the water level rose about $65 \mathrm{ft}$ in ten minutes. Maximum drawdown in the pumped well during this test was about $65 \mathrm{ft}$ (USGS records, unpublished).

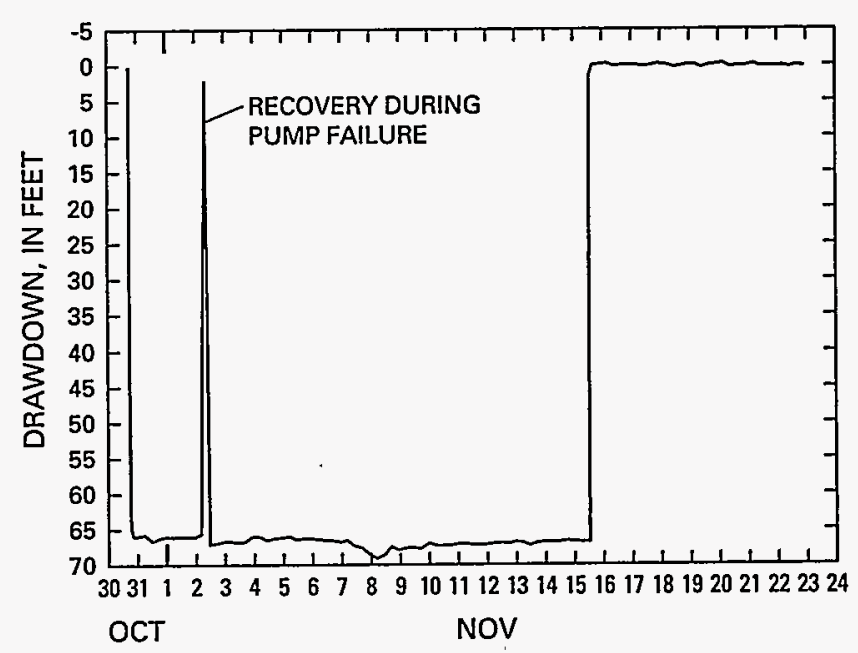

Figure 29. Drawdown as a function of time in borehole UE-25c \#3 during the pumping test in borehole UE-25c \#3, October to December 1984. 
The drawdown in monitored intervals of borehole UE-25c \#1 caused by pumping borehole UE-25c \#3 was much slower and smaller than in the pumped well (USGS records, unpublished). The maximum drawdown in borehole UE-25c \#1 above the packers was about $1.1 \mathrm{ft}$; the maximum drawdown between the packers was about $2.2 \mathrm{ft}$; and the maximum drawdown below the packers was about $3.15 \mathrm{ft}$ (fig. 30). Water-level recovery in the pumped well was complete 444 minutes after pumping ceased (fig. 29), but complete recovery in monitored intervals of borehole UE-25c \#1 required 20.7 to 21.7 days (fig. 30).

Similar to borehole UE-25c \#1 between the packers, the maximum drawdown in borehole UE-25c \#2 between the packers after correcting for residual drawdown from the injection test was about $2.3 \mathrm{ft}$ (USGS records, unpublished). Complete recovery in borehole UE-25c \#2 between the packers occurred 23.7 days after pumping ceased (fig. 31).

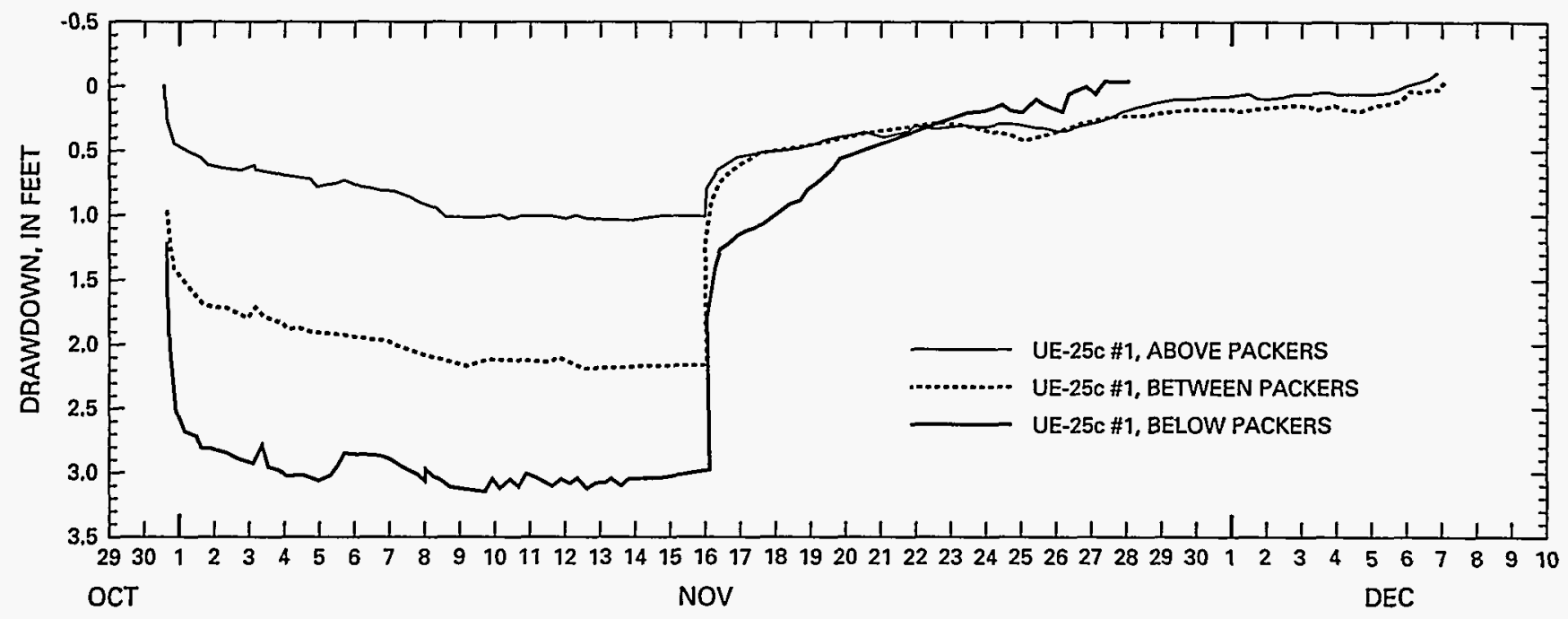

Figure 30. Drawdown as a function of time in borehole UE-25c \#1 during the pumping test in borehole UE-25c \#3, October to December 1984.

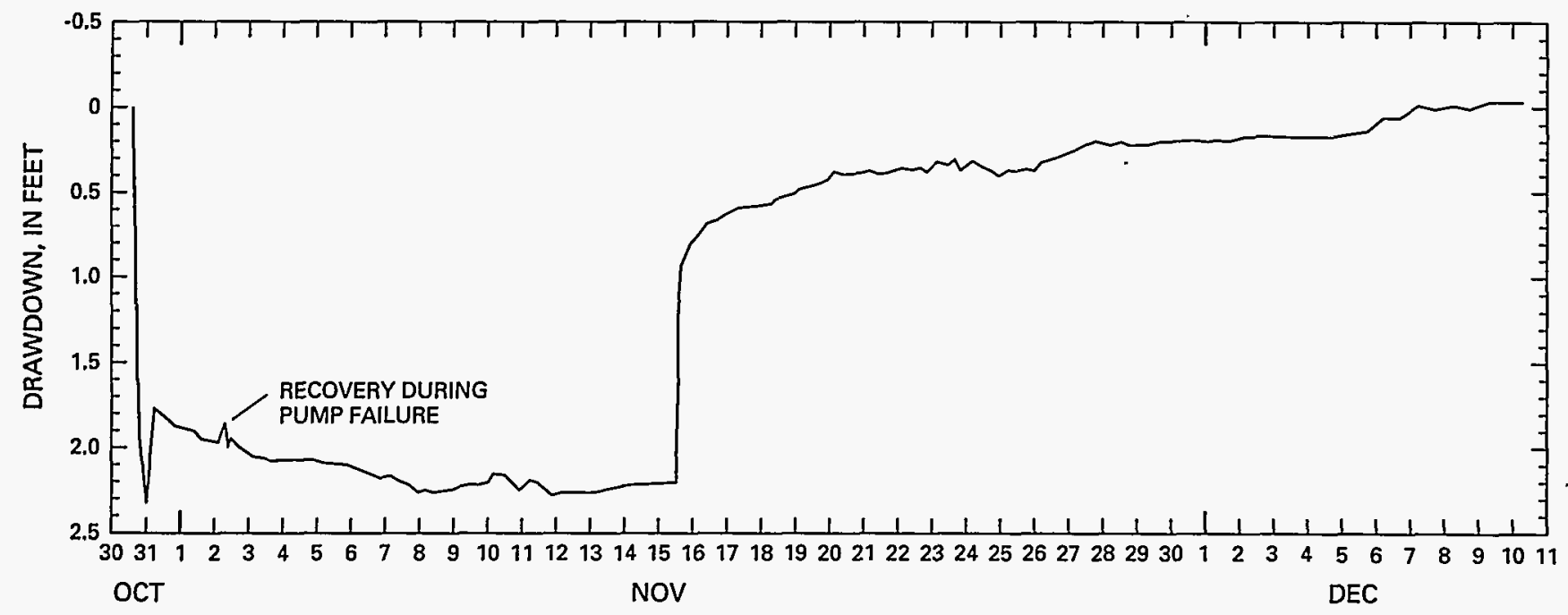

Figure 31. Drawdown as a function of time in borehole UE-25c \#2 between the packers during the pumping test in borehole UE-25c \#3, October to December 1984, with residual drawdown from a preceding injection test subtracted. 


\section{Test Analyses}

The second pumping test in borehole UE-25c \#3 produced analyzable data sets from boreholes UE-25c \#3, UE-25c \#2 between the packers, and UE-25c \#1 above, between, and below the packers. Analyses of the data from the pumped well, borehole UE-25c \#3, produced nearly identical results as analyses of data from this borehole obtained during the first pumping test in the borehole. To avoid redundancy, analyses of data from the pumped well obtained during the second pumping test in the borehole are not discussed further in this report. The remaining data sets are discussed with respect to the hydrogeologic intervals tested, instead of by borehole.
For drawdown and recovery data from borehole UE-25c \#1 above the packers, the pumping test in borehole UE-25c \#2 indicated that using the analytical solution of Neuman (1975) for an unconfined aquifer and matching the data curve to the type curve for $B=0.06$ provided the most reasonable calculations of hydrologic properties. Therefore, in the second pumping test in borehole UE-25c \#3, drawdown data from borehole UE-25c \#1 above the packers again were matched to the type curve of Neuman (1975) for $B=0.06$ (fig. 32), and the following values of transmissivity $(T)$, storativity $(S)$, specific yield $\left(S_{y}\right)$, horizontal hydraulic conductivity $\left(K_{r}\right)$, vertical hydraulic conductivity $\left(K_{z}\right)$, and anisotropy $\left(K_{z} / K_{r}\right)$ were calculated:

$$
\begin{gathered}
T=\frac{Q \times W\left(\mu_{A}, \mu_{B}, \beta\right)}{4 \pi s}=\frac{\left(0.125 \times 425 \mathrm{gal} / \mathrm{min} \times 192.5 f t^{3} / d\right) \times 1}{(4 \pi \times 0.21 \mathrm{ft}) \times 1 \mathrm{gal} / \mathrm{min}}=3,900 f t^{2} / d \\
S=\frac{4 T t \mu_{A}}{r^{2}}=\frac{4 \times 3,900 f t^{2} / d \times 6.1 \mathrm{~min} \times 1}{(267 f t)^{2} \times 1,440 \mathrm{~min} / d}=0.0009 \\
S_{Y}=\frac{4 T t \mu_{B}}{r^{2}}=\frac{4 \times 3,900 f t^{2} / d \times 80 \mathrm{~min} \times 1}{(267 f)^{2} \times 1,440 \mathrm{~min} / d}=0.01 \\
K_{r}=T / b=\frac{3,900 f t^{2} / d}{528 f t}=7 f t / d \\
K_{z}=\frac{K_{r} b^{2} \beta}{r^{2}}=\frac{7 f t / d \times\left(528 f t^{2}\right) \times 0.06}{\left(267 f t^{2}\right)}=2 f t / d \\
K_{z} / K_{r}=2 / 7=0.3
\end{gathered}
$$




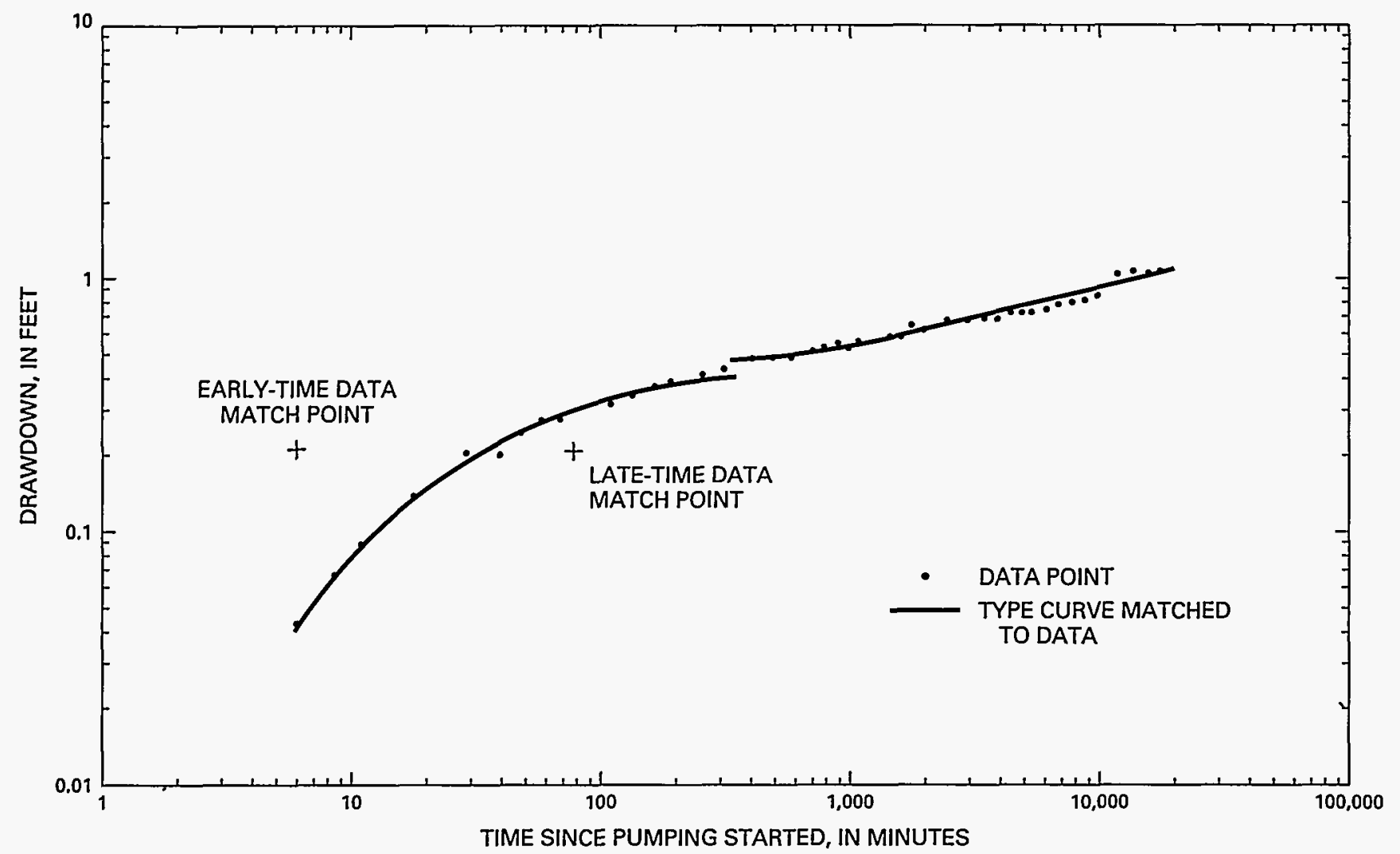

Figure 32. Analytical solution for drawdown data from borehole UE-25c \#1 above the packers assuming an infinite, homogeneous, anisotropic, unconfined aquifer, pumping test in borehole UE-25c \#3, October to December 1984.

The average transmissivity of the Prow Passupper Bullfrog aquifer was estimated to equal the average transmissivity of the rocks in borehole UE-25c \#1 above the packers minus the transmissivity of the Calico Hills aquifer, which was calculated as follows:

Transmissivity $\left(\mathrm{ft}^{2} / \mathrm{d}\right)$

UE-25c \#1 above packers, pumping test in borehole UE-25c \#2

UE-25c \#1 above packers, second pumping test in borehole UE-25c \#3

UE-25c \#1 above packers, average

Calico Hills aquifer

Prow Pass - upper Bullfrog aquifer

2,900

3,900

$\begin{array}{r}\hline 3,400 \\ -100 \\ \hline 3,300\end{array}$

The average horizontal hydraulic conductivity of the Prow Pass-upper Bullfrog aquifer, then, would be $3,300 \mathrm{ft}^{2} / \mathrm{d}$ divided by $326 \mathrm{ft}$ of transmissive rocks, which equals $10 \mathrm{ft} / \mathrm{d}$. Multiplying the average horizontal hydraulic conductivity of the Prow Pass-upper Bullfrog aquifer by the average anisotropy in borehole
UE-25c \#1 above the packers, 0.2 , indicates an average vertical hydraulic conductivity of $2 \mathrm{ft} / \mathrm{d}$ for the Prow Pass-upper Bullfrog aquifer.

As in the above calculations, the average specific yield of the Prow Pass-upper Bullfrog aquifer was estimated to equal the average specific yield of the rocks in borehole UE-25c \#1 above the packers minus the specific yield of the Calico Hills aquifer, which was calculated as follows:

UE-25c \#1 above packers, pumping test in Specifle yield borehole UE-25c \#2

UE-25c \#1 above packers, second pumping test in borehole UE-25c \#3

UE-25c \#1 above packers, average

0.004

Calico Hills aquifer

Prow Pass-upper Bullfrog aquifer

.01

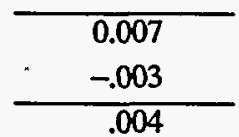

Recovery data obtained from boreholes UE-25c \#1 and UE-25c \#2 between the packers, both, 
conform to the type curve of Theis (1935) for an infinite, homogeneous, isotropic, confined aquifer (figs. 33 and 34) and indicate hydrologic properties for the Bullfrog aquifer. Based on heat-pulse flowmeter surveys done in December 1991, it was assumed that 29.5 percent of the flow in rocks below casing and con- crete in borehole UE-25c \#1 and 14 percent of the flow in rocks below casing and concrete in borehole UE-25c \#2 come from the packed-off intervals in these boreholes. The following calculations of transmissivity $(T)$, storativity $(S)$, and horizontal hydraulic conductivity $\left(K_{r}\right)$ were made:

\section{UE-25c \#1 Between Packers}

$$
\begin{aligned}
& T=\frac{Q \times W(\mu)}{4 \pi s} \\
& T=\frac{\left(0.295 \times 425 \mathrm{gal} / \mathrm{min} \times 192.5 f t^{3} / d\right) \times 1}{(4 \pi \times 0.23 f t) \times 1 \mathrm{gal} / \mathrm{min}} \\
& T=8,400 f t^{2} / d \\
& S=\frac{4 T t \mu}{r^{2}} \\
& S=\frac{4 \times 8,400 f t^{2} / d \times 7.0 \mathrm{~min} \times 0.1}{(280 f t)^{2} \times 1,440 \mathrm{~min} / d} \\
& S=0.0002 \\
& K_{r}=\frac{T / b}{K_{r}}=\frac{8,400 f t^{2} / d}{70 f t}=100 \mathrm{ft} / \mathrm{d}
\end{aligned}
$$

\section{UE-25c \#2 Between Packers}

$T=\frac{Q \times W(\mu)}{4 \pi s}$

$T=\frac{\left(0.14 \times 425 \mathrm{gal} / \mathrm{min} \times 192.5 f \mathrm{f}^{3} / d\right) \times 1}{(4 \pi \times 0.22 \mathrm{ft}) \times 1 \mathrm{gal} / \mathrm{min}}$

$T=4,100 f t^{2} / d$

$S=\frac{4 T t \mu}{r^{2}}$

$S=\frac{4 \times 4,100 f^{2} / d \times 5.6 \mathrm{~min} \times 0.1}{(92 \mathrm{ft})^{2} \times 1440 \mathrm{~min} / d}$

$S=0.0008$

$K_{r}=T / b$

$K_{r}=\frac{4,100 f t^{2} / d}{74 f t}=60 f t / d$ 


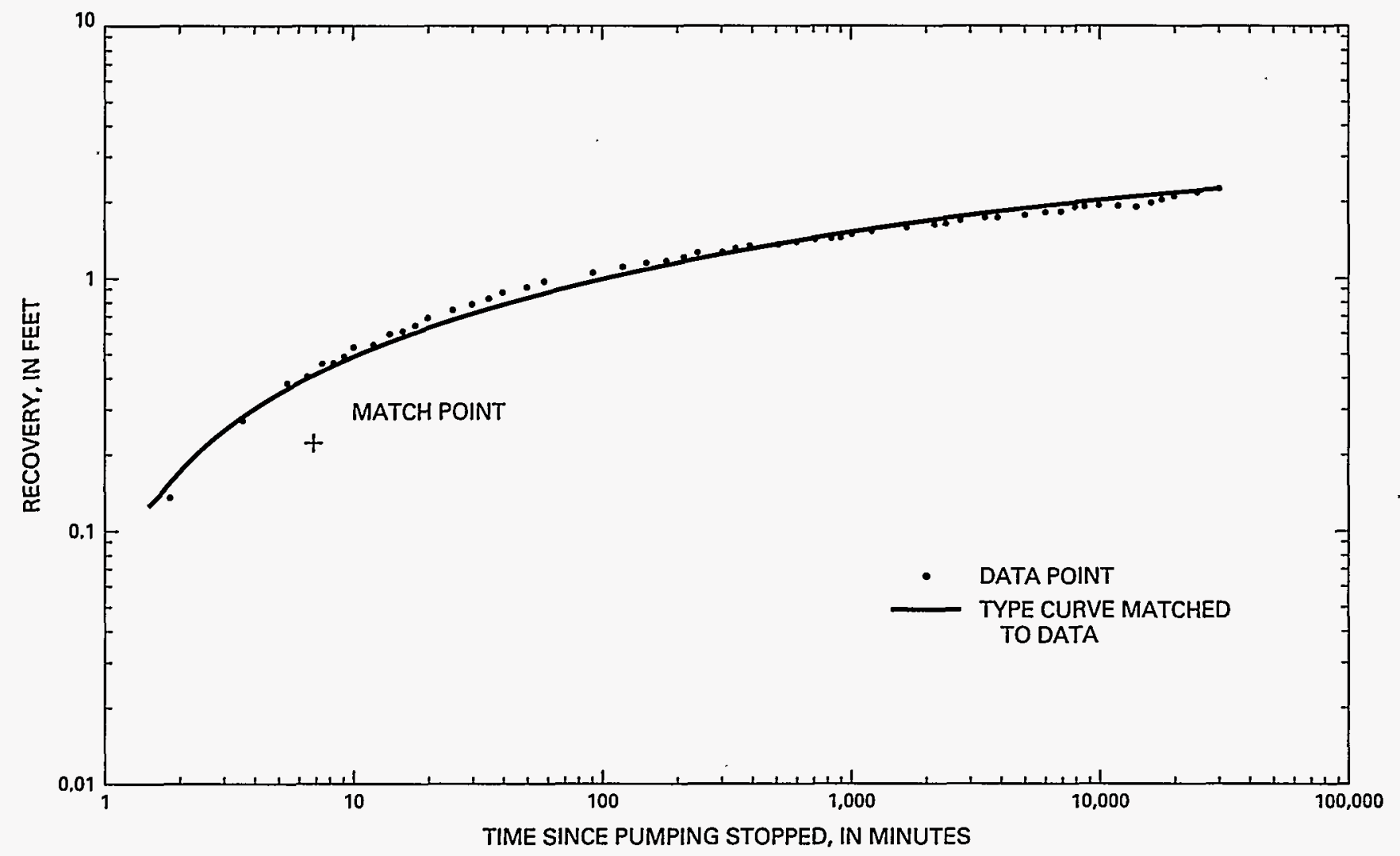

Figure 33. Analytical solution for recovery data from borehole UE-25c \#1 between the packers assuming an infinite, homogeneous, isotropic, confined aquifer, pumping test in borehole UE-25c \#3, October to December 1984.

Because of uncertainty regarding the estimate of flow contributed by rocks between the packers, calculated values of hydrologic properties presumably bracket the actual values.

Drawdown data obtained from borehole UE-25c \#1 below the packers reveal the influence of fault boundaries on the Tram aquifer. Drawdown below the packers became essentially constant after about 5,000 minutes of pumping, indicating a constant flux to the Tram aquifer from that point until pumping ceased. The two faults that are shown in figure 7 cutting the Tram aquifer at the c-hole complex probably are the source of the water recharged to the aquifer during pumping. As discussed previously, a constant flux from a fault is analogous to constant leakage from a confining unit without storage. Hence, the drawdown data from borehole UE-25c \#1 below the packers were matched to the type curve of Cooper (1963) for $v=0.02$ (fig. 35), and values of transmissivity (T), storativity $(S)$, and horizontal hydraulic conductivity $\left(K_{r}\right)$ were then calculated. Based on a heat-pulse flowmeter survey done in December 1991, it was estimated that
58 percent of the flow from rocks below casing and concrete in borehole UE-25c \#1 comes from the interval that was below the packers during this pumping test. The following calculations were made:

$$
\begin{gathered}
T=\frac{Q \times L(\mu v)}{4 \pi s}=\frac{\left(0.58 \times 425 \mathrm{gal} / \mathrm{min} \times 192.5 f t^{3} / d\right) \times 1}{(4 \pi \times 0.48 f \mathrm{ft}) \times 1 \mathrm{gal} / \mathrm{min}}=7,900 \mathrm{ft}^{2} / d \\
S=\frac{4 T t / r^{2}}{1 / \mu}=\frac{4 \times 7,900 \mathrm{ft}^{2} / \mathrm{d} \times 0.00012 \mathrm{~min} / \mathrm{ft}^{2}}{1 \times 1,440 \mathrm{~min} / \mathrm{d}}=0.003 \\
K_{r}=T / b=\frac{7,900 \mathrm{ft}^{2} / \mathrm{d}}{208 \mathrm{ft}}=40 \mathrm{ft} / \mathrm{d}
\end{gathered}
$$

As a check on the assumptions made regarding the percentage of flow contributed from rocks in borehole UE-25c \#1 above, between, and below the packers, values of transmissivity, storativity, and hydraulic conductivity obtained for each interval from the second pumping test in borehole UE-25c \#3 were added or averaged, as appropriate, and compared to composite values of hydrologic properties obtained from boreholes UE-25c \#2 and UE-25c \#3 during the first pump- 


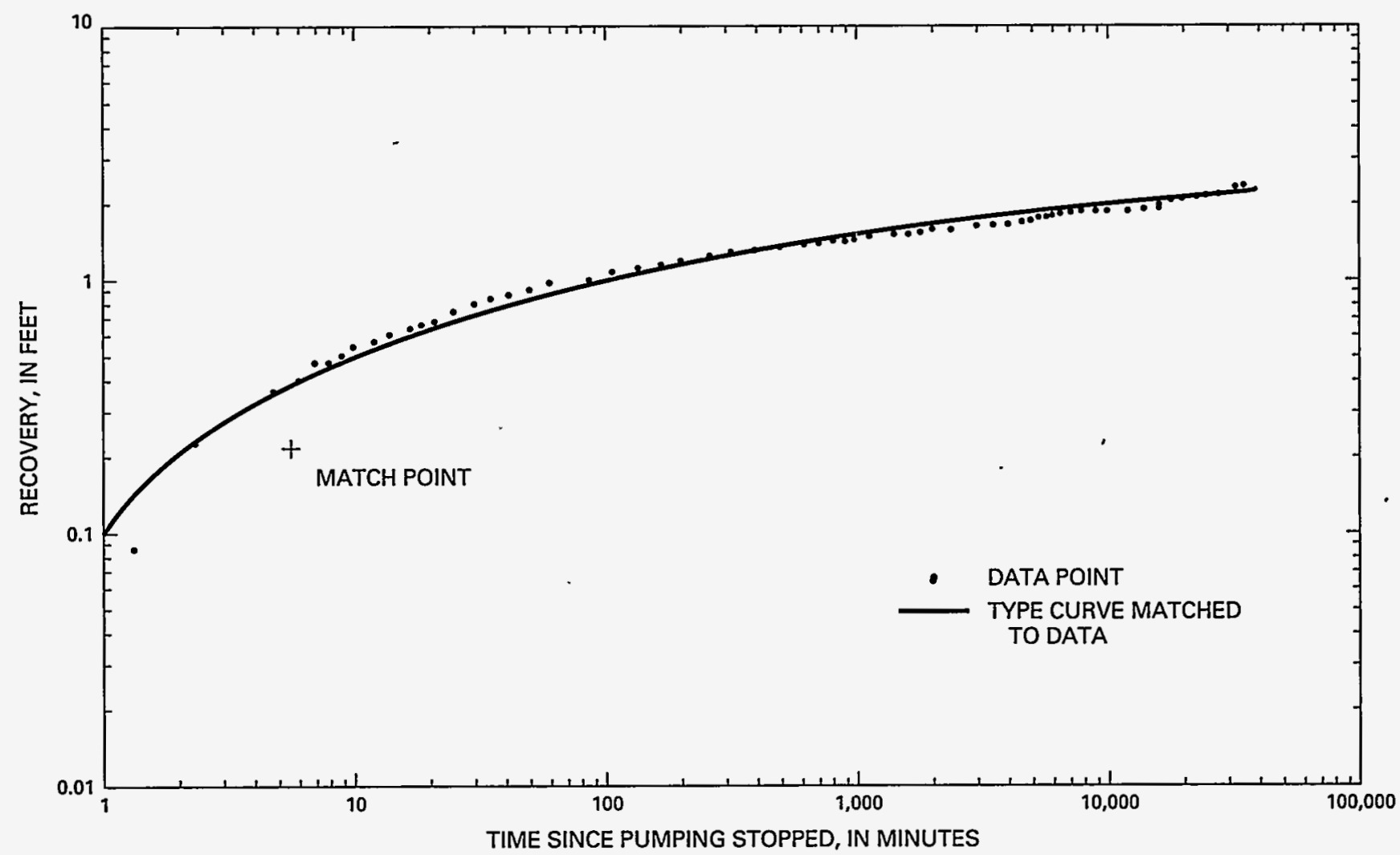

Figure 34. Analytical solution for recovery data from borehole UE-25c \#2 between the packers assuming an infinite, homogeneous, isotropic, confined aquifer, pumping test in borehole UE-25c \#3, October to December 1984.

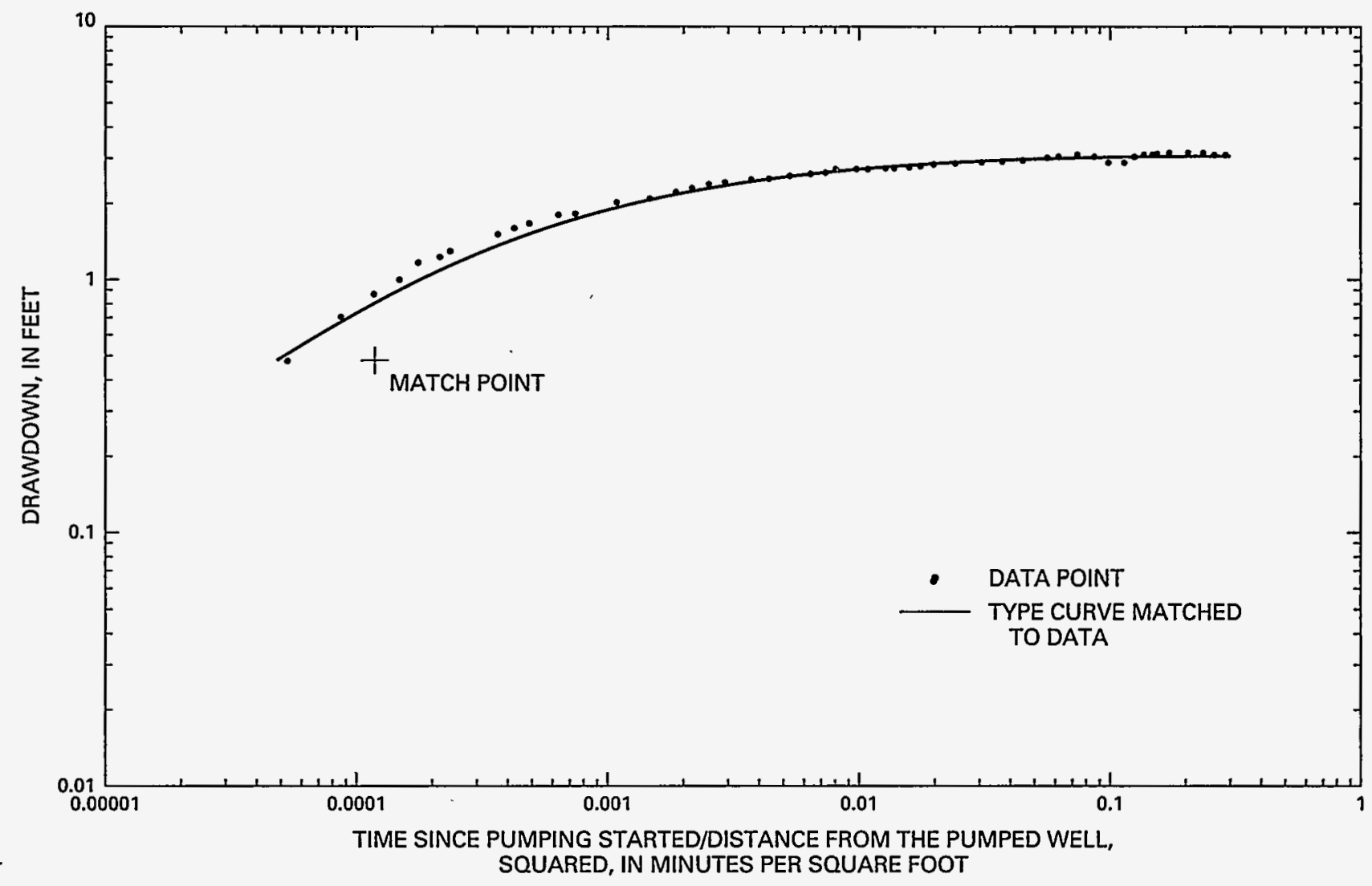

Figure 35. Analytical solution for drawdown data from borehole UE-25c \#1 below the packers assuming an infinite, homogeneous, isotropic, confined aquifer with leakage from a confining unit without storage, pumping test in borehole UE-25c $\# 3$, October to December 1984.

68 Results and Interpretation of Preliminary Aquifer Tests in Boreholes UE-25c \#1, UE-25c \#2, and UE-25c *3, Yucca Mountaln, Nye County, Nevada 
ing test in borehole UE-25c \#3 and the injection test in borehole UE-25c \#2. As indicated in table 9, composite values of transmissivity $=20,000 \mathrm{ft}^{2} / \mathrm{d}$, storativity = 0.004 , horizontal hydraulic conductivity $=30 \mathrm{ft} / \mathrm{d}$, and vertical hydraulic conductivity $=2 \mathrm{ft} / \mathrm{d}$ calculated for borehole UE-25c \#1 compare favorably with composite values of transmissivity, storativity, and hydraulic conductivity obtained for rocks in boreholes

UE-25c \#2 and UE-25c \#3. Therefore, calculations of hydrologic properties of the four aquifers penetrated by borehole UE-25c \#1 can be considered reasonable estimates.

\section{SUMMARY AND CONCLUSIONS}

Fluid-injection and pumping tests conducted in 1983 and 1984 in boreholes UE-25c \#1, UE-25c \#2, and UE-25c \#3 (the c-holes) on the east side of Yucca Mountain, Nev., were analyzed and interpreted in the context of other hydrogeologic information obtained from lithologic logs, borehole geophysical logs, core permeameter tests, and borehole flow surveys.

The c-holes, each of which is about $3,000 \mathrm{ft}$ deep, are 100 to $251 \mathrm{ft}$ apart at the surface. The three boreholes are completed in a 5,000-ft-thick sequence of Miocene tuffaceous rocks that is underlain by Paleozoic carbonate rocks and transected by highangle, north-northeasterly and northwesterly striking faults. The contact between the Miocene and Paleozoic rocks generally is believed to be a detachment fault, into which the north-northeasterly striking faults merge listrically. A pumping test conducted in borehole UE-25c \#2 indicated hydraulic connection between the Miocene and Paleozoic rocks, possibly through the network of faults cutting these rocks.

The depth to water at the c-hole complex ranges from 1,312 to $1,320 \mathrm{ft}$ below land surface. The c-holes are open in the saturated zone below an average depth of about $1,370 \mathrm{ft}$ from the land surface. Each of the c-holes is open in the tuffs and lavas of Calico Hills and the Prow Pass, Bullfrog, and Tram Members of the Crater Flat Tuff. These geologic units consist mostly of nonwelded to densely welded ash-flow tuff with interlayered ash-fall tuff and volcaniclastic rocks. A tuff breccia occurs in the Tram Member where the unit is transected by the Paintbrush Canyon Fault and another high-angle, north-northeasterly striking fault.

Tectonic and cooling fractures pervade the tuffaceous rocks penetrated by the c-holes, although fractures are distributed unevenly, and intervals range from unfractured to very fractured. Because of the fault brecciation, fracture frequency is greatest in the Tram Member. The bedded zone of the tuffs and lavas of Calico Hills, also, is very fractured. On the average, moderately to densely welded zones of the Prow Pass and Bullfrog Members are more fractured than bedded zones which, in turn, are more fractured than nonwelded to partially welded zones. Most fractures strike approximately south and dip westward at angles of $50^{\circ}-87^{\circ}$. The least common fractures strike generally east or west, and many of these are shallow-dipping or mineralized.

Within the saturated zone open to the c-holes, the tuffaceous rocks display layered heterogeneity. Permeameter tests indicate a vertical range in matrix permeability of 0.001 to $20 \mathrm{mD}$, with slightly larger permeability horizontally than vertically. Falling-head and pressure-injection tests in borehole UE-25c \#1 indicate a vertical range in hydraulic conductivity of 0.003 to $2 \mathrm{ft} / \mathrm{d}$. The average hydraulic conductivity in the horizontal direction in borehole UE-25c \#1 is $0.2 \mathrm{ft} / \mathrm{d}$, whereas the average hydraulic conductivity in the vertical direction is $0.02 \mathrm{ft} / \mathrm{d}$.

Fluid-injection tests and single-well pumping tests in boreholes UE-25c \#1 and UE-25c \#3 indicate a composite transmissivity of about $300 \mathrm{ft}^{2} / \mathrm{d}$ for the tuffs and lavas of Calico Hills and the Crater Flat Tuff. However, multiple-well, constant-flux tests in the c-holes indicate that single-well injection and withdrawal tests are not reliable indicators of site-scale hydrologic properties. For the entire thickness of rocks below casing and concrete in a borehole, cross-hole tests generally indicate values of transmissivity and hydraulic conductivity that are about two orders of magnitude larger than values obtained in single-well tests. This dependence of results on the radius of investigation can be interpreted as an effect of encompassing more conduits for ground-water flow, such as faults or fracture zones, as a larger volume of aquifer is investigated.

In the c-holes, eleven transmissive intervals were identified on the basis of fracture and matrix permeability distributions, borehole resistivity, temperature, and caliper logs, and heat-pulse flowmeter and tracejector surveys. The heat-pulse flowmeter surveys indicated downward flow in the upper parts and upward flow in the lower parts of boreholes UE-25c \#1 and UE-25c \#2, but upward flow through the entire surveyed section of borehole UE-25c \#3 (below a depth of about 1,500 $\mathrm{ft}$ ). The eleven transmissive intervals at the c-hole complex were grouped for purposes of investigation and discussion into four informal aquifers with intercalated confining units. In descending order, the four aquifers are the Calico Hills, Prow Pass-upper Bullfrog, Bullfrog, and Tram.

The Calico Hills aquifer is unconfined and anisotropic. The aquifer has a transmissivity of $100 \mathrm{ft}^{2} / \mathrm{d}$, a specific yield of 0.003 , a horizontal hydraulic conduc- 
Table 9. Summary of analyses of 1984 constant-flux aquifer tests in boreholes UE-25C \#1, UE-25C \#2, and UE-25c \#3

[Values of transmissivity rounded to two significant figures; other hydrologic properties rounded to one significant figure]

\begin{tabular}{|c|c|c|c|c|c|c|c|c|c|}
\hline \multirow{2}{*}{ Monltored Interval or borehole } & \multirow{2}{*}{$\begin{array}{c}\text { Transmlssivity } \\
\text { (feet squared } \\
\text { per day) }\end{array}$} & \multirow{2}{*}{ Storativity } & \multirow{2}{*}{$\begin{array}{c}\text { Fracture } \\
\text { storativity }\end{array}$} & \multirow{2}{*}{$\begin{array}{l}\text { Block } \\
\text { storativity }\end{array}$} & \multirow{2}{*}{$\begin{array}{l}\text { Specifflc } \\
\text { yleld }\end{array}$} & \multicolumn{4}{|c|}{ Hydraullc conductivity. (feet per day) } \\
\hline & & & & & & Horlzontal & Vertical & Fracture & Block \\
\hline \multicolumn{10}{|l|}{$\mathrm{UE}-25 \mathrm{c} \# 1$} \\
\hline Calico Hills aquifer & 100 . & & & & 0.003 & 0.5 & 1 & 7 & 0.01 \\
\hline Prow Pass-Upper Bullfrog aquifer & 3,300 & 0.0005 & & & 0.004 & 10 & 2 & & \\
\hline Bullfrog aquifer & 8,400 & .0002 & & & & 100 & 100 & & \\
\hline Tram aquifer & 7,900 & .003 & & & & 40 & 40 & & \\
\hline Composite & 20,000 & .004 & & & & 30 & 2 & & \\
\hline \multicolumn{10}{|l|}{ UE-25c \#2 } \\
\hline Composite (Neuman, 1975) & 23,000 & .004 & & & .07 & 40 & 5 & & \\
\hline Composite (Streltsova-Adams, 1978) & 29,000 & & .004 & .04 & & & & 50 & 0.01 \\
\hline \multicolumn{10}{|l|}{$\mathrm{UE}-25 \mathrm{c} \# 3$} \\
\hline Composite (Cooper-Jacob, 1946) & 35,000 & .002 & & & & 40 & & & \\
\hline
\end{tabular}


tivity of $0.5 \mathrm{ft} / \mathrm{d}$, and a vertical hydraulic conductivity of about $1 \mathrm{ft} / \mathrm{d}$.

The Prow Pass-upper Bullfrog aquifer may be either an unconfined, anisotropic aquifer or a fissureblock aquifer. If unconfined, the aquifer has an average transmissivity in pumping tests of $3,300 \mathrm{ft}^{2} / \mathrm{d}$, a specific yield of 0.004 , a storativity, combined with the Calico Hills aquifer, of 0.0005 , a horizontal hydraulic conductivity of $10 \mathrm{ft} / \mathrm{d}$, and a vertical hydraulic conductivity of $2 \mathrm{ft} / \mathrm{d}$.

The Bullfrog aquifer is confined, nonleaky, and isotropic. The aquifer has a transmissivity that in borehole UE-25c \#1 was determined to be $8,400 \mathrm{ft}^{2} / \mathrm{d}$ and in borehole UE-25c \#2 was determined to be $4,100 \mathrm{ft}^{2} / \mathrm{d}$. Assuming the larger value to be correct, the aquifer has a storativity of 0.0002 , and a hydraulic conductivity of $100 \mathrm{ft} / \mathrm{d}$.

The Tram aquifer, although confined, is recharged by leakage from faults. The aquifer has a transmissivity of $7,900 \mathrm{ft}^{2} / \mathrm{d}$, a storativity of 0.003 , and a hydraulic conductivity of $40 \mathrm{ft} / \mathrm{d}$.

Composite values of hydrologic properties determined for rocks in borehole UE-25c \#1 by adding or averaging interval values, as appropriate, compare favorably with composite values determined by monitoring borehole UE-25c \#2 during a pumping test in borehole UE-25 c\#3 and by monitoring borehole UE-25c \#3 during an injection test in borehole UE-25c \#2. For the entire thickness of rocks penetrated by the c-holes, transmissivity was determined to be between 20,000 and $35,000 \mathrm{ft}^{2} / \mathrm{d}$, storativity was determined to be between 0.002 and 0.004 , horizontal hydraulic conductivity was determined to be between 30 and $40 \mathrm{ft} / \mathrm{d}$, and vertical hydraulic conductivity was determined to be between 2 and $5 \mathrm{ft} / \mathrm{d}$.

\section{SELECTED REFERENCES}

Barker, J.A., and Black, J.H., 1983, Slug tests in fissured aquifers: American Geophysical Union, Water

- Resources Research, v. 19, no. 6, p. 1558-1564.

Bredehoeft, J.D., and Papadopulos, S.S., 1980, A method for determining the hydraulic properties of tight formations: American Geophysical Union, Water Resources Research, v. 16, no. 1, p. 233-238.

Carr, M.D., Waddell, S.J., Vick, G.S., Stock, J.M., Monsen, S.A., Harris, A.G., Cork, B.W., and Byers, F.M., Jr., 1986, Geology of drill hole UE-25p \#1: A test hole into pre-Tertiary rocks near Yucca Mountain, southern Nevada: U.S. Geological Survey Open-File Report 86-175, $87 \mathrm{p}$.

Carr, W.J., 1990, Styles of extension in the Nevada Test Site region, southern Walker Lane Belt; An integration of volcano-tectonic and detachment fault models, in
Wernicke, B.P., ed., Basin and Range extensional tectonics near the latitude of Las Vegas, Nevada: Boulder, Colo., Geological Society of America Memoir 176, p. 283-303.

Cooper, H.H., Jr., 1963, Type curves for nonsteady radial flow in an infinite leaky artesian aquifer, in Bentall, Ray, Compiler, Shortcuts and special problems in aquifer tests: U.S. Geological Survey Water-Supply Paper 1545-C, p. 48-55.

Cooper, H.H., Jr., and Jacob, C.E., 1946, A generalized graphical method for evaluating formation constants and summarizing well-field history: American Geophysical Union Transactions, v. 27, no. 4, p. 526-534.

Cooper, H.H., Jr., Bredehoeft, J.D., and Papadopulos, I.S., 1967, Response of a finite-diameter well to an instantaneous charge of water: American Geophysical Union, Water Resources Research, v. 3, no. 1, p. 263-269.

Driscoll, F.G., 1986, Groundwater and wells: St. Paul, Minnesota, Johnson Division, 1089 p.

Fenix and Scisson, Inc., 1986, NNWSI hole histories UE-25c \#1, UE-25c \#2, UE-25c \#3: Tulsa, Okla., 60 p.

Freeze, R.A., and Cherry, J.A., 1979, Groundwater: Englewood Cliffs, N.J., Prentice-Hall, Inc., 604 p.

Frizzell, V.A., Jr., and Shulters, Jacqueline, 1990, Geologic map of the Nevada Test Site, southern Nevada: U.S. Geological Survey Miscellaneous Investigations Map I-2046, scale 1:100,000.

Galloway, D.L., and Rojstaczer, Stuart, 1988, Analysis of the frequency response of water levels in wells to Earth tides and atmospheric loading, in Hitchon, Brian, and Bachü, Stefan, eds., Proceedings Fourth Canadian/ American Conference on Hydrogeology - Fluid flow, heat transfer, and mass transport in fractured rocks: Dublin, Ohio, National Water Well Association, p. 100-113.

Geldon, A.L., 1993, Preliminary hydrogeologic assessment of boreholes UE-25c \#1, UE-25c \#2, and UE-25c \#3, Yucca Mountain, Nye County, Nevada: U.S. Geological Survey Water-Resources Investigations Report 92-4016, 85 p.

Gringarten, A.C., 1982, Flow-test evaluation of fractured reservoirs, in Narasimhan, T.N., ed., Recent trends in hydrogeology: Boulder, Colo., Geological Society of America Special Paper 189, p. 237-263.

Hess, A.E., 1990, Thermal-pulse flowmeter for measuring slow velocities in boreholes: U.S. Geological Survey Open-File Report 87-121, 70 p.

Lobmeyer, D.H., Whitfield, M.S., Lahoud, R.R., and Bruckheimer, Laura, 1983, Geohydrologic data for test well UE-25b \#1, Nevada Test Site, Nye County, Nevada: U.S. Geological Survey Open-File Report 83-855, 48 p.

Lohman, S.W., 1979, Ground-water hydraulics: U.S. Geological Survey Professional Paper 708, 70 p. 
Nelson, P.H., Muller, D.C., Schimschal, Ulrich, and Kibler, J.E., 1991, Geophysical logs and core measurements from forty boreholes at Yucca Mountain, Nevada: U.S. Geological Survey Geophysical Investigations Map GP-1001.

Neuman, Shlomo, 1975, Analysis of pumping test data from anisotropic unconfined aquifers considering delayed gravity response: American Geophysical Union, Water Resources Research, v. 11, no. 2, p. 329-342.

Neuzil, C.E., 1982, On conducting the modified "slug" test in tight formations: American Geophysical Union, Water Resources Research, v. 18, no. 2, p. 439-441.

Reed, J.E., 1980, Type curves for selected problems of flow to wells in confined aquifers: U.S. Geological Survey Techniques of Water-Resources Investigations, book 3, chap. B3.

Robison, J.H., and Craig, R.W., 1991, Geohydrology of rocks penetrated by test well USW H-5, Yucca Mountain, Nye County, Nevada: U.S. Geological Survey Water-Resources Investigations Report 88-4168, 44 p.

Robison, J.H., Stephens, D.M., Luckey, R.R., and Baldwin, D.A., 1988, Water levels in periodically measured wells in the Yucca Mountain area, Nevada, 1981-87: U.S. Geological Survey Open-File Report 88-468, 132 p.
Rush, F.E., Thordarson, William, and Bruckheimer, Laura, 1983, Geohydrologic and drill-hole data for test well USW H-1, adjacent to Nevada Test Site, Nye County, Nevada: U.S. Geological Survey Open-File Report 83-141, 38 p.

Scott, R.B., 1990, Tectonic setting of Yucca Mountain, southwest Nevada in Wernicke, B.P., ed., Basin and Range extensional tectonics near the latitude of Las Vegas, Nevada: Boulder, Colo., Geological Society of America Memoir 176, p. 251-282.

Scott, R.B., and Bonk, Jerry, 1984, Preliminary geologic map of Yucca Mountain, Nye County, Nevada, with geologic sections: U.S. Geological Survey Open-File Report 84-494, scale 1:12,000.

Streltsova-Adams, T.D., 1978, Well testing in heterogeneous aquifer formations, in Chow, V.T., ed., Advances in hydroscience: New York, Academic Press, v. 11, p. $357-423$.

Theis, C.V., 1935, The relation between the lowering of the piezometric surface and the rate and duration of discharge of a well using ground-water storage: American Geophysical Union Transactions, v. 16, p. 519-524. 


\section{SUPPLEMENTAL DATA}


TABLE 10. SUMMARY OF INFORMATION FROM LITHOLOGIC (L), TELEVISION (TV), ACOUSTIC TELEVIEWER (AT), CALIPER (C), AND TEMPERATURE (TEMP) LOGS FOR BOREHOLE UE-25C \#1

[Abbreviations for tables 10,11, and 12: SG, casing; NW, nonwelded; NW-PW, nonwelded to partially welded; MW, moderately welded; MW-DW, moderately to densely welded; PW-NW, partially welded to nonwelded; PW, partially welded; N.VERT, near vertical; LITH, lithologic; TD, total depth; N, north, S, south; SW, southwest, SE, southeast; SSW, south-southwest]

\begin{tabular}{|c|c|c|c|c|c|c|c|c|c|}
\hline \multicolumn{2}{|c|}{$\begin{array}{c}\text { DEPTH BLW } \\
\text { CASING } \\
\text { (FEET) }\end{array}$} & \multirow[t]{2}{*}{ GEOLÖGIC UNIT } & \multirow{2}{*}{$\begin{array}{l}\text { LITHOLOGIC } \\
\text { ZONE }\end{array}$} & \multirow[t]{2}{*}{ FEATURE } & \multirow{2}{*}{$\begin{array}{l}\text { DIP } \\
\text { AZI- } \\
\text { MUTH }\end{array}$} & \multirow[t]{2}{*}{ DIP ANGLE } & \multirow{2}{*}{$\begin{array}{c}\text { STRIKE } \\
\text { AZI- } \\
\text { MUTH }\end{array}$} & \multirow[t]{2}{*}{ REMARKS } & \multirow[t]{2}{*}{ LOG } \\
\hline TOP & $\begin{array}{l}\text { BOT- } \\
\text { TOM }\end{array}$ & & & & & & & & \\
\hline 1313 & & TOPOPAH SPRING & BASAL & WATER TABLE & & & & $\begin{array}{l}\text { ABRUPT INCREASE IN TEMPERA- } \\
\text { TURE }\end{array}$ & TEMP \\
\hline 1332 & & CALICO HIILS & NW & CONTACT & & & . & & $\mathbf{L}$ \\
\hline 1362 & & & & BOTTOM OF CSG & & & & $\begin{array}{l}\text { TEXTURE CHANGE FROM } \\
\text { SMOOTH TO ROUGH BLW CSG }\end{array}$ & TV \\
\hline 1362 & 1371 & & & CONCRETE & & & & $\begin{array}{l}\text { ABRUPT INCREASE IN DIAMETER } \\
\text { BELOW CONCRETE }\end{array}$ & TV/C \\
\hline 1427 & 1428 & & & FRACTURE & 265 & N. VERT & 175 & $\begin{array}{l}\text { HOLE SKEWED AND VISIBILITY } \\
\text { POOR } 1371-1505\end{array}$ & TV \\
\hline 1461 & 1461 & & & FRACTURE & 225 & SHALLOW & 135 & & TV \\
\hline 1486 & 1486 & & & FRACTURE & 280 & N. VERT & 190 & & TV \\
\hline 1486 & 1487 & & & FRACTURE & 225 & SHALLOW & 135 & & TV \\
\hline 1505 & 1506 & & & FRACTURE & 20 & STEEP & 290 & & TV \\
\hline 1506 & 1506 & & & FRACTURE & 30 & STEEP & 300 & . & TV \\
\hline 1510 & 1511 & & & LEDGE & & & & HOLE DLAMETER REDUCED & TV \\
\hline 1515 & 1516 & & & FRACTURE & 95 & STEEP & 5 & & TV \\
\hline 1521 & 1523 & & & FRACTURE & 180 & STEEP & 90 & & TV \\
\hline 1522 & 1524 & & & FRACTURE & 210 & STEEP & 120 & & TV \\
\hline 1523 & 1525 & & & FRACTURE & 95 & STEEP & 5 & & TV \\
\hline 1523 & 1534 & & & FRACTURE & 275 & VERTICAL & 185 & $\begin{array}{l}\text { SPLAYS WITH INTERSTITIAL } \\
\text { CAVITIES }\end{array}$ & TV \\
\hline 1525 & 1528 & & & FRACTURE & 95 & N. VERT & 5 & & TV \\
\hline 1530 & 1534 & & & FRACTURE & 105 & N. VERT & 15 & & TV \\
\hline 1530 & 1531 & & & FRACTURE & 270 & STEEP & 180 & & TV \\
\hline 1531 & 1532 & & & FRACTURE & 260 & STEEP & 170 & & TV \\
\hline 1532 & 1532 & & & FRACTURE & 260 & STEEP & 170 & & TV \\
\hline 1535 & 1541 & & & FRACTURE & 350 & VERTICAL & 260 & & TV \\
\hline 1535 & 1535 & & & FRACTURE & 145 & STEEP & 55 & & TV \\
\hline 1541 & 1544 & & & FRACTURE & 270 & N. VERT & 180 & & TV \\
\hline 1561 & 1562 & & & FRACTURE & 255 & SHALLOW & 165 & & TV \\
\hline 1582 & 1584 & & & FRACTURE & 170 & STEEP & 80 & & TV \\
\hline
\end{tabular}


TABLE 10. SUMMARY OF INFORMATION FROM LITHOLOGIC (L), TELEVISION (TV), ACOUSTIC TELEVIEWER (AT), CALIPER (C), AND TEMPERATURE (TEMP) LOGS FOR BOREHOLE UE-25C \#1 -Continued

\begin{tabular}{|c|c|c|c|c|c|c|c|c|c|}
\hline \multicolumn{2}{|c|}{$\begin{array}{l}\text { DEPTH BLW } \\
\text { CASING } \\
\text { (FEET) }\end{array}$} & \multirow[t]{2}{*}{ GEOLOGIC UNIT } & \multirow{2}{*}{$\begin{array}{l}\text { LTTHOLOGIC } \\
\text { ZONE }\end{array}$} & \multirow[t]{2}{*}{ FEATURE } & \multirow{2}{*}{$\begin{array}{c}\text { DIP } \\
\text { AZI } \\
\text { MUTH }\end{array}$} & \multirow[t]{2}{*}{ DIP ANGLE } & \multirow{2}{*}{$\begin{array}{c}\text { STRIKE } \\
\text { AZI- } \\
\text { MUTH }\end{array}$} & \multirow[t]{2}{*}{ REMARKS } & \multirow[t]{2}{*}{ LOG } \\
\hline TOP & $\begin{array}{l}\text { BOT- } \\
\text { TOM }\end{array}$ & & & & & & & & \\
\hline 1593 & & & BEDDED & CONTACT & & & & $\begin{array}{l}\text { TEXTURE ROUGHER AND VISIBIL } \\
\text { ITY POORER }\end{array}$ & $\mathrm{L}$ \\
\hline 1636 & 1637 & & & FRACTURE & 180 & SHALLOW & 90 & & TV \\
\hline 1638 & 1639 & & & FRACTURE & 285 & N. VERT & 195 & & TV \\
\hline 1672 & 1673 & & & FRACTURE & 170 & N. VERT & 90 & & TV \\
\hline 1691 & 1692 & PROW PASS & NW-PW & CONTACT & & & & OPEN PARTING & TV/L \\
\hline 1693 & 1694 & & & FRACTURE & 117 & 27 & $\cdot 27$ & & $\mathrm{AT}$ \\
\hline 1791 & 1791 & & & FRACTURE & 210 & SHALLOW & 120 & & TV \\
\hline 1802 & 1802 & & & FRACTURE & 230 & SHALLOW & 140 & MINERALIZED & TV \\
\hline 1803 & 1804 & & & FRACTURE & 315 & SHALLOW & 225 & & TV \\
\hline 1805 & 1806 & & & FRACTURE & 230 & N. VERT & 140 & & TV \\
\hline 1806 & 1806 & & & FRACTURE & 125 & SHALLOW & 35 & & TV \\
\hline 1806 & 1807 & & & FRACTURE & 230 & STEEP & 140 & & TV \\
\hline 1806 & 1808 & & & FRACTURE & 245 & STEEP & 155 & & $\mathrm{TV}$ \\
\hline 1808 & 1809 & & & FRACTURE & 190 & N. VERT & 100 & & TV \\
\hline 1809 & 1810 & & & FRACTURE & 250 & N. VERT & 160 & & TV \\
\hline 1809 & 1813 & & & FRACTURE & 298 & 76 & 208 & . & $\mathrm{AT}$ \\
\hline 1811 & 1817 & & & FRACTURE & 300 & VERTICAL & 210 & & TV \\
\hline 1815 & 1821 & & & FRACTURE & 215 & VERTICAL & 125 & & $\mathrm{TV}$ \\
\hline
\end{tabular}


\% TABLE 10. SUMMARY OF INFORMATION FROM LITHOLOGIC (L), TELEVISION (TV), ACOUSTIC TELEVIEWER (AT), CALIPER (C), AND TEMPERATURE (TEMP) LOGS FOR BOREHOLE UE-25C \#1 --Continued

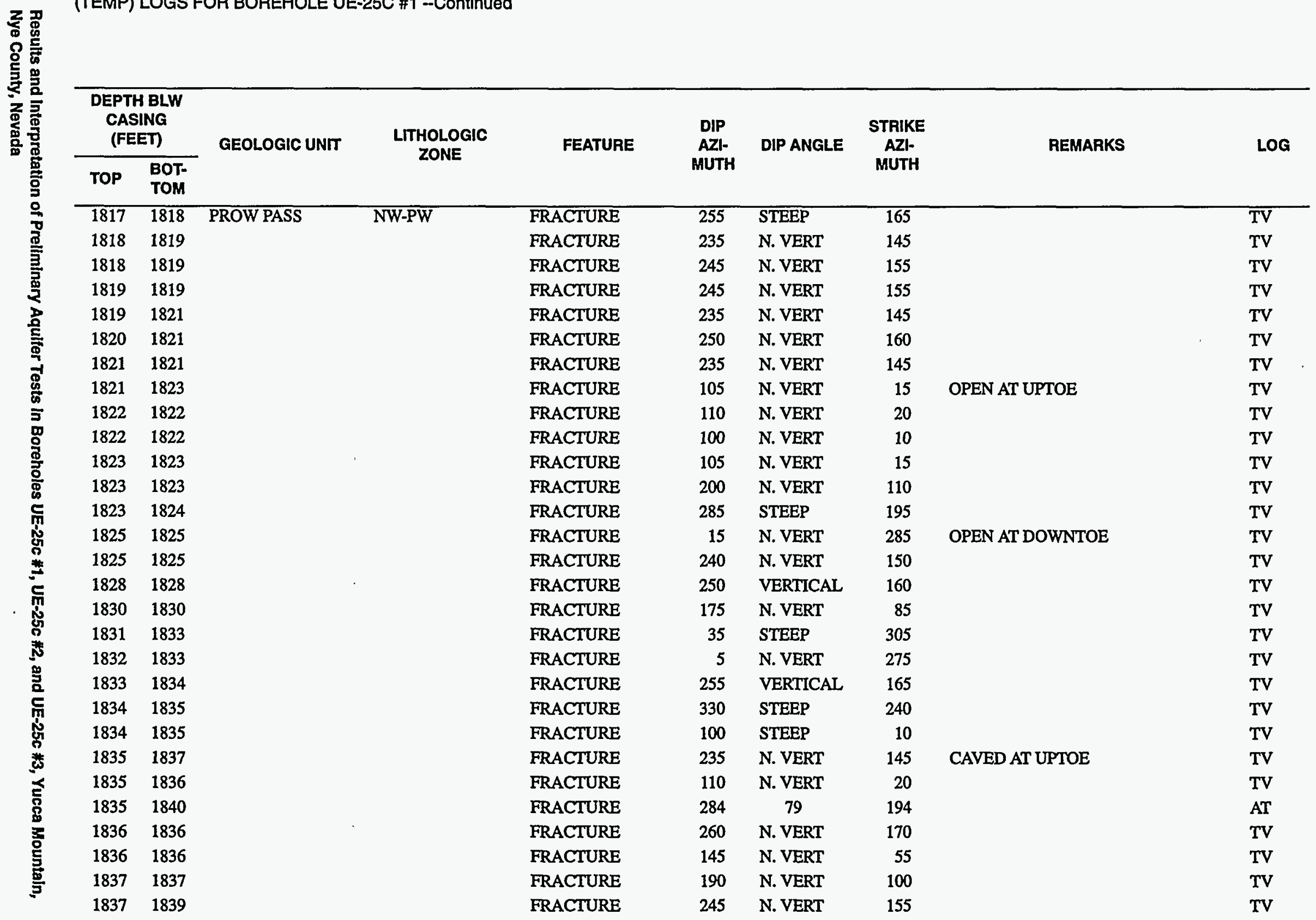


TABLE 10. SUMMARY OF INFORMATION FROM LITHOLOGIC (L), TELEVISION (TV), ACOUSTIC TELEVIEWER (AT), CALIPER (C), AND TEMPERATURE (TEMP) LOGS FOR BOREHOLE UE-25C \#1 -Continued

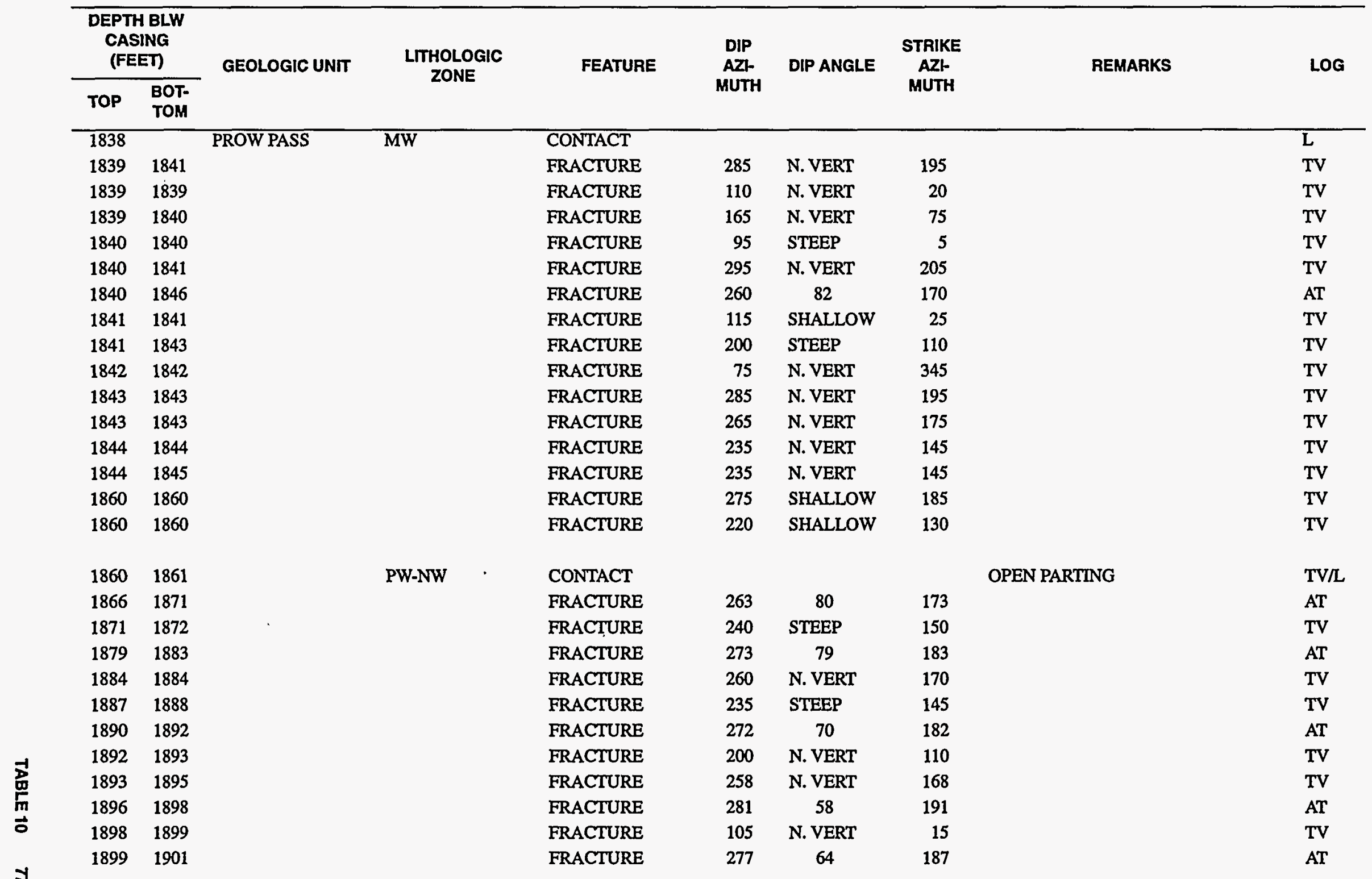


TABLE 10. SUMMARY OF INFORMATION FROM LITHOLOGIC (L), TELEVISION (TV), ACOUSTIC TELEVIEWER (AT), CALIPER (C), AND TEMPERATURE (TEMP) LOGS FOR BOREHOLE UE-25C \#1 -Continued

\begin{tabular}{|c|c|c|c|c|c|c|c|c|c|}
\hline \multicolumn{2}{|c|}{$\begin{array}{l}\text { DEPTH BLW } \\
\text { CASING } \\
\text { (FEET) }\end{array}$} & \multirow[t]{2}{*}{ GEOLOGIC UNIT } & \multirow{2}{*}{$\begin{array}{l}\text { LITHOLOGIC } \\
\text { ZONE }\end{array}$} & \multirow[t]{2}{*}{ FEATURE } & \multirow{2}{*}{$\begin{array}{c}\text { DIP } \\
\text { AZI- } \\
\text { MUTH }\end{array}$} & \multirow[t]{2}{*}{ DIP ANGLE } & \multirow{2}{*}{$\begin{array}{c}\text { STRIKE } \\
\text { AZI- } \\
\text { MUTH }\end{array}$} & \multirow[t]{2}{*}{ REMARKS } & \multirow[t]{2}{*}{ LOG } \\
\hline TOP & $\begin{array}{l}\text { BOT- } \\
\text { TOM }\end{array}$ & & & & & & & & \\
\hline 1902 & 1903 & PROW PASS & PW-NW & FRACTURE & 295 & STEEP & 205 & MANY SPLAYS & $\overline{T V}$ \\
\hline 1907 & 1909 & & & FRACTURE & 262 & STEEP & 172 & & TV \\
\hline 1910 & 1910 & & & FRACTURE & 195 & SHALLOW & 105 & & TV \\
\hline 1911 & 1913 & & & FRACTURE & 260 & STEEP & 170 & & TV \\
\hline 1919 & 1922 & & & FRACTURE & 275 & STEEP & 185 & BOTH TOES OPEN (CAVED) & TV \\
\hline 1920 & 1921 & & & FRACTURE & $180^{\circ}$ & STEEP & 90 & OPEN AT UPTOE & TV \\
\hline 1921 & 1922 & & & FRACTURE & 105 & SHALLOW & 15 & & TV \\
\hline 1924 & 1925 & & $\cdot$ & FRACTURE & 105 & SHALLOW & 15 & & TV \\
\hline 1939 & 1942 & & & FRACTURE & 275 & N. VERT & 185 & & TV \\
\hline 1940 & 1941 & & & FRACTURE & 280 & STEEP & 190 & OPEN & TV \\
\hline 1942 & 1948 & & & FRACTURE & 280 & VERTICAL & 190 & & TV \\
\hline 1943 & 1945 & & & FRACTURE & 290 & 63 & 200 & & AT \\
\hline 1947 & 1950 & & & FRACTURE & 322 & 74 & 232 & & AT \\
\hline 1963 & 1964 & & & FRACTURE & 105 & 28 & 15 & OPEN & $\mathrm{AT}$ \\
\hline 1974 & 1975 & · & & FRACTURE & 110 & 44 & 20 & OPEN & AT \\
\hline 1982 & 1985 & & & FRACTURE & 273 & 73 & 183 & & $\mathrm{AT}$ \\
\hline 2071 & 2071 & & & FRACTURE & 265 & SHALLOW & 175 & $\begin{array}{l}\text { VISIBILITY POOR 2061-2118 } \\
\text { BECAUSE OF SKEWED HOLE }\end{array}$ & TV \\
\hline 2079 & 2079 & & & FRACTURE & 180 & VERTICAL & 90 & & TV \\
\hline 2081 & 2081 & & & FRACTURE & 215 & VERTICAL & 125 & & TV \\
\hline 2087 & 2087 & & & FRACTURE & 145 & VERTICAL & 55 & . & TV \\
\hline 2114 & 2115 & , & & FRACTURE & 25 & N. VERT & 295 & &.$T V$ \\
\hline 2115 & 2118 & & & FRACTURE & 285 & VERTICAL & 195 & OPEN & TV \\
\hline 2118 & & & BEDDED & CONTACT & & & & $\begin{array}{l}\text { SMOOTHER TEXTURE, CORRUGA- } \\
\text { TIONS AT CONTACT }\end{array}$ & TV/L \\
\hline 2118 & 2119 & & & FRACTURE & 270 & N. VERT & 180 & & TV \\
\hline 2119 & 2119 & & & FRACTURE & 235 & N. VERT & 145 & & TV \\
\hline 2121 & 2122 & & & FRACTURE & 272 & 30 & 182 & & $\mathrm{AT}$ \\
\hline 2122 & 2122 & & & FRACTURE & 260 & 22 & 170 & & $\mathrm{AT}$ \\
\hline 2124 & 2124 & & & FRACTURE & 280 & SHALLOW & 190 & & TV \\
\hline
\end{tabular}


TABLE 10. SUMMARY OF INFORMATION FROM LITHOLOGIC (L), TELEVISION (TV), ACOUSTIC TELEVIEWER (AT), CALIPER (C), AND TEMPERATURE (TEMP) LOGS FOR BOREHOLE UE-25C \#1 -Continued

\begin{tabular}{|c|c|c|c|c|c|c|c|c|c|}
\hline \multicolumn{2}{|c|}{$\begin{array}{l}\text { DEPTH BLW } \\
\text { CASING } \\
\text { (FEET) }\end{array}$} & \multirow[t]{2}{*}{ GEOLOGIC UNIT } & \multirow{2}{*}{$\begin{array}{l}\text { LITHOLOGIC } \\
\text { ZONE }\end{array}$} & \multirow{2}{*}{ FEATURE } & \multirow{2}{*}{$\begin{array}{c}\text { DIP } \\
\text { AZI- } \\
\text { MUTH }\end{array}$} & \multirow{2}{*}{ DIP ANGLE } & \multirow{2}{*}{$\begin{array}{c}\text { STRIKE } \\
\text { AZI- } \\
\text { MUTH }\end{array}$} & \multirow{2}{*}{ REMARKS } & \multirow[t]{2}{*}{ LOG } \\
\hline TOP & $\begin{array}{l}\text { BOT- } \\
\text { TOM }\end{array}$ & & & & & & & & \\
\hline 2127 & 2129 & \multirow{7}{*}{ PROW PASS } & \multirow{7}{*}{ BEDDED } & FRACTURE & 274 & 58 & 184 & & $\mathrm{AT}$ \\
\hline 2130 & 2131 & & & FRACTURE & 265 & 42 & 175 & & AT \\
\hline 2130 & 2131 & & & FRACTURE & 35 & VERTICAL & 305 & & TV \\
\hline 2146 & 2147 & & & FRACTURE & 259 & 30 & 169 & & AT \\
\hline 2150 & 2150 & & & FRACTURE & 120 & SHALLOW & 30 & & TV \\
\hline 2151 & 2152 & & & FRACTURE & 160 & SHALLOW & 70 & & TV \\
\hline 2152 & 2152 & & & FRACTURE & 120 & VERTICAL & 30 & & TV \\
\hline 2152 & 2153 & \multirow[t]{14}{*}{ BULLFROG } & \multirow[t]{14}{*}{ NW-PW } & CONTACT & & & & OPEN PARTING & TV/L \\
\hline 2204 & 2204 & & & FRACTURE & 320 & SHALLOW & 230 & & TV \\
\hline 2204 & 2204 & & & FRACTURE & 95 & SHALLOW & 5 & & TV \\
\hline 2206 & 2206 & & & FRACTURE & . $285^{\circ}$ & N. VERT & 195 & & TV \\
\hline 2209 & 2209 & & & FRACTURE & 220 & SHALLOW & 130 & & TV \\
\hline 2209 & 2210 & & & FRACTURE & 225 & SHALLOW & 135 & & TV \\
\hline 2215 & 2215 & & & FRACTURE & 110 & N. VERT & 20 & & TV \\
\hline 2216 & 2216 & & & FRACTURE & 265 & SHALLOW & 175 & & TV \\
\hline 2216 & 2218 & & & FRACTURE & 220 & N. VERT & 130 & OPEN & TV \\
\hline 2217 & 2222 & & & FRACTURE & 283 & 78 & 193 & & $\mathrm{AT}$ \\
\hline 2219 & 2220 & & & FRACTURE & 260 & VERTICAL & 170 & & TV \\
\hline 2230 & 2230 & & & FRACTURE & 220 & N. VERT & 130 & & TV \\
\hline 2234 & 2234 & & & FRACTURE & 90 & VERTICAL & 0 & & TV \\
\hline 2238 & 2238 & & & FRACTURE & 240 & N. VERT & 150 & OPEN UPTOE & TV \\
\hline
\end{tabular}


\& TABLE 10. SUMMARY OF INFORMATION FROM LITHOLOGIC (L), TELEVISION (TV), ACOUSTIC TELEVIEWER (AT), CALIPER (C), AND TEMPERATURE .

(TEMP) LOGS FOR BOREHOLE UE-25C \#1 --Continued

\begin{tabular}{|c|c|c|c|c|c|c|c|c|c|}
\hline \multicolumn{2}{|c|}{$\begin{array}{l}\text { DEPTH BLW } \\
\text { CASING } \\
\text { (FEET) }\end{array}$} & \multirow[t]{2}{*}{ GEOLOGIC UNIT } & \multirow{2}{*}{$\begin{array}{l}\text { LITHOLOGIC } \\
\text { ZONE }\end{array}$} & \multirow[t]{2}{*}{ FEATURE } & \multirow{2}{*}{$\begin{array}{c}\text { DIP } \\
\text { AZI- } \\
\text { MUTH }\end{array}$} & \multirow[t]{2}{*}{ DIP ANGLE } & \multirow{2}{*}{$\begin{array}{c}\text { STRIKE } \\
\text { AZI- } \\
\text { MUTH }\end{array}$} & \multirow[t]{2}{*}{ REMARKS } & \multirow[t]{2}{*}{ LOG } \\
\hline TOP & $\begin{array}{l}\text { BOT- } \\
\text { TOM }\end{array}$ & & & & & & & & \\
\hline 2239 & 2240 & BULLFROG & NW-PW & FRACTURE & 210 & N.VERT & 120 & & TV \\
\hline 2241 & 2241 & & & FRACTURE & 240 & N. VERT & 150 & & TV \\
\hline 2241 & 2243 & & & FRACTURE & 267 & 67 & 177 & & $\mathrm{AT}$ \\
\hline 2260 & & BULLFROG & MW-DW & CONTACT & & & & & L \\
\hline 2270 & 2274 & & & FRACTURE & 235 & N. VERT & 145 & MINERALIZED & TV \\
\hline 2281 & 2281 & & & FRACTURE & 265 & N. VERT & 175 & MINERALIZED & TV \\
\hline 2301 & 2304 & & & FRACTURE & 250 & N. VERT & 160 & MINERALIZED & TV \\
\hline 2311 & 2314 & & & FRACTURE & 280 & N. VERT & 190 & MINERALIZED & TV \\
\hline 2312 & 2313 & & & FRACTURE & 55 & N. VERT & 325 & MINERALIZED & TV \\
\hline 2315 & 2318 & & & FRACTURE & 10 & N. VERT & 280 & & TV \\
\hline 2318 & 2318 & & & FRACTURE & 245 & N. VERT & 155 & MINERALIZED & TV \\
\hline 2320 & 2326 & & & FRACTURE & 190 & VERTICAL & 100 & & TV \\
\hline 2327 & 2328 & & & FRACTURE & 10 & STEEP & 280 & & TV \\
\hline 2332 & 2333 & & & FRACTURE & 270 & N. VERT & 180 & & TV \\
\hline 2342 & 2344 & & & FRACTURE & 190 & N. VERT & 100 & MINERALIZED & TV \\
\hline 2352 & 2358 & & & FRACTURE & 265 & VERTICAL & 175 & MINERALIZED & TV \\
\hline 2362 & 2364 & & & FRACTURE & 260 & N. VERT & 170 & MINERALIZED & TV \\
\hline 2363 & 2363 & & & FRACTURE & 270 & N. VERT & 180 & & TV \\
\hline 2365 & 2370 & & & FRACTURE & 255 & VERTICAL & 165 & MINERALIZED & TV \\
\hline 2366 & 2366 & & & FRACTURE & 225 & N. VERT & 135 & MINERALIZED & TV \\
\hline 2368 & 2370 & & & FRACTURE & 230 & N. VERT & 140 & MINERALIZED & TV \\
\hline 2378 & 2381 & & & FRACTURE & 205 & N. VERT & 115 & MINERALIZED & TV \\
\hline 2385 & 2385 & & & FRACTURE & 260 & N. VERT & 170 & MINERALIZED & TV \\
\hline 2387 & 2388 & & & FRACTURE & 245 & N. VERT & 155 & MINERALIZED & TV \\
\hline 2390 . & 2391 & & & FRACTURE & 250 & N. VERT & 160 & MINERALIZED & TV \\
\hline 2392 & 2397 & & & FRACTURE & 190 & VERTICAL & 100 & PARTLY MINERALIZED & TV \\
\hline 2407 & 2411 & & & FRACTURE & 255 & N. VERT & 165 & MINERALIZED & TV \\
\hline 2424 & 2427 & & & FRACTURE & 267 & 67 & 177 & MINERALIZED & AT \\
\hline 2432 & 2436 & & & FRACTURE & 275 & N. VERT & 185 & & TV \\
\hline 2436 & 2439 & & & FRACTURE & 285 & VERTICAL & 195 & MINERALIZED & TV \\
\hline
\end{tabular}


TABLE 10. SUMMARY OF INFORMATION FROM LITHOLOGIC (L), TELEVISION (TV), ACOUSTIC TELEVIEWER (AT), CALIPER (C), AND TEMPERATURE (TEMP) LOGS FOR BOREHOLE UE-25C \#1 --Continued

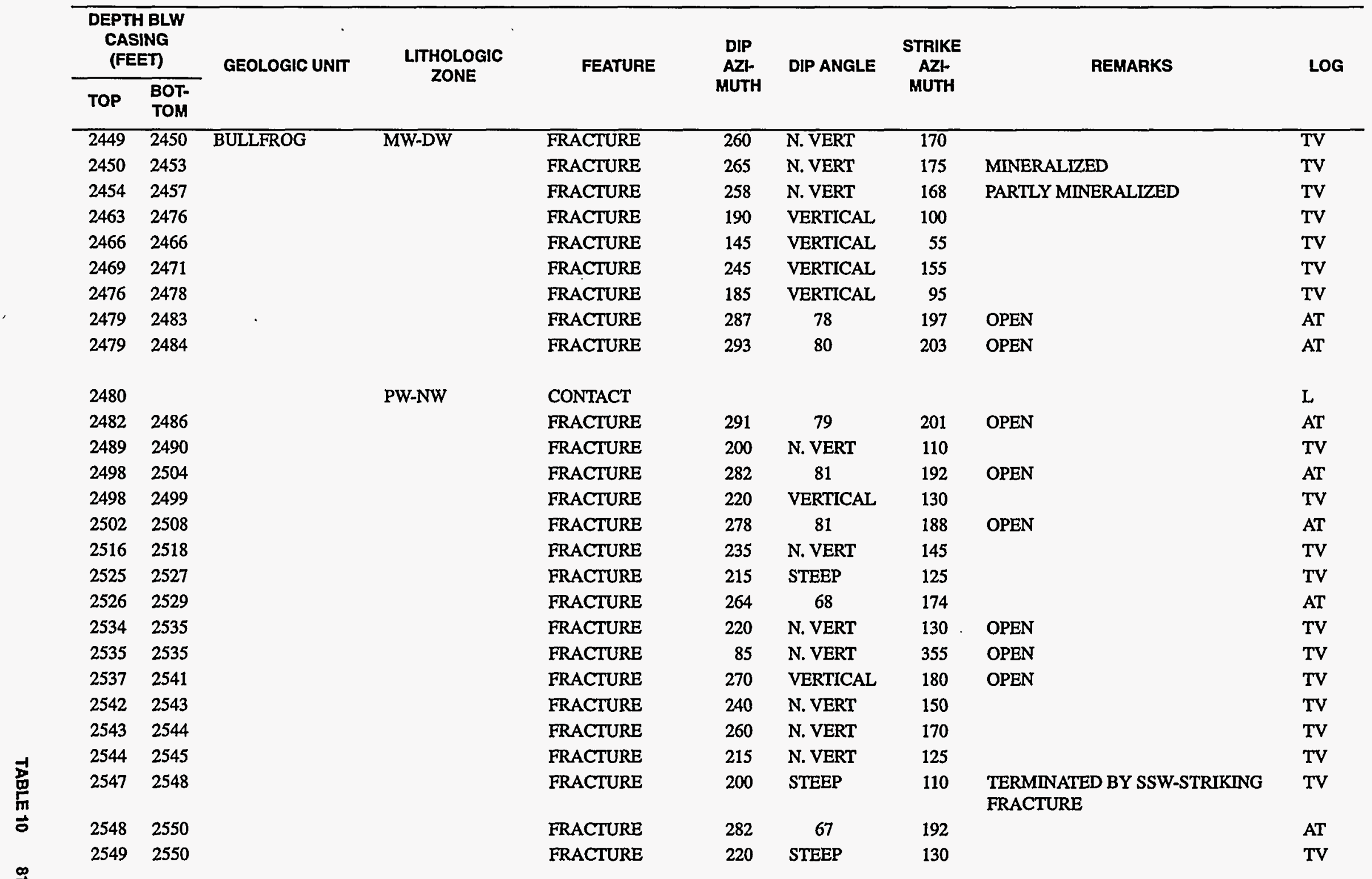


§ TABLE 10. SUMMARY OF INFORMATION FROM LITHOLOGIC (L), TELEVISION (TV), ACOUSTIC TELEVIEWER (AT), CALIPER (C), AND TEMPERATURE (TEMP) LOGS FOR BOREHOLE UE-25C \#1 --Continued

\begin{tabular}{|c|c|c|c|c|c|c|c|c|c|}
\hline \multicolumn{2}{|c|}{$\begin{array}{l}\text { DEPTH BLW } \\
\text { CASING } \\
\text { (FEET) }\end{array}$} & \multirow[t]{2}{*}{ GEOLOGIC UNIT } & \multirow{2}{*}{$\begin{array}{l}\text { LITHOLOGIC } \\
\text { ZONE }\end{array}$} & \multirow{2}{*}{ FEATURE } & \multirow{2}{*}{$\begin{array}{c}\text { DIP } \\
\text { AZI- } \\
\text { MUTH }\end{array}$} & \multirow[t]{2}{*}{ DIP ANGLE } & \multirow{2}{*}{$\begin{array}{c}\text { STRIKE } \\
\text { AZI- } \\
\text { MUTH }\end{array}$} & \multirow[t]{2}{*}{ REMARKS } & \multirow[t]{2}{*}{ LOG } \\
\hline TOP & $\begin{array}{l}\text { BOT- } \\
\text { TOM }\end{array}$ & & & & & & & & \\
\hline 2554 & 2556 & BÜLLFROG & PW-NW & FRACTURE & 260 & N. VERT & 170 & & TV \\
\hline 2558 & 2560 & & & FRACTURE & 277 & 70 & 187 & OPEN, CAVING & $\mathrm{AT}$ \\
\hline 2565 & 2566 & & & FRACTURE & 205 & N. VERT & 115 & & TV \\
\hline 2568 & 2569 & & & FRACTURE & 135 & STEEP & 45 & & TV \\
\hline 2572 & 2572 & & & FRACTURE & 295 & SHALLOW & 205 & $\begin{array}{l}\text { OPEN; HOLE ENLARGED BY } \\
\text { FRACTURES 2572-2573 }\end{array}$ & TV \\
\hline 2572 & 2572 & & & FRACTURE & 80 & SHALLOW & 350 & OPEN & TV \\
\hline 2572 & 2573 & & & FRACTURE & 165 & VERTICAL & 75 & OPEN & TV \\
\hline 2572 & 2573 & & & FRACTURE & 195 & VERTICAL & 105 & OPEN & $\mathrm{TV}$ \\
\hline 2574 & 2575 & & & FRACTURE & 150 & SHALLOW & 60 & $\begin{array}{l}\text { OPEN; HOLE ENLARGED BY } \\
\text { FRACTURES } 2574-2575\end{array}$ & TV \\
\hline 2574 & 2575 & & & FRACTURE & 150 & SHALLOW & 60 & OPEN & $\mathrm{TV}$ \\
\hline 2574 & 2575 & & & FRACTURE & 90 & N. VERT & 0 & & TV \\
\hline 2574 & 2575 & & & FRACTURE & 83 & 32 & 353 & OPEN & $\mathrm{AT}$ \\
\hline 2577 & 2578 & & & FRACTÚRE & 105 & SHALLOW & 15 & $\begin{array}{l}\text { OPEN; HOLE ENLARGED BY } \\
\text { FRACTURES } 2577-2579\end{array}$ & TV \\
\hline 2578 & 2578 & & & FRACTURE & 110 & SHALLOW & 20 & OPEN & TV \\
\hline 2578 & 2579 & & & FRACTURE & 110 & SHALLOW & 20 & OPEN & TV \\
\hline 2588 & 2589 & & & FRACTURE & 122 & SHALLOW & 32 & & TV \\
\hline 2590 & 2591 & & & FRACTURE & 85 & SHALLOW & $355^{\circ}$ & & TV \\
\hline 2590 & 2591 & & & FRACTURE & 85 & SHALLOW & 355 & & TV \\
\hline 2594 & 2595 & & & FRACTURE & 110 & SHALLOW & 20 & & TV \\
\hline 2603 & 2604 & & & FRACTURE & 105 & SHALLOW & 15 & & TV \\
\hline 2656 & 2657 & & & FRACTURE & 80 & SHALLOW & 350 & & TV \\
\hline 2677 & 2679 & & & FRACTURE & 110 & STEEP & 20 & & TV \\
\hline 2682 & 2684 & & & FRACTURE & 108 & STEEP & 18 & & TV \\
\hline 2694 & 2695 & & & FRACTURE & 108 & SHALLOW & 18 & & TV \\
\hline 2695 & & & BEDDED & CONTACT & & & & & $\mathrm{L}$ \\
\hline 2698 & 2699 & & & FRACTURE & 95 & SHALLOW & 5 & & TV \\
\hline 2703 & 2704 & & & FRACTURE & 110 & SHALLOW & 20 & & TV \\
\hline
\end{tabular}


TABLE 10. SUMMARY OF INFORMATION FROM LITHOLOGIC (L), TELEVISION (TV), ACOUSTIC TELEVIEWER (AT), CALIPER (C), AND TEMPERATURE (TEMP) LOGS FOR BOREHOLE UE-25C \#1 -Continued

\begin{tabular}{|c|c|c|c|c|c|c|c|c|c|}
\hline \multicolumn{2}{|c|}{$\begin{array}{l}\text { DEPTH BLW } \\
\text { CASING } \\
\text { (FEET) }\end{array}$} & \multirow[t]{2}{*}{ GEOLOGIC UNIT } & \multirow{2}{*}{$\begin{array}{l}\text { LITHOLOGIC } \\
\text { ZONE }\end{array}$} & \multirow[t]{2}{*}{ FEATURE } & \multirow{2}{*}{$\begin{array}{c}\text { DIP } \\
\text { AZZ- } \\
\text { MUTH }\end{array}$} & \multirow[t]{2}{*}{ DIP ANGLE } & \multirow{2}{*}{$\begin{array}{c}\text { STRIKE } \\
\text { AZI- } \\
\text { MUTH }\end{array}$} & \multirow[t]{2}{*}{ REMARKS } & \multirow[t]{2}{*}{ LOG } \\
\hline TOP & $\begin{array}{l}\text { BOT- } \\
\text { TOM }\end{array}$ & & & & & & & & \\
\hline 2715 & 2715 & & & FRACTURE & 110 & SHALLOW & 20 & & TV \\
\hline 2716 & & TRAM & UPPER (NW-PW) & CONTACT & & & & & TV \\
\hline 2730 & 2731 & & & FRACTURE & 105 & SHALLOW & 15 & & TV \\
\hline 2730 & 2731 & & & FRACTURE & 300 & VERTICAL & 210 & & TV \\
\hline 2731 & $27 \dot{33}$ & & & FRACTURE & 127 & 56 & 37 & & TV \\
\hline 2731 & 2734 & & & FRACTURE & 297 & 68 & 207 & & $\mathrm{AT}$ \\
\hline 2732 & 2733 & I & & FRACTURE & 285 & N. VERT & 195 & & AT \\
\hline 2733 & 2733 & & & FRACTURE & 210 & VERTICAL & 120 & & TV \\
\hline 2743 & 2750 & & & FRACTURE & 355 & VERTICAL & 265 & $\begin{array}{l}\text { CAVERNOUS; HOLE FOLLOWS } \\
\text { FRACTURE }\end{array}$ & $\mathrm{TV}$ \\
\hline 2750 & 2752 & & & FRACTURE & 300 & 55 & 210 & & AT \\
\hline 2759 & 2760 & & & FRACTURE & 290 & N. VERT & 200 & OPEN & TV \\
\hline 2761 & 2761 & & & FRACTURE & 305 & SHALLOW & 215 & OPEN & TV \\
\hline 2762 & 2763 & & & FRACTURE & 305 & SHALLOW & 215 & & TV \\
\hline 2762 & 2764 & & & FRACTURE & 280 & 64 & 190. & & AT \\
\hline 2763 & 2764 & & & FRACTURE & 205 & STEEP & 115 & CAVERNOUS UPTOE & TV \\
\hline 2763 & 2764 & & & FRACTURE & 35 & SHALLOW & 305 & & TV \\
\hline 2764 & 2765 & & & FRACTURE & 305 & 64 & 215 & & $\mathrm{AT}$ \\
\hline 2765 & 2766 & & & FRACTURE & 0 & SHALLOW & 270 & & TV \\
\hline 2766 & 2767 & & & FRACTURE & 293 & 62 & 203 & & $\mathrm{AT}$ \\
\hline
\end{tabular}


I TABLE 10. SUMMARY OF INFORMATION FROM LITHOLOGIC (L), TELEVISION (TV), ACOUSTIC TELEVIEWER (AT), CALIPER (C), AND TEMPERATURE (TEMP) LOGS FOR BOREHOLE UE-25C \#1 --Continued

DEPTH BLW
CASING

CASING
(FEET)

GEOLOGICUNT

\begin{tabular}{lll} 
(FEET) & GEOLOGIC UNIT & $\begin{array}{c}\text { LTHOLOGIC } \\
\text { ZONE }\end{array}$ \\
\hline TOP BOT- & FEATURE
\end{tabular}

\begin{tabular}{lllll}
\hline 2766 & 2768 & TRAM & UPPER (NW-PW) & FRACTURE
\end{tabular}

$2767 \quad 2768$

$2768 \quad 2768$

$2768 \quad 2768$

$2768 \quad 2770$

$2770 \quad 2771$

$2770 \quad 2772$

$2772 \quad 2773$

$2773 \quad 2774$

$2774 \quad 2775$

2775

$2776 \quad 2776$

$2777 \quad 2777$

$2777 \quad 2779$

$2777 \quad 2779$

$2780 \quad 2782$

$2782 \quad 2783$

$2784 \quad 2784$

$2784 \quad 2786$

$2784 \quad 2786$

$\begin{array}{ll}2784 & 2784\end{array}$

$2787 \quad 2789$

$2788 \quad 2790$

$2790 \quad 2791$

$2791 \quad 2791$

$2791 \quad 2791$

$2794 \quad 2795$

FRACTURE

FRACTURE

FRACTURE

FRACTURE

FRACTURE

FRACTURE

FRACTURE

DIP

STRIKE

AZI-

REMARKS

LOG

FRACTURE

299

$64 \quad 209$

$64 \quad 213$

STEEP 240

STEEP

245

335

279

279

266

266
278

$\begin{array}{ll}61 & 189\end{array}$

$\begin{array}{ll}59 & 176\end{array}$

$\begin{array}{ll}59 & 176 \\ 66 & 188\end{array}$

$\begin{array}{lll}289 & 58 & 199\end{array}$

284

57

199

194

$53 \quad 201$

TUFF BRECCIA

CONTACT

FRACTURE

FRACTURE

SHALLOW

STEEP

215

FRACTURE

STEEP

FRACTURE

FRACTURE

FRACTURE

FRACTURE

FRACTURE

FRACTURE

FRACTURE

FRACTURE

STEEP

63

197

320

$64 \quad 203$

$48 \quad 176$

STEEP $\quad 150$

FRACTURE

FRACTURE

FRACTURE

FRACTURE

FRACTURE

65

185

OPEN; HOLE ENLARGED BY

FRACTURES 2777-2779

AT

AT

L

TV

TV

TV

TV

AT

AT

TV

AT

AT

PAINTBRUSH CANYON FAULT ON LITH LOG

$64 \quad 192$

AT/L

N. VERT

192
20

AT

N. VERT

255

N. VERT 300

TV

TV

TV 
TABLE 10. SUMMARY OF INFORMATION FROM LITHOLOGIC (L), TELEVISION (TV), ACOUSTIC TELEVIEWER (AT), CALIPER (C), AND TEMPERATURE (TEMP) LOGS FOR BOREHOLE UE-25C \#1 -Continued

\begin{tabular}{|c|c|c|c|c|c|c|c|c|c|}
\hline \multicolumn{2}{|c|}{$\begin{array}{l}\text { DEPTH BLW } \\
\text { CASING } \\
\text { (FEET) }\end{array}$} & \multirow[t]{2}{*}{ GEOLOGIC UNIT } & \multirow{2}{*}{$\begin{array}{l}\text { LTHOLOGIC } \\
\text { ZONE }\end{array}$} & \multirow[t]{2}{*}{ FEATURE } & \multirow{2}{*}{$\begin{array}{c}\text { DIP } \\
\text { AZI- } \\
\text { MUTH }\end{array}$} & \multirow[t]{2}{*}{ DIP ANGLE } & \multirow{2}{*}{$\begin{array}{l}\text { STRIKE } \\
\text { AZI- } \\
\text { MUTH }\end{array}$} & \multirow[t]{2}{*}{ REMARKS } & \multirow[t]{2}{*}{ LOG } \\
\hline TOP & $\begin{array}{l}\text { BOT- } \\
\text { TOM }\end{array}$ & & & & & & & & \\
\hline 2794 & 2795 & & & FRACTURE & 200 & N. VERT & 110 & & TV \\
\hline 2795 & 2795 & & & FRACTURE & 345 & VERTICAL & 255 & & TV \\
\hline 2795 & 2795 & & & FRACTURE & 155 & N. VERT & 65 & & TV \\
\hline 2796 & 2802 & & & FRACTURE & 116 & 82 & 26 & OPEN & AT \\
\hline 2802 & 2802 & & & FRACTURE & 175 & N. VERT & 85 & & TV \\
\hline 2803 & 2804 & & & FRACTURE & 200 & N. VERT & 110 & & TV \\
\hline 2804 & 2804 & & & FRACTURE & 200 & N. VERT & 110 & & TV \\
\hline 2814 & 2816 & & & FRACTURE & 220 & N. VERT & 130 & & TV \\
\hline 2816 & 2820 & & & FRACTURE & 255 & 76 & 165 & & AT \\
\hline 2832 & 2833 & & & FRACTURE & 65 & N. VERT & 335 & CAVING ALONG FRACTURE FACE & TV \\
\hline 2836 & 2837 & & & FRACTURE & 50 & N. VERT & 320 & & TV \\
\hline 2836 & 2838 & & & FRACTURE & 70 & N. VERT & 340 & & TV \\
\hline 2837 & 2838 & & & FRACTURE & 10 & STEEP & 280 & MINERALIZED & TV \\
\hline 2838 & 2839 & & & FRACTURE & 164 & 56 & 74 & & $\mathrm{AT}$ \\
\hline 2840 & 2840 & & & FRACTURE & 285 & N. VERT & 195 & - & TV \\
\hline 2843 & 2844 & & & FRACTURE & 35 & SHALLOW & 305 & MINERALIZED & TV \\
\hline 2843 & 2844 & & & FRACTURE & 20 & SHALLOW & 290 & MINERALIZED & TV \\
\hline 2845 & 2845 & & & FRACTURE & 15 & SHALLOW & 285 & MINERALIZED & TV \\
\hline 2845 & 2847 & & & FRACTURE & 20 & STEEP & 290 & MINERALIZED & TV \\
\hline 2850 & 2851 & & & FRACTURE & 15 & STEEP & 285 & MINERALIZED & TV \\
\hline
\end{tabular}


§ TABLE 10. SUMMARY OF INFORMATION FROM LITHOLOGIC (L), TELEVISION (TV), ACOUSTIC TELEVIEWER (AT), CALIPER (C), AND TEMPERATURE

(TEMP) LOGS FOR BOREHOLE UE-25C \#1 --Continued

\begin{tabular}{|c|c|c|c|c|c|c|c|c|c|}
\hline \multicolumn{2}{|c|}{$\begin{array}{l}\text { DEPTH BLW } \\
\text { CASING } \\
\text { (FEET) }\end{array}$} & \multirow[t]{2}{*}{ GEOLOGIC UNIT } & \multirow{2}{*}{$\begin{array}{l}\text { LITHOLOGIC } \\
\text { ZONE }\end{array}$} & \multirow[t]{2}{*}{ FEATURE } & \multirow{2}{*}{$\begin{array}{c}\text { DIP } \\
\text { AZI- } \\
\text { MUTH }\end{array}$} & \multirow{2}{*}{ DIP ANGLE } & \multirow{2}{*}{$\begin{array}{c}\text { STRIKE } \\
\text { AZI- } \\
\text { MUTH }\end{array}$} & \multirow{2}{*}{ REMARKS } & \multirow[t]{2}{*}{ LOG } \\
\hline TOP & $\begin{array}{l}\text { BOT- } \\
\text { TOM }\end{array}$ & & & & & & & & \\
\hline 2854 & 2857 & TRAM & TUFF BRECCLA & FRACTURE & 80 & N. VERT & 350 & & TV \\
\hline 2854 & 2857 & & & FRACTURE & 75 & N. VERT & 345 & & TV \\
\hline 2856 & 2856 & & & FRACTURE & 35 & SHALLOW & 305 & MINERALIZED & TV \\
\hline 2857 & 2858 & & & FRACTURE & 255 & N. VERT & 165 & - & TV \\
\hline 2858 & 2859 & & & FRACTURE & 65 & SHALLOW & 335 & PARTLY MINERALIZED & TV \\
\hline 2859 & 2860 & & & FRACTURE & 265 & N. VERT & 175 & & TV \\
\hline 2860 & 2860 & & & FRACTURE & 65 & SHALLOW & 335 & MINERALIZED & TV \\
\hline 2860 & 2863 & & & FRACTURE & 60 & N. VERT & 330 & OPEN & TV \\
\hline 2863 & 2866 & & & FRACTURE & 121 & 71 & 31 & & AT \\
\hline 2865 & 2867 & & & FRACTURE & 270 & STEEP & 160 & & TV. \\
\hline 2866 & 2868 & & & FRACTURE & 115 & N. VERT & 25 & MINERALIZED & TV \\
\hline 2867 & 2870 & & & FRACTURE & 279 & 68 & 189 & & AT \\
\hline 2868 & 2868 & & & FRACTURE & 125 & N. VERT & 35 & MINERALIZED & TV \\
\hline 2868 & 2870 & & & FRACTURE & 70 & STEEP & 340 & & TV \\
\hline 2870 & 2870 & & & FRACTURE & 5 & SHALLOW & 275 & MINERALIZED & TV \\
\hline 2870 & 2872 & & & FRACTURE & 55 & SHALLOW & 325 & & AT \\
\hline 2872 & 2873 & & & FRACTURE & 119 & 64 & 29 & & TV \\
\hline 2872 & 2872 & & & FRACTURE & 270 & VERTICAL & 180 & & TV \\
\hline 2872 & 2872 & & & FRACTURE & 95 & VERTICAL & 5 & & TV \\
\hline 2872 & 2876 & & & FRACTURE & 65 & N. VERT & 335 & & TV \\
\hline 2873 & 2873 & & & FRACTURE & 180 & N. VERT & 90 & & TV \\
\hline 2874 & 2874 & & & FRACTURE & 265 & VERTICAL & 175 & & TV \\
\hline 2875 & 2878 & & & FAULT & 320 & VERTICAL & 230 & $\begin{array}{l}\text { OFFSETS SE-STRIKING FRACTURE } \\
\text { AT } 2877\end{array}$ & TV \\
\hline 2875 & 2875 & & & FRACTURE & 290 & VERTICAL & 200 & & TV \\
\hline 2876 & 2876 & & & FRACTURE & 180 & SHALLOW & 90 & PARTLY MINERALIZED & TV \\
\hline 2876 & 2876 & & & FRACTURE & 250 & N. VERT & 160 & & TV \\
\hline 2877 & 2877 & & & FRACTURE & 0 & SHALLOW & 270 & PARTLY MINERALIZED & TV \\
\hline 2877 & 2880 & & & FRACTURE & 210 & N. VERT & 120 & & TV \\
\hline 2878 & 2879 & & & FRACTURE & 95 & N. VERT & 5 & & TV \\
\hline 2879 & 2879 & & & FRACTURE & 305 & VERTICAL & 215 & & TV \\
\hline
\end{tabular}


TABLE 10. SUMMARY OF INFORMATION FROM LITHOLOGIC (L), TELEVISION (TV), ACOUSTIC TELEVIEWER (AT), CALIPER (C), AND TEMPERATURE (TEMP) LOGS FOR BOREHOLE UE-25C \#1 -Continued

\begin{tabular}{|c|c|c|c|c|c|c|c|c|c|}
\hline \multicolumn{2}{|c|}{$\begin{array}{l}\text { DEPTH BLW } \\
\text { CASING } \\
\text { (FEET) }\end{array}$} & \multirow[t]{2}{*}{ GEOLOGIC UNTT } & \multirow{2}{*}{$\begin{array}{l}\text { LITHOLOGIC } \\
\text { ZONE }\end{array}$} & \multirow[t]{2}{*}{ FEATURE } & \multirow{2}{*}{$\begin{array}{c}\text { DIP } \\
\text { AZI- } \\
\text { MUTH }\end{array}$} & \multirow[t]{2}{*}{ DIP ANGLE } & \multirow{2}{*}{$\begin{array}{c}\text { STRIKE } \\
\text { AZI- } \\
\text { MUTH }\end{array}$} & \multirow[t]{2}{*}{ REMARKS } & \multirow[t]{2}{*}{ LOG } \\
\hline TOP & $\begin{array}{l}\text { BOT- } \\
\text { TOM }\end{array}$ & & & & & & & & \\
\hline 2879 & 2880 & & & FRACTURE & 350 & SHALLOW & 260 & MINERALIZED & TV \\
\hline 2880 & 2881 & & & FRACTURE & 50 & STEEP & 320 & & TV \\
\hline 2881 & 2882 & & & FRACTURE & 310 & SHALLOW & 220 & MINERALIZED & $\mathrm{TV}$ \\
\hline 2882 & 2884 & & & FRACTURE & 35 & STEEP & 305 & & TV \\
\hline 2884 & 2884 & & & FRACTURE & 135 & N. VERT & 45 & & TV \\
\hline 2884 & 2884 & & & FRACTURE & 210 & STEEP & 120 & & TV \\
\hline 2886 & 2886 & & & FRACTURE & 35 & SHALLOW & 305 & PARTLY MINERALIZED & TV \\
\hline 2888 & 2889 & & & FRACTURE & 50 & SHALLOW & 320 & PARTLY MINERALIZED & TV \\
\hline 2889 & 2889 & & & FRACTURE & 40 & SHALLOW & 310 & MINERALIZED & TV \\
\hline 2893 & 2893 & & & FRACTURE & 260 & N. VERT & 170 & & TV \\
\hline 2893 & 2896 & & & FRACTURE & 290 & 74 & 200 & & AT \\
\hline 2894 & 2894 & & & FRACTURE & 0 & SHALLOW & 270 & MINERALIZED & TV \\
\hline 2899 & 2900 & & & FRACTURE & 25 & N. VERT & 295 & CAVING ALONG FRACTURE FACE & TV \\
\hline 2901 & 2901 & & & FRACTURE & 255 & N. VERT & 165 & & TV \\
\hline 2901 & 2909 & & & FRACTURE & 155 & VERTICAL & 65 & & TV \\
\hline 2902 & 2902 & & & FRACTURE & 85 & N. VERT & 355 & & TV \\
\hline 2908 & 2908 & & & FRACTURE & 130 & N. VERT & 40 & & TV \\
\hline 2911 & 2912 & & & FRACTURE & 220 & N. VERT & 130 & & TV \\
\hline 2912 & 2912 & & & FRACTURE & 225 & VERTICAL & 135 & & TV \\
\hline 2913 & 2913 & & & FRACTURE & 105 & N. VERT & 15 & MINERALIZED & $\mathrm{TV}$ \\
\hline 2914 & 2915 & & & FRACTURE & 245 & N. VERT & 155 & & TV \\
\hline
\end{tabular}




\begin{tabular}{|c|c|c|c|c|c|c|c|c|c|}
\hline \multicolumn{2}{|c|}{$\begin{array}{l}\text { DEPTH BLW } \\
\text { CASING } \\
\text { (FEET) }\end{array}$} & \multirow[t]{2}{*}{ GEOLOGIC UNIT } & \multirow{2}{*}{$\begin{array}{l}\text { LTTHOLOGIC } \\
\text { ZONE }\end{array}$} & \multirow{2}{*}{ FEATURE } & \multirow{2}{*}{$\begin{array}{l}\text { DIP } \\
\text { AZI- } \\
\text { MUTH }\end{array}$} & \multirow[t]{2}{*}{ DIP ANGLE } & \multirow{2}{*}{$\begin{array}{c}\text { STRIKE } \\
\text { AZI- } \\
\text { MUTH }\end{array}$} & \multirow[t]{2}{*}{ REMARKS } & \multirow[t]{2}{*}{ LOG } \\
\hline TOP & $\begin{array}{l}\text { BOT- } \\
\text { TOM }\end{array}$ & & & & & & & & \\
\hline 2921 & 2921 & TRAM & TUFF BRECCIA & FRACTURE & 55 & VERTICAL & 325 & & TV \\
\hline 2921 & 2922 & & & FRACTURE & 15 & N. VERT & 285 & & TV \\
\hline 2922 & 2923 & & & FRACTURE & 265 & STEEP & 175 & & TV \\
\hline 2923 & 2924 & & & FRACTURE & 260 & STEEP & 170 & & TV \\
\hline 2924 & 2924 & & & FRACTURE & 80 & N. VERT & 350 & & TV \\
\hline 2924 & 2925 & & & FRACTURE & 260 & STEEP & 170 & & $\mathrm{TV}$ \\
\hline 2925 & 2925 & & & FRACTURE & 60 & STEEP & 330 & & $\mathrm{TV}$ \\
\hline 2925 & 2927 & & & FRACTURE & 60 & STEEP & 330 & & TV \\
\hline 2926 & 2926 & & & FRACTURE & 50 & STEEP & 320 & & $\mathrm{TV}$ \\
\hline 2926 & 2926 & & & FRACTURE & 90 & N. VERT & 0 & & TV \\
\hline 2929 & 2930 & & & FRACTURE & 115 & N. VERT & 25 & & $\mathrm{TV}$ \\
\hline 2930 & 2930 & & & FRACTURE & 105 & N. VERT & 15 & & $\mathrm{TV}$ \\
\hline 2930 & 2931 & & & FRACTURE & 310 & SHALLOW & 220 & & TV \\
\hline 2933 & 2933 & & & FRACTURE & 280 & N. VERT & 190 & 冫 & TV \\
\hline 2935 & 2935 & & & FRACTURE & 70 & SHALLOW & 340 & OPEN & TV \\
\hline 2935 & 2936 & & & FRACTURE & 130 & N. VERT & 40 & & $\mathrm{TV}$ \\
\hline 2936 & 2937 & & & FRACTURE & 185 & N. VERT & 95 & & $\mathrm{TV}$ \\
\hline 2937 & 2937 & & & FRACTURE & 65 & N. VERT & 335 & . & TV \\
\hline 2940 & 2940 & & & FRACTURE & 305 & N. VERT & 215 & & TV \\
\hline 2941 & 2941 & & & FRACTURE & 250 & N. VERT & 160 & & TV \\
\hline 2954 & 2955 & & & FRACTURE & 285 & N. VERT & 195 & & TV \\
\hline 2962 & & & & ВотTOM & & & & $\begin{array}{l}\text { HOLE CAVED TO ORIGINAL TD } \\
\text { AT } 3000\end{array}$ & $\mathrm{TV}$ \\
\hline
\end{tabular}


TABLE 11. SUMMARY OF INFORMATION FROM LITHOLOGIC (L), TELEVISION (TV), ACOUSTIC TELEVIEWER (AT), CALIPER (C), AND TEMPERATURE (TEMP) LOGS FOR BOREHOLE UE-25C \#2

[Abbreviations for tables 10,11, and 12: CSG, casing; NW, nonwelded; NW-PW, nonwelded to partially welded; MW, moderately welded; MW-DW, moderately to densely welded; PW-NW, partially welded to nonwelded; PW, partially welded; N.VERT, near vertical; LTTH, lithologic; TD, total depth; N, north, S, south; SW, southwest, SE, southeast; SSW, south-southwest]

\begin{tabular}{|c|c|c|c|c|c|c|c|c|c|}
\hline \multicolumn{2}{|c|}{$\begin{array}{l}\text { DEPTH BLW } \\
\text { CASING } \\
\text { (FEET) }\end{array}$} & \multirow[t]{2}{*}{ GEOLOGIC UNIT } & \multirow{2}{*}{$\begin{array}{l}\text { LITHOLOGIC } \\
\text { ZONE }\end{array}$} & \multirow[t]{2}{*}{ FEATURE } & \multirow{2}{*}{$\begin{array}{c}\text { DIP } \\
\text { AZI- } \\
\text { MUTH }\end{array}$} & \multirow[t]{2}{*}{ DIP ANGLE } & \multirow{2}{*}{$\begin{array}{c}\text { STRIKE } \\
\text { AZI- } \\
\text { MUTH }\end{array}$} & \multirow[t]{2}{*}{ REMARKS } & \multirow[t]{2}{*}{ LOG } \\
\hline TOP & $\begin{array}{l}\text { BOT: } \\
\text { TOM }\end{array}$ & & & & & & & & \\
\hline 1315 & & TOPOPAH SPRING & BASAL & WATER TABLE & & & & & TV \\
\hline 1316 & & CALICO HIILS & NW & CONTACT & & & & & $\mathbf{L}$ \\
\hline 1360 & & & & CSG BOTTOM & & & & & TV \\
\hline 1360 & 1365 & & & CONCRETE & & & & $\begin{array}{l}\text { ROUGH; SPALLED; HOLE } \\
\text { ABRUPTLY WIDENS BELOW }\end{array}$ & $\mathrm{TV} / \mathrm{C}$ \\
\hline 1395 & 1396 & & & FRACTURE & 235 & 35 & 145 & $\begin{array}{l}\text { VISIBILITY IMPAIRED 1365-1515 BY } \\
\text { SKEWED HOLE }\end{array}$ & $\mathrm{AT}$ \\
\hline 1461 & 1469 & & & FRACTURE & 65 & 81 & 335 & & AT \\
\hline 1461 & 1470 & & & FRACTURE & 65 & 82 & 335 & & AT \\
\hline 1465 & 1472 & & & FRACTURE & 95 & 79 & 5 & & $\mathrm{AT}$ \\
\hline 1467 & 1477 & & ' & FRACTURE & 75 & 82 & 345 & & $\mathrm{AT}$ \\
\hline 1510 & 1511 & & & FRACTURE & 255 & $>35$ & 165 & & TV \\
\hline 1514 & 1534 & & & FRACTURE & 65 & 86 & 335 & OPEN & AT/TV \\
\hline 1515 & 1515 & & & LEDGE & & & & HOLE DIAMETER REDUCED & TV \\
\hline 1518 & 1539 & & & FRACTURE & 70 & 87 & 340 & OPEN & AT/TV \\
\hline 1550 & 1555 & & & FRACTURE & 90 & $>78$ & 0 & & $\mathrm{TV}$ \\
\hline 1552 & 1552 & & & FRACTURE & 120 & VERTICAL & 30 & & TV \\
\hline 1570 & & & BEDDED & CONTACT & & & & & $\mathbf{L}$ \\
\hline 1600 & 1600 & & & FRACTURE & 120 & 32 & 30 & & TV \\
\hline 1624 & 1625 & & & FRACTURE & 120 & 43 & 30 & & TV \\
\hline 1624 & 1625 & & & FRACTURE & 120 & 27 & 30 & & TV \\
\hline 1626 & 1626 & & & FRACTURE & 120 & 27 & 30 & & TV \\
\hline 1626 & 1626 & & & FRACTURE & 115 & 43 & 25 & & TV \\
\hline 1627 & 1627 & & & FRACTURE & 105 & 36 & 15 & & TV \\
\hline 1627 & 1628 & & & FRACTURE & 110 & 36 & 20 & & TV \\
\hline 1628 & 1629 & & & FRACTURE & 120 & 45 & 30 & MINERALIZED & TV \\
\hline 1629 & 1630 & & & FRACTURE & 75 & 35 & 345 & & AT \\
\hline 1630 & 1631 & & & FRACTURE & 100 & 48 & 10 & PARTLY MINERALIZED & TV \\
\hline
\end{tabular}


\& TABLE 11. SUMMARY OF INFORMATION FROM LITHOLOGIC (L), TELEVISION (TV), ACOUSTIC TELEVIEWER (AT), CALIPER (C), AND TEMPERATURE

(TEMP) LOGS FOR BOREHOLE UE-25C \#2 --Continued

\begin{tabular}{|c|c|c|c|c|c|c|c|c|c|}
\hline \multicolumn{2}{|c|}{$\begin{array}{l}\text { DEPTH BLW } \\
\text { CASING } \\
\text { (FEET) }\end{array}$} & \multirow{2}{*}{ GEOLOGIC UNIT } & \multirow{2}{*}{$\begin{array}{l}\text { LTHOLOGIC } \\
\text { ZONE }\end{array}$} & \multirow{2}{*}{ FEATURE } & \multirow{2}{*}{$\begin{array}{c}\text { DIP } \\
\text { AZI- } \\
\text { MUTH }\end{array}$} & \multirow{2}{*}{ DIP ANGLE } & \multirow{2}{*}{$\begin{array}{l}\text { STRIKE } \\
\text { AZI- } \\
\text { MUTH }\end{array}$} & \multirow{2}{*}{ REMARKS } & \multirow{2}{*}{ LOG } \\
\hline TOP & $\begin{array}{l}\text { BOT- } \\
\text { TOM }\end{array}$ & & & & & & & & \\
\hline 1631 & 1632 & CALICO HILLS & BEDDED & FRACTURE & 110 & 48 & 20 & MINERALIZED & TV \\
\hline 1632 & 1633 & & & FRACTURE & 110 & 40 & 20 & MINERALIZED & TV \\
\hline 1633 & 1634 & & & FRACTURE & 105 & 42 & 15 & & $\mathrm{AT}$ \\
\hline 1644 & 1645 & & & FRACTURE & 110 & 40 & 20 & OPEN & TV \\
\hline 1645 & 1645 & & & FRACTURE & 145 & VERTICAL & 55 & & TV \\
\hline 1645 & 1650 & & & FRACTURE & 75 & 78 & 345 & $\begin{array}{l}\text { OPEN AT INTERSĖCTION WITH } \\
\text { SE-STRIKING FRACTURE }\end{array}$ & TV \\
\hline 1646 & 1650 & & & FRACTURE & 225 & 74 & 135 & $\begin{array}{l}\text { OPEN AT INTERSECTION WITH } \\
\text { N-STRIKING FRACTURE }\end{array}$ & TV \\
\hline 1650 & 1653 & & & FRACTURE & 255 & $68^{\circ}$ & 165 & & $\mathrm{AT}$ \\
\hline 1652 & 1652 & & & FRACTURE & 115 & 27 & 25 & MINERALIZED & TV \\
\hline 1652 & 1653 & & & FRACTURE & 15 & VERTICAL & 285 & & TV \\
\hline 1653 & 1653 & & & FRACTURE & 225 & VERTICAL & 135 & & TV \\
\hline 1653 & 1653 & & & FRACTURE & 320 & VERTICAL & 230 & & TV \\
\hline 1653 & 1654 & & & FRACTURE & 270 & 27 & 180 & $\begin{array}{l}\text { ROCK CHANGES COLOR BELOW } \\
\text { FRACTURE }\end{array}$ & TV \\
\hline 1654 & 1654 & & & FRACTURE & 20 & 27 & 290 & MINERAIIZED & TV \\
\hline 1655 & 1655 & & & FRACTURE & 75 & 22 & 345 & MINERALIZED & TV \\
\hline 1655 & 1656 & & & FRACTURE. & 155 & STEEP & 65 & MINERALIZED & TV \\
\hline 1655 & 1656 & & & FRACTURE & 115 & 26 & 25 & MINERALIZED & TV \\
\hline 1655 & 1656 & & & FRACTURE & 115 & 26 & 25 & MINERALIZED & TV \\
\hline 1656 & 1656 & & & FRACTURE & 120 & 26 & 30 & MINERALIZED & TV \\
\hline 1656 & 1657 & & & FRACTURE & 120 & 26 & 30 & MINERALIZED & TV \\
\hline 1658 & 1658 & & & FRACTURE & 120 & 30 & 30 & MINERALIZED & TV \\
\hline 1658 & 1659 & & & FRACTURE & 120 & 30 & 30 & MINERALIZED & TV \\
\hline 1659 & 1659 & & & FRACTURE & 125 & 16 & 35 & MINERALIZED & TV \\
\hline 1659 & 1660 & & & FRACTURE & 125 & 16 & 35 & MINERALIZED & TV \\
\hline 1660 & 1660 & & & FRACTURE & 125 & 21 & 35 & MINERALIZED & TV \\
\hline 1661 & 1662 & & & FRACTURE & 130 & 34 & 40 & MINERALIZED & TV \\
\hline 1663 & 1664 & & & FRACTURE & 130 & 26 & 40 & MINERALIZED & TV \\
\hline 1664 & 1665 & & & FRACTURE & 315 & 22 & 225 & & TV \\
\hline
\end{tabular}


TABLE 11. SUMMARY OF INFORMATION FROM LITHOLOGIC (L), TELEVISION (TV), ACOUSTIC TELEVIEWER (AT), CALIPER (C), AND TEMPERATURE (TEMP) LOGS FOR BOREHOLE UE-25C \#2 --Continued

\begin{tabular}{|c|c|c|c|c|c|c|c|c|c|}
\hline \multicolumn{2}{|c|}{$\begin{array}{l}\text { DEPTH BLW } \\
\text { CASING } \\
\text { (FEET) }\end{array}$} & \multirow[t]{2}{*}{ GEOLOGIC UNIT } & \multirow{2}{*}{$\begin{array}{l}\text { LITHOLOGIC } \\
\text { ZONE }\end{array}$} & \multirow[t]{2}{*}{ FEATURE } & \multirow{2}{*}{$\begin{array}{c}\text { DIP } \\
\text { AZI- } \\
\text { MUTH }\end{array}$} & \multirow[t]{2}{*}{ DIP ANGLE } & \multirow{2}{*}{$\begin{array}{c}\text { STRIKE } \\
\text { AZt- } \\
\text { MUTH }\end{array}$} & \multirow[t]{2}{*}{ REMARKS } & \multirow[t]{2}{*}{ LOG } \\
\hline TOP & $\begin{array}{l}\text { BOT- } \\
\text { TOM }\end{array}$ & & & & & & & & \\
\hline 1665 & 1666 & & & FRACTURE & 110 & N. VERT & 20 & & TV \\
\hline 1666 & 1666 & & & FRACTURE & 135 & 39 & 45 & & TV \\
\hline 1670 & 1670 & & & FRACTURE & 190 & VERTICAL & 100 & & TV \\
\hline 1672 & 1673 & PROW PASS & NW-PW & CONTACT . & & & & $\begin{array}{l}\text { OPEN PARTING; DEAD LIZARD ON } \\
\text { TOP OF PROW PASS }\end{array}$ & TV/L \\
\hline 1676 & 1676 & & & FRACTURE & 115 & 16 & 25 & & TV \\
\hline 1676 & 1677 & & & FRACTURE & 280 & N. VERT & 190 & $\begin{array}{l}\text { TERMINATES AT SE-STRIKING } \\
\text { FRACTURE }\end{array}$ & TV \\
\hline 1676 & 1678 & & & FRACTURE & 202 & 46 & 112 & & TV \\
\hline 1677 & 1678 & & & FRACTURE & 120 & STEEP & 30 & & TV \\
\hline 1787 & 1788 & & & FRACTURE & 300 & VERTICAL & 210 & & TV \\
\hline 1789 & 1789 & & & FRACTURE & 80 & VERTICAL & 350 & MINERALIZED & TV \\
\hline 1790 & 1790 & & & FRACTURE & 35 & VERTICAL & 305 & & TV \\
\hline 1798 & 1800 & & & FRACTURE & 270 & 65 & 180 & MINERALIZED & TV \\
\hline 1801 & 1803 & & & FRACTURE & 200 & VERTICAL & 110 & MINERALIZED & TV \\
\hline 1802 & 1803 & & & CORRUGATED & & & & HORIZONTAL WASHOUTS & TV \\
\hline 1810 & 1811 & & MW & CONTACT & & & & TEXTURE BECOMES SMOOTHER & TV/L \\
\hline 1812 & 1817 & & & FRACTURE & 262 & 80 & 172 & OPEN DOWNTOE & TV \\
\hline 1812 & 1818 & & & FRACTURE & 262 & 81 & 172 & OPEN DOWNTOE & TV \\
\hline 1812 & 1815 & & & FRACTURE & 315 & VERTICAL & 225 & PARTLY MINERALIZED & TV \\
\hline 1818 & 1820 & & & FRACTURE & 280 & 69 & 190 & & TV \\
\hline
\end{tabular}


i TABLE 11. SUMMARY OF INFORMATION FROM LITHOLOGIC (L), TELEVISION (TV), ACOUSTIC TELEVIEWER (AT), CALIPER (C), AND TEMPERATURE (TEMP) LOGS FOR BOREHOLE UE-25C \#2 --Continued

\begin{tabular}{|c|c|c|c|c|c|c|c|c|c|}
\hline \multicolumn{2}{|c|}{$\begin{array}{l}\text { DEPTH BLW } \\
\text { CASING } \\
\text { (FEET) }\end{array}$} & \multirow[t]{2}{*}{ GEOLOGIC UNIT } & \multirow{2}{*}{$\begin{array}{l}\text { LITHOLOGIC } \\
\text { ZONE }\end{array}$} & \multirow[t]{2}{*}{ FEATURE } & \multirow{2}{*}{$\begin{array}{l}\text { DIP } \\
\text { AZI- } \\
\text { MUTH }\end{array}$} & \multirow[t]{2}{*}{ DIP ANGLE } & \multirow{2}{*}{$\begin{array}{c}\text { STRIKE } \\
\text { AZI- } \\
\text { MUTH }\end{array}$} & \multirow[t]{2}{*}{ REMARKS } & \multirow[t]{2}{*}{ LOG } \\
\hline TOP & $\begin{array}{l}\text { BOT- } \\
\text { TOM }\end{array}$ & & & & & & & & \\
\hline 1822 & 1826 & PROW PASS & MW & FRACTURE & 270 & 77 & 180 & & TV \\
\hline 1823 & 1824 & & & FRACTURE & 265 & N. VERT & 175 & MINERALIZED & TV \\
\hline 1826 & 1830 & & & FRACTURE & 275 & 78 & 185 & & TV \\
\hline 1834 & 1836 & & & FRACTURE & 275 & VERTICAL & 185 & & TV \\
\hline 1836 & 1839 & & & FRACTURE & 263 & 72 & 173 & & TV \\
\hline 1840 & & & PW-NW & CONTACT & & & & & $\mathbf{L}$ \\
\hline 1846 & 1849 & & & FRACTURE & 260 & 75 & 170 & & TV \\
\hline 1848 & 1851 & & & FRACTURE & 248 & 74 & 158 & & TV \\
\hline 1848 & 1848 & & & FRACTURE & 150 & 18 & 60 & & TV \\
\hline 1848 & 1849 & & & FRACTURE & 5 & VERTICAL & 275 & MINERALIZED & TV \\
\hline 1849 & 1853 & & & FRACTURE & 270 & 74 & 180 & - & $\mathrm{AT}$ \\
\hline 1851 & 1854 & & & FRACTURE & 260 & 75 & 170 & & $\mathrm{AT}$ \\
\hline 1857 & 1861 & & & FRACTURE & 245 & 77 & 155 & & TV \\
\hline 1866 & 1870 & & & FRACTURE & 215 & 77 & 125 & & TV \\
\hline 1881 & 1883 & & & FRACTURE & 100 & $>57$ & 10 & & TV \\
\hline 1958 & 1959 & & & FRACTURE & 220 & 38 & 130 & & TV \\
\hline 1960 & 1961 & & & WASHOUT? & & & & $\begin{array}{l}\text { HOLE OUT OF ROUND BUT NO } \\
\text { FRACTURES VISIBLE }\end{array}$ & TV \\
\hline 1995 & 1995 & & • & FRACTURE & 260 & 52 & 170 & & TV \\
\hline 2021 & 2022 & & & FRACTURE & 270 & STEEP & 180 & & TV \\
\hline 2022 & 2023 & & & FRACTURE & 305 & N. VERT & 215 & & TV \\
\hline 2025 & 2027 & & & FRACTURE & 305 & 74 & 215 & & $\mathrm{AT}$ \\
\hline 2032 & 2033 & & & FRACTURE & 220 & 28 & 130 & & TV \\
\hline 2035 & 2037 & . & & FRACTURE & 285 & VERTICAL & 195 & & TV \\
\hline 2110 & & & BEDDED & CONTACT & & & & $\begin{array}{l}\text { VISIBILITY IMPAIRED 2055-2122 BY } \\
\text { SKEWED HOLE }\end{array}$ & L \\
\hline 2131 & 2132 & & & FRACTURE & 240 & 28 & 150 & & TV \\
\hline 2132 & 2132 & & & FRACTURE & 242 & 32 & 152 & MINERALIZED & TV \\
\hline 2132 & 2133 & & & FRACTURE & 245 & 36 & 155 & & TV \\
\hline
\end{tabular}


TABLE 11. SUMMARY OF INFORMATION FROM LITHOLOGIC (L), TELEVISION (TV), ACOUSTIC TELEVIEWER (AT), CALIPER (C), AND TEMPERATURE (TEMP) LOGS FOR BOREHOLE UE-25C \#2 --Continued

\begin{tabular}{|c|c|c|c|c|c|c|c|c|c|}
\hline \multicolumn{2}{|c|}{$\begin{array}{l}\text { DEPTH BLW } \\
\text { CASING } \\
\text { (FEET) }\end{array}$} & \multirow[t]{2}{*}{ GEOLOGIC UNIT } & \multirow{2}{*}{$\begin{array}{l}\text { LTHOLOGIC } \\
\text { ZONE }\end{array}$} & \multirow[t]{2}{*}{ FEATURE } & \multirow{2}{*}{$\begin{array}{c}\text { DIP } \\
\text { AZI- } \\
\text { MUTH }\end{array}$} & \multirow[t]{2}{*}{ DIP ANGLE } & \multirow{2}{*}{$\begin{array}{c}\text { STRIKE } \\
\text { AZI- } \\
\text { MUTH }\end{array}$} & \multirow[t]{2}{*}{ REMARKS } & \multirow[t]{2}{*}{ LOG } \\
\hline TOP & $\begin{array}{l}\text { BOT- } \\
\text { TOM }\end{array}$ & & & & & & & & \\
\hline 2134 & 2135 & & & FRACTURE & 165 & 45 & 75 & MINERALIZED & TV \\
\hline 2138 & 2139 & BULLFROG & NW-PW & CONTACT & & & & OPEN PARTING & TV/L \\
\hline 2240 & & & MW-DW & CONTACT & & & & & $\mathbf{L}$ \\
\hline 2252 & 2256 & & & FRACTURE & 280 & 77 & 190 & & $\mathrm{TV}$ \\
\hline 2258 & 2263 & & & FRACTURE & 270 & 80 & 180 & OPEN & $\mathrm{TV}$ \\
\hline 2262 & 2267 & & & FRACTURE & 255 & 79 & 165 & & $\mathrm{AT}$ \\
\hline 2297 & 2298 & & & FRACTURE & 300 & N. VERT & 210 & MINERALIZED & TV \\
\hline 2300 & 2303 & & & FRACTURE & 225 & 71 & 135 & & TV \\
\hline 2300 & 2301 & & & FRACTURE & 195 & N. VERT & 105 & & TV \\
\hline 2302 & 2304 & & & FRACTURE & 230 & 70 & 140 & & TV \\
\hline 2304 & 2305 & & & FRACTURE & 275 & N. VERT & 185 & & TV \\
\hline 2306 & 2309 & & & FRACTURE & 275 & 75 & 185 & & AT \\
\hline 2314 & 2315 & & & FRACTURE & 220 & N. VERT & 130 & OPEN & TV \\
\hline 2330 & 2332 & & & FRACTURE & 270 & N. VERT & 180 & & TV \\
\hline 2335 & 2339 & & & FRACTURE & 285 & 77 & 195 & $\begin{array}{l}\text { MINERALIZED; INTERSECTING } \\
\text { FRACTURES } 2335-2342\end{array}$ & AT \\
\hline 2336 & 2337 & & & FRACTURE & 280 & N. VERT & 190 & & $\mathrm{TV}$ \\
\hline 2338 & 2340 & & & FRACTURE & 180 & VERTICAL & 90 & MINERALIZED & $\mathrm{TV}$ \\
\hline 2340 & 2340 & & & FRACTURE & 270 & N. VERT & 180 & & TV \\
\hline
\end{tabular}


\& TABLE 11. SUMMARY OF INFORMATION FROM LITHOLOGIC (L), TELEVISION (TV), ACOUSTIC TELEVIEWER (AT), CALIPER (C), AND TEMPERATURE (TEMP) LOGS FOR BOREHOLE UE-25C \#2 --Continued

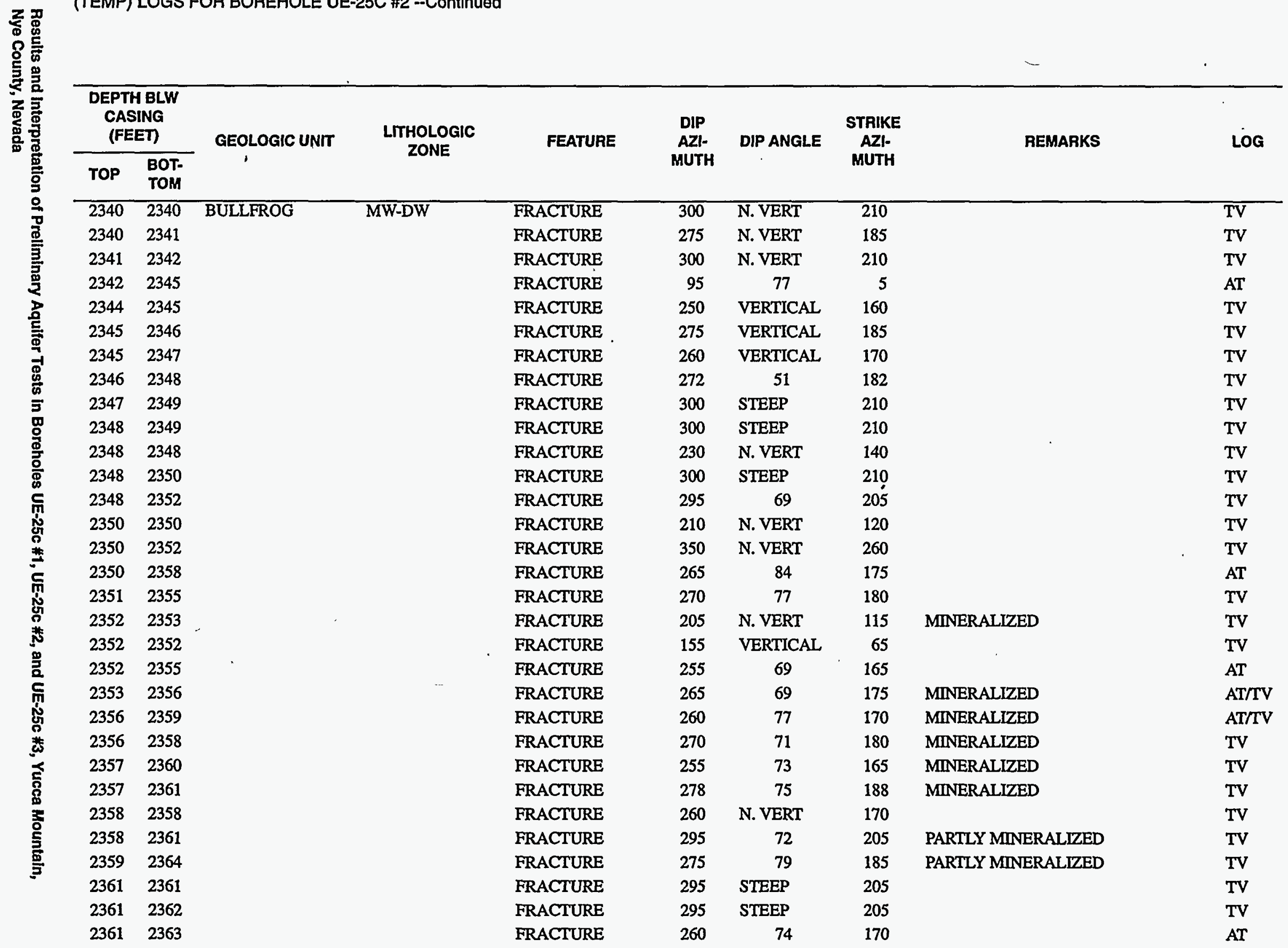


TABLE 11. SUMMARY OF INFORMATION FROM LITHOLOGIC (L), TELEVISION (TV), ACOUSTIC TELEVIEWER (AT), CALIPER (C), AND TEMPERATURE (TEMP) LOGS FOR BOREHOLE UE-25C \#2 --Continued

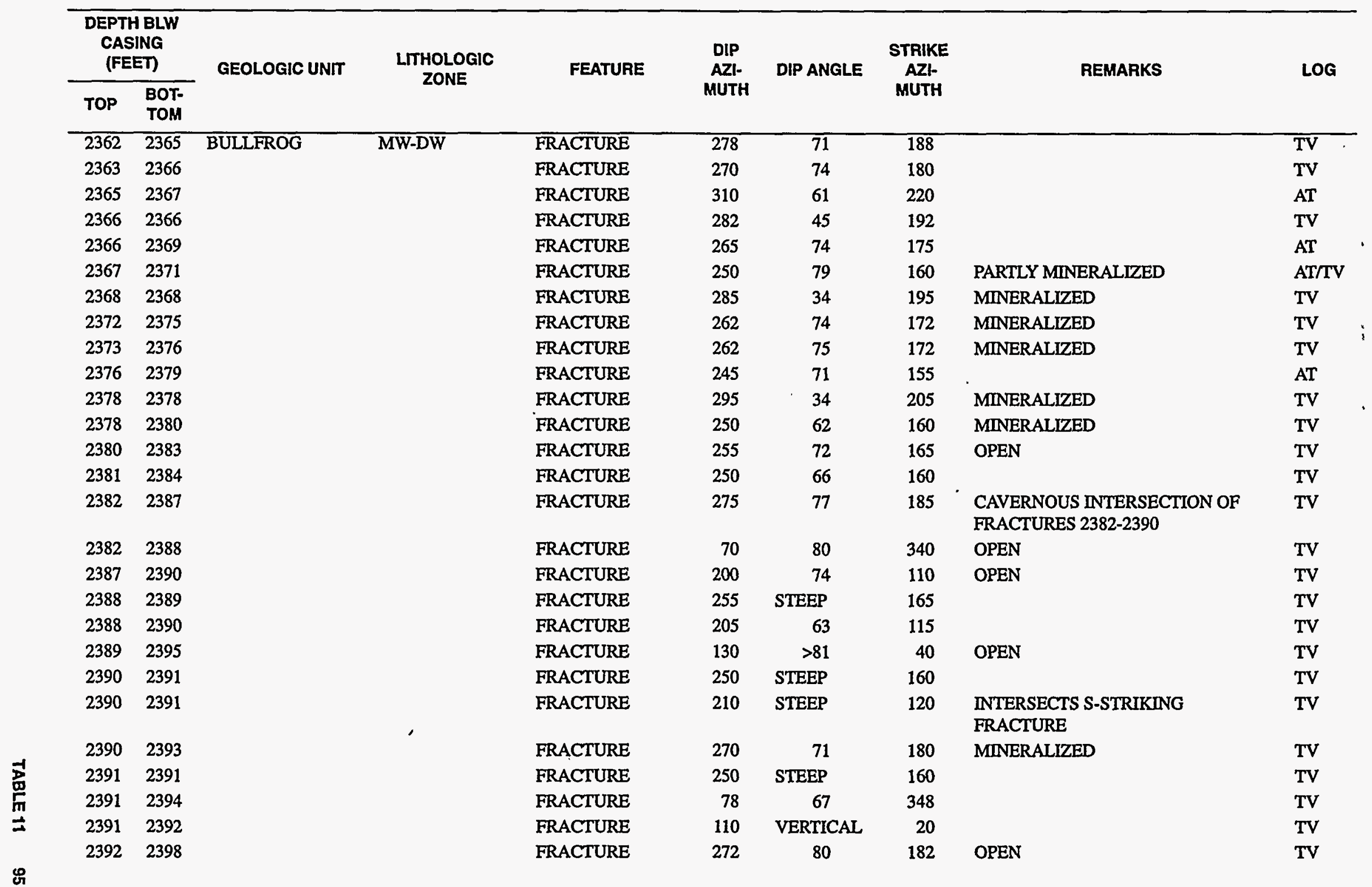


\& TABLE 11. SUMMARY OF INFORMATION FROM LITHOLOGIC (L), TELEVISION (TV), ACOUSTIC TELEVIEWER (AT), CALIPER (C), AND TEMPERATURE (TEMP) LOGS FOR BOREHOLE UE-25C \#2 --Continued

\begin{tabular}{|c|c|c|c|c|c|c|c|c|c|}
\hline \multicolumn{2}{|c|}{$\begin{array}{l}\text { DEPTH BLW } \\
\text { CASING } \\
\text { (FEET) }\end{array}$} & \multirow{2}{*}{ GEOLOGIC UNIT } & \multirow{2}{*}{$\begin{array}{l}\text { LTTHOLOGIC } \\
\text { ZONE }\end{array}$} & \multirow[t]{2}{*}{ FEATURE } & \multirow{2}{*}{$\begin{array}{c}\text { DIP } \\
\text { AZI- } \\
\text { MUTH }\end{array}$} & \multirow[t]{2}{*}{ DIP ANGLE } & \multirow{2}{*}{$\begin{array}{c}\text { STRIKE } \\
\text { AZI- } \\
\text { MUTH }\end{array}$} & \multirow[t]{2}{*}{ REMARKS } & \multirow[t]{2}{*}{ LOG } \\
\hline TOP & $\begin{array}{l}\text { BOT- } \\
\text { TOM }\end{array}$ & & & & & & & & \\
\hline 2394 & 2396 & BULLFROG & MW-DW & FRACTURE & 68 & 64 & 338 & $\begin{array}{l}\text { CAVERNOUS WHERE FRACTURES } \\
\text { INTERSECT 2394-2397 }\end{array}$ & TV \\
\hline 2395 & 2396 & & & FRACTURE & 215 & STEEP & 125 & & TV \\
\hline 2395 & 2396 & & & FRACTURE & 120 & VERTICAL & 30 & & TV \\
\hline 2396 & 2397 & & & FRACTURE & 130 & VERTICAL & 40 & & TV \\
\hline 2396 & 2396 & & & FRACTURE & 320 & 38 & 230 & & TV \\
\hline 2396 & 2397 & & & FRACTURE & 245 & 45 & 155 & & TV \\
\hline 2396 & 2397 & & & FRACTURE & 255 & N. VERT & 165 & & TV \\
\hline 2397 & 2399 & & & FRACTURE & 305 & N. VERT & 215 & OPEN & TV \\
\hline 2398 & 2403 & & & FRACTURE & 270 & 79 & 180 & OPEN & TV \\
\hline 2399 & 2404 & & & FRACTURE & 260 & 80. & 170 & & TV \\
\hline 2399 & 2405 & & & FRACTURE & 240 & 80 & 150 & & TV \\
\hline 2399 & 2401 & & & FRACTURE & 105 & VERTICAL & 15 & & $\mathrm{TV}$ \\
\hline 2402 & 2405 & & & FRACTURE & 240 & 71 & 150 & OPEN UPTOE & TV \\
\hline 2404 & 2412 & & & FRACTURE & 265 & 83 & 175 & OPEN & TV \\
\hline 2408 & 2408 & & & FRACTURE & 70 & VERTICAL & 340 & & TV \\
\hline 2408 & 2416 & & & FRACTURE & 260 & 82 & 170 & & AT \\
\hline 2410 & 2416 & & & FRACTURE & 68 & 81 & 338 & OPEN, WITH CAVITIES & TV \\
\hline 2413 & 2413 & & & FRACTURE & 100 & VERTICAL & 10 & & TV \\
\hline 2416 & 2416 & & & FRACTURE & 280 & N. VERT & 190 & & TV \\
\hline 2416 & 2417 & & & FRACTURE & 295 & STEEP & 205 & & TV \\
\hline 2417 & 2418 & & & FRACTURE & 220 & STEEP & 130 & & TV \\
\hline 2417 & 2418 & & & FRACTURE & 280 & STEEP & 190 & & TV \\
\hline 2418 & 2419 & & & FRACTURE & 270 & STEEP & 180 & & TV \\
\hline 2420 & 2421 & & & FRACTURE & 275 & 51 & 165 & & $\mathrm{AT}$ \\
\hline 2420 & 2422 & & & FRACTURE & 295 & 49 & 205 & & AT \\
\hline 2422 & 2424 & & & FRACTURE & 295 & 64 & 205 & & $\mathrm{AT}$ \\
\hline 2424 & 2426 & & & FRACTURE & 190 & N. VERT & 100 & & TV \\
\hline 2425 & 2426 & & & FRACTURE & 285 & STEEP & 195 & & TV \\
\hline 2426 & 2427 & & & FRACTURE & 250 & N. VERT & 160 & & TV \\
\hline 2427 & 2428 & & & FRACTURE & 260 & VERTICAL & 170 & & TV \\
\hline
\end{tabular}


TABLE 11. SUMMARY OF INFORMATION FROM LITHOLOGIC (L), TELEVISION (TV), ACOUSTIC TELEVIEWER (AT), CALIPER (C), AND TEMPERATURE (TEMP) LOGS FOR BOREHOLE UE-25C \#2 --Continued

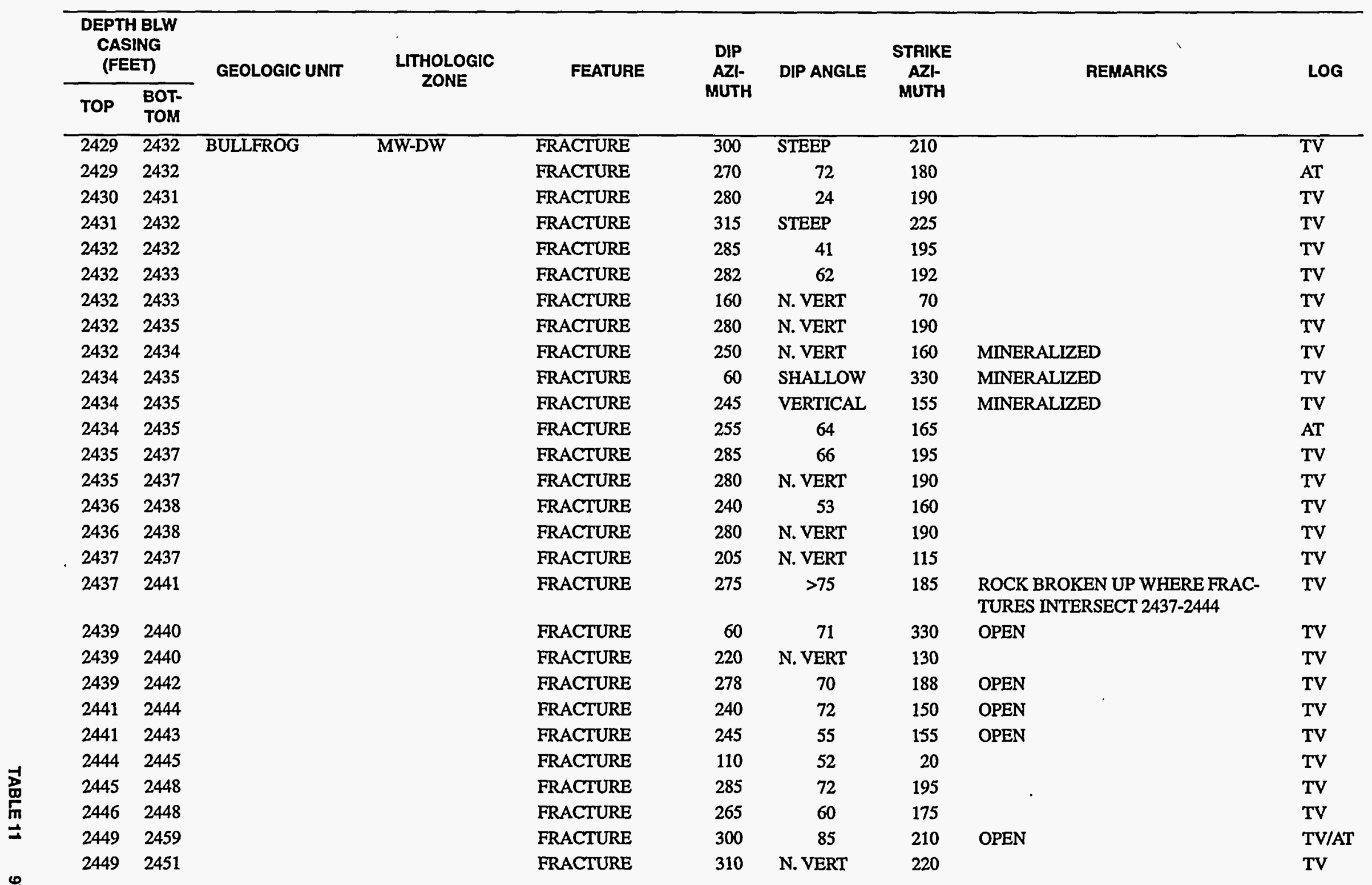


\& TABLE 11. SUMMARY OF INFORMATION FROM LITHOLOGIC (L), TELEVISION (TV), ACOUSTIC TELEVIEWER (AT), CALIPER (C), AND TEMPERATURE

\begin{tabular}{|c|c|c|c|c|c|c|c|c|c|}
\hline \multicolumn{2}{|c|}{$\begin{array}{l}\text { DEPTH BLW } \\
\text { CASING } \\
\text { (FEET) }\end{array}$} & \multirow[t]{2}{*}{ GEOLOGIC UNIT } & \multirow{2}{*}{$\begin{array}{l}\text { LITHOLOGIC } \\
\text { ZONE }\end{array}$} & \multirow[t]{2}{*}{ FEATURE } & \multirow{2}{*}{$\begin{array}{l}\text { DIP } \\
\text { AZI- } \\
\text { MUTH }\end{array}$} & \multirow[t]{2}{*}{ DIP ANGLE } & \multirow{2}{*}{$\begin{array}{c}\text { STRIKE } \\
\text { AZL- } \\
\text { MUTH }\end{array}$} & \multirow{2}{*}{ REMARKS } & \multirow[t]{2}{*}{ LOG } \\
\hline TOP & $\begin{array}{l}\text { BOT- } \\
\text { TOM }\end{array}$ & & & & & & & & \\
\hline 2451 & 2452 & BULLLFROG & MW-DW & FRACTURE & 255 & VERTICAL & 165 & $\cdot$ & TV \\
\hline 2452 & 2453 & & & FRACTURE & 265 & VERTICAL & 175 & & TV \\
\hline 2453 & 2462 & & & FRACTURE & 285 & 84 & 195 & & $\mathrm{AT}$ \\
\hline 2454 & 2455 & & & FRACTURE & 260 & VERTICAL & 170 & & TV \\
\hline 2456 & 2457 & & & FRACTURE & 260 & VERTICAL & 170 & & TV \\
\hline 2460 & & BULLFROG & PW-NW & CONTACT & & & & & $\mathbf{L}$ \\
\hline 2470 & 2473 & & & FRACTURE & 270 & $>74$ & 180 & MINERALIZED & TV \\
\hline 2473 & 2477 & & & FRACTURE & 268 & 78 & 178 & OPEN & TV \\
\hline 2473 & 2479 & & & FRACTURE & 320 & 81 & 230 & OPEN & TV \\
\hline 2475 & 2476 & & & FRACTURE & 110 & 24 & 20 & & TV \\
\hline 2478 & 2483 & & & FRACTURE & 300 & 80 & 210 & & $\mathrm{AT}$ \\
\hline 2489 & 2489 & & & FRACTURE & 240 & VERTICAL & 150 & & TV \\
\hline 2492 & 2492 & & & FRACTURE & 195 & VERTICAL & 105 & & TV \\
\hline 2492 & 2492 & & & FRACTURE & 160 & N. VERT & 70 & & TV \\
\hline 2495 & 2499 & & & FRACTURE & 250 & $>75$ & 160 & & TV \\
\hline 2499 & 2500 & & & FRACTURE & 270 & VERTICAL & 180 & MINERALIZED & TV \\
\hline 2500 & 2500 & & & FRACTURE & 260 & VERTICAL & 170 & MINERALIZED & TV \\
\hline 2506 & 2506 & & & FRACTURE & 300 & VERTICAL & 210 & MINERALIZED & TV \\
\hline 2510 & 2517 & & & FRACTURE & 258 & 82 & 168 & MINERALIZED & TV \\
\hline 2530 & 2534 & & & FRACTURE & UNK & VERTICAL & UNK & & TV \\
\hline 2532 & 2533 & & & FRACTURE & 255 & VERTICAL & 165 & & TV \\
\hline 2539 & 2544 & & & FRACTURE & 280 & $>80$ & 190 & & TV \\
\hline 2539 & 2548 & & & FRACTURE & 280 & $>84$ & 190 & & $\mathrm{TV}$ \\
\hline 2548 & 2551 & & & FRACTURE & 92 & 68 & 2 & & TV \\
\hline 2555 & 2556 & & & FRACTURE & 270 & VERTICAL & 180 & MINERALIZED & TV \\
\hline 2556 & 2560 & & & FRACTURE & 268 & 75 & 178 & MINERALIZED & TV \\
\hline 2558 & 2559 & & & FRACTURE & 245 & VERTICAL & 155 & MINERAIIZED & TV \\
\hline 2561 & 2562 & & & FRACTURE & 145 & 46 & 55 & MINERALIZED & TV \\
\hline 2561 & 2561 & & & FRACTURE & 135 & 17 & 45 & MINERALIZED & TV \\
\hline
\end{tabular}


TABLE 11. SUMMARY OF INFORMATION FROM LITHOLOGIC (L), TELEVISION (TV), ACOUSTIC TELEVIEWER (AT), CALIPER (C), AND TEMPERATURE (TEMP) LOGS FOR BOREHOLE UE-25C \#2 -Continued

\begin{tabular}{|c|c|c|c|c|c|c|c|c|c|}
\hline \multicolumn{2}{|c|}{$\begin{array}{l}\text { DEPTH BLW } \\
\text { CASING } \\
\text { (FEET) }\end{array}$} & \multirow[t]{2}{*}{ GEOLOGIC UNIT } & \multirow{2}{*}{$\begin{array}{l}\text { LITHOLOGIC } \\
\text { ZONE }\end{array}$} & \multirow[t]{2}{*}{ FEATURE } & \multirow{2}{*}{$\begin{array}{c}\text { DIP } \\
\text { AZI- } \\
\text { MUTH }\end{array}$} & \multirow[t]{2}{*}{ DIP ANGLE } & \multirow{2}{*}{$\begin{array}{c}\text { STRIKE } \\
\text { AZI- } \\
\text { MUTH }\end{array}$} & \multirow[t]{2}{*}{ REMARKS } & \multirow[t]{2}{*}{ LOG } \\
\hline TOP & $\begin{array}{l}\text { BOT- } \\
\text { TOM }\end{array}$ & & & & & & & & \\
\hline 2662 & 2663 & & & FRACTURE & 8 & 36 & 278 & MINERALIZED & TV \\
\hline 2663 & 2663 & & & FRACTURE & 5 & 32 & 275 & MINERALIZED & $\mathrm{TV}$ \\
\hline 2675 & & BULLFROG & BEDDED & CONTACT & & & & & $\mathbf{L}$ \\
\hline 2686 & 2691 & & & FRACTURE & 245 & $>81$ & 155 & MINERALIZED & TV \\
\hline 2691 & 2694 & & & FAULT & 280 & $75-90$ & 190 & PARTLY MINERALIZED & $\mathrm{TV} / \mathrm{L}$ \\
\hline 2704 & 2705 & & & FRACTURE & 255 & 32 & 165 & MINERALIZED & TV \\
\hline 2706 & 2706 & & & FRACTURE & 115 & STEEP & 25 & MINERALIZED & TV \\
\hline 2707 & 2708 & & & FRACTURE & 325 & VERTICAL & 235 & & TV \\
\hline 2710 & 2710 & & & FRACTURE & 335 & STEEP & 245 & & $\mathrm{TV}$ \\
\hline 2710 & 2710 & & & FRACTURE & 210 & STEEP & 120 & & TV \\
\hline 2710 & 2713 & & & FRACTURE & 260 & 70 & 170 & OPEN & $\mathrm{TV}$ \\
\hline 2712 & 2713 & & & FRACTURE & 215 & STEEP & 125 & & TV \\
\hline 2712 & 2713 & & & FRACTURE & 325 & STEEP & 235 & OPEN & TV \\
\hline 2713 & 2719 & & & FRACTURE & 260 & 78 & 170 & OPEN & TV/C \\
\hline 2714 & 2715 & & & FRACTURE & 150 & N. VERT & 60 & & TV \\
\hline 2717 & 2717 & & & FRACTURE & 25 & VERTICAL & 295 & & TV \\
\hline 2717 & 2718 & & & FRACTURE & 205 & N. VERT & 115 & OPEN & TV \\
\hline 2717 & 2723 & & & FRACTURE & 250 & 77 & 160 & OPEN & TV \\
\hline 2718 & 2718 & & & FRACTURE & 210 & STEEP & 120 & OPEN & TV \\
\hline 2718 & 2719 & & . & FRACTURE & 0 & VERTICAL & 270 & & TV \\
\hline
\end{tabular}


TABLE 11. SUMMARY OF INFORMATION FROM LITHOLOGIC (L), TELEVISION (TV), ACOUSTIC TELEVIEWER (AT), CALIPER (C), AND TEMPERATURE (TEMP) LOGS FOR BOREHOLE UE-25C \#2 --Continued

DEPTH BLW
CASING
(FEET) (20)

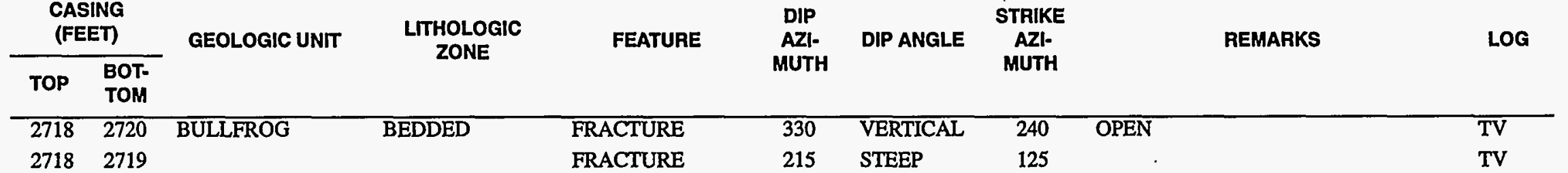

$2718 \quad 2719$

UPPER (NW-PW) CONTACT

$\begin{array}{ll}2719 & \\ 2720 & 2724\end{array}$

$2722 \quad 2725$

$\begin{array}{ll}2722 & 2726\end{array}$

\begin{tabular}{ll}
$2728 \quad 2729$ \\
\hline
\end{tabular}

$2729 \quad 2729$

$2730 \quad 2732$

\begin{tabular}{ll}
$2731 \quad 2732$ \\
\hline
\end{tabular}

$\begin{array}{ll}2732 & 2732\end{array}$

$\begin{array}{ll}2732 & 2733\end{array}$

$\begin{array}{ll}2733 & 2733\end{array}$

$2733 \quad 2734$

$\begin{array}{ll}2734 & 2735\end{array}$

$2734 \quad 2735$

$2734 \quad 2739$

\begin{tabular}{l}
$2736 \quad 2738$ \\
\hline
\end{tabular}

$\begin{array}{ll}2737 & 2741\end{array}$

$2739 \quad 2740$

$2739 \quad 2744$

$2749 \quad 2751$

$2751 \quad 2754$

$2752 \quad 2752$

$2752 \quad 2754$

$2754 \quad 2755$

$2755 \quad 2759$

$\begin{array}{ll}2757 & 2757\end{array}$

$2757 \quad 2758$

$\begin{array}{ll}2757 & 2761\end{array}$

$\begin{array}{lrrrrl}\text { CONTACT } & & & & \text { L } \\ \text { FRACTURE } & 272 & 72 & 182 & \text { OPEN } & \text { TV } \\ \text { FRACTURE } & 250 & 70 & 160 & \text { OPEN } & \text { TV/C } \\ \text { FRACTURE } & 285 & 74 & 195 & & \text { TV/C } \\ \text { FRACTURE } & 285 & 47 & 195 & & \text { AT } \\ \text { FRACTURE } & 105 & \text { N. VERT } & 15 & & \text { TV } \\ \text { FRACTURE } & 282 & 64 & 192 & & \text { TV } \\ \text { FRACTURE } & 100 & \text { VERTICAL } & 10 & & \text { TV } \\ \text { FRACTURE } & 0 & \text { VERTICAL } & 270 & & \text { TV } \\ \text { FRACTURE } & 110 & \text { SHALLOW } & 20 & & \text { TV } \\ \text { FRACTURE } & 105 & \text { SHALLOW } & 15 & \text { MINERALIZED } & \text { TV } \\ \text { FRACTURE } & 95 & \text { SHALLOW } & 5 & & \text { TV } \\ \text { FRACTURE } & 240 & 58 & 150 & & \text { TV } \\ \text { FRACTURE } & 250 & 62 & 160 & & \text { TV } \\ \text { FRACTURE } & 245 & 79 & 155 & & \text { TV } \\ \text { FRACTURE } & 90 & >64 & 0 & & \text { TV } \\ \text { FRACTURE } & 278 & 77 & 188 & & \text { TV } \\ \text { FRACTURE } & 280 & \text { N. VERT } & 190 & & \text { TV } \\ \text { FRACTURE } & 245 & 79 & 155 & & \text { AT } \\ \text { FRACTURE } & 90 & 62 & 0 & & \text { TV } \\ \text { FRACTURE } & 92 & 72 & 2 & \text { OPEN } & \text { TV } \\ \text { FRACTURE } & 275 & \text { N. VERT } & 185 & & \text { TV } \\ \text { FRACTURE } & 265 & 66 & 175 & \text { OPEN } & \text { TV } \\ \text { FRACTURE } & 115 & \text { N. VERT } & 25 & & \text { TV } \\ \text { FRACTURE } & 90 & >78 & 0 & \text { OPEN } & \text { TV } \\ \text { FRACTURE } & 255 & \text { VERTICAL } & 165 & & \text { TV } \\ \text { FRACTURE } & 265 & \text { VERTICAL } & 175 & & \text { TV } \\ \text { FRACTURE } & 115 & 76 & 25 & & \text { AT }\end{array}$


TABLE 11. SUMMARY OF INFORMATION FROM LITHOLOGIC (L), TELEVISION (TV), ACOUSTIC TELEVIEWER (AT), CALIPER (C), AND TEMPERATURE (TEMP) LOGS FOR BOREHOLE UE-25C \#2 -Continued

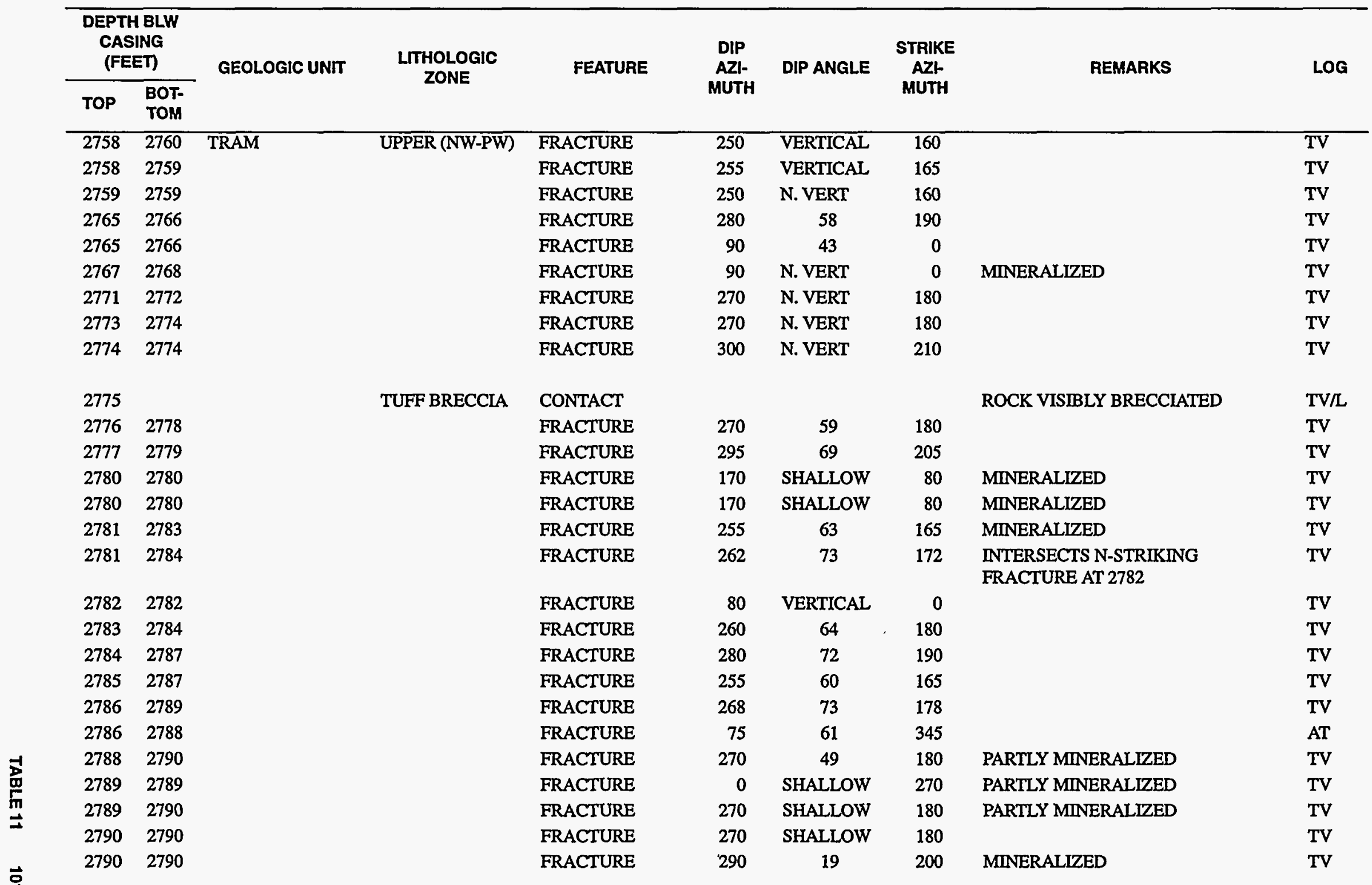




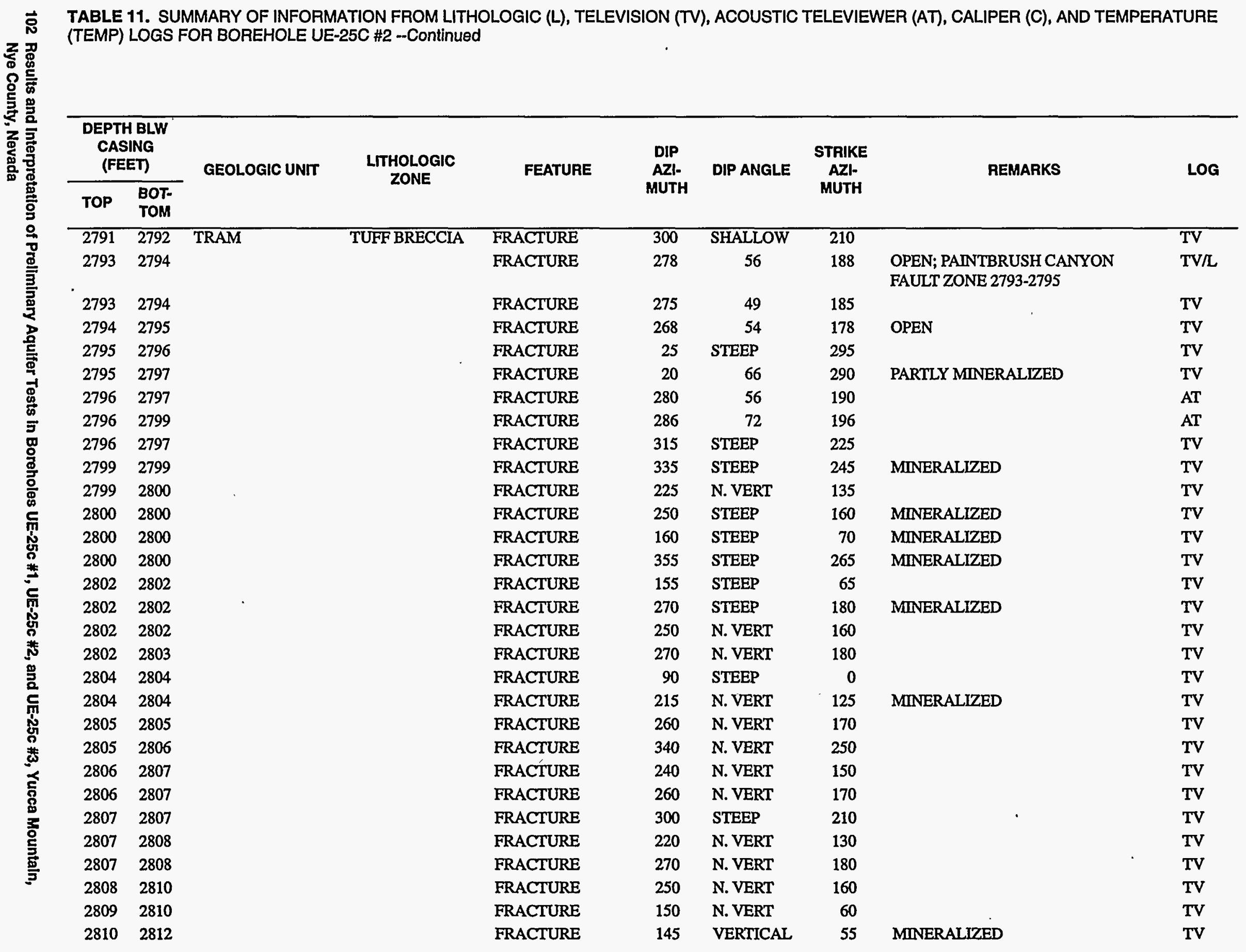


TABLE 11. SUMMARY OF INFORMATION FROM LITHOLOGIC (L), TELEVISION (TV), ACOUSTIC TELEVIEWER (AT), CALIPER (C), AND TEMPERATURE (TEMP) LOGS FOR BOREHOLE UE-25C \#2 -Continued

\begin{tabular}{|c|c|c|c|c|c|c|c|c|c|}
\hline \multicolumn{2}{|c|}{$\begin{array}{l}\text { DEPTH BLW } \\
\text { CASING } \\
\text { (FEET) }\end{array}$} & \multirow[t]{2}{*}{ GEOLOGIC UNIT } & \multirow{2}{*}{$\begin{array}{l}\text { LITHOLOGIC } \\
\text { ZONE }\end{array}$} & \multirow[t]{2}{*}{ FEATURE } & \multirow{2}{*}{$\begin{array}{c}\text { DIP } \\
\text { AZI- } \\
\text { MUTH }\end{array}$} & \multirow[t]{2}{*}{ DIP ANGLE } & \multirow{2}{*}{$\begin{array}{c}\text { STRIKE } \\
\text { AZI- } \\
\text { MUTH }\end{array}$} & \multirow[t]{2}{*}{ REMARKS } & \multirow[t]{2}{*}{ LOG } \\
\hline TOP & $\begin{array}{l}\text { BOT- } \\
\text { TOM }\end{array}$ & & & & & & & & \\
\hline 2811 & 2812 & & & FRACTURE & 295 & SHALLOW & 205 & MINERALIZED & TV \\
\hline 2812 & 2813 & & & FRACTURE & 70 & 49 & 340 & MINERALIZED & TV \\
\hline 2813 & 2814 & & & FRACTURE & 270 & VERTICAL & 180 & MINERALIZED & TV \\
\hline 2815 & 2816 & & & FRACTURE & 270 & STEEP & 180 & & TV \\
\hline 2816 & 2816 & & & FRACTURE & 255 & N. VERT & 165 & & TV \\
\hline 2818 & 2818 & & & FRACTURE & 295 & SHALLOW & 205 & MINERALIZED & TV \\
\hline 2821 & 2822 & & & FRACTURE & 270 & N. VERT & 180 & & TV \\
\hline 2822 & 2822 & & & FRACTURE & 270 & N. VERT & 180 & & TV \\
\hline 2822 & 2822 & & & FRACTURE & 270 & N. VERT & 180 & & TV \\
\hline 2824 & 2825 & & & FRACTURE & 270 & N. VERT & 180 & & $\mathrm{TV}$ \\
\hline 2824 & 2825 & & & FRACTURE & 345 & SHALLOW & 255 & MINERALIZED & TV \\
\hline 2824 & 2825 & & & FRACTURE & 350 & 49 & 260 & MINERALIZED & TV \\
\hline 2825 & 2826 & & & FRACTURE & 340 & SHALLOW & 250 & & TV \\
\hline 2825 & 2826 & & & FRACTURE & 175 & SHALLOW & 85 & MINERALIZED & TV \\
\hline 2826 & 2826 & & & FRACTURE & 135 & STEEP & 45 & & $\mathrm{TV}$ \\
\hline 2826 & 2826 & & & FRACTURE & 300 & N. VERT & 210 & MINERALIZED & TV \\
\hline 2826 & 2827 & & & FRACTURE & 340 & STEEP & 250 & MINERALIZED & TV \\
\hline 2828 & 2829 & & & FRACTURE & 310 & 64 & 220 & & TV \\
\hline 2833 & 2833 & & & FRACTURE & 90 & VERTICAL & 0 & & TV \\
\hline 2833 & 2834 & & & FRACTURE & 35 & N. VERT & 305 & & TV \\
\hline 2834 & 2835 & & & FRACTURE & 100 & N. VERT & 10 & & TV \\
\hline
\end{tabular}


TABLE 11. SUMMARY OF INFORMATION FROM LITHOLOGIC (L), TELEVISION (TV), ACOUSTIC TELEVIEWER (AT), CALIPER (C), AND TEMPERATURE (TEMP) LOGS FOR BOREHOLE UE-25C \#2 -Continued

\begin{tabular}{|c|c|c|c|c|c|c|c|c|c|}
\hline \multicolumn{2}{|c|}{$\begin{array}{l}\text { DEPTH BLW } \\
\text { CASING } \\
\text { (FEET) }\end{array}$} & \multirow[t]{2}{*}{ GEOLOGIC UNIT } & \multirow{2}{*}{$\begin{array}{l}\text { LITHOLOGIC } \\
\text { ZONE }\end{array}$} & \multirow[t]{2}{*}{ FEATURE } & \multirow{2}{*}{$\begin{array}{c}\text { DIP } \\
\text { AZI- } \\
\text { MUTH }\end{array}$} & \multirow[t]{2}{*}{ DIP ANGLE } & \multirow{2}{*}{$\begin{array}{c}\text { STRIKE } \\
\text { AZI- } \\
\text { MUTH }\end{array}$} & \multirow[t]{2}{*}{ REMARKS } & \multirow[t]{2}{*}{ LOG } \\
\hline TOP & $\begin{array}{l}\text { BOT- } \\
\text { TOM }\end{array}$ & & & & & & & & \\
\hline 2840 & 2842 & TRAM & TUFF BRECCIA & FRACTURE & 80 & VERTICAL & 350 & & TV \\
\hline 2840 & 2841 & & & FRACTURE & 325 & N. VERT & 235 & & TV \\
\hline 2841 & 2842 & & & FRACTURE & 335 & VERTICAL & 245 & & TV \\
\hline 2842 & 2842 & & & FRACTURE & 120 & SHALLOW & 30 & & TV \\
\hline 2843 & 2843 & & & FRACTURE & 90 & VERTICAL & 0 & & TV \\
\hline 2844 & 2844 & & & FRACTURE & 80 & VERTICAL & 350 & & TV \\
\hline 2845 & 2847 & & & FRACTURE & $\mathbf{0}$ & 65 & 270 & MINERALIZED & TV \\
\hline 2861 & 2862 & & & FRACTURE & 235 & STEEP & 145 & & TV \\
\hline 2868 & 2869 & & & FRACTURE & 120 & N. VERT & 30 & MINERALIZED & TV \\
\hline 2873 & 2875 & & & FRACTURE & 275 & $61-65$ & 185 & & TV \\
\hline 2874 & 2875 & & & FRACTURE & 292 & 54 & 202 & & TV \\
\hline 2874 & 2876 & & & FRACTURE & .290 & 60 & 200 & & TV \\
\hline 2875 & 2876 & & & FRACTURE & 285 & 30 & 195 & & TV \\
\hline 2876 & 2876 & & & FRACTURE & 285 & 25 & 195 & & TV \\
\hline 2877 & 2878 & & & FRACTURE & 355 & N. VERT & 265 & & TV \\
\hline 2880 & 2880 & & & FRACTURE & 345 & N. VERT & 255 & & TV \\
\hline 2881 & 2882 & & & FRACTURE & 310 & N. VERT & 220 & & $\mathrm{TV}$ \\
\hline 2881 & 2882 & & & FRACTURE & 270 & N. VERT & 180 & & TV \\
\hline 2882 & 2883 & & & FRACTURE & 355 & N. VERT & 265 & & TV \\
\hline 2882 & 2883 & & & FRACTURE & 275 & N. VERT & 185 & & TV \\
\hline 2882 & 2883 & & & FRACTURE & 340 & N. VERT & 250 & & TV \\
\hline 2883 & 2883 & & & FRACTURE & 300 & 34 & 210 & & TV \\
\hline 2883 & 2884 & & & FRACTURE & 70 & 54 & 340 & & TV \\
\hline 2884 & 2884 & & & FRACTURE & 300 & SHALLOW & 210 & & TV \\
\hline 2884 & 2884 & & & FRACTURE & 70 & STEEP & 340 & & TV \\
\hline 2884 & 2884 & & & FRACTURE & 155 & 34 & 65 & & TV \\
\hline 2884 & 2885 & & & FRACTURE & 125 & STEEP & 35 & & TV \\
\hline 2885 & 2885 & & & FRACTURE & 225 & SHALLOW & 135 & & TV \\
\hline 2886 & 2887 & & & FRACTURE & 255 & N. VERT & 165 & & TV \\
\hline 2888 & 2889 & & & FRACTURE & 326 & 59 & 236 & & $\mathrm{AT}$ \\
\hline 2888 & 2888 & & & FRACTURE & 115 & 30 & 25 & & TV \\
\hline
\end{tabular}


TABLE 11. SUMMARY OF INFORMATION FROM LITHOLOGIC (L), TELEVISION (TV), ACOUSTIC TELEVIEWER (AT), CALIPER (C), AND TEMPERATURE (TEMP) LOGS FOR BOREHOLE UE-25C \#2 -Continued

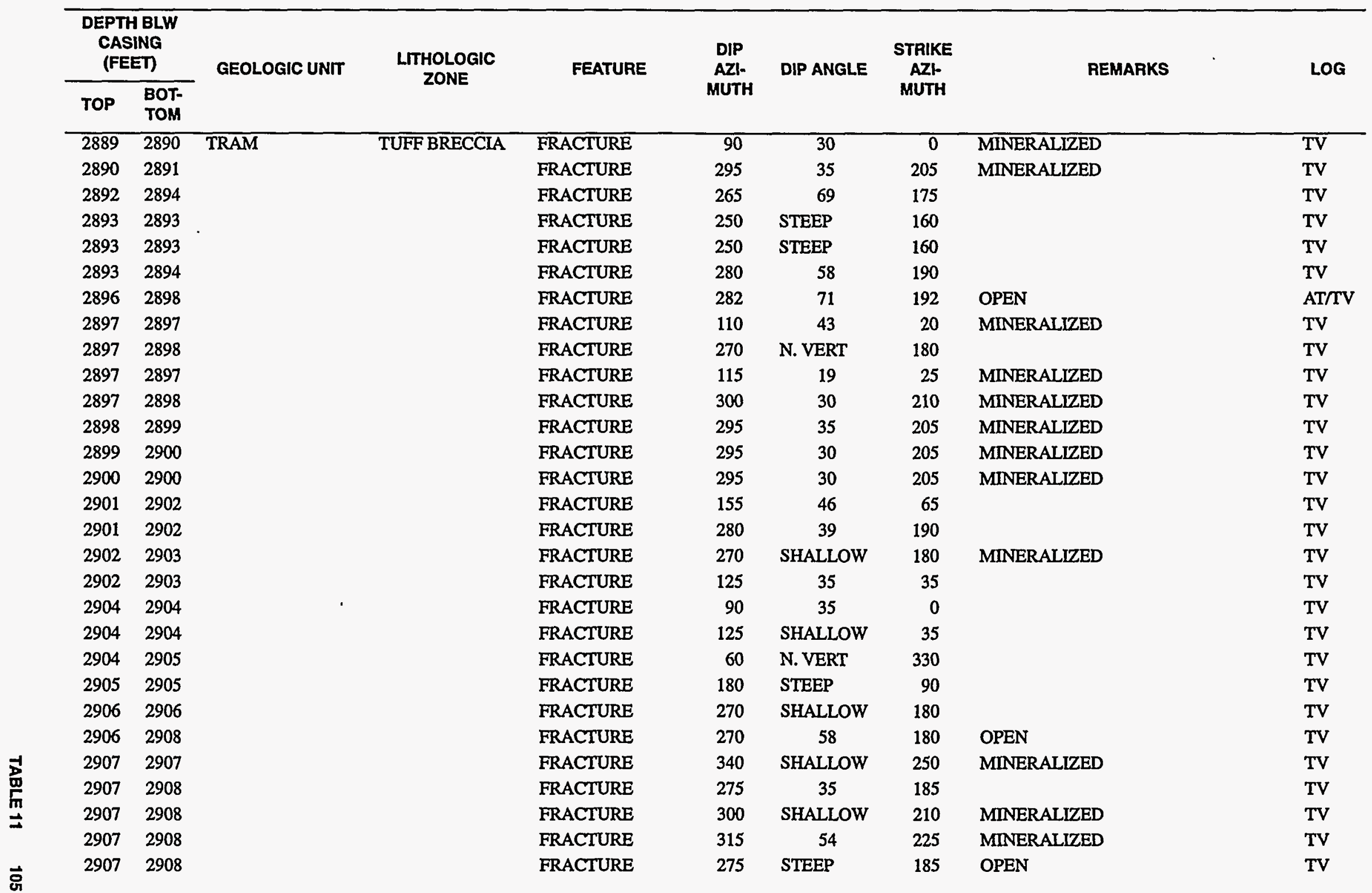


TABLE 11. SUMMARY OF INFORMATION FROM LITHOLOGIC (L), TELEVISION (TV), ACOUSTIC TELEVIEWER (AT), CALIPER (C), AND TEMPERATURE (TEMP) LOGS FOR BOREHOLE UE-25C \#2 --Continued

\begin{tabular}{|c|c|c|c|c|c|c|c|c|c|}
\hline \multicolumn{2}{|c|}{$\begin{array}{l}\text { DEPTH BLW } \\
\text { CASING } \\
\text { (FEET) }\end{array}$} & \multirow[t]{2}{*}{ GEOLOGIC UNIT } & \multirow{2}{*}{$\begin{array}{l}\text { LTHOLLOGIC } \\
\text { ZONE }\end{array}$} & \multirow[t]{2}{*}{ FEATURE } & \multirow{2}{*}{$\begin{array}{c}\text { DIP } \\
\text { AZI- } \\
\text { MUTH }\end{array}$} & \multirow[t]{2}{*}{ DIP ANGLE } & \multirow{2}{*}{$\begin{array}{c}\text { STRIKE } \\
\text { AZI- } \\
\text { MUTH }\end{array}$} & \multirow[t]{2}{*}{ REMARKS } & \multirow[t]{2}{*}{ LOG } \\
\hline TOP & $\begin{array}{l}\text { BOT- } \\
\text { TOM }\end{array}$ & & & & & & & & \\
\hline 2908 & 2908 & TRAM & TUFF BRECCIA & FRACTURE & 322 & $\overline{46}$ & 232 & MINERALIZED & TV \\
\hline 2908 & 2909 & & & FRACTURE & 300 & 30 & 210 & & TV \\
\hline 2909 & 2909 & & & FRACTURE & 300 & 25 & 210 & & TV \\
\hline 2909 & 2909 & & & FRACTURE & 60 & SHALLOW & 330 & & TV \\
\hline 2910 & 2910 & & & FRACTURE & 315 & N. VERT & 225 & & TV \\
\hline 2910 & 2910 & & & FRACTURE & 355 & N. VERT & 265 & MINERALIZED & TV \\
\hline 2910 & 2910 & & & FRACTURE & 300 & SHALLOW & 210 & MINERALIZED & TV \\
\hline 2910 & 2910 & & & FRACTURE & 30 & STEEP & 300 & MINERALIZED & TV \\
\hline 2910 & 2911 & & & FRACTURE & 345 & STEEP & 255 & MINERALIZED & TV \\
\hline 2910 & 2911 & & & FRACTURE & 285 & 54 & 195 & & $\mathrm{AT}$ \\
\hline 2910 & 2911 & & & FRACTURE & 205 & STEEP & 115 & & TV \\
\hline 2910 & 2911 & & & FAULT & 90 & VERTICAL & 0 & $\begin{array}{l}\text { OFFSETS SW-STRIKING FRACTURE } \\
\text { AT } 2911\end{array}$ & TV \\
\hline 2911 & 2911 & & & FRACTURE & 300 & SHALLOW & 210 & OFFSET BY FAULT & TV \\
\hline 2912 & 2913 & & & FRACTURE & 30 & N. VERT & 300 & MINERALIZED & TV \\
\hline 2912 & 2913 & & & FRACTURE & 45 & STEEP & 315 & & TV \\
\hline 2912 & 2914 & & & FRACTURE & 5 & 52 & 275 & MINERALIZED & TV \\
\hline 2913 & 2914 & & & FR.ACTURE & 0 & 55 & 270 & MINERALIZED & TV \\
\hline 2914 & 2914 & & & FRACTURE & 255 & SHALLOW & 165 & & TV \\
\hline 2914 & 2915 & & & FRACTURE & 70 & SHALLOW & 340 & & TV \\
\hline 2914 & 2914 & & & FRACTURE & 200 & SHALLOW & 110 & & TV \\
\hline 2914 & 2915 & & & FRACTURE & 100 & SHALLOW & 10 & & TV \\
\hline 2915 & 2916 & & & FRACTURE & 195 & SHALLOW & 105 & MINERALIZED & TV \\
\hline 2916 & 2917 & & & FRACTURE & 50 & 55 & 320 & MINERALIZED & TV \\
\hline 2918 & 2919 & & & FRACTURE & 10 & 57 & 280 & & TV \\
\hline 2919 & 2920 & & & FRACTURE & 2 & 25 & 272 & MINERALIZED & TV \\
\hline 2920 & 2920 & & & FRACTURE & 2 & 25 & 272 & MINERALIZED & TV \\
\hline 2921 & 2921 & & & FRACTURE & 105 & 25 & 15 & MINERALIZED & TV \\
\hline 2922 & 2922 & & & FRACTURE & 165 & 25 & 75 & & TV \\
\hline 2922 & 2923 & & & FRACTURE & 295 & SHALLOW & 205 & & TV \\
\hline 2923 & 2923 & & & FRACTURE & 355 & 19 & 265 & & TV \\
\hline
\end{tabular}


TABLE 11. SUMMARY OF INFORMATION FROM LITHOLOGIC (L), TELEVISION (TV), ACOUSTIC TELEVIEWER (AT), CALIPER (C), AND TEMPERATURE (TEMP) LOGS FOR BOREHOLE UE-25C \#2 -Continued

\begin{tabular}{|c|c|c|c|c|c|c|c|c|c|}
\hline \multicolumn{2}{|c|}{$\begin{array}{l}\text { DEPTH BLW } \\
\text { CASING } \\
\text { (FEET) }\end{array}$} & \multirow[t]{2}{*}{ GEOLOGIC UNIT } & \multirow{2}{*}{$\begin{array}{l}\text { LITHOLOGIC } \\
\text { ZONE }\end{array}$} & \multirow[t]{2}{*}{ FEATURE } & \multirow{2}{*}{$\begin{array}{c}\text { DIP } \\
\text { AZI- } \\
\text { MUTH }\end{array}$} & \multirow[t]{2}{*}{ DIP ANGLE } & \multirow{2}{*}{$\begin{array}{c}\text { STRIKE } \\
\text { AZI- } \\
\text { MUTH }\end{array}$} & \multirow[t]{2}{*}{ REMARKS } & \multirow[t]{2}{*}{ LOG } \\
\hline TOP & $\begin{array}{l}\text { BOT- } \\
\text { TOM }\end{array}$ & & & & & & & & \\
\hline 2923 & 2925 & $\overline{\text { TRAM }}$ & TUFF BRECCIA & FRACTURE & 85 & 59 & 355 & & TV \\
\hline 2923 & 2924 & & & FRACTURE & 300 & 25 & 210 & & TV \\
\hline 2924 & 2925 & & & FRACTURE & 25 & 52 & 295 & & TV \\
\hline 2925 & 2926 & & & FRACTURE & 165 & $>43$ & 75 & & TV \\
\hline 2925 & 2926 & & & FRACTURE & 55 & STEEP & 325 & & TV \\
\hline 2926 & 2926 & & & FRACTURE & 355 & 43 & 265 & & TV \\
\hline 2926 & 2927 & & & FRACTURE & 355 & 43 & 265 & & TV \\
\hline 2927 & 2928 & & & FRACTURE & 348 & 43 & 258 & & TV \\
\hline 2927 & 2929 & & & FRACTURE & 65 & 69 & 235 & OPEN & TV \\
\hline 2933 & 2933 & & & FRACTURE & 355 & 30 & 265 & & TV \\
\hline 2933 & 2934 & & & FRACTURE & 340 & 30 & 250 & & TV \\
\hline 2935 & & & LOWER (PW) & CONTACT & & & & & $\mathbf{L}$ \\
\hline 2936 & 2937 & & & FRACTURE & 325 & 35 & 235 & & TV \\
\hline 2937 & 2938 & & & FRACTURE & 165 & N. VERT & 75 & & TV \\
\hline 2939 & 2942 & & & FRACTURE & 160 & $>76$ & 70 & & TV \\
\hline 2943 & 2943 & & & FRACTURE & 300 & SHALLOW & 210 & MINERALIZED & TV \\
\hline 2945 & 2946 & & & FRACTURE & 340 & VERTICAL & 255 & & TV \\
\hline 2946 & 2946 & & & FRACTURE & 260 & 25 & 170 & & TV \\
\hline 2960 & 2961 & & & FRACTURE & 265 & 25 & 175 & OPEN & TV \\
\hline 2986 & & & & BOTTOM & & & & $\begin{array}{l}\text { HOLE CAVED TO ORIGINAL TD AT } \\
3000\end{array}$ & TV \\
\hline
\end{tabular}


DABLE 12. SUMMARY OF INFORMATION FROM LITHOLOGIC (L), TELEVISION (TV), ACOUSTIC TELEVIEWER (AT), CALIPER (C), AND TEMPERATURE (TEMP) LOGS FOR BOREHOLE UE-25C \#3

[Abbreviations for tables 10,11, and 12: CSG, casing; NW, nonwelded; NW-PW, nonwelded to partially welded; MW, moderately welded; MW-DW, moderately to densely welded; PW-NW, partially welded to nonwelded; PW, partially welded; N.VERT, near vertical; LITH, lithologic; TD, total depth; N, north, S, south; SW, southwest, SE, southeast; SSW, south-southwest]

\begin{tabular}{|c|c|c|c|c|c|c|c|c|c|}
\hline \multicolumn{2}{|c|}{$\begin{array}{l}\text { DEPTH BLW } \\
\text { CASING } \\
\text { (FEET) }\end{array}$} & \multirow[t]{2}{*}{ GEOLOGIC UNIT } & \multirow{2}{*}{$\begin{array}{l}\text { LITHOLOGIC } \\
\text { ZONE }\end{array}$} & \multirow[t]{2}{*}{ FEATURE } & \multirow{2}{*}{$\begin{array}{l}\text { DIP } \\
\text { AZI- } \\
\text { MUTH }\end{array}$} & \multirow[t]{2}{*}{ DIP ANGLE } & \multirow{2}{*}{$\begin{array}{c}\text { STRIKE } \\
\text { AZI- } \\
\text { MUTH }\end{array}$} & \multirow[t]{2}{*}{ REMARKS } & \multirow[t]{2}{*}{ LOG } \\
\hline TOP & $\begin{array}{l}\text { BOT- } \\
\text { TOM }\end{array}$ & & & & & & & & \\
\hline 1316 & & CALICO HILLS & NW & WATER TABLE & & & & DEAD INSECT ON WATER SURFACE & TV \\
\hline 1320 & 1368 & & & CONCRETE & & & & $\begin{array}{l}\text { SPALLED, ROUGH; HOLE } \\
\text { ABRUPTLY ENLARGED BELOW }\end{array}$ & $\mathrm{TV} / \mathrm{C}$ \\
\hline 1370 & 1372 & & & GOUGED ZONE & & & & SPIRALED WASHOUTS & TVIAT \\
\hline 1382 & 1383 & & & CORRUGATED & & & & HORIZONTAL WASHOUTS & TV \\
\hline 1389 & 1406 & & & GOUGED ZONE & & & . & SPIRALED WASHOUTS & TVIAT \\
\hline 1413 & 1414 & & & FRACTURE & 93 & N. VERT & 3 & & TV \\
\hline 1416 & 1418 & & & CORRUGATED & & & & HORIZONTAL WASHOUTS & TV \\
\hline 1433 & 1435 & & & FRACTURE & 82 & 54 & 352 & OPEN AT UPTOE & TV \\
\hline 1444 & 1445 & & & FRACTURE & 68 & $>48$ & 338 & & TV \\
\hline 1444 & 1445 & & & FRACTURE & 310 & N. VERT & 220 & & TV \\
\hline 1445 & 1449 & & & FRACTURE & 65 & $>73$ & 335 & & TV \\
\hline 1446 & 1450 & & & FRACTURE & 58 & $>74$ & 328 & & TV \\
\hline 1483 & 1490 & & & FRACTURE & 90 & $>79$ & 0 & & TV \\
\hline 1491 & 1493 & & & FRACTURE & 90 & 51 & 0 & & TV \\
\hline 1492 & 1498 & . & & FRACTURE & 232 & 77 & 142 & OPEN AT DOWNTOE & TV \\
\hline 1493 & 1495 & & & FRACTURE & 88 & 50 & 358 & & TV \\
\hline 1493 & 1498 & & & FRACTURE & 268 & 75 & 178 & OPEN AT DOWNTOE & TV \\
\hline 1495 & 1499 & & & FRACTURE & 263 & 70 & 173 & OPEN AT DOWNTOE & TV \\
\hline 1496 & 1504 & & & FRACTURE & 75 & $>79$ & 345 & OPEN & TV \\
\hline 1499 & 1501 & & & FRACTURE & 275 & $>57$ & 185 & OPEN AT DOWNTOE & TV \\
\hline 1499 & 1502 & & & FRACTURE & 263 & 61 & 173 & OPEN AT DOWNTOE & TV \\
\hline 1505 & 1510 & & & FRACTURE & 98 & 77 & 8 & & TV \\
\hline 1512 & 1513 & & & FRACTURE & 315 & 44 & 225 & & TV \\
\hline 1513 & 1514 & & & LEDGE & & & & HOLE DIAMETER REDUCED & TV \\
\hline 1514 & 1514 & & & FRACTURE & 325 & SHALLOW & 235 & & TV \\
\hline 1516 & 1519 & & & FRACTURE & 110 & $>68$ & 20 & . & TV \\
\hline 1518 & 1520 & & & FRACTURE & 100 & N. VERT & 10 & & TV \\
\hline 1520 & 1521 & & & FRACTURE & 95 & N. VERT & 5 & & TV \\
\hline 1521 & 1522 & & & FRACTURE & UNK & N. VERT & UNK & & TV \\
\hline 1534 & 1541 & & & FRACTURE & 270 & $>82$ & 180 & & TV \\
\hline
\end{tabular}


TABLE 12. SUMMARY OF INFORMATION FROM LITHOLOGIC (L), TELEVISION (TV), ACOUSTIC TELEVIEWER (AT), CALIPER (C), AND TEMPERATURE (TEMP) LOGS FOR BOREHOLE UE-25C \#3 --Continued

\begin{tabular}{|c|c|c|c|c|c|c|c|c|c|}
\hline \multicolumn{2}{|c|}{$\begin{array}{l}\text { DEPTH BLW } \\
\text { CASING } \\
\text { (FEET) }\end{array}$} & \multirow{2}{*}{ GEOLOGIC UNTT } & \multirow{2}{*}{$\begin{array}{l}\text { LITHOLOGIC } \\
\text { ZONE }\end{array}$} & \multirow{2}{*}{ FEATURE } & \multirow{2}{*}{$\begin{array}{c}\text { DIP } \\
\text { AZt } \\
\text { MUTH }\end{array}$} & \multirow[t]{2}{*}{ DIP ANGLE } & \multirow{2}{*}{$\begin{array}{c}\text { STRIKE } \\
\text { AZI- } \\
\text { MUTH }\end{array}$} & \multirow[t]{2}{*}{ REMARKS } & \multirow[t]{2}{*}{ LOG } \\
\hline TOP & $\begin{array}{l}\text { BOT- } \\
\text { TOM }\end{array}$ & & & & & & & & \\
\hline 1543 & 1543 & & & FRACTURE & 200 & 23 & 110 & & TV \\
\hline 1552 & 1553 & & & FRACTURE & 200 & 23 & 110 & & TV \\
\hline 1581 & 1582 & & & FRACTURE & 200 & 23 & 110 & & TV \\
\hline 1581 & 1582 & & & FRACTURE & 200 & 23 & 110 & & TV \\
\hline 1582 & 1582 & & & FRACTURE & 115 & SHALLOW & 25 & & TV \\
\hline 1582 & 1584 & & & FRACTURE & 170 & 64 & 80 & & TV \\
\hline 1585 & 1586 & & & FRACTURE & 210 & 24 & 120 & & TV \\
\hline 1615 & 1618 & & & FRACTURE & 115 & 71 & 25 & $\begin{array}{l}\text { CAVERNOUS INTERSECTION WITH } \\
\text { SSW FRACTURE AT } 1616\end{array}$ & TV \\
\hline 1617 & 1617 & & & FRACTURE & 235 & 24 & 145 & & TV \\
\hline 1619 & 1620 & & & FRACTURE & 105 & 29 & 15 & & $\mathrm{AT}$ \\
\hline 1620 & 1620 & & & FRACTURE & 95 & 38 & 5 & & $\mathrm{AT}$ \\
\hline 1622 & 1623 & & & FRACTURE & 260 & N. VERT & 170 & & $\mathrm{TV}$ \\
\hline 1622 & 1625 & & & FRACTURE & 145 & $>69$ & 55 & $\begin{array}{l}\text { OPEN; HOLE ENLARGED BY } \\
\text { FRACTURES } 1622-1625\end{array}$ & TV \\
\hline 1623 & 1624 & & & FRACTURE & 2 & 37 & 272 & OPEN & TV \\
\hline 1624 & 1625 & & & FRACTURE & 95 & N. VERT & 5 & OPEN & TV \\
\hline 1624 & 1625 & & & FRACTURE & 140 & N. VERT & 50 & & TV \\
\hline 1624 & 1624 & & & FRACTURE & 280 & N. VERT & 190 & OPEN & TV \\
\hline 1624 & 1625 & & & FRACTURE & 245 & STEEP & 155 & & TV \\
\hline 1624 & 1625 & & . & FRACTURE & 255 & $>47$ & 165 & & TV \\
\hline
\end{tabular}




\begin{tabular}{|c|c|c|c|c|c|c|c|c|c|}
\hline \multicolumn{2}{|c|}{$\begin{array}{l}\text { DEPTH BLW } \\
\text { CASING } \\
\text { (FEET) }\end{array}$} & GEOLOGIC UNIT & $\begin{array}{l}\text { LTTHOLOGIC } \\
\text { ZONE }\end{array}$ & FEATURE & $\begin{array}{l}\text { DIP } \\
\text { AZI- } \\
\text { MUTH }\end{array}$ & DIP ANGLE & $\begin{array}{c}\text { STRIKE } \\
\text { AZI- } \\
\text { MUTH }\end{array}$ & REMARKS & LOG \\
\hline 1626 & 1627 & & & FRACTURE & 75 & 53 & 345 & MINERALIZED & $\mathrm{AT} / \mathrm{TV}$ \\
\hline 1628 & 1629 & & & FRACTURE & 265 & 58 & 175 & MINERALIZED & AT/TV \\
\hline 1628 & 1628 & & ' & FRACTURE & 235 & 25 & 145 & MINERALIZED & TV \\
\hline 1629 & 1630 & & & FRACTURE & 105 & 54 & 15 & OPEN & TV \\
\hline 1629 & 1631 & PROW PASS & NW-PW & CONTACT & & & & OPEN PARTING AT CONTACT & TV \\
\hline 1631 & 1631 & & & FRACTURE & 75 & 35 & 345 & $\begin{array}{l}\text { HOLE ENLARGED BY FRACTURES } \\
1631-1638\end{array}$ & TV \\
\hline 1635 & 1636 & & & FRACTURE & 325 & SHALLOW & 235 & MINERALIZED & TV \\
\hline 1638 & 1638 & & & FRACTURE & 350 & SHALLOW & 260 & MINERALIZED & TV \\
\hline 1639 & 1639 & & & FRACTURE & 25 & SHALLOW & 295 & & $\mathrm{AT}$ \\
\hline 1640 & 1640 & & & FRACTURE & 130 & 27 & 40 & & TV \\
\hline 1651 & 1652 & & & FRACTURE & 95 & SHALLOW & 5 & MINERALIZED & TV \\
\hline 1657 & 1658 & & & FRACTURE & 60 & 33 & 330 & MINERALIZED & TV \\
\hline 1666 & 1669 & & & FRACTURE & 300 & 70 & 210 & & TV \\
\hline 1668 & 1669 & & & FRACTURE & 190 & N. VERT & 100 & & TV \\
\hline 1672 & 1674 & & & FRACTURE & 265 & N. VERT & 175 & & TV \\
\hline 1750 & 1751 & & & FRACTURE & 326 & 58 & 236 & & TV \\
\hline 1751 & 1752 & $\cdot$ & & FRACTURE & 335 & $>52$ & 245 & & TV \\
\hline 1751 & 1752 & & & FRACTURE & 91 & $>50$ & 1 & & TV \\
\hline 1752 & 1752 & & & FRACTURE & 150 & STEEP & 60 & & TV \\
\hline
\end{tabular}


TABLE 12. SUMMARY OF INFORMATION FROM LITHOLOGIC (L), TELEVISION (TV), ACOUSTIC TELEVIEWER (AT), CALIPER (C), AND TEMPERATURE (TEMP) LOGS FOR BOREHOLE UE-25C \#3 --Continued

\begin{tabular}{|c|c|c|c|c|c|c|c|c|c|}
\hline \multicolumn{2}{|c|}{$\begin{array}{l}\text { DEPTH BLW } \\
\text { CASING } \\
\text { (FEET) }\end{array}$} & \multirow[t]{2}{*}{ GEOLOGIC UNIT } & \multirow{2}{*}{$\begin{array}{l}\text { LTHOLOGIC } \\
\text { ZONE }\end{array}$} & \multirow[t]{2}{*}{ FEATURE } & \multirow{2}{*}{$\begin{array}{c}\text { DIP } \\
\text { AZI- } \\
\text { MUTH }\end{array}$} & \multirow[t]{2}{*}{ DIP ANGLE } & \multirow{2}{*}{$\begin{array}{c}\text { STRIKE } \\
\text { AZł- } \\
\text { MUTH }\end{array}$} & \multirow[t]{2}{*}{ REMARKS } & \multirow[t]{2}{*}{ LOG } \\
\hline TOP & $\begin{array}{l}\text { BOT- } \\
\text { TOM }\end{array}$ & & & & & & & & \\
\hline 1779 & 1779 & PROW PASS & NW-PW & FRACTURE & 325 & N. VERT & 235 & & TV \\
\hline 1780 & & & MW & CONTACT & & & & & $\mathrm{L}$ \\
\hline 1795 & 1797 & & & FRACTURE & 260 & 68 & 170 & MINERALIZED & TV \\
\hline 1796 & 1796 & & & FRACTURE & 130 & N. VERT & 40 & & TV \\
\hline 1804 & 1806 & & & FRACTURE & 300 & 72 & 210 & & $\mathrm{AT}$ \\
\hline 1805 & 1806 & & & FRACTURE & 180 & N. VERT & 90 & & TV \\
\hline 1806 & 1807 & & & FRACTURE & 55 & $>58$ & 325 & & TV \\
\hline 1813 & 1814 & & & FRACTURE & 310 & STEEP & 220 & MINERALIZED & TV \\
\hline 1814 & 1815 & & & FRACTURE & 270 & STEEP & 180 & MINERALIZED & TV \\
\hline 1814 & 1815 & & & FRACTURE & 200 & N. VERT & 110 & MINERALIZED & TV \\
\hline 1815 & 1817 & & & FRACTURE & 285 & 66 & 195 & MINERALIZED & AT/TV \\
\hline 1820 & 1823 & & & FRACTURE & 250 & 73 & 160 & & AT \\
\hline 1825 & 1825 & & & FRACTURE & 140 & 19 & 50 & & TV \\
\hline 1825 & 1826 & & & FRACTURE & 145 & 19 & 55 & MINERALIZED & TV \\
\hline 1829 & 1830 & & & FRACTURE & 50 & 35 & 320 & & TV \\
\hline 1830 & & & PW-NW & CONTACT & & & & & $\mathrm{L}$ \\
\hline 1830 & 1831 & & & FRACTURE & 262 & N. VERT & 172 & & TV \\
\hline 1831 & 1833 & & & FRACTURE & 245 & N. VERT & 155 & & TV \\
\hline 1835 & 1835 & & & FRACTURE & 135 & $>25$ & 45 & & TV \\
\hline 1835 & 1835 & & & FRACTURE & 285 & SHALLOW & 195 & MINERALIZED & TV \\
\hline 1837 & 1839 & & & FRACTURE & 20 & $>58$ & 290 & & TV \\
\hline 1846 & 1847 & & & FRACTURE & 160 & N. VERT & 70 & & TV \\
\hline 1849 & 1852 & & & FRACTURE & 268 & 75 & 178 & & TV \\
\hline 1855 & 1860 & & & FRACTURE & . 270 & $>80$ & 180 & & TV \\
\hline 1863 & 1865 & & & FRACTURE & 245 & N. VERT & 155 & & TV \\
\hline 1938 & 1938 & & & FRACTURE & 355 & 30 & 265 & MINERALIZED & TV \\
\hline 2085 & & & BEDDED & CONTACT & & & & & $\mathbf{L}$ \\
\hline
\end{tabular}


TABLE 12. SUMMARY OF INFORMATION FROM LITHOLOGIC (L), TELEVISION (TV), ACOUSTIC TELEVIEWER (AT), CALIPER (C), AND TEMPERATURE (TEMP) LOGS FOR BOREHOLE UE-25C \#3 --Continued

\begin{tabular}{|c|c|c|c|c|c|c|c|c|c|}
\hline \multicolumn{2}{|c|}{$\begin{array}{l}\text { DEPTH BLW } \\
\text { CASING } \\
\text { (FEET) }\end{array}$} & \multirow{2}{*}{ GEOLOGIC UNIT } & \multirow{2}{*}{$\begin{array}{l}\text { LITHOLOGIC } \\
\text { ZONE }\end{array}$} & \multirow{2}{*}{ FEATURE } & \multirow{2}{*}{$\begin{array}{l}\text { DIP } \\
\text { AZI- } \\
\text { MUTH }\end{array}$} & \multirow{2}{*}{ DIP ANGLE } & \multirow{2}{*}{$\begin{array}{c}\text { STRIKE } \\
\text { AZI- } \\
\text { MUTH }\end{array}$} & \multirow{2}{*}{ REMARKS } & \multirow{2}{*}{ LOG } \\
\hline TOP & $\begin{array}{l}\text { BOT- } \\
\text { TOM }\end{array}$ & & & & & & & & \\
\hline 2112 & & BULLFROG & NW-PW & CONTACT & & & & TEXTURE BECOMES COARSER & TV/L \\
\hline 2116 & 2117 & & & FRACTURE & 350 & 23 & 260 & & TV \\
\hline 2116 & 2117 & & & FRACTURE & 350 & 23 & 260 & & $\mathrm{TV}$ \\
\hline 2117 & 2117 & & & FRACTURE & 350 & 18 & 260 & & TV \\
\hline 2117 & 2117 & & & FRACTURE & 350 & 24 & 260 & & TV \\
\hline 2117 & 2118 & & & FRACTURE & 350 & 24 & 260 & & TV \\
\hline 2118 & 2118 & & & FRACTURE & 350 & 38 & 260 & & TV \\
\hline 2119 & 2119 & & & FRACTURE & 350 & 29 & 260 & & TV \\
\hline 2119 & 2119 & & & FRACTURE & 350 & 24 & 260 & & TV \\
\hline 2120 & 2120 & & & FRACTURE & 350 & 24 & 260 & & TV \\
\hline 2120 & 2121 & & & FRACTURE & 350 & 29 & 260 & & TV \\
\hline 2121 & 2121 & & & FRACTURE & 350 & 24 & 260 & & TV \\
\hline 2122 & 2123 & & & FRACTURE & 345 & 18 & 255 & & TV \\
\hline 2123 & 2124 & & & FRACTURE & 345 & 29 & 255 & & TV \\
\hline 2124 & 2125 & & & FRACTURE & 345 & 38 & 255 & & TV \\
\hline 2125 & 2125 & & & FRACTURE & 345 & 24 & 255 & & TV \\
\hline 2126 & 2126 & & & FRACTURE & 345 & 29 & 255 & MINERALIZED & TV \\
\hline 2128 & 2129 & & & FRACTURE & 275 & 29 & 185 & MINERALIZED & TV \\
\hline 2128 & 2129 & & & FRACTURE & 110 & 48 & 20 & MINERALIZED & TV \\
\hline 2128 & 2129 & & & FRACTURE & 345 & 38 & 255 & MINERALIZED & TV \\
\hline 2129 & 2130 & & & FRACTURE & 290 & N. VERT & 200 & & TV \\
\hline 2129 & 2130 & & & FRACTURE & 285 & N. VERT & 195 & & TV \\
\hline 2130 & 2131 & & & FRACTURE & 275 & N. VERT & 185 & & TV \\
\hline 2130 & 2132 & & & FRACTURE & 285 & 64 & 195 & & TV \\
\hline 2143 & 2147 & & & FRACTURE & 245 & $>77$ & 155 & & TV \\
\hline 2174 & 2177 & & & FRACTURE & 270 & 75 & 180 & MINERALIZED & TV \\
\hline 2210 & & BULLFROG & MW-DW & CONTACT & & & & & L \\
\hline 2258 & 2268 & & & FRACTURE & 280 & 85 & 190 & MINERALIZED & $\mathrm{AT} / \mathrm{TV}$ \\
\hline 2263 & 2269 & & & FRACTURE & $275^{\circ}$ & 82 & 185 & MINERALIZED & $\mathrm{AT} / \mathrm{TV}$ \\
\hline 2267 & 2271 & & & FRACTURE & 285 & 76 & 195 & MINERALIZED & $\mathrm{AT} / \mathrm{TV}$ \\
\hline 2286 & 2292 & & & FRACTURE & 260 & 81 & 170 & MINERALIZED & $\mathrm{AT} / \mathrm{TV}$ \\
\hline
\end{tabular}


TABLE 12. SUMMARY OF INFORMATION FROM LITHOLOGIC (L), TELEVISION (TV), ACOUSTIC TELEVIEWER (AT), CALIPER (C), AND TEMPERATURE (TEMP) LOGS FOR BOREHOLE UE-25C \#3 --Continued

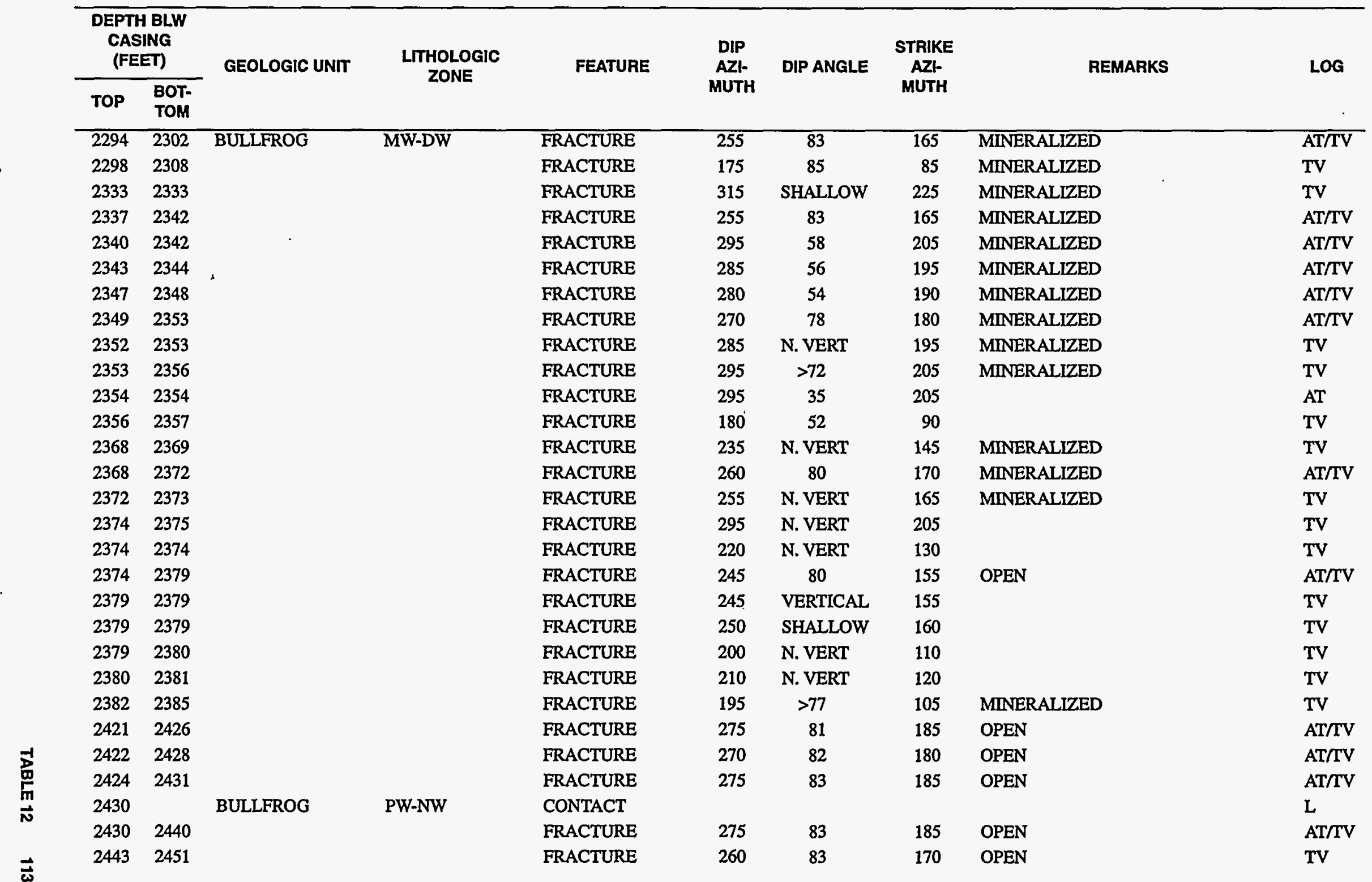




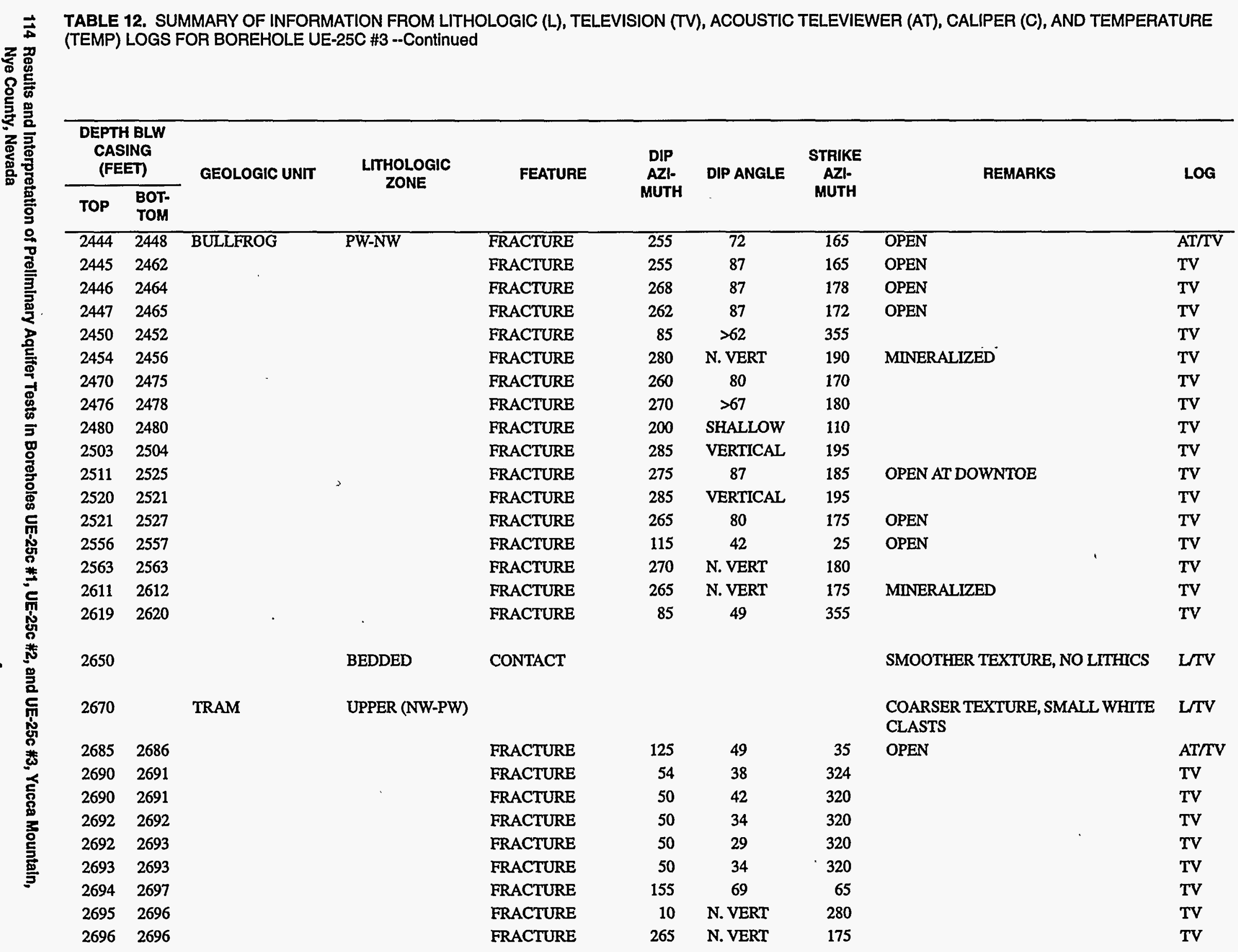


TABLE 12. SUMMARY OF INFORMATION FROM LITHOLOGIC (L), TELEVISION (TV), ACOUSTIC TELEVIEWER (AT), CALIPER (C), AND TEMPERATURE (TEMP) LOGS FOR BOREHOLE UE-25C \#3 -Continued

\begin{tabular}{|c|c|c|c|c|c|c|c|c|c|}
\hline \multicolumn{2}{|c|}{$\begin{array}{l}\text { DEPTH BLW } \\
\text { CASING } \\
\text { (FEET) }\end{array}$} & \multirow{2}{*}{ GEOLOGIC UNIT } & \multirow{2}{*}{$\begin{array}{l}\text { LTHOLOGIC } \\
\text { ZONE }\end{array}$} & \multirow{2}{*}{ FEATURE } & \multirow{2}{*}{$\begin{array}{c}\text { DIP } \\
\text { AZF- } \\
\text { MUTH }\end{array}$} & \multirow{2}{*}{ DIP ANGLE } & \multirow{2}{*}{$\begin{array}{c}\text { STRIKE } \\
\text { AZI- } \\
\text { MUTH }\end{array}$} & \multirow{2}{*}{ REMARKS } & \multirow{2}{*}{ LOG } \\
\hline TOP & $\begin{array}{l}\text { BOT- } \\
\text { TOM }\end{array}$ & & & & & & & & \\
\hline 2702 & 2702 & & & FRACTURE & 355 & 39 & 265 & & TV \\
\hline 2703 & 2704 & & & FRACTURE & 125 & 24 & 35 & OPEN & AT/TV \\
\hline 2704 & 2704 & & & FRACTURE & 305 & 19 & 215 & & TV \\
\hline 2711 & 2713 & & & FRACTURE & 55 & 67 & 325 & & TV \\
\hline 2713 & 2713 & & & FRACTURE & 350 & 38 & 260 & & TV \\
\hline 2720 & 2721 & & & FRACTURE & 350 & 42 & 260 & & TV \\
\hline 2728 & 2730 & & & FRACTURE & 100 & 55 & 10 & & TV \\
\hline 2734 & 2735 & & & FRACTURE & 340 & 34 & 250 & & TV \\
\hline 2735 & 2735 & & & FRACTURE & 340 & 24 & 250 & & TV \\
\hline 2747 & 2748 & & & FRACTURE & 85 & 24 & 355 & & TV \\
\hline 2749 & 2749 & & & FRACTURE & 90 & 29 & 0 & MINERALIZED & TV \\
\hline 2750 & 2751 & & & FRACTURE & 90 & 33 & 0 & & TV \\
\hline 2752 & 2752 & & & FRACTURE & 280 & 34 & 190 & & TV \\
\hline 2753 & 2754 & & & FRACTURE & 82 & 51 & 352 & & $/ \mathrm{TV}$ \\
\hline 2753 & 2754 & & & FRACTURE & 325 & 38 & 235 & & TV \\
\hline 2753 & 2754 & & & FRACTURE & 98 & 45 & 8 & . & TV \\
\hline 2755 & 2755 & & & FRACTURE & 315 & 34 & 225 & & TV \\
\hline 2758 & 2759 & & & FRACTURE & 315 & 38 & 225 & & TV \\
\hline 2760 & 2761 & & & FRACTURE & 90 & 42 & 0 & & TV \\
\hline 2760 & 2761 & & & FRACTURE & 90 & 25 & 0 & & TV \\
\hline 2762 & 2763 & & & FRACTURE & 335 & N. VERT & 245 & & TV \\
\hline
\end{tabular}


$\vec{*}$ TABLE 12. SUMMARY OF INFORMATION FROM LITHOLOGIC (L), TELEVISION (TV), ACOUSTIC TELEVIEWER (AT), CALIPER (C), AND TEMPERATURE

(TEMP) LOGS FOR BOREHOLE UE-25C \#3 --Continued

\begin{tabular}{|c|c|c|c|c|c|c|c|c|c|}
\hline \multicolumn{2}{|c|}{$\begin{array}{l}\text { DEPTH BLW } \\
\text { CASING } \\
\text { (FEET) }\end{array}$} & \multirow[t]{2}{*}{ GEOLOGIC UNIT } & \multirow{2}{*}{$\begin{array}{l}\text { LTHOLOGIC } \\
\text { ZONE }\end{array}$} & \multirow[t]{2}{*}{ FEATURE } & \multirow{2}{*}{$\begin{array}{l}\text { DIP } \\
\text { AZl- } \\
\text { MUTH }\end{array}$} & \multirow[t]{2}{*}{ DIP ANGLE } & \multirow{2}{*}{$\begin{array}{c}\text { STRIKE } \\
\text { AZI- } \\
\text { MUTH }\end{array}$} & \multirow[t]{2}{*}{ REMARKS } & \multirow[t]{2}{*}{ LOG } \\
\hline TOP & $\begin{array}{l}\text { BOT- } \\
\text { TOM }\end{array}$ & & & & & & & & \\
\hline 2763 & 2763 & TRAM & UPPER (NW-PW) & FRACTURE & 315 & 19 & 225 & & TV \\
\hline 2763 & 2765 & & & FRACTURE & 95 & 64 & 5 & & TV \\
\hline 2764 & 2765 & & & FRACTURE & 90 & 60 & 0 & & TV \\
\hline 2764 & 2765 & & & FRACTURE & 270 & N. VERT & 180 & & TV \\
\hline 2765 & 2767 & & & FRACTURE & 170 & 61 & 80 & & TV \\
\hline 2766 & 2767 & & & FRACTURE & 90 & 54 & 0 & & $\mathrm{TV}$ \\
\hline 2770 & 2772 & & & FRACTURE & 85 & 72 & 355 & & TV \\
\hline 2771 & 2773 & & & FRACTURE & 90 & 60 & 0 & & TV \\
\hline 2772 & 2773 & & & FRACTURE & 92 & 65 & 2 & & $\mathrm{TV}$ \\
\hline 2773 & 2774 & & & FRACTURE & 90 & 60 & 0 & & TV \\
\hline 2774 & 2774 & & & FRACTURE & 290 & N. VERT & 200 & . & $\mathrm{TV}$ \\
\hline 2776 & 2777 & & & FRACTURE & 95 & 65 & 5 & & TV \\
\hline 2777 & 2778 & & & FRACTURE & 90 & $>49$ & 0 & & $\mathrm{TV}$ \\
\hline 2777 & 2778 & & & FRACTURE & 95 & $>56$ & 5 & & TV \\
\hline 2777 & 2778 & & & FRACTURE & 280 & 61 & 190 & & TV \\
\hline 2777 & 2778 & & & FRACTURE & 305 & STEEP & 215 & & TV \\
\hline 2782 & 2783 & & & FRACTURE & 85 & 53 & 355 & & TV \\
\hline 2783 & 2784 & & & FRACTURE & 92 & 64 & 2 & & $\mathrm{TV}$ \\
\hline 2785 & 2788 & & . & FRACTURE & 110 & 70 & 20 & & $\mathrm{TV}$ \\
\hline 2787 & 2788 & & & FRACTURE & 85 & $>59$ & 355 & . & TV \\
\hline 2790 & 2792 & & & FRACTURE & 280 & 59 & 190 & & TV \\
\hline 2791 & 2793 & & & FRACTURE & 82 & 65 & 352 & & TV \\
\hline 2793 & 2794 & & & FRACTURE & 85 & $>51$ & 355 & & TV \\
\hline 2793 & 2795 & & & FRACTURE & 270 & 62 & 180 & & TV \\
\hline 2796 & 2798 & & & FRACTURE & 80 & $>58$ & 350 & & TV \\
\hline 2798 & 2799 & & & FRACTURE & 330 & SHALLOW & 240 & MINERALIZED & TV \\
\hline 2801 & 2801 & - & & FRACTURE & 195 & N. VERT & 105 & & TV \\
\hline 2803 & 2804 & & & FRACTURE & 345 & N. VERT & 255 & $\begin{array}{l}\text { BOREHOLE WALLS SHATTERED } \\
\text { 2803-2804 }\end{array}$ & TV \\
\hline 2803 & 2804 & & & FRACTURE & 345 & N. VERT & 255 & & TV \\
\hline 2803 & 2804 & & & FRACTURE & 92 & 56 & 2 & & $\mathrm{TV}$ \\
\hline
\end{tabular}


TABLE 12. SUMMARY OF INFORMATION FROM LITHOLOGIC (L), TELEVISION (TV), ACOUSTIC TELEVIEWER (AT), CALIPER (C), AND TEMPERATURE (TEMP) LOGS FOR BOREHOLE UE-25C \#3 --Continued

\begin{tabular}{|c|c|c|c|c|c|c|c|c|c|}
\hline \multicolumn{2}{|c|}{$\begin{array}{l}\text { DEPTH BLW } \\
\text { CASING } \\
\text { (FEET) }\end{array}$} & \multirow[t]{2}{*}{ GEOLOGIC UNIT } & \multirow{2}{*}{$\begin{array}{l}\text { LITHOLOGIC } \\
\text { ZONE }\end{array}$} & \multirow[t]{2}{*}{ FEATURE } & \multirow{2}{*}{$\begin{array}{c}\text { DIP } \\
\text { AZI- } \\
\text { MUTH }\end{array}$} & \multirow[t]{2}{*}{ DIP ANGLE } & \multirow{2}{*}{$\begin{array}{c}\text { STRIKE } \\
\text { AZI- } \\
\text { MUTH }\end{array}$} & \multirow[t]{2}{*}{ REMARKS } & \multirow[t]{2}{*}{ LOG } \\
\hline TOP & $\begin{array}{l}\text { BOT- } \\
\text { TOM }\end{array}$ & & & & & & & & \\
\hline 2804 & 2804 & & & FRACTURE & 270 & N. VERT & 180 & & TV \\
\hline 2804 & 2805 & & TUFF BRECCIA & CONTACT & w & 51 & $\mathbf{s}$ & $\begin{array}{l}\text { TEXTURE BECOMES VERY COARSE } \\
\text { (PATCHY) }\end{array}$ & TV \\
\hline 2807 & 2808 & & & FRACTURE & 90 & SHALLOW & $\mathbf{0}$ & $\begin{array}{l}\text { PAINTBRUSH CN? FAULT ZONE } \\
2807-2828 \text { ON LITH LOG }\end{array}$ & TV \\
\hline 2811 & 2811 & & & FRACTURE & 170 & SHALLOW & 80 & & TV \\
\hline 2814 & 2814 & & & FRACTURE & 265 & STEEP & 175 & & $\mathrm{TV}$ \\
\hline 2814 & 2814 & & & FRACTURE & 90 & SHALLOW & 0 & & TV \\
\hline 2814 & 2816 & & & FRACTURE & 80 & 65 & 350 & & TV \\
\hline 2819 & 2820 & & & FRACTURE & 75 & STEEP & 345 & & TV \\
\hline 2825 & 2825 & & & FRACTURE & 335 & N. VERT & 245 & & TV \\
\hline 2825 & 2825 & & & FRACTURE & 60 & SHALLOW & 330 & & TV \\
\hline 2825 & 2826 & & & FRACTURE & 307 & 55 & 217 & & $\mathrm{AT}$ \\
\hline 2827 & 2828 & & & FRACTURE & 270 & 58 & 180 & & AT \\
\hline 2830 & 2830 & & & FRACTURE & 50 & 43 & 320 & MINERALIZED & $\mathrm{TV}$ \\
\hline 2830 & 2831 & & & FRACTURE & 240 & STEEP & 150 & & TV \\
\hline 2830 & 2832 & TRAM & TUFF BRECCIA & FRACTURE & 300 & 62 & 210 & & $\mathrm{AT}$ \\
\hline 2831 & 2832 & & & FRACTURE & 65 & STEEP & 335 & & TV \\
\hline 2831 & 2838 & & & FRACTURE & 285 & $>78$ & 195 & $\begin{array}{l}\text { CAVERNOUS; HOLE FOLLOWS } \\
\text { FRACTURE }\end{array}$ & TV \\
\hline 2839 & 2841 & & & FRACTURE & 305 & 66 & 215 & BOREHOLE WALLS SHATTERED & $\mathrm{AT} / \mathrm{TV}$ \\
\hline 2843 & 2843 & & & FRACTURE & 75 & 34 & 345 & $\begin{array}{l}\text { MINERALIZED; HOLE ENLARGED } \\
\text { BY FRACTURES } 2839-2872\end{array}$ & TV \\
\hline
\end{tabular}


TABLE 12. SUMMARY OF INFORMATION FROM LITHOLOGIC (L), TELEVISION (TV), ACOUSTIC TELEVIEWER (AT), CALIPER (C), AND TEMPERATURE (TEMP) LOGS FOR BOREHOLE UE-25C \#3 --Continued

\begin{tabular}{|c|c|c|c|c|c|c|c|c|c|}
\hline \multicolumn{2}{|c|}{$\begin{array}{l}\text { DEPTH BLW } \\
\text { CASING } \\
\text { (FEET) }\end{array}$} & \multirow{2}{*}{ GEOLOGIC UNIT } & \multirow{2}{*}{$\begin{array}{l}\text { LITHOLOGIC } \\
\text { ZONE }\end{array}$} & \multirow{2}{*}{ FEATURE } & \multirow{2}{*}{$\begin{array}{l}\text { DIP } \\
\text { AZI- } \\
\text { MUTH }\end{array}$} & \multirow{2}{*}{ DIP ANGLE } & \multirow{2}{*}{$\begin{array}{l}\text { STRIKE } \\
\text { AZI- } \\
\text { MUTH }\end{array}$} & \multirow{2}{*}{ REMARKS } & \multirow[t]{2}{*}{ LOG } \\
\hline TOP & $\begin{array}{l}\text { BOT- } \\
\text { TOM }\end{array}$ & & & & & & & & \\
\hline 2849 & 2849 & \multirow[t]{17}{*}{ TRAM } & \multirow[t]{30}{*}{ TUFF BRECCLA } & FRACTURE & 210 & SHALLOW & 120 & & TV \\
\hline 2849 & 2850 & & & FRACTURE & 10 & 37 & 280 & & TV \\
\hline 2849 & 2850 & & & FRACTURE & 95 & STEEP & 5 & & TV \\
\hline 2850 & 2851 & & & FRACTURE & 35 & 54 & 305 & $\begin{array}{l}\text { OPEN; ROCK VERY BRECCIATED } \\
2850-2877\end{array}$ & $T V$ \\
\hline 2865 & 2868 & & & FRACTURE & 265 & N. VERT & 175 & & TV \\
\hline 2869 & 2870 & & & FRACTURE & 265 & N. VERT & 175 & & TV \\
\hline 2871 & 2872 & & & FRACTURE & 78 & 49 & 348 & & TV \\
\hline 2872 & 2877 & & & FRACTURE & 270 & $>79$ & 180 & & TV \\
\hline 2880 & 2881 & & & FRACTURE & 122 & 56 & 32 & MINERALIZED & TV \\
\hline 2881 & 2881 & & & FRACTURE & 68 & 35 & 338 & MINERALIZED & TV \\
\hline 2881 & 2883 & & & FRACTURE & 120 & 63 & 30 & MINERALIZED & TV \\
\hline 2881 & 2882 & & & FRACTURE & 55 & 49 & 325 & MINERALIZED & TV \\
\hline 2884 & 2885 & & & FRACTURE & 65 & 49 & 335 & & TV \\
\hline 2884 & 2885 & & & FRACTURE & 47 & 49 & 317 & MINERALIZED & TV \\
\hline 2886 & 2886 & & & FRACTURE & 60 & 42 & 330 & & TV \\
\hline 2886 & 2887 & & & FRACTURE & 55 & 49 & 325 & & TV \\
\hline 2886 & 2887 & & & FRACTURE & 75 & 58 & 345 & & TV \\
\hline 2886 & 2887 & \multirow[t]{13}{*}{$\cdot$} & & FRACTURE & 65 & 45 & 335 & MINERALIZED & TV \\
\hline 2887 & 2888 & & & FRACTURE & 70 & 51 & 340 & MINERALIZED & TV. \\
\hline 2887 & 2888 & & & FRACTURE & 65 & 55 & 335 & MINERALIZED & TV \\
\hline 2888 & 2889 & & & FRACTURE & 45 & 51 & 315 & MINERALIZED & TV \\
\hline 2888 & 2889 & & & FRACTURE & 45 & 38 & 315 & MINERALIZED & TV \\
\hline 2888 & 2889 & & & FRACTURE & 45 & 38 & 315 & MINERALIZED & TV \\
\hline 2892 & 2893 & & & FRACTURE & 45 & 54 & 315 & MINERALIZED & TV \\
\hline 2892 & 2893 & & & FRACTURE & 45 & 54 & 315 & MINERALIZED & TV \\
\hline 2895 & 2896 & & & FRACTURE & 40 & 49 & 310 & MINERALIZED & TV \\
\hline 2895 & 2896 & & & FRACTURE & 40 & 58 & 310 & MINERALIZED & TV \\
\hline 2896 & 2897 & & & FRACTURE & 40 & 53 & 310 & MINERALIZED & TV \\
\hline 2898 & 2899 & & & FRACTURE & 65 & 51 & 335 & MINERALIZED & TV \\
\hline 2899 & 2900 & & & FRACTURE & 60 & 52 & 330 & MINERALIZED & TV \\
\hline
\end{tabular}


TABLE 12. SUMMARY OF INFORMATION FROM LITHOLOGIC (L), TELEVISION (TV), ACOUSTIC TELEVIEWER (AT), CALIPER (C), AND TEMPERATURE (TEMP) LOGS FOR BOREHOLE UE-25C \#3 --Continued

\begin{tabular}{|c|c|c|c|c|c|c|c|c|c|}
\hline \multicolumn{2}{|c|}{$\begin{array}{l}\text { DEPTH BLW } \\
\text { CASING } \\
\text { (FEET) }\end{array}$} & \multirow[t]{2}{*}{ GEOLOGIC UNIT } & \multirow{2}{*}{$\begin{array}{l}\text { LITHOLOGIC } \\
\text { ZONE }\end{array}$} & \multirow[t]{2}{*}{ FEATURE } & \multirow{2}{*}{$\begin{array}{c}\text { DIP } \\
\text { AZL- } \\
\text { MUTH }\end{array}$} & \multirow[t]{2}{*}{ DIP ANGLE } & \multirow{2}{*}{$\begin{array}{c}\text { STRIKE } \\
\text { AZI- } \\
\text { MUTH }\end{array}$} & \multirow[t]{2}{*}{ REMARKS } & \multirow[t]{2}{*}{ LOG } \\
\hline TOP & $\begin{array}{l}\text { BOT- } \\
\text { TOM }\end{array}$ & & & & & & & & \\
\hline 2899 & 2900 & TRAM & TUFF BRECCIA & FRACTURE & 65 & STEEP & 335 & & $\overline{T V}$ \\
\hline 2900 & 2901 & & & FRACTURE & 85 & 52 & 355 & & TV \\
\hline 2900 & 2901 & & & FRACTURE & 95 & 46 & 5 & MINERALIZED & TV \\
\hline 2902 & 2904 & & & FRACTURE & 80 & 52 & 350 & & TV \\
\hline 2903 & 2903 & & & FRACTURE & 5 & SHALLOW & 275 & & TV \\
\hline 2904 & 2905 & & & FRACTURE & 80 & 52 & 350 & & TV \\
\hline 2904 & 2905 & & & FRACTURE & 45 & 56 & 315 & & TV \\
\hline 2906 & 2907 & & & FRACTURE & 0 & 25 & 270 & & TV \\
\hline 2906 & 2907 & & & FRACTURE & 90 & 30 & 0 & & TV \\
\hline 2907 & 2908 & & & FRACTURE & 70 & 42 & 340 & & TV \\
\hline 2907 & 2907 & & & FRACTURE & 65 & 30 & 335 & & TV \\
\hline 2908 & 2908 & & & FRACTURE & 40 & 30 & 310 & & TV \\
\hline 2908 & 2908 & & & FRACTURE & 175 & SHALLOW & 85 & & TV \\
\hline 2908 & 2909 & & & FRACTURE & 40 & 35 & 310 & & TV \\
\hline 2909 & 2909 & & & FRACTURE & 40 & 43 & 310 & & TV \\
\hline 2910 & 2910 & & & FRACTURE & 155 & 43 & 65 & & TV \\
\hline 2923 & 2924 & & & FRACTURE & 112 & 46 & 22 & & TV \\
\hline 2926 & 2928 & & & FRACTURE & 5 & 67 & 275 & & TV \\
\hline 2932 & 2933 & & & FRACTURE & 260 & VERTICAL & 170 & & TV \\
\hline 2937 & 2940 & & & FRACTURE & 85 & $>76$ & 355 & & TV \\
\hline 2940 & 2942 & & & FRACTURE & 95 & 62 & 5 & & TV \\
\hline 2944 & 2945 & & & FRACTURE & 90 & 54 & 0 & * & TV \\
\hline 2950 & 2954 & & & CABLE & & & & RESTING ON BOTTOM OF HOLE & TV \\
\hline 2954 & & & & BOTTOM & & & & $\begin{array}{l}\text { HOLE CAVED TO ORIGINAL TD } \\
\text { AT } 3000\end{array}$ & TV/C \\
\hline
\end{tabular}


The distribution code for this report is UC-814. 